Prepared in cooperation with the City of Independence, Missouri, Water Pollution Control Department

\title{
Hydrological, Water-Quality, and Ecological Data for Streams in Independence, Missouri, June 2005 through September 2013
}

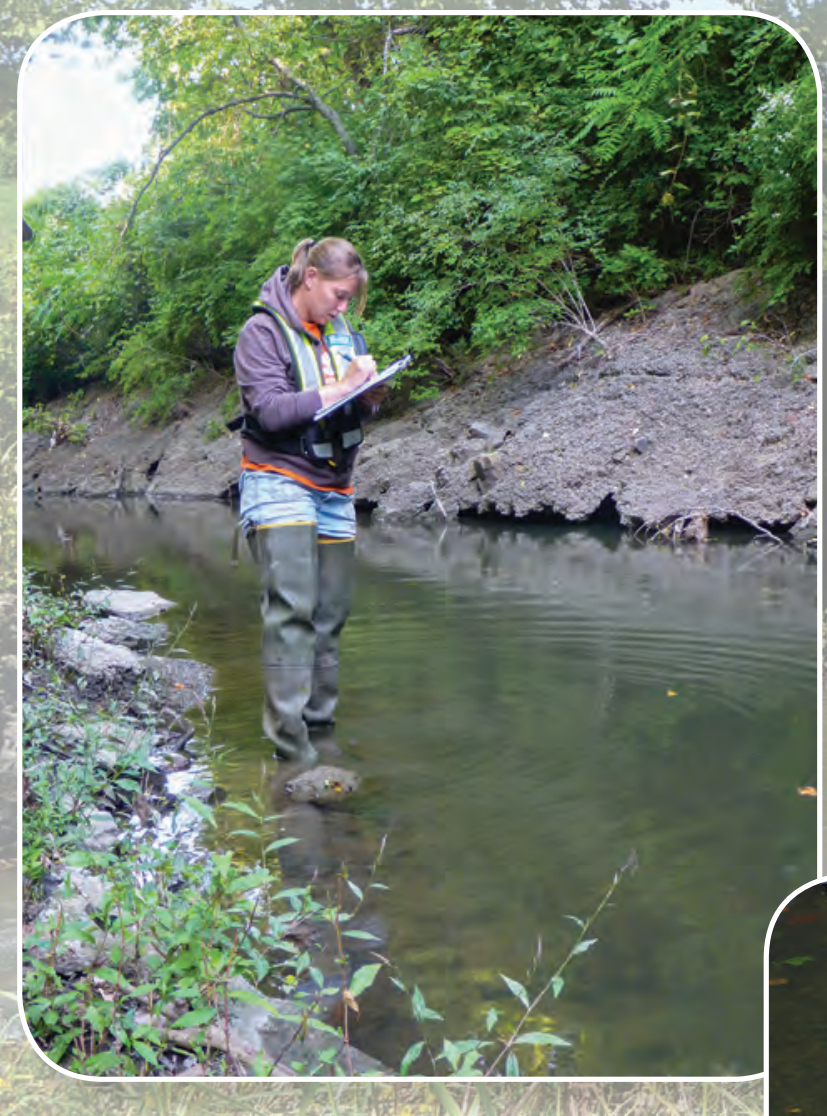

Data Series 915

U.S. Department of the Interior U.S. Geological Survey

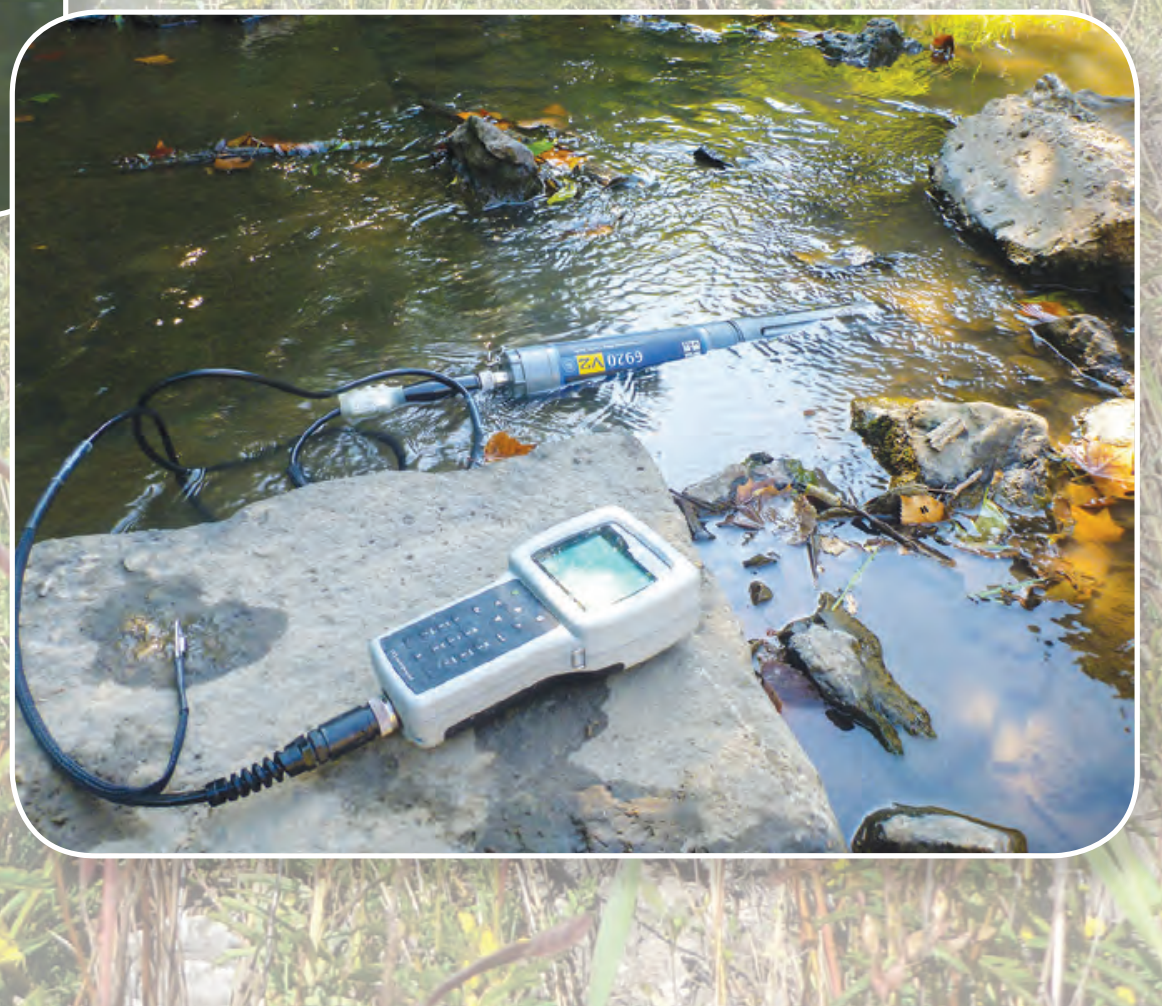




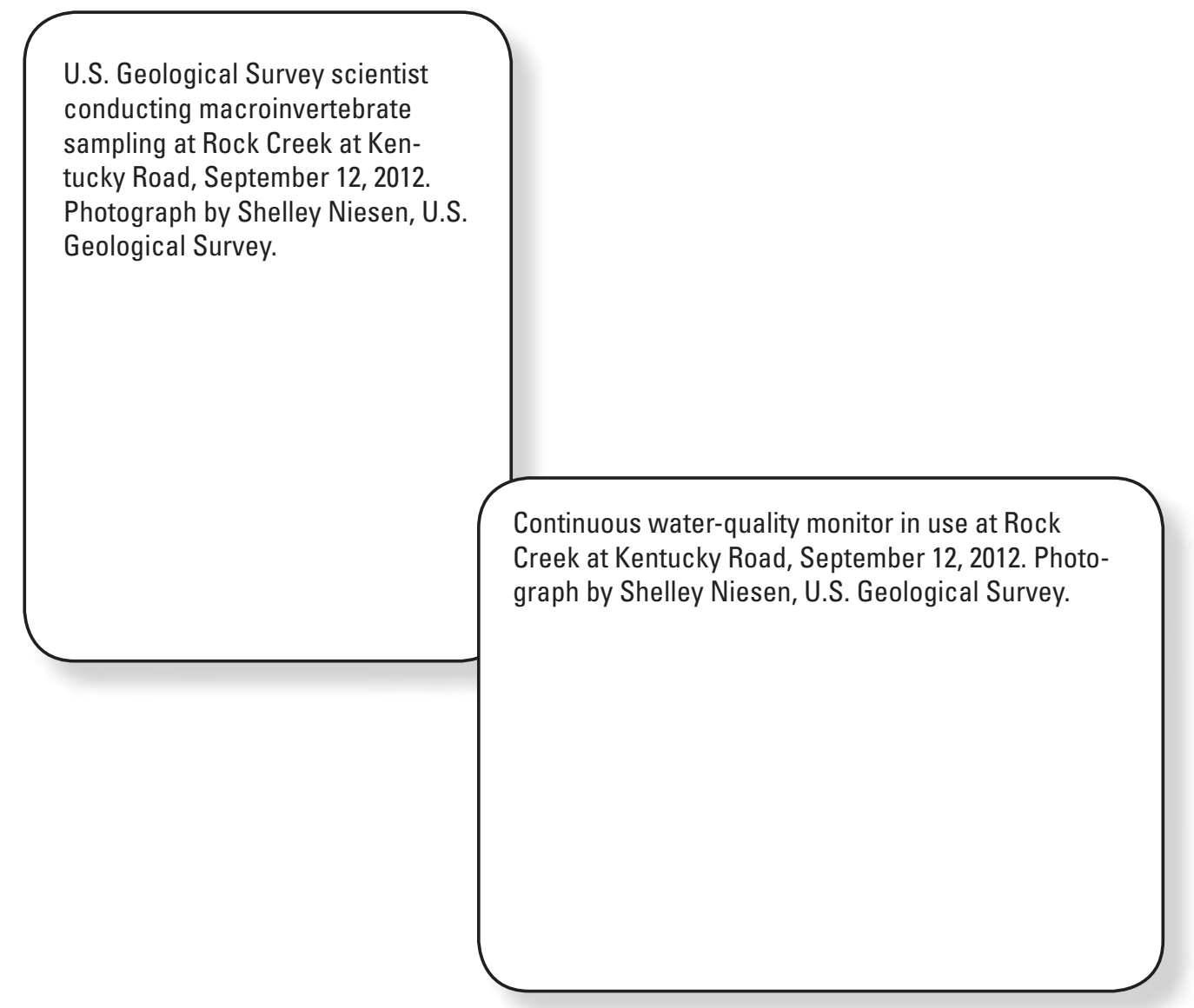

Front cover background photograph: Little Blue River at Lee's

Summit Road, September 11, 2012. Photograph by Heather Krempa, U.S. Geological Survey.

Back cover background photograph: Little Blue River at Lee's Summit Road, September 11, 2012. Photograph by Heather Krempa, U.S. Geological Survey. 


\section{Hydrological, Water-Quality, and Ecological Data for Streams in Independence, Missouri, June 2005 through September 2013}

By Shelley L. Niesen and Eric D. Christensen

Prepared in cooperation with the City of Independence, Missouri, Water Pollution Control Department

Data Series 915 


\title{
U.S. Department of the Interior SALLY JEWELL, Secretary
}

\section{U.S. Geological Survey Suzette M. Kimball, Acting Director}

\author{
U.S. Geological Survey, Reston, Virginia: 2015
}

For more information on the USGS - the Federal source for science about the Earth, its natural and living resources, natural hazards, and the environment, visit http://Www.usgs.gov or call 1-888-ASK-USGS.

For an overview of USGS information products, including maps, imagery, and publications, visit http://WwW.usgs.gov/pubprod

To order this and other USGS information products, visit http://store.usgs.gov

Any use of trade, firm, or product names is for descriptive purposes only and does not imply endorsement by the U.S. Government.

Although this information product, for the most part, is in the public domain, it also may contain copyrighted materials as noted in the text. Permission to reproduce copyrighted items must be secured from the copyright owner.

Suggested citation:

Niesen, S.L., and Christensen, E.D., 2015, Hydrological, water-quality, and ecological data for streams in Independence, Missouri, June 2005 through September 2013: U.S. Geological Survey Data Series 915, 80 p., http://dx.doi. org/10.3133/ds915

ISSN: 2327-638X (online) 


\section{Acknowledgments}

The authors would like to express their appreciation to Dick Champion, Director; Dorris Bender; and Larry White of the Independence Water Pollution Control Department for their ongoing cooperative support of the U.S. Geological Survey studies in Independence, Missouri. Assistance from Independence Water Pollution Control employees was essential for completion of dry-weather screening. Dr. Andrew Carson of the University of Missouri, Rebecca Bushon, Erin Stelzer, and Amie Brady of the U.S. Geological Survey Ohio Water Microbiology Laboratory provided helpful reviews and technical advice regarding microbial source tracking methods and results. 


\section{Contents}

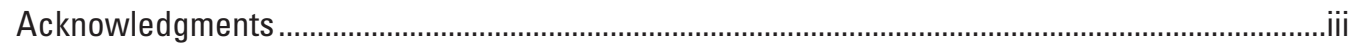

Conversion Factors .................................................................................................................

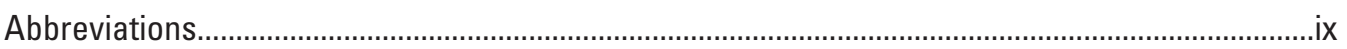

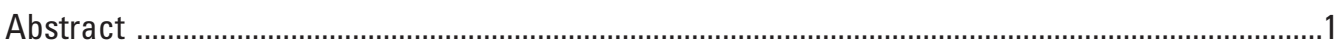

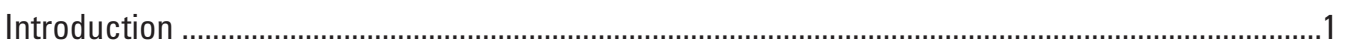

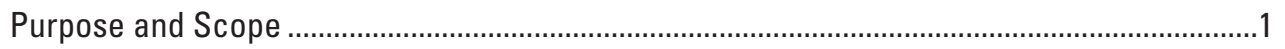

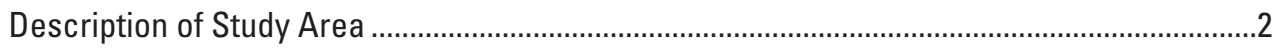

Previous Investigations.................................................................................................

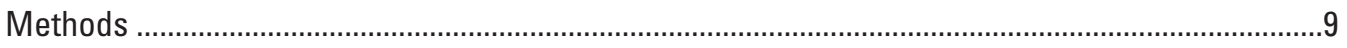

Streamflow and Continuous Water-Quality Monitoring ..............................................................

Water-Quality Sample Collection and Procedures ...............................................................

Laboratory and Data Analysis ......................................................................................13

Quality Control and Quality Assurance ..............................................................................

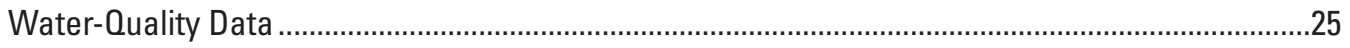

Continuous Streamflow and Water-Quality Measurements ................................................25

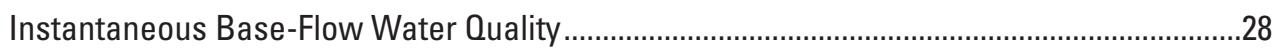

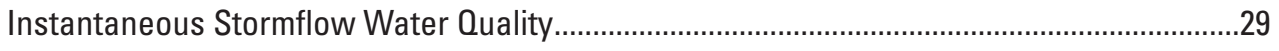

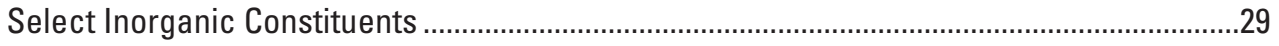

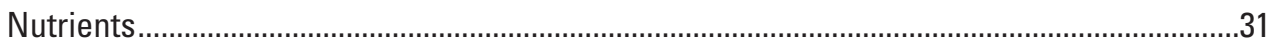

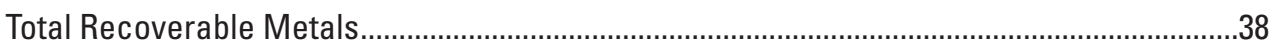

Common Organic Micro-Constituents and Pesticides in Streambed Sediment and Surface

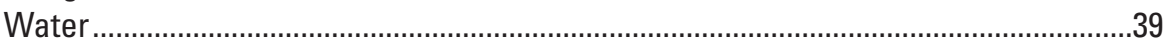

Fecal Indicator Bacteria, Microbial Source Tracking, and Suspended Sediment ................40

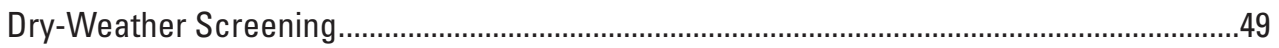

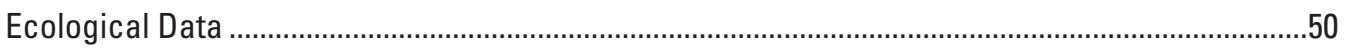

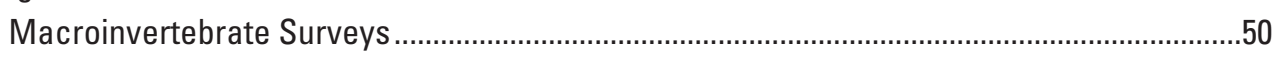

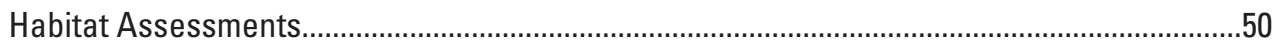

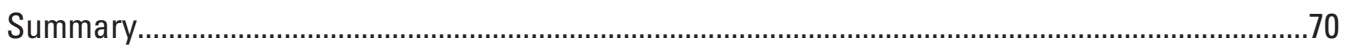

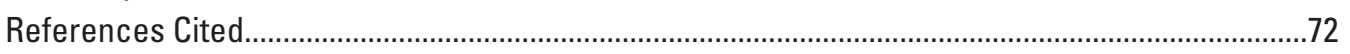

Appendixes 1 and 2

\section{Figures}

1. Map showing the Little Blue River Basin, sampling sites, study area location, and political boundaries for Independence, Missouri, and surrounding cities.

2. Map showing land use/land cover in the Little Blue River Basin and adjacent basins within Independence, Missouri.

3. Graphs showing average monthly temperatures and precipitation at Independence, Missouri, for June 2005 through September 2013 compared to the 27-year average from October 1986 through September 2013

4. Graph showng annual precipitation for Independence, Missouri, water years (October 1 through September 30) 2005 through 2013. 
5. Photograph showing continuous water-quality monitor with (clockwise from upper left) turbidity, optical dissolved oxygen, $\mathrm{pH}$, and combined specific conductance and

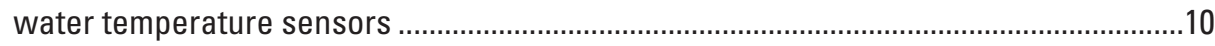

6. Graphs showing quality-assurance data for nutrients and select constituents in field replicate or laboratory duplicate sample pairs...

7. Graphs showing quality-assurance data for fecal indicator bacteria in field replicate or laboratory duplicate sample pairs

8. Graphs showing quality-assurance data for dry-weather screening samples in field replicate or laboratory duplicate sample pairs

9. Graph showing monthly average streamflow by site, June 2005 through September 2013

10. Graph showing percentage deviations from the 27-year monthly average streamflow at Little Blue River near Lake City, Missouri, compared with the 27-year monthly average precipitation measured and recorded at Independence, Missouri, June 2005 through September 2013.

11. Boxplots showing computed daily average values of dissolved oxygen, $\mathrm{pH}$, specific conductance, water temperature, and turbidity at continuous water-quality monitoring sites in Independence, Missouri.

12. Graphs showing frequency of exceedance of daily average dissolved oxygen, $\mathrm{pH}$, specific conductance, water temperature, and turbidity at sampling sites equipped with continuous water-quality monitors in Independence, Missouri. Period of record at individual sites varies

13. Maps showing dry-weather screening sampling sites and locations of constituent detections for selected stream basins in Independence, Missouri, water years 2006 through 2013

14. Boxplots showing dry-weather screening constituent concentrations in streams in Independence, Missouri, water years 2006 through 2013.

15. Boxplots showing macroinvertebrate taxa and individuals enumerated in samples from all sites, March 2007 through March 2013.

\section{Tables}

1. Land use in the City of Independence and basins wholly or partially within Independence city boundaries..

2. Sampling sites in Independence, Missouri, biologic sampling reference sites, and type of hydrologic, water-quality, and ecologic data collected, June 2005 through September 2013.

3. Criteria for aquatic-life support categories for riffle habitats for the Missouri tributaries between the Blue and Lamine Rivers ecological drainage unit

4. Summary of quality-control (replicate and duplicate) sample results for selected constituents in base-flow and stormflow water-quality samples at all Independence sites, June 2006 through September 2013

5. Summary of detections of selected water-quality constituents and common organic micro-constituents in blank water samples at all Independence sites, June 2005 through September 2013.

6. Average blank sample concentrations for microbial source tracking samples by initial sample collection date and batch processing data group

7. Microbial source tracking replicate sample pairs 
8. Macroinvertebrate taxonomy, revised taxa names, and pollution tolerance values for taxa identified in samples, March 2007 through March 2013.

9. Summary of physical properties, nutrients, fecal indicator bacteria, and selected inorganic-constituent concentrations in base-flow samples by site, June 2005 through September 2013.

10. Summary of physical properties, nutrients, fecal indicator bacteria, and selected inorganic constituent concentrations in stormflow samples by site, June 2005 through September 2013.

11. Regression models for estimating annual loads, flow-weighted concentrations, and densities of selected sampled water-quality constituents.

12. Categories of common organic micro-constituents detected in urban streams

13. Summary of constituent concentrations by category of total common organic micro-constituents by site in base-flow samples, June 2006 through September 2013

14. Summary of constituent concentrations by category of total common organic micro-constituents by site in stormflow samples, June 2005 through September 2013

15. Pesticide constituents analyzed in streambed sediment and surface-water samples

16. Summary of selected pesticides detected in streambed sediment samples during base flow at all Independence sites, July 2010 through July 2013

17. Presumptive host sources of Escherichia coli in samples collected May through October 2007

18. Microbial source tracking marker concentrations for human and animal fecal source samples

19. Microbial source tracking samples by site, season, and streamflow condition ......... Link

20. Summary of dry-weather screening constituent detections in streams in Independence, Missouri, water years 2006 through 2013

21. Macroinvertebrate taxa and individuals enumerated in samples from all sites, March 2007 through March 2013

22. Habitat scores, dissolved oxygen, $\mathrm{pH}$, specific conductance, water temperature, macroinvertebrate metrics used in the stream condition index, and aquatic-life support status for samples collected March 2007 through March 2013

Appendix 1. Base-flow water-quality sample results for selected physical and chemical properties and constituents, June 2006 through September 2013.

Appendix 2. Stormflow water-quality sample results for selected physical and chemical properties and constituents, June 2005 through September 2013 


\section{Conversion Factors}

\begin{tabular}{|c|c|c|}
\hline Multiply & By & To obtain \\
\hline \multicolumn{3}{|c|}{ Length } \\
\hline inch (in.) & 2.54 & centimeter $(\mathrm{cm})$ \\
\hline mile (mi) & 1.609 & kilometer $(\mathrm{km})$ \\
\hline \multicolumn{3}{|c|}{ Area } \\
\hline square mile $\left(\mathrm{mi}^{2}\right)$ & 2.590 & square kilometer $\left(\mathrm{km}^{2}\right)$ \\
\hline \multicolumn{3}{|c|}{ Volume } \\
\hline cubic foot $\left(\mathrm{ft}^{3}\right)$ & 0.02832 & cubic meter $\left(\mathrm{m}^{3}\right)$ \\
\hline \multicolumn{3}{|c|}{ Flow rate } \\
\hline cubic foot per second $\left(\mathrm{ft}^{3} / \mathrm{s}\right)$ & 0.02832 & cubic meter per second $\left(\mathrm{m}^{3} / \mathrm{s}\right)$ \\
\hline \multicolumn{3}{|l|}{ SI to Inch/Pound } \\
\hline Multiply & By & To obtain \\
\hline \multicolumn{3}{|c|}{ Length } \\
\hline micron $(\mu \mathrm{m})$ & 0.0000394 & inch (in.) \\
\hline centimeter $(\mathrm{cm})$ & 0.3937 & inch (in.) \\
\hline meter $(\mathrm{m})$ & 3.281 & foot $(\mathrm{ft})$ \\
\hline kilometer $(\mathrm{km})$ & 0.6214 & mile (mi) \\
\hline \multicolumn{3}{|c|}{ Area } \\
\hline square kilometer $\left(\mathrm{km}^{2}\right)$ & 247.1 & acre \\
\hline square kilometer $\left(\mathrm{km}^{2}\right)$ & 0.3861 & square mile $\left(\mathrm{mi}^{2}\right)$ \\
\hline \multicolumn{3}{|c|}{ Volume } \\
\hline milliliter (mL) & 0.0338 & ounce, fluid (oz) \\
\hline liter $(\mathrm{L})$ & 0.2642 & gallon (gal) \\
\hline cubic meter $\left(\mathrm{m}^{3}\right)$ & 35.31 & cubic foot $\left(\mathrm{ft}^{3}\right)$ \\
\hline \multicolumn{3}{|c|}{ Flow rate } \\
\hline cubic meter per second $\left(\mathrm{m}^{3} / \mathrm{s}\right)$ & 35.31 & cubic foot per second $\left(\mathrm{ft}^{3} / \mathrm{s}\right)$ \\
\hline \multicolumn{3}{|c|}{ Mass } \\
\hline $\operatorname{gram}(\mathrm{g})$ & 0.03527 & ounce, avoirdupois (oz) \\
\hline kilogram (kg) & 2.205 & pound avoirdupois (lb) \\
\hline megagram (Mg) & 1.102 & ton, short $(2,000 \mathrm{lb})$ \\
\hline
\end{tabular}


Temperature in degrees Celsius $\left({ }^{\circ} \mathrm{C}\right)$ may be converted to degrees Fahrenheit $\left({ }^{\circ} \mathrm{F}\right)$ as follows: ${ }^{\circ} \mathrm{F}=\left(1.8 x^{\circ} \mathrm{C}\right)+32$

Temperature in degrees Fahrenheit $\left({ }^{\circ} \mathrm{F}\right)$ may be converted to degrees Celsius $\left({ }^{\circ} \mathrm{C}\right)$ as follows: ${ }^{\circ} \mathrm{C}=\left({ }^{\circ} \mathrm{F}-32\right) / 1.8$

A water year is the 12-month period from October 1 through September 30 of the following year.

Vertical coordinate information is referenced to the North American Vertical Datum of 1988 (NAVD 88)

Horizontal coordinate information is referenced to the North American Datum of 1983 (NAD 83).

Specific conductance is given in microsiemens per centimeter at 25 degrees Celsius $(\mu \mathrm{S} / \mathrm{cm}$ at $\left.25^{\circ} \mathrm{C}\right)$.

Concentrations of chemical constituents in water are given either in milligrams per liter (mg/L) or micrograms per liter $(\mu \mathrm{g} / \mathrm{L})$. 


\section{Abbreviations}

\begin{tabular}{|c|c|}
\hline ABS & alkyl benzene sulfonate \\
\hline AllBac & general fecal contamination marker \\
\hline ALS & aquatic-life support \\
\hline$A Q L$ & Protection of aquatic life \\
\hline BacCan & dog-associated marker \\
\hline bdl & below detection limit \\
\hline BMP & best management practice \\
\hline BoBac & ruminant-associated marker \\
\hline $\mathrm{BOD}_{5}$ & 5-day biochemical oxygen demand \\
\hline COD & chemical oxygen demand \\
\hline $\mathrm{col}$ & colonies \\
\hline CWOM & continuous water-quality monitor \\
\hline CY & calendar year \\
\hline DEET & N,N-diethyl-meta-toluamide \\
\hline DNA & deoxyribonucleic acid \\
\hline dnq & detected not quantified \\
\hline E. coli & Escherichia coli \\
\hline EDL & estimated detection limit \\
\hline EPA & U.S. Environmental Protection Agency \\
\hline EPT & Ephemeroptera plus Plecoptera plus Trichoptera \\
\hline EPTR & Ephemeroptera plus Plecoptera plus Trichoptera richness \\
\hline FIB & fecal indicator bacteria \\
\hline GPS & global positioning system \\
\hline IDAS & Invertebrate Data Analysis System \\
\hline ITIS & Integrated Taxonomic Information System \\
\hline LAS & linear alkylate sulfonate \\
\hline LoD & level of detection \\
\hline LoO & level of quantification \\
\hline LRL & laboratory reporting level \\
\hline LT-MDL & long term method detection limit \\
\hline $\mathrm{MBI}$ & Macroinvertebrate Biotic Index \\
\hline MDL & method detection limit \\
\hline MDNR & Missouri Department of Natural Resources \\
\hline MPN & most probable number \\
\hline MRL & minimum reporting level \\
\hline MS4 & municipal separate storm sewer system \\
\hline $\mathrm{MSCl}$ & Missouri stream condition index \\
\hline MST & microbial source tracking \\
\hline N & nitrogen \\
\hline
\end{tabular}




\begin{tabular}{|c|c|}
\hline $\mathrm{NH}_{3}$ & ammonia \\
\hline $\mathrm{NO}_{2}$ & nitrite \\
\hline $\mathrm{NO}_{3}$ & nitrate \\
\hline NOAA & National Oceanic and Atmospheric Association \\
\hline NPDES & National Pollution Discharge Elimination System \\
\hline NTU & nephelometric turbidity units \\
\hline NURP & Nationwide Urban Runoff Program \\
\hline NWIS & National Water Information System \\
\hline NWOL & National Water Quality Laboratory \\
\hline NWS & National Weather Service \\
\hline OMC & organic micro-constituent \\
\hline OWML & Ohio Water Microbiology Laboratory \\
\hline $\mathrm{P}$ & phosphorus \\
\hline PAH & polyaromatic hydrocarbon \\
\hline ppm & parts per million \\
\hline PVC & polyvinyl chloride \\
\hline qHF183 & human-associated marker \\
\hline qPCR & quantitative polymerase chain reaction \\
\hline$R^{2}$ & coefficient of determination \\
\hline rep-PCR & repetitive extragenic palindromic polymerase chain reaction \\
\hline $\mathrm{RICH}$ & total taxa richness \\
\hline RTH & richest targeted habitat \\
\hline $\mathrm{SCl}$ & stream condition index \\
\hline SHANDIV & Shannon Diversity Index \\
\hline SSC & suspended sediment concentration \\
\hline SWMP & stormwater management program \\
\hline TDS & total dissolved solids \\
\hline USGS & U.S. Geological Survey \\
\hline WPC & Water Pollution Control \\
\hline WWTP & wastewater treatment plant \\
\hline WY & water year \\
\hline
\end{tabular}




\title{
Hydrological, Water-Quality, and Ecological Data for Streams in Independence, Missouri, June 2005 through September 2013
}

\author{
By Shelley L. Niesen and Eric D. Christensen
}

\section{Abstract}

Water-quality, hydrological, and ecological data collected from June 2005 through September 2013 from the Little Blue River and smaller streams within the City of Independence, Missouri, are presented in this report. These data were collected as a part of an ongoing cooperative study between the U.S. Geological Survey and the City of Independence Water Pollution Control Department to characterize the water quality and ecological condition of Independence streams. The quantities, sources of selected constituents, and processes affecting water quality and aquatic life were evaluated to determine the resulting ecological condition of streams within Independence. Data collected for this study fulfill the municipal separate sewer system permit requirements for the City of Independence and can be used to provide a baseline with which city managers can determine the effectiveness of current (2014) and future best management practices within Independence. Continuous streamflow and water-quality data, collected during base flow and stormflow, included physical and chemical properties, inorganic constituents, common organic microconstituents, pesticides in streambed sediment and surface water, fecal indicator bacteria and microbial source tracking data, and suspended sediment. Dissolved oxygen, $\mathrm{pH}$, specific conductance, water temperature, and turbidity data were measured continuously at seven sites within Independence. Base-flow and stormflow samples were collected at eight gaged and two ungaged sites. Fecal sources samples were collected for reference for microbial source tracking, and sewage influent samples were collected as additional source samples. Dry-weather screening was done on 11 basins within Independence to identify potential contaminant sources to the streams. Benthic macroinvertebrate community surveys and habitat assessments were done on 10 stream sites and 2 comparison sites outside the city. Sampling and laboratory procedures and quality-assurance and quality-control methods used in data collection for this study are described in this report.

\section{Introduction}

The U.S. Geological Survey (USGS) and the City of Independence, Missouri, Water Pollution Control (WPC) Department began a cooperative study in June 2005 to characterize and evaluate the water quality and ecological condition of streams within Independence. The quantities and sources of pollutants were determined to better understand the processes that affect water quality and its effect on aquatic life in Independence streams. Hydrological, water-quality, and ecological data were collected between June 2005 and September 2013 and compiled and summarized for this report. The data collected will assist Independence in fulfilling its National Pollution Discharge Elimination System (NPDES) permit requirements for the municipal separate storm sewer system (MS4). According to the Electronic Code of Federal Regulations (2013), an MS4 is a system of conveyances that include man-made channels, pipes, tunnels, and storm drains, as well as surface streets, catch basins, curbs, gutters, and ditches that discharge into waters of the United States. In order for Independence to meet the conditions for its MS4 permit and to design effective strategies to reduce contaminant discharges to streams, information about the source and nature of contaminants detected in receiving streams is needed. The data presented in this report can be used by Independence to evaluate differences between base-flow and stormflow water quality in its urban streams, implement its stormwater management program (SWMP), evaluate best management practices (BMPs), and establish a baseline by which the effectiveness of current (2014) and future BMPs can be measured.

\section{Purpose and Scope}

This report presents hydrological, water-quality, and ecological data collected by USGS from June 2005 through September 2013 as part of an ongoing cooperative study with the Independence WPC Department to characterize the waterquality and ecological condition of streams in Independence. Summary data presented in this report are based on data collected from June 2005 through December 2008 (Christensen 
and others, 2010) and data collected from January 2009 through September 2013. Continuous streamflow was measured at eight sites and dissolved oxygen, $\mathrm{pH}$, specific conductance, water temperature, and turbidity data were collected at seven sites in the study area equipped with streamgages and continuous water-quality monitors (CWQMs). Total dissolved solids ([TDS]; referred to in previous publications as dissolved residue on evaporation at 180 degrees Celsius $\left[{ }^{\circ} \mathrm{C}\right]$ ), selected major ions, nutrients, metals, common organic micro-constituents (OMCs), pesticides in streambed sediment and surface water, fecal indicator bacteria (FIB; Escherichia Coli [E. Coli], fecal coliform, total coliform), microbial source tracking (MST), and suspended sediment concentration (SSC) data for base-flow and stormflow samples are presented.

Estimated annual loads and flow-weighted concentrations of selected constituents are listed. Results for analyses of samples collected during dry-weather screening are summarized. Benthic macroinvertebrate community survey results and habitat assessments also are presented. Sampling, analytical, and quality-control and quality-assurance methods used in data collection and processing are described.

\section{Description of Study Area}

Independence is located to the east of Kansas City in Jackson County (fig.1). The study area covers 203 square kilometers $\left(\mathrm{km}^{2}\right)$ within the boundaries of the city limits of Independence. The population of Independence in 2012 was 117,270 (U.S. Census Bureau, 2014), yielding a population density of about 578 people per square kilometer. There were 53,834 housing units within Independence in 2010, an increase of 7.1 percent from 2006 (U.S. Census Bureau, 2014).

The streams in the twelve basins that cover most of Independence flow north to the Missouri River (fig. 1). About two-thirds of the city is drained by the Little Blue River and its tributaries. Of the total area of the Little Blue River Basin $\left(585 \mathrm{~km}^{2}\right.$, fig. 1$)$, about $168 \mathrm{~km}^{2}$, or roughly 29 percent, is within Independence. Upstream conditions in the Little Blue River Basin affect downstream hydrologic and water-quality conditions in the city.

Streamflow in the Little Blue River is affected by reservoirs at Longview Lake on the main stem of the Little Blue River, and Prairie Lee Lake, Lake Jacomo, and Blue Springs Lake on the East Fork of the Little Blue River (fig. 1). Blue Springs Lake and Longview Lake reservoirs are upstream from Independence on the Little Blue River and affect base flow. Low-flow releases from Longview Lake are maintained at a minimum of about seven cubic feet per second $\left(\mathrm{ft}^{3} / \mathrm{s}\right)$, but low-flow releases are not maintained for Blue Springs Lake. The dams on the East Fork of the Little Blue River were constructed in 1936 (Prairie Lee Lake; Heimann, 1995) and 1986 (Blue Springs Lake; Rouse, 2004), whereas the dam on the Little Blue River (Longview Lake) was completed in 1985
(U.S. Army Corps of Engineers, 2014). About one-half, or $292 \mathrm{~km}^{2}$, of the drainage area of the Little Blue River Basin is regulated by these reservoirs.

Some of the streams in Independence have stream classifications as designated by the State of Missouri. The Little Blue River is classified by the State of Missouri as a Class $\mathrm{P}$ (perennial) stream suitable for whole-body contact and secondary contact recreation (Missouri Department of Natural Resources, 2014a). The East Fork of the Little Blue River and Fire Prairie Creek are also Class P. Burr Oak Creek is a Class $\mathrm{C}$ stream, meaning it has perennial pools that may cease flow during periods of drought. The remaining streams in Independence are currently (2014) unclassified. Within Independence, the streams are mostly channelized. The Little Blue River also is listed in the Missouri Code of State Regulations (10 CSR 20-7) as a metropolitan no discharge stream (Missouri Department of Natural Resources, 2014a).

Land use within the Independence city limits is a mix of developed (residential, commercial, industrial) and undeveloped (primarily agricultural, grassland, or forest, fig. 2). The western part of Independence is primarily urbanized, whereas the eastern and northern parts of the city are characterized by large tracts of undeveloped land, including forests, grasslands, and croplands, with some new residential construction on what had previously been vacant and agricultural-zoned land. Adair Creek (table 1; fig. 2) had the highest percentage ( 90.5 percent) of developed land (including open/low intensity and medium/high intensity land), whereas Fire Prairie Creek had the highest percentage ( 87.9 percent) of undeveloped land (including grassland/cultivated crops, mixed forest, water, wetlands, and barren land).

The 27-year monthly averages for temperature and precipitation in the study area indicate that July is typically the warmest month of the year and June is the wettest month (fig. 3). The 27-year comparison period was chosen because it represents the period since construction was completed for the last reservoir to regulate flow in the Little Blue River Basin. The average monthly temperatures during the study period from June 2005 to September 2013 were generally near or above the 27-year monthly averages (fig. 3). The late winter and spring months (February, March, April, and May) as well as September and December for the entire study period were wetter than the 27-year monthly averages for those months. The summer months of June, July, and August, and the fall months of October and November, as well as January, were drier than the 27-year monthly average precipitation for those months.

The wettest water year (WY; 12-month period from October 1 to September 30, designated by the calendar year in which it ends) during the study period was WY 2008, followed by WY 2010 (fig. 4). The driest WY was 2006, followed by WY 2012. The 30-year average annual precipitation by calendar year (CY) for Independence, is 110.9 centimeters $(\mathrm{cm}$; 43.67 inches) (National Climatic Data Center, 2014b). 


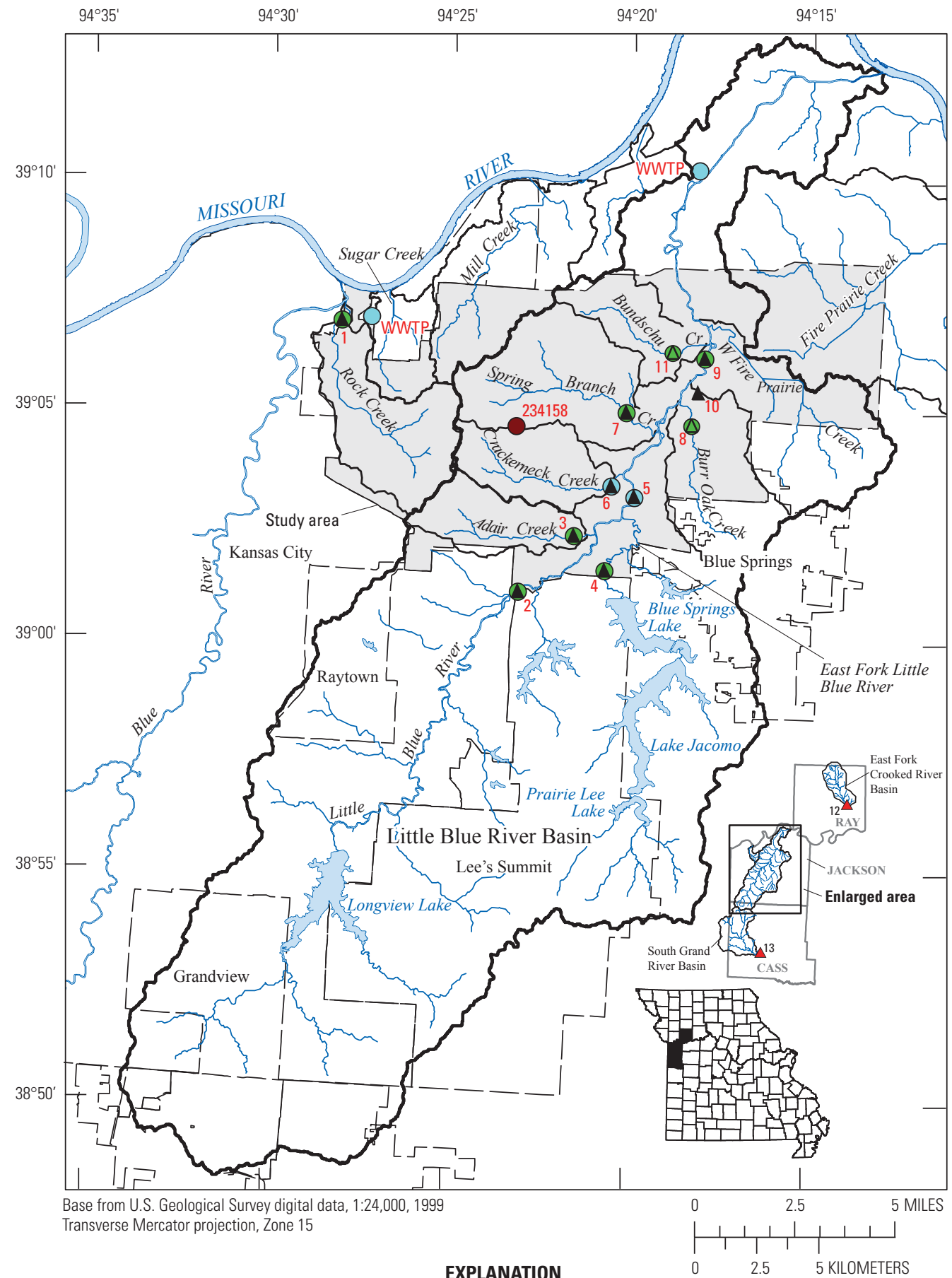

\footnotetext{
City of Independence-Study area

Water-quality and biologic sampling site with streamgage and continuous water quality-Table 2

(4) Water-quality and biologic sampling site-Table 2

$0^{6} \quad$ Water-quality and biologic sampling site with discontinued streamgage and continuous water quality-Table 2

$\Delta^{10}$ Biologic sampling site-Table 2

$\triangle^{13} \quad$ Rural comparison biologic sampling site-Table 2

234158 National Weather Service Cooperative Station 234158 - From 2001 to present (2014)

WWTP Wastewater treatment plant
}

Figure 1. The Little Blue River Basin, sampling sites, study area location, and political boundaries for Independence, Missouri, and surrounding cities. 


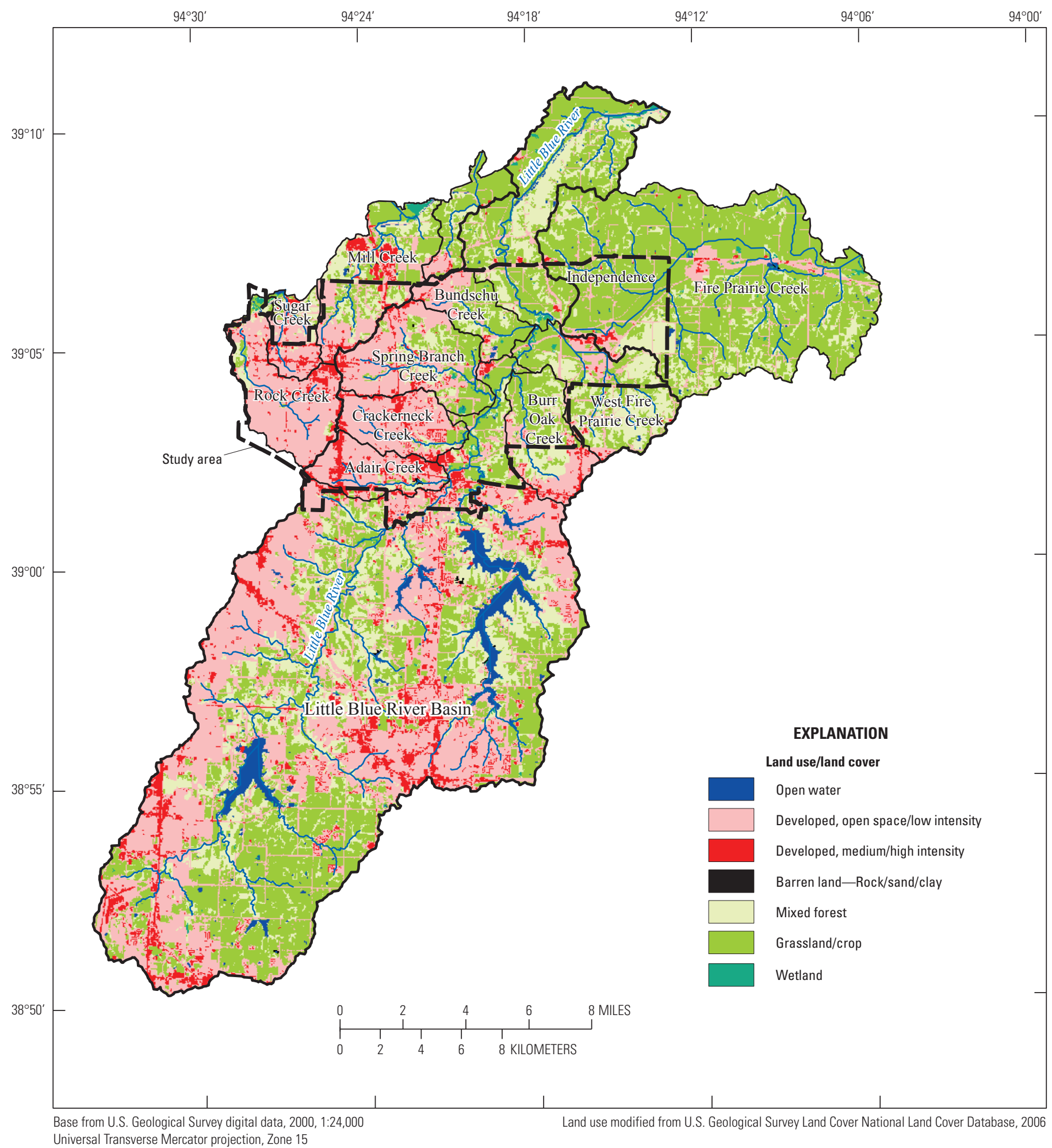

Figure 2. Land use/land cover in the Little Blue River Basin and adjacent basins within Independence, Missouri. 
Table 1. Land use in the City of Independence and basins wholly or partially within Independence city boundaries.

$\left[\mathrm{km}^{2}\right.$, square kilometer; --, no data]

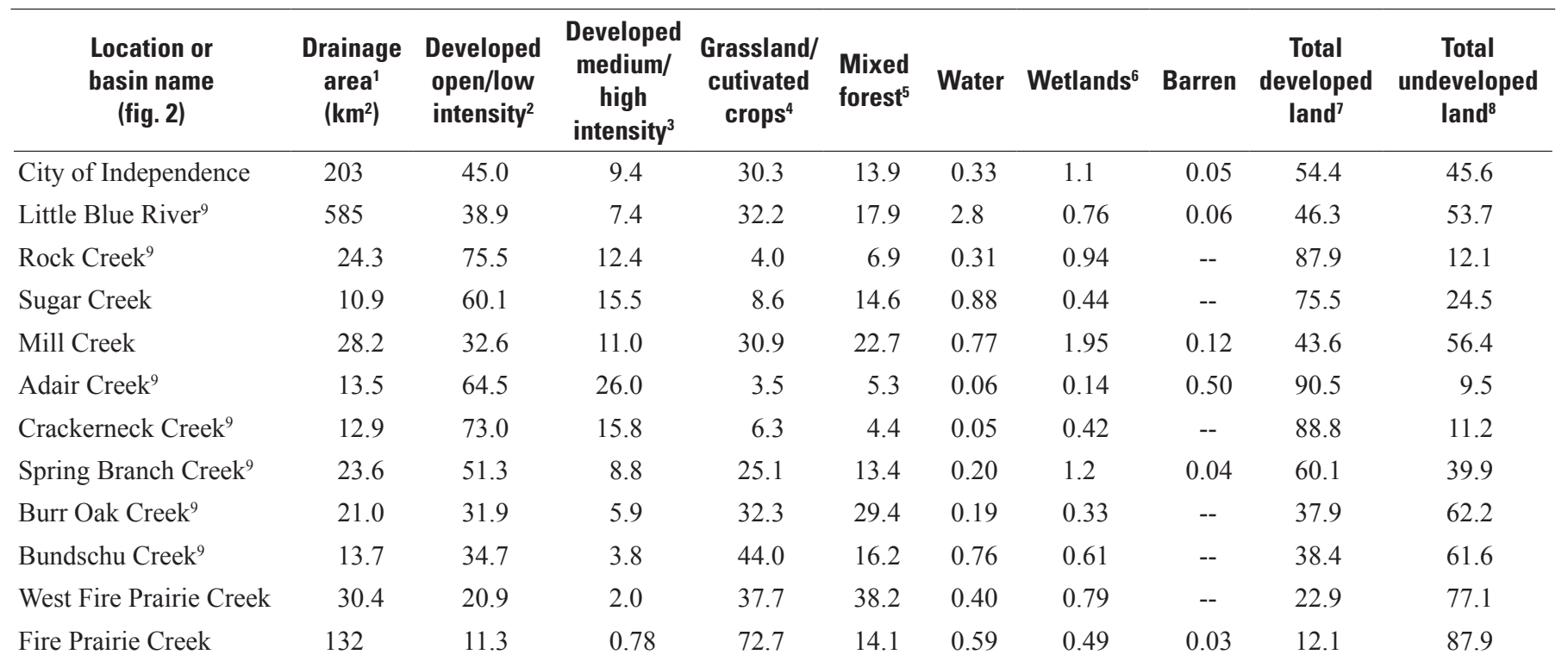

${ }^{1}$ Drainage areas for sites with sampling locations are for the area upstream from the sampling location.

${ }^{2}$ Includes the National Land Cover Database (U.S. Geological Survey, 2006) land cover categories: developed, open space; developed, low intensity.

${ }^{3}$ Includes the National Land Cover Database (U.S. Geological Survey, 2006) land cover categories: developed, medium intensity; developed, high intensity.

${ }^{4}$ Includes the National Land Cover Database (U.S. Geological Survey, 2006) land cover categories: shrub/scrub; grassland/herbaceous; sedge/herbaceous; pasture/hay; cultivated crops.

${ }^{5}$ Includes the National Land Cover Database (U.S. Geological Survey, 2006) land cover categories: deciduous forest; evergreen forest; mixed forest.

${ }^{6}$ Includes the National Land Cover Database (U.S. Geological Survey, 2006) land cover categories: woody wetlands; emergent herbaceous wetlands.

${ }^{7}$ Total of developed open/low intensity and developed medium/high intensity land.

${ }^{8}$ Total of grassland/cultivated crops, mixed forest, water, wetlands, and barren land.

${ }^{9}$ Sampling site located in basin.

\section{Previous Investigations}

In June 2005, the USGS began to collect and analyze base-flow and stormflow samples from selected streams within the city limits of Independence. The objective of waterquality monitoring was to characterize and assess contaminant sources, concentrations, loads, and yields of various constituents and their contributions to the water-quality and ecological condition of the Little Blue River from various basins and receiving streams. The first phase of the study (Christensen and others, 2010) collected data from June 2005 through December 2008 and included fewer sampling sites, less frequent base-flow sampling, and fewer analyzed constituents (pesticides, sulfate, and hardness were added in WY 2010) than the current phase of the study. The calculated loads published in Christensen and others (2010) may differ from those presented in this report because additional data from WYs 2009 to 2013 have been added to the calculations. Data used to evaluate the ecological health of Independence streams also were previously published in Christensen and Krempa (2012) and included data collected during WYs 2007 to 2011.
The hydrologic monitoring network within Independence includes eight USGS streamgaging stations with varying periods of record. All sites except the Little Blue River near Lake City, Mo., were installed during this study. Streamflow measurements on the Little Blue River near Lake City, Mo. (site 9; fig. 1; table 2 have been maintained continuously and are available from 1948 to the present (2014; U.S. Geological Survey, 2009). Other streamgages have periodically been operated within Independence, through both the Nationwide Urban Runoff Program (NURP) study (U.S. Environmental Protection Agency, 1983) and the USGS in 1992 and 1993 (Schalk, 1993).

The U.S. Environmental Protection Agency (EPA) conducted the NURP research project between 1979 and 1983 (U.S. Environmental Protection Agency, 1983). The NURP was the first comprehensive study of urban stormwater pollution in the United States. The current (2014) Rock Creek sampling site (site 1; table 2; fig. 1) was the previous location of NURP site RS3 (Mid-America Regional Council and F.X. Browne Associates, Incorporated, 1983). The NURP study 

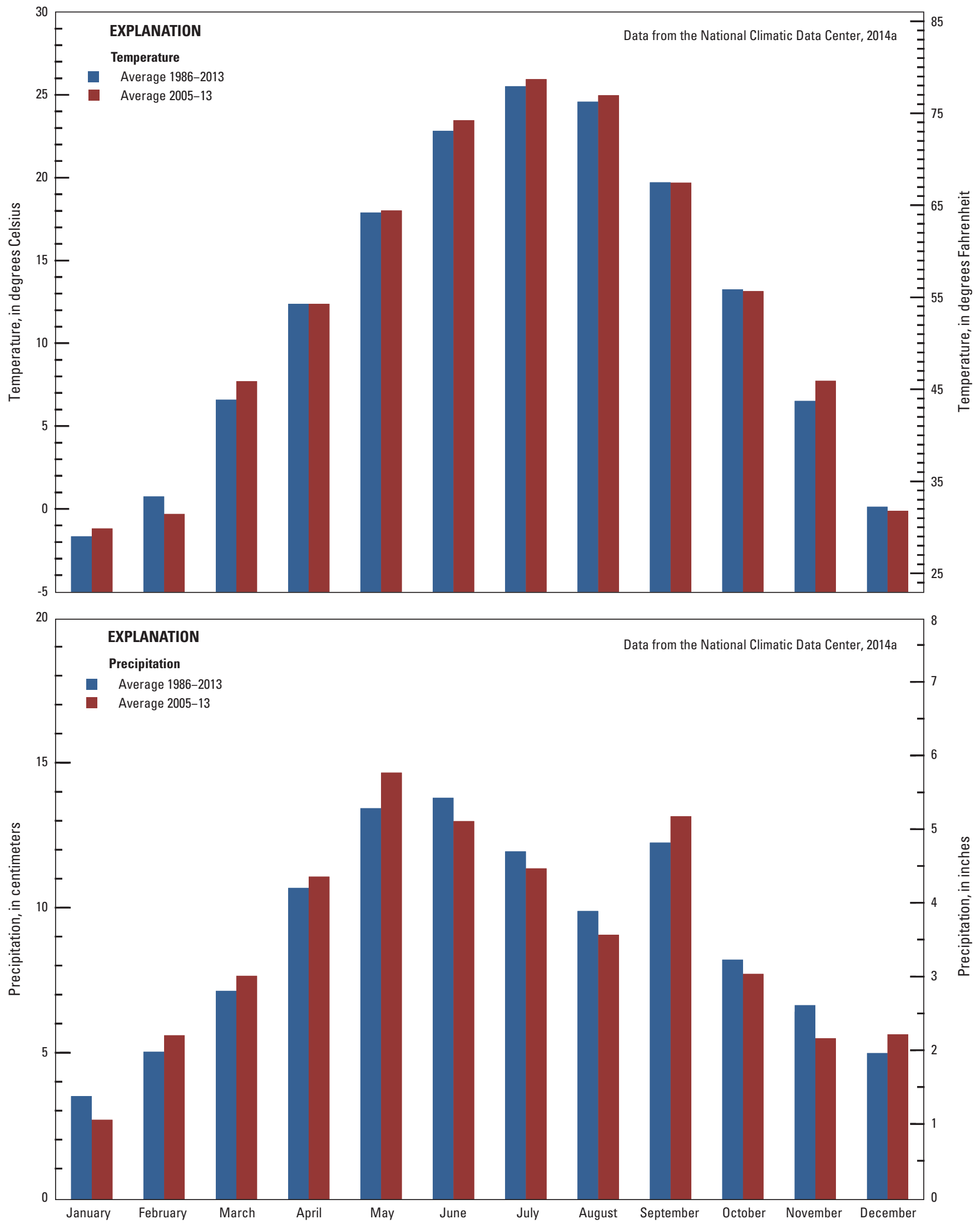

Figure 3. Average monthly temperatures and precipitation at Independence, Missouri, for June 2005 through September 2013 compared to the 27-year average from October 1986 through September 2013. 


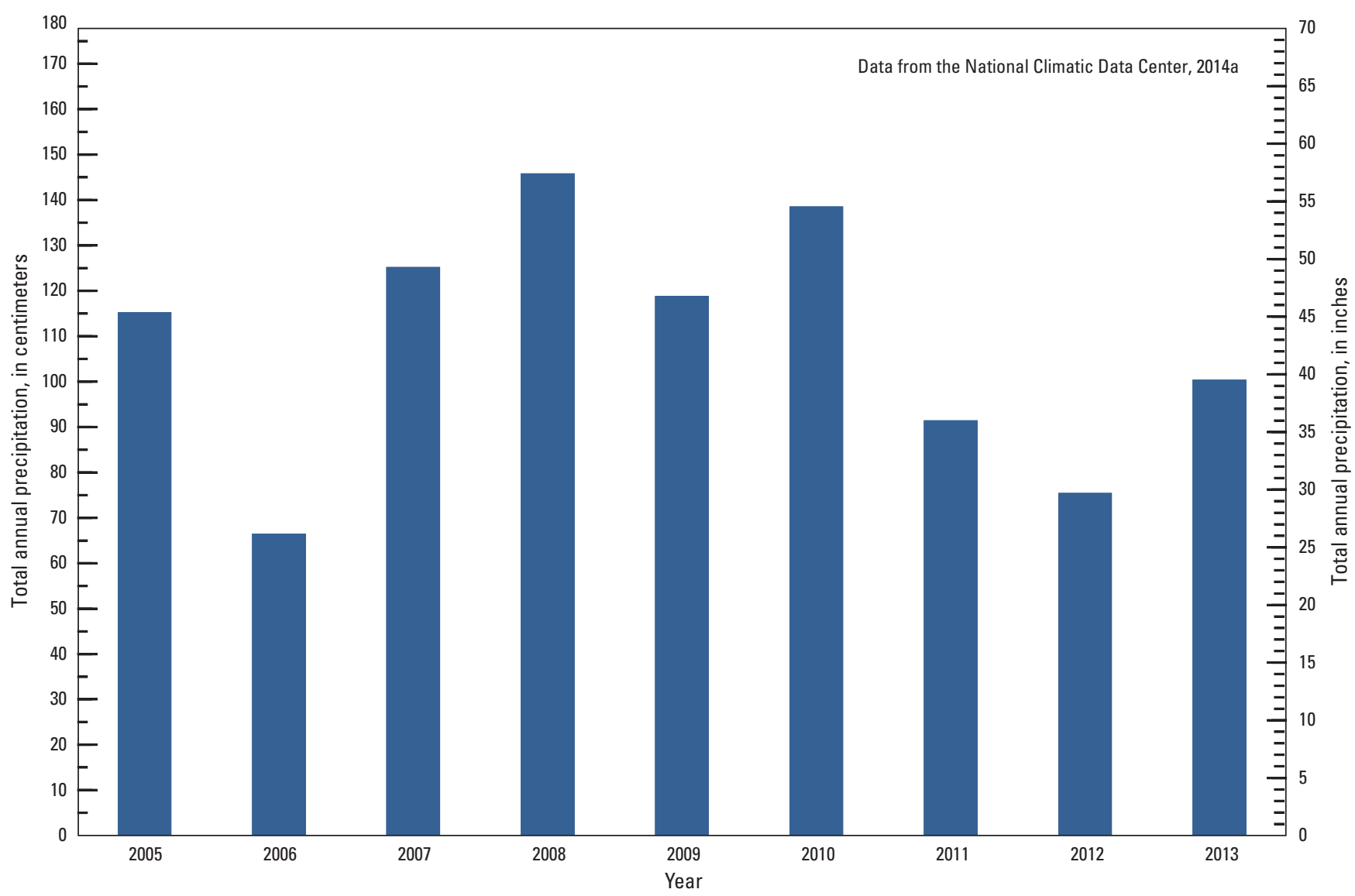

Figure 4. Annual precipitation for Independence, Missouri, water years (October 1 through September 30) 2005 through 2013.

concluded that urban runoff was the cause of much pollution and the goals of the Clean Water Act would not be met if action was not taken (U.S. Environmental Protection Agency, 1983). The NPDES permit program was founded on the results of the NURP study.

During the initial phase of the NPDES permit process, the USGS, in cooperation with Independence, did a study from 1991 to 1992 to evaluate the water quality of base flow and stormflow in Independence streams from five basins within Independence (Schalk, 1993). A total of 226 base-flow samples were collected and analyzed for four indicators of point-source discharges: chlorine, copper, phenols, and total detergents. Fifty-two samples (23 percent) had detections of chlorine, there was a single detection of total detergents, and there were no detections of copper or phenols that were higher than the existing method detection limits (MDL) from that study period; however, current (2014) MDLs used for this report are lower. Stormflow samples collected during three storms were analyzed for physical properties, nutrients, trace elements, pesticides, volatile and semivolatile organic compounds, and FIB.
Point and non-point source illicit discharges of pollutants to streams can be detected through the measurement of OMCs (Kolpin and others, 2002; Zaugg and others, 2006). Previous studies have used OMCs when evaluating streams affected by wastewater and wastewater treatment plant discharges, including studies on the adjacent Blue River Basin in Missouri and Kansas (Wilkison and others, 2002, 2006, 2009; Lee and others, 2005). OMCs can originate, however, from sources other than wastewater discharges, such as runoff from chemically treated or impervious surfaces, organic plant matter, landfills and garbage, construction materials, groundwater, and atmospheric deposition (Adolphson and others, 2001; Peck and Hornbuckle, 2006; Ternes and Joss, 2006; Senior and Cinotto, 2007; Musolff and others, 2009). Although OMCs have traditionally been referred to in the literature as wastewater contaminants or wastewater indicator compounds (Kolpin and others, 2002; Wilkison and others, 2002, 2006, 2009; Zaugg and others, 2002, 2006; Lee and others, 2004; Lee and others, 2005), in this report these compounds will be referred to by the generic term of common organic micro-constituents, or OMCs. 
Table 2. Sampling sites in Independence, Missouri, biologic sampling reference sites, and type of hydrologic, water-quality, and ecologic data collected, June 2005 through September 2013.

[USGS, U.S. Geological Survey; ID, identification number; ddmmss, degrees/minutes/seconds; km², square kilometers; mi², square miles; QC, continuous streamflow; PCP, precipitation; BQW, base-flow water quality; SQW, stormflow water quality; CWQM, continuous water-quality monitor; IQW, benthic macroinvertebrates; HAB, habitat assessment; DWS, dry-weather screening;

$\mathrm{X}$, sampled; NA, not applicable; --, not sampled]

\begin{tabular}{|c|c|c|c|c|c|c|c|c|c|c|c|c|c|c|c|}
\hline $\begin{array}{c}\text { Site } \\
\text { number } \\
\text { (fig. 1) }\end{array}$ & Station name or basin & Short station name & USGS station ID & $\begin{array}{l}\text { Latitude } \\
\text { (ddmmss) }\end{array}$ & $\begin{array}{l}\text { Longitude } \\
\text { (ddmmss) }\end{array}$ & $\begin{array}{c}\text { Drainage } \\
\text { area }^{1} \\
\left(\mathbf{k m}^{2}\right)\end{array}$ & $\begin{array}{c}\text { Drainage } \\
\text { area }^{1} \\
\left(\mathrm{mi}^{2}\right)\end{array}$ & OC & PCP & Bow & sow & CWOM & IOW & HAB & DWS \\
\hline 1 & $\begin{array}{l}\text { Rock Creek at Kentucky Road in } \\
\text { Independence, Mo. }\end{array}$ & Rock Creek & 06893620 & 390643 & 0942820 & 24.3 & 9.4 & $\mathrm{X}$ & $\mathrm{X}$ & $\mathrm{X}$ & $\mathrm{X}$ & $\mathrm{X}$ & $\mathrm{X}$ & $\mathrm{X}$ & $\mathrm{X}$ \\
\hline NA & Sugar Creek & NA & NA & NA & NA & 10.9 & 4.2 & -- & -- & -- & -- & -- & -- & -- & $\mathrm{X}$ \\
\hline NA & Mill Creek & NA & NA & NA & NA & 28.2 & 10.9 & -- & -- & -- & -- & -- & -- & -- & $\mathrm{X}$ \\
\hline 2 & $\begin{array}{l}\text { Little Blue River at Lee's Summit Road in } \\
\text { Independence, Mo. }\end{array}$ & Lee's Summit Road & 06893820 & 390102 & 0942314 & 255 & 98.4 & $\mathrm{X}$ & $\mathrm{X}$ & $\mathrm{X}$ & $\mathrm{X}$ & $\mathrm{X}$ & $\mathrm{X}$ & $\mathrm{X}$ & $\mathrm{X}$ \\
\hline 3 & Adair Creek at Independence, Mo. & Adair Creek & 06893830 & 390216 & 0942148 & 13.5 & 5.2 & $\mathrm{X}$ & $\mathrm{X}$ & $\mathrm{X}$ & $\mathrm{X}$ & $\mathrm{X}$ & $\mathrm{X}$ & $\mathrm{X}$ & $\mathrm{X}$ \\
\hline 4 & $\begin{array}{l}\text { East Fork Little Blue River near Blue } \\
\text { Springs, Mo. }\end{array}$ & East Fork & 06893890 & 390132 & 0942037 & 89.1 & 34.4 & $\mathrm{X}$ & $\mathrm{X}$ & $\mathrm{x}$ & $\mathrm{X}$ & $\mathrm{X}$ & $\mathrm{X}$ & $\mathrm{X}$ & $\mathrm{X}$ \\
\hline 5 & $\begin{array}{l}\text { Little Blue River at 39th Street in } \\
\text { Independence, Mo. }{ }^{2}\end{array}$ & 39th Street & 06893910 & 390250 & 0942015 & 409 & 158 & $\mathrm{X}$ & $\mathrm{X}$ & $\mathrm{X}$ & $\mathrm{x}$ & $\mathrm{X}$ & $\mathrm{X}$ & $\mathrm{X}$ & $\mathrm{X}$ \\
\hline 6 & $\begin{array}{l}\text { Crackerneck Creek at Selsa Road in } \\
\text { Independence, } \mathrm{Mo}^{3}\end{array}$ & Crackerneck Creek & 06893940 & 390322 & 0942041 & 12.9 & 5.0 & $\mathrm{X}$ & $\mathrm{X}$ & $\mathrm{X}$ & $\mathrm{X}$ & -- & $\mathrm{X}$ & $\mathrm{X}$ & $\mathrm{X}$ \\
\hline 7 & $\begin{array}{l}\text { Spring Branch Creek at Holke Road in } \\
\text { Independence, } \mathrm{Mo}^{4}\end{array}$ & Spring Branch & 06893970 & 390518 & 0942036 & 24.1 & 9.3 & $\mathrm{X}$ & $\mathrm{X}$ & $\mathrm{X}$ & $\mathrm{X}$ & $\mathrm{X}$ & $\mathrm{X}$ & $\mathrm{X}$ & $\mathrm{X}$ \\
\hline 8 & Burr Oak Creek at Independence, Mo. & Burr Oak & 06893990 & 390510 & 0941832 & 21.0 & 8.1 & -- & -- & $\mathrm{X}$ & $\mathrm{X}$ & -- & $\mathrm{X}$ & $\mathrm{X}$ & $\mathrm{X}$ \\
\hline 9 & Little Blue River near Lake City, Mo. & Lake City & 06894000 & 390602 & 0941801 & 505 & 195 & $\mathrm{X}$ & $\mathrm{X}$ & $\mathrm{X}$ & $\mathrm{X}$ & $\mathrm{X}$ & $\mathrm{X}$ & $\mathrm{X}$ & $\mathrm{X}$ \\
\hline 10 & Cut-off Meander near Lake City, Mo. & Cut-off Meander & 390259094201201 & 390259 & 0942012 & NA & NA & -- & -- & -- & -- & -- & $\mathrm{X}$ & $\mathrm{X}$ & -- \\
\hline 11 & $\begin{array}{l}\text { Bundschu Creek at North Little Blue } \\
\text { Parkway in Independence, Mo. }\end{array}$ & Bundschu Creek & 390617094190201 & 390617 & 0941902 & 13.7 & 5.3 & -- & -- & $\mathrm{X}$ & $\mathrm{X}$ & -- & -- & -- & $\mathrm{X}$ \\
\hline NA & West Fire Priarie Creek & NA & NA & NA & NA & 30.4 & 11.7 & -- & -- & -- & -- & -- & -- & -- & $\mathrm{X}$ \\
\hline 12 & $\begin{array}{l}\text { East Fork Crooked River near Richmond, } \\
\text { Mo. }\end{array}$ & Crooked River Richmond & 06895090 & 392222 & 0945432 & 249 & 96 & -- & -- & -- & -- & -- & $\mathrm{X}$ & $\mathrm{X}$ & -- \\
\hline 13 & South Grand River below Freeman, Mo. & South Grand Freeman & 06921582 & 383520 & 0942630 & 388 & 150 & -- & -- & -- & -- & -- & $\mathrm{X}$ & $\mathrm{X}$ & -- \\
\hline
\end{tabular}

${ }^{1}$ Drainage areas for sites with station IDs are for the area upstream from the streamgage and sampling location.

${ }^{2}$ Streamgage discontinued October 2009.

${ }^{3}$ Streamgage discontinued October 2008

${ }^{4}$ Spring Branch streamgage moved downstream to Missouri State Highway 78 bridge on August 15, 2007, due to sedimentation at the original location on Holke Road. The drainage area at the upstream site was $23.6 \mathrm{~km}^{2} / 9.1 \mathrm{mi}^{2}$. 


\section{Methods}

Samples were collected from June 2005 through September 2013 at 13 sites; eight streamgages, two ungaged sites, a cut-off meander, and two biological reference sites. The locations of sampled sites and type of hydrologic, water quality, and ecologic data collected are listed in table 2 and figure 1. Sites will be referred to by site number (1 through 13) for the remainder of the report. The numerical reference will follow the same downstream order as the USGS station identifiers (table 2; fig. 1). Sites will be referred to as the following: site 1, Rock Creek at Kentucky Road in Independence, Mo. (hereafter referred to as "Rock Creek"); site 2, Little Blue River at Lee's Summit Road in Independence, Mo. (hereafter referred to as "Little Blue River at Lee's Summit Road"); site 3, Adair Creek at Independence, Mo. (hereafter referred to as "Adair Creek"); site 4, East Fork Little Blue River near Blue Springs. Mo. (hereafter referred to as "East Fork Little Blue River"); site 5, Little Blue River at 39th Street in Independence, Mo. (hereafter referred to as "Little Blue River at $39^{\text {th }}$ Street"); site 6, Crackerneck Creek at Selsa Road in Independence, Mo. (hereafter referred to as "Crackerneck Creek"); site 7, Spring Branch Creek at Holke Road in Independence, Mo. ( hereafter referred to as "Spring Branch Creek"); site 8, Burr Oak Creek at Independence, Mo. (hereafter referred to as "Burr Oak Creek"); site 9, Little Blue River near Lake City, Mo. (hereafter referred to as "Little Blue River near Lake City"); site 10, Cut-off meander near Lake City, Mo. (hereafter referred to as "Cut-off meander near Lake City" ); site 11, Bundschu Creek at North Little Blue Parkway in Independence, Mo. (hereafter referred to as "Bundschu Creek"); site 12, East Fork Crooked River near Richmond, Mo. (hereafter referred to as "East Fork Crooked River"); and site 13, South Grand River below Freeman, Mo. (hereafter referred to as "South Grand River").

Continuous streamflow and water-quality, and discrete base-flow and stormflow data were collected from sites 1 through 5, 7, and 9 (site 5 discontinued in WY 2009). All data except continuous water-quality were collected at site 6 until the discontinuation of that site in WY 2008. Two ungaged sites (sites 8 and 11) were sampled for base-flow and stormflow water quality. Sites 12 and 13 were selected as comparison control sites for habitat assessment and benthic macroinvertebrate samples because they are relatively undeveloped compared to the Independence sites and are within the same ecoregions as Independence; these sites were located outside of the study area (fig. 1). One additional ungaged site within Independence (site 10) also was selected for benthic macroinvertebrate sampling and habitat assessment because it was in an undeveloped area closer to the other sampling sites and within the city limits. Additional sampling sites were selected during dry-weather screening based on conditions at the sites at the time of sampling.

Stream sampling sites were selected because they are representative of Independence's contribution to the water quality of the Little Blue River, and streams that drain developed areas of Independence that receive discharge from the MS4. The types of data collected at each sampling site included streamflow, physical and chemical properties, TDS, sodium, chloride, nutrients, metals, OMCs, pesticides in streambed sediment and surface water, FIB, and SSC. Low-flow (dry-weather) screening was also conducted at sampling sites and along the length of the streams draining Independence to monitor for point-source discharges and stream degradation such as garbage dumping. Water-quality samples also were collected and analyzed on a regular basis at three ungaged sites, Crackerneck Creek (site 6; subsequent to the removal of the gage in October 2008), Burr Oak Creek (site 8), and Bundschu Creek (site 11; table 2; fig. 1). Benthic macroinvertebrate community surveys and habitat assessments also were done.

\section{Streamflow and Continuous Water-Quality Monitoring}

Streamflow measurements were made on all sites at regular intervals using standard USGS methods (Rantz and others, 1982; U.S. Geological Survey, 2004; Oberg and others, 2005; Turnipseed and Sauer, 2010; Mueller and others, 2013), and were used to determine and maintain stage-discharge relations for each site. Streamflow at each individual site during base flow and stormflow was determined using the stage-discharge relationship (Rantz and others, 1982), or was measured or estimated at the time of sampling. Water surface elevation (stage) data were measured and recorded at eight sites using noncontact radar stage sensors and pressure transducers. Sites 2 , 5, and 9-all located on the Little Blue River-were equipped with non-contact radar stage sensors, and sites $1,3,4,6$, and 7 used pressure transducers. Sites 1, 3, 6, and 7 are "flashy" in nature with rapid increases and decreases of flow, so that these sites measured, but did not record, stage data in 5-minute intervals. Stage data were recorded in 15-minute increments and transmitted by way of satellite telemetry to the National Water Information System (NWIS) for streamflow computation and records archival. Data are available for public display through NWISWeb (http://waterdata.usgs.gov) and updated hourly.

Streamgages were equipped with unheated tipping-bucket rain gages to collect a cumulative total of precipitation every 15 minutes. The rain gages were checked, cleaned, and maintained as necessary and were calibrated annually to ensure an accuracy of $0.025 \mathrm{~cm}$ of precipitation. National Weather Service (NWS) cooperative station data (station 234158 fig. 1) were used to supplement tipping-bucket rain gage data during times of snowfall or other freezing precipitation because unheated tipping buckets are not able to accurately measure precipitation during freezing conditions. Climatic data, including precipitation, have been measured at a NWS cooperative station in Independence since 1973 (National Climatic Data Center, 2014a). 


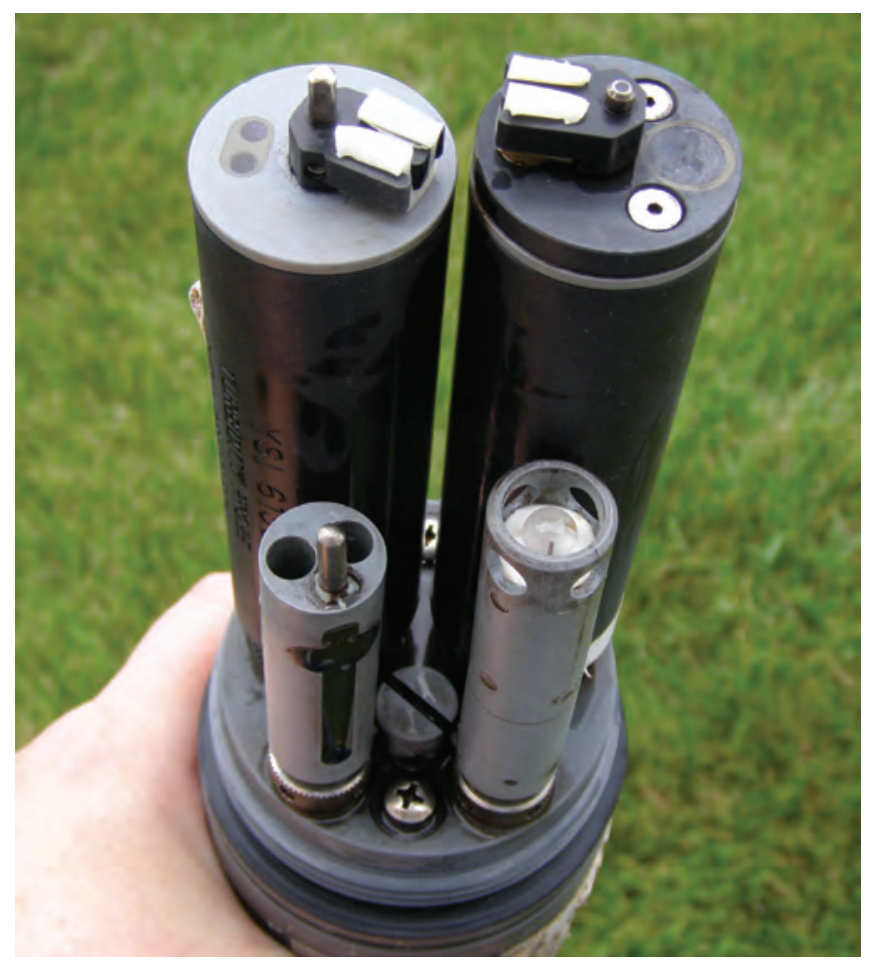

Figure 5. Continuous water-quality monitor with (clockwise from upper left) turbidity, optical dissolved oxygen, $\mathrm{pH}$, and combined specific conductance and water temperature sensors.

Six sites (sites 1 through 4, 7, and 9) are currently (2014) equipped with CWQMs (table 2; fig. 1) and operated and maintained according to standard USGS procedures (Wagner and others, 2006). An additional little Blue River site, site 5, was equipped with a CWQM, but was discontinued in October 2009. The CWQMs record water-quality values every 15 minutes. All sites with CWQMs are currently (2014) equipped with sensors to record specific conductance, water temperature, turbidity, and, at different periods during the study, dissolved oxygen and pH (fig. 5). The two Little Blue River sites (sites 2 and 9) are currently (2014) equipped with dissolved oxygen sensors, and site 9 also is equipped with a $\mathrm{pH}$ sensor. All real-time and daily data recorded from July 2005 through September 2013 are stored and made available from the USGS NWIS at http://waterdata.usgs.gov/mo/nwis/ $q w$.

Continuous water-quality monitors were installed at a total of seven sites. Three sites (sites 5, 7, and 9; table 2; fig. 1) were the first to be equipped with CWQMs installed inside 46-cm diameter corrugated metal pipe cut to 1-meter (m) lengths and secured to the bottom of the stream. The pipes were positioned within the main channel such that water velocity could be maintained during periods of low flow, and repositioned as necessary to ensure adequate flow around the sensors. Frequent shallow water depths and severe sediment deposition at site 7 later forced the relocation of the streamgage and CWQM to a site downstream. The CWQM at the new site was installed in a 10.2-cm diameter polyvinyl chloride (PVC) conduit attached to the bank and positioned near the center of flow. This installation was slightly repositioned closer to the bank and then later replaced with a $46-\mathrm{cm}$ diameter metal corrugated conduit to prevent damage from storm events. The CWQMs installed at site 1 and site 2 also were installed in metal conduits attached to the streambed, and the CWQMs installed at site 3 and site 4 were installed in 10.2-cm PVC pipes attached to the concrete culvert walls at the sites. Cross-section measurements were made with a CWQM designated as a field meter to ensure that the placement of the CWQM adequately represented parameter readings across the stream (Wagner and others, 2006). The CWQMs at all sites are subject to biofouling, sedimentation, and calibration drift, and were cleaned and calibrated on a regular basis. Sites were visited monthly on average, but site visits ranged from 1 to 214 days between visits, depending on sensor performance, season, and site conditions. Flooding on occasion greatly increased the amount of time between some site visits. The measured CWQM data were corrected based on manufacturer's specifications, site knowledge, and USGS methods and procedures as described in Wagner and others (2006).

\section{Water-Quality Sample Collection and Procedures}

Base-flow (defined as streamflow unaffected by runoff) and stormflow samples were collected at 10 sites in Independence (sites 1 through 9 and 11) at varying intervals during the study period from June 2005 through September 2013. The method of collection varied based on sample conditions and analyzed constituents varied only slightly between base-flow and stormflow samples.

Base-flow samples were collected annually from June 2006 to May 2008, twice annually from the fourth quarter of WY 2008 through WY 2009, three times in WY 2010, and quarterly beginning in WY 2011, with additional snowmelt samples collected to characterize winter conditions. Grab samples were collected in the centroid of flow during base-flow conditions and analyzed for selected water-quality constituents.

Stormflow water-quality samples were collected quarterly beginning in June 2005 at sites 1-9 and 11 (table 2; fig. 1), with additional samples collected to characterize water quality during winter conditions or to make up for any constituent analyses that may have been omitted during previous stormflow sampling periods as a result of insufficient sample volume. Stormflow samples were collected using automatic samplers, or as grab samples at the centroid of flow if there was not a streamgage installed at the site or if the automatic samplers malfunctioned. Two complete sets of stormflow samples were taken as grabs, one prior to the installation of the automatic samplers in June 2005 and one in October 2007 when the automatic samplers failed to function. 
Automatic samplers were programmed to collect a flowweighted sample at sites with a streamgage once a designated stage threshold was exceeded. The individual samples were pumped at a pre-programmed interval and combined into one composite sample in a 9.5-liter glass receiving vessel. Sampling intervals were programmed based on the interval of continuous streamflow data collection. Sites were typically sampled every 15 minutes except for the smaller streams (sites 1, 3, 6, and 7), which were sampled every 5 minutes. The samplers were programmed specifically for each storm for the expected streamflow at each site and to obtain the most representative sample over the rise, peak, and recession of streamflow; however, given the unpredictability of precipitation and runoff during storms, volume of stormflow, and the length of recession at each site for each storm, the rise of streamflow was sampled more frequently than the peak or recession. For storm events of prolonged duration, the samples were either preserved by placing them on ice in the sampler, or by removing and refrigerating the partial sample and compositing it at a later time with the additional sample from the remainder of the storm event. Detailed USGS storm sampling procedures can be obtained in the USGS "National Field Manual for the Collection of Water Quality Data" (U.S. Geological Survey, variously dated).

For composite samples collected by automatic sampler, streamflow was calculated as an average of the calculated 15 -minute streamflow values, computed from the established stage-discharge relationship for each site, over the interval of sample collection. Streamflow for grab samples was either determined from an established stage-discharge relationship at each streamgage or measured at the time of sampling at the site. Streamflow values were used in the calculation of annual loads of selected constituents.

Physical and chemical properties and selected water-quality constituents were analyzed from samples collected during base flow and stormflow. Physical and chemical properties (dissolved oxygen, $\mathrm{pH}$, specific conductance, water temperature, and turbidity) were measured at all sites (sites 1 through 9 and 11; table 2; fig. 1) in the stream during base-flow and stormflow sampling with calibrated CWQMs or field meters during sampling, or in the collected sample in the laboratory. Base-flow and stormflow samples were analyzed for TDS, sodium, chloride, nutrients (nitrogen $[\mathrm{N}]$ and phosphorous $[\mathrm{P}]$ species), total metals (aluminum, cadmium, chromium, copper, lead, zinc, and arsenic), dissolved mercury, cyanide, OMCs, FIB, and SSC. Dissolved metals analysis was done on one set of stormflow samples to assess the bioavailability of metals during stormflow. Analyses for 5-day biologic oxygen demand $\left(\mathrm{BOD}_{5}\right)$, chemical oxygen demand (COD), and oil and grease in base-flow and stormflow samples were done by, and data are available on file with, the City of Independence WPC Environmental Compliance Testing Laboratory (L. White, oral commun., 2014). Chlorophyll samples were also collected during base-flow sampling, but the data were not used for the purposes of this report. Sulfate and hardness during base flow and stormflow were added beginning in September 2012 and
November 2012. Results for these two constituents are not presented because of the small number of samples collected through September 2013. Fourteen base-flow samples were analyzed for pesticides in streambed sediment from July 2010 to July 2013 and 17 stormflow and 2 base-flow samples were analyzed for pesticides in water from September 2010 to June 2013.

After collection, base-flow and stormflow samples were taken to the USGS Water Science Center in Lee's Summit, Mo., to prepare aliquots for chemical analyses. All constituents except cyanide, pesticides in streambed sediment, and chlorophyll were collected as either grab samples during base flow or from automatic samplers during stormflow, in clean and sterilized 9.5-liter glass bottles. Collection bottles received multiple sequential rinses with detergent, dilute hydrochloric acid, methanol, and de-ionized and organic free water before use. Upon arrival at the laboratory, samples were transferred to a churn splitter that was cleaned and sterilized using the same procedures as for the glass collection bottles. Aliquots were removed from the churn splitter and placed in individual bottles for each respective constituent or group of constituents (total nutrients, total metals, OMCs, and pesticides) to be analyzed as raw samples. Any samples that required filtration were filtered according to established USGS procedures (U.S. Geological Survey, variously dated) using 0.45 micron $(\mu \mathrm{m})$ cartridge filters. Samples to be analyzed at the USGS National Water Quality Laboratory (NWQL), in Lakewood, Co. (including TDS, sodium, chloride, nutrients, metals, OMCs, pesticides in streambed sediment and surface water, and sulfate) were placed on ice and shipped within 24 hours of processing.

Cyanide, pesticides in streambed sediment, and chlorophyll were collected in separate containers for direct shipment to the analytical laboratories. Samples collected for cyanide were refrigerated and shipped overnight the same day to the TestAmerica (Severn-Trent) Laboratory in Arvada, Colorado, for analysis. If cyanide samples could not be shipped the same day as collection, samples were preserved with concentrated 5-normal sodium hydroxide and shipped within 1 week. Samples for pesticides in streambed sediment were collected using a stainless steel spoon and placed on ice and shipped to the NWQL. Chlorophyll samples collected in the stream were taken to the USGS laboratory in Lee's Summit, filtered using $0.7 \mu \mathrm{m}$ glass-fiber filters, and frozen until shipment on dry ice to the NWQL.

Three types of microbiological samples were collected, including FIB, MST, and influent samples, and were prepared for analysis and shipment at the USGS Lee's Summit laboratory. Samples for FIB were collected from the churn splitter in sterilized 500 milliliter $(\mathrm{mL})$ bacteria bottles. Samples for MST markers were collected from the churn splitter in $500 \mathrm{~mL}$ sterile deoxyribonucleic acid (DNA)-free bottles. The samples were refrigerated for no more than 8 hours on the day of collection before overnight shipment on ice to the University of Missouri Veterinary Pathology Laboratory, Columbia, Mo. (May through October 2007), or the USGS Ohio Water 
Microbiology Laboratory (OWML), Columbus, Ohio (June 2008 through September 2013). Samples of influent were collected from the Rock Creek wastewater treatment plant (WWTP) (fig. 1) as grab samples in sterile 500-mL DNA-free bottles. Samples were refrigerated before overnight shipment on ice to the OWML.

Forty-eight fecal source samples were collected from human and several domestic and wild animal sources (cat, chicken, cow, deer, dog, goose, horse, mouse, rabbit, and wild turkey) between September 2011 and May 2013 for comparison with environmental samples. Fecal source samples were collected in Jackson and Cass Counties, Missouri (fig. 1) except for four individual human samples that were collected in Columbus, Ohio. Twelve mixed-human sewage influent samples also were collected from influent to the City of Independence Rock Creek WWTP between September 2011 and May 2013. All fecal samples were collected with sterile equipment and placed in sterile $50 \mathrm{~mL}$ centrifuge tubes, individually sealed in ziplock bags, and immediately placed on ice for transport. Animal fecal samples (cat, chicken, cow, deer, dog, goose, horse, mouse, rabbit, and wild turkey) were collected at several locations in Jackson and Cass counties, Mo. Human fecal samples were collected in Jackson County, Mo., and Columbus, Ohio. Samples were from individual hosts, with the possible exception of the mouse samples. More than one mouse was observed at the two collection locations and multiple fecal pellets were collected for each mouse sample. Samples were refrigerated and shipped overnight on ice to the OWML. The SSC samples were collected in $350 \mathrm{~mL}$ glass sediment bottles from the churn splitter and shipped to the USGS Missouri Sediment Laboratory in Rolla, Mo.

Beginning in WY 2006, dry-weather screening was done during base-flow conditions on selected Independence streams (table 2). Personnel from the USGS and Independence WPC walked the streams from the mouth to either the source of the stream where flow was no longer evident or until the city limits were reached. All measurable inflows were identified visually (pipe, culvert, groundwater seep, tributary, pond outflow) and sampled with the exceptions of very low flow that could not be measured accurately or diffuse groundwater seeps. At each site, horizontal coordinates were obtained using a hand-held global positioning system (GPS), streamflow was estimated or measured, and physical properties ( $\mathrm{pH}$, specific conductance, and water temperature) were recorded using portable water-quality meters calibrated according to established USGS protocols (U.S. Geological Survey, variously dated). A total of 1,052 samples were collected and analyzed between June 2005 and September 2013, not including field replicates, laboratory duplicates, or blank samples. Water samples were analyzed for one or more of four constituents: total chlorine, free and complexed copper (total dissolved copper; discontinued in WY 2011), phenols, and anion surfactants, compounds commonly used in household and industrial cleaners and solvents including alkyl benzene sulfonate (ABS) and linear alkylate sulfonate (LAS). On occasion some constituents were not analyzed because of low sample volume.
Dry-weather screening analytes that had a measured value exceeding a guideline or standard for that analyte were considered to be potential sources of contamination to the stream and were considered for further investigation. The State reportable/compliance level for total chlorine of 0.13 milligrams per liter $(\mathrm{mg} / \mathrm{L})$ was used as a guideline for total chlorine (Missouri Department of Natural Resources, 2006). Unfiltered samples were used for determining total dissolved copper, which includes both free and complexed copper. A standard for total dissolved copper was not determined because Federal and State standards include only dissolved copper from filtered samples rather than unfiltered. The phenols method used for dry-weather screening measures all ortho- and meta-substituted phenols (Hach, 2002). The only standard or guideline for phenol compounds for the State of Missouri is the chronic standard for protection of aquatic life (AQL) of $0.100 \mathrm{mg} / \mathrm{L}$ (Missouri Department of Natural Resources, 2014b); therefore, the concentrations of phenols were considered to be equivalent to the concentration of the individual compound phenol for comparison. The most commonly detected surfactant (detergent) in base-flow samples was nonylphenol, a nonionic surfactant (4-nonylphenol; appendix 1, http://pubs.usgs.gov/ds/0915/downloads/ ds915_Appendix01.xlsx). The EPA freshwater standard for acute exposure for aquatic communities to nonylphenol of $0.028 \mathrm{mg} / \mathrm{L}$ (U.S. Environmental Protection Agency, 2014) was used as an arbitrary guideline for determining potentially reportable detections of anionic surfactants. This guideline is conservative because the measured concentration of a single surfactant can be expected to be less than that of all surfactants combined.

Macroinvertebrate samples were collected at sites 1 through 13 (table 2; fig. 1). The macroinvertebrate sampling protocol was based on procedures described by Barbour and others (1999) and Sarver (2003a) for the collection of qualitative samples. The richest-targeted habitat (RTH) method (Barbour and others, 1999) was used where riffle/run habitats were targeted. Samples collected from this habitat type are likely representative of the stream reach (Barbour and others, 1999; Cuffney and others, 2010). For each sample, six collections were made from various riffle locations to incorporate a variety of substrate size, stream velocity, and water depth, and samples were processed and composited in the field according to Sarver (2003a). Coarse substrate habitat was limited or unavailable at sites 4 and 12 , so some subsamples were collected from fine-grained substrate or accumulated wood/leaf debris on the stream bottom. Site 12 was discontinued after the fall 2009 sampling because of a lack of an adequate single RTH to sample. After collection, the composite sample was brought to the laboratory in Lee's Summit for further processing and placed in a lighted white processing tray with enough water to cover the bottom of the tray. A total of 600 individuals (or amount enumerated in 1 hour) were collected from the composite sample. Counting focused on maximizing sample biodiversity based on visually identified morphological differences of individuals selected during collection (Barbour and 
Table 3. Criteria for aquatic-life support categories for riffle habitats for the Missouri tributaries between the Blue and Lamine Rivers ecological drainage unit.

$[>$, greater than; <, less than $]$

\begin{tabular}{|c|c|c|c|c|c|c|c|c|c|}
\hline \multirow[t]{2}{*}{$\begin{array}{l}\text { Riffle aquatic-life support } \\
\text { category }\end{array}$} & \multicolumn{2}{|c|}{$\begin{array}{l}\text { Total taxa } \\
\text { richness }\end{array}$} & \multicolumn{2}{|c|}{$\begin{array}{c}\text { Ephemeroptera- } \\
\text { Plecoptera- } \\
\text { Trichoptera richness }\end{array}$} & \multicolumn{2}{|c|}{$\begin{array}{l}\text { Macroinvertebrate } \\
\text { biotic index }\end{array}$} & \multicolumn{2}{|c|}{$\begin{array}{l}\text { Shannon diversity } \\
\text { index }\end{array}$} & \multirow{2}{*}{$\begin{array}{l}\text { Stream } \\
\text { condition } \\
\text { index }\end{array}$} \\
\hline & Spring & Fall & Spring & Fall & Spring & Fall & Spring & Fall & \\
\hline Fully biologically supporting & $>36$ & $>37$ & $>9$ & $>9$ & $<5.5$ & $<6.5$ & $>2.27$ & $>2.39$ & $16-20$ \\
\hline Partially biologically supporting & $18-36$ & 19-37 & $5-9$ & $5-9$ & $5.5-7.7$ & $6.5-8.3$ & $1.13-2.27$ & $1.19-2.39$ & $10-14$ \\
\hline Nonbiologically supporting & $<18$ & $<19$ & $<5$ & $<5$ & $>7.7$ & $>8.3$ & $<1.13$ & $<1.19$ & $4-8$ \\
\hline
\end{tabular}

others, 2009). Finished samples were preserved with 90-percent ethanol until shipment to the NWQL for analysis.

Stream habitat assessments were completed in the fall of 2008, 2010, and 2012 and in the spring of 2010 at each sampling site to relate physical characteristics to biological variables. Ten physical-habitat characteristics (epifaunal substrate, embeddedness, velocity-depth regime, sediment deposition, channel flow status, channel alteration, riffle quality, bank stability, vegetative protection, and riparian vegetation) were measured and assigned a standardized score on a scale of 0 to 20 according to procedures described in Sarver (2003b). The scores were then summed to provide an overall assessment of stream physical-habitat quality with a total possible score of 200 indicating ideal habitat.

The Invertebrate Data Analysis System (IDAS) version 5.0 was used for processing macroinvertebrate sample data and calculating taxa richness, abundance, and diversity metrics (Cuffney and Brightbill, 2011). Because of their proximity, urban character, and potential macroinvertebrate populations, data from sites 1 through 10 were combined for the purpose of resolving taxonomic ambiguities. Rural comparison streams (sites 12 and 13) were processed together, but separately from the urban sites. About 16 percent of sample taxonomic levels and about 5 percent of abundances were assigned tolerance values because of ambiguous taxonomy. Pollution tolerance values for taxa that were used to calculate the Macroinvertebrate Biotic Index (MBI) were assigned from the Missouri taxa listings (Sarver, 2005) or, if unavailable, assigned from established regional tolerance values (Cuffney and Brightbill, 2011). Taxa were defined as intolerant if the tolerance value was less than or equal to 4 , moderately tolerant if values were greater than 4 and less than 7, and tolerant if values were greater than or equal to 7 . All metrics were calculated separately for urban and rural sites and for spring and fall seasons.

Four metrics are used by the Missouri Department of Natural Resources (MDNR) (Sarver, 2003a) in the calculation of the Missouri stream condition index (MSCI): total taxa richness (RICH), Ephemeroptera plus Plecoptera plus Trichoptera (EPT) richness (EPTR), Shannon Diversity Index (SHANDIV), and the MBI. These metrics were used to calculate the aquatic-life support (ALS) status for samples collected only from a stream's RTH, which was usually coarse-substrate riffle habitat. The MSCI is calculated from samples collected from multiple habitats within a stream reach. This study's stream condition index is noted simply as SCI because of this difference in calculation of the MSCI and the SCI. Other lesser differences in the calculation of individual metrics are noted below. Differences are not substantial and the MSCI and SCI are considered equivalent. Differences in the calculated $\mathrm{SCI}$ and component metrics for individual samples from previously published values (Christensen and Krempa, 2012) result from differences in resolving taxonomic ambiguities with the addition of more samples.

The RICH is the total number of distinct taxa present in a sample. The EPTR is the total richness of Ephemeroptera, Plecoptera, and Trichoptera taxa in a sample. The SHANDIV is a measure of taxa diversity in a community that takes into consideration taxa richness and evenness of the relative abundance of community (Shannon and Weaver, 1949). The MBI is a measure of the overall pollution tolerance of a macroinvertebrate community expressed on a scale of 0 to 10 with less tolerant individuals having a lower tolerance value and more tolerant individuals having a higher tolerance value (Sarver, 2003a) and is comparable to the Hilsenhoff Biotic Index (Hilsenhoff, 1977, 1988). The MDNR uses only the Missouri taxa listings (Sarver, 2005) when calculating the MSCI.

Breakpoints for categories used to score the ALS status of streams (table 3 ) are determined and updated frequently by MDNR. Breakpoints for the ALS of individual habitats, including riffle habitat, were obtained from the MDNR for reference streams in the Central Irregular Plains ecoregion (not shown; Omernik, 1987) and Missouri tributaries between the Blue and Lamine Rivers ecological drainage unit (not shown; Sarver and others, 2002) that includes the study area. Reference site samples were collected between April 1998 and September 2008 (David Michaelson, Missouri Department of Natural Resources, written commun., 2011).

\section{Laboratory and Data Analysis}

Samples analyzed by the USGS NWQL, including TDS, sodium, chloride, nutrients ( $\mathrm{N}$ and $\mathrm{P}$ species), total metals, dissolved mercury, cyanide, OMCs, pesticides in streambed 
sediment and surface water, SSC, and sulfate were analyzed using established USGS procedures (Fishman and Friedman, 1989; Fishman, 1993; Garbarino and Damrau, 2001; Garbarino and others, 2006; Garbarino and Struzeski, 1998; Hoffman and others, 1996; Noriega and others, 2004; Patton and Kryskalla, 2011; Patton and Truitt, 1992, 2000; Zaugg and others, 2006). Grab samples collected for cyanide were analyzed by the TestAmerica (Severn-Trent) Laboratory in Arvada, Colo., using EPA approved methods (U.S. Environmental Protection Agency, 2013). Samples for SSC concentration were analyzed by the USGS sediment laboratory in Rolla, Mo., according to procedures described in Guy (1969). Samples for chlorophyll, after being filtered in the USGS Lee's Summit laboratory, were analyzed at the NWQL according to EPA Method 445.0 (Arar and Collins, 1997). Simple summary statistics were computed based on the constituent results received from the laboratories. Any results that were less than the MRL for a constituent were not included in the summary statistical analysis.

Colorimetric analysis was used to analyze the dryweather screening samples for total chlorine, total dissolved copper, phenols, and anionic surfactants using Hach reagents and a DR $/ 2400^{\circledR}$ portable spectrophotometer at the USGS laboratory in Lee's Summit, Mo. The Hach method for total chlorine oxidizes iodide in the reagent with chlorine in the sample that forms a pink color proportionate to the total chlorine concentration (Hach Company, 2004). The analysis method for total chlorine is equivalent to accepted EPA method 330.5 for analysis of total chlorine in water or wastewater (Hach Company, 2004). The Hach method for analysis of total dissolved copper utilizes AccuVac ${ }^{\circledR}$ vials which contains a reagent that reacts with copper in the sample to form a purple-colored complex proportionate to the copper concentration (Hach Company, 2004). There is not an equivalent EPA method for analysis of total dissolved copper. The analysis method initially used for phenols was a Hach colorimetric analysis (Hach Company, 2004), but was later changed (beginning in WY 2013) to a colorimetric analysis method using a CHEMetrics VACUette kit for analysis of phenols in water (CHEMetrics, Incorporated, 2013). The Hach method for phenols analysis creates a reaction to form a dye, which is then extracted into chloroform and the color measured (Hach Company, 2004). Both the Hach and CHEMetrics methods are equivalent to accepted EPA method 420.1 for phenols in water and wastes (Hach Company, 2004; CHEMetrics, Incorporated, 2013; U.S. Environmental Protection Agency, 1978). Although the Hach method has a detection limit of $0.002 \mathrm{mg} / \mathrm{L}$ and the CHEMetrics method has a detection limit of 0.10 parts per million (ppm), or $0.10 \mathrm{mg} / \mathrm{L}$, since the analyses were being used as a screening procedure only and not a quantitative method, the higher detection limit was acceptable. The anionic surfactant method extracts the surfactants from the sample contained in a glass separatory funnel and combines them with a violet dye in solution with benzene. The benzene is then separated and analyzed for imparted color (Hach Company, 2004). There is not an equivalent EPA method for anionic surfactants.
A limitation of all colorimetric methods is that suspended material and sediment (turbidity) and certain interfering compounds may cause positive or negative bias in the sample results through decreased light transmission or poor color development; however, recommended pre-treatment of samples to remove turbidity and any interfering constituents (Hach Company, 2004) was not done on dry-weather screening samples because the analyses were intended to be a screening procedure. All samples were collected as unfiltered samples. For those samples that were observed to be highly turbid, an aliquot of the sample was poured into a $50-\mathrm{mL}$ glass beaker and allowed to settle for 2 minutes or longer to decrease the suspended material before being transferred to a sample cell or ampule for analysis. This less rigorous approach sometimes resulted in false positives, but detection levels were low. Laboratory procedures were put in place to reanalyze suspect samples and if high level detections were confirmed, to send the sample to the NWQL for further analysis. However, no high-level detections with suspected interference were confirmed. Samples that still had measurable results despite not having any visually observed turbidity or color were deleted and the results omitted from the statistical analyses. All deleted results were low and were at or near the detection limit.

The estimated detection limit (EDL) for the colorimetric analysis of dry-weather screening samples was determined by the manufacturer of each analysis method (Hach Company, 2004; CHEMetrics, Incorporated, 2013). A provisional MDL was determined for each dry-weather screening analyte by averaging the differences between an environmental sample result and the replicate or duplicate sample result and then rounding to the nearest 0.05 or $0.005 \mathrm{mg} / \mathrm{L}$, depending on the analyte. An MDL is the lowest concentration at which an analyte can be expected to be measured with 99-percent confidence that the concentration is above zero (U.S. Environmental Protection Agency, 1997). The dry-weather screening analyte MDL values are considered provisional because more spike samples (samples with a known concentration of analyte added) are needed than have been currently (2014) analyzed to determine an MDL value that is within the 99-percent confidence level. Analyte concentrations between the EDL and the provisional MDL for a given analyte are reported as "M" values, or concentrations that are identified but not quantified; however, for purposes of this report, numerical values for samples reported as " $\mathrm{M}$ " were included in the statistical analyses and summary statistics to better indicate the large number of low level detections for dry-weather screening analytes. Any analyte concentrations below the EDL were not included in the statistical analysis.

All analyses for FIB were done at the USGS laboratory in Lee's Summit, Mo. Fecal coliform samples were analyzed using standard plate methods according to established USGS procedures (U.S. Geological Survey, variously dated). Samples for E. coli and total coliform were analyzed using IDEXX Quanti-Tray ${ }^{\circledR}$ kits, which are a semiautomated quantification method (IDEXX Laboratories, 2009). Samples are diluted and 
placed into a Quanti-Tray ${ }^{\circledR}$ that contains 97 wells or reservoirs, then incubated for 24 hours at $37^{\circ} \mathrm{C}$. After incubation is completed, the number of cells that have turned yellow are counted to determine the most probable number (MPN) of total coliform colonies, and the number of cells that fluoresce under ultraviolet light are counted to determine the MPN of E. Coli. The MPN is determined by using a probability table to convert the number of cells to an MPN of bacteria colonies that could be expected to be counted in a water sample. The IDEXX method is considered to be a semiautomated quantification method because the bacteria colonies cannot be directly counted, but the change in color or fluorescence is used as an indicator of the approximate quantity of bacteria colonies the sample contains. Sample results are reported as the most probable number of colonies per $100 \mathrm{~mL}$ of sample (MPN/100 mL). For the purposes of this report the number of colonies per $100 \mathrm{~mL}(\mathrm{col} / 100 \mathrm{~mL}$ ) reported for traditional plate methods for bacteria enumeration is considered to be equivalent to the MPN/100 mL.

Sources of $E$. coli bacteria in streams were evaluated to identify host sources using library-dependent MST methods (Carson and others, 2001; Dombek and others, 2000). MST samples were analyzed in WY 2007 at the University of Missouri Veterinary Pathology Laboratory in Columbia, Mo., using repetitive extragenic palindromic polymerase chain reaction (rep-PCR) methods (Dombek and others, 2000; Carson and others, 2001, 2003, 2005). Rep-PCR was used to produce the isolate DNA "fingerprints" of samples and to confirm that isolates were verifiably strains of $E$. coli using geographically specific, genotypic library-based methods (Carson and others, 2003). E. coli isolated from water samples for MST analysis were compared to a host-source library of $E$. coli DNA patterns from three hosts: dogs, geese, and humans. A presumptive source of sampled bacteria is assigned through a statistical comparison of genetic markers obtained from environmental E. coli samples to genetic markers in the host-source library. The development of a host-source library specific to the Little Blue River Basin was beyond the scope of this study. A library of patterns developed for other studies in the local area (Wilkison and others, 2005, 2006) was used instead. Data were classified as human, non-human (dog and geese), and unknown. Fingerprint patterns of $E$. coli from collected water samples were compared with patterns from the host-source library for similarity using BioNumerics software, version 3.0 (Applied Maths NV, 2014). The source was designated as unknown if the sample did not have at least an 80-percent similarity to a known host group (A.C. Carson, University of Missouri Veterinary Pathology Laboratory, oral commun., 2009).

The MST samples for WY 2008 through 2013 were analyzed at the USGS OWML. Samples were received on ice at the OWML and processed in duplicate on the day of receipt using the following steps:

- the sample was logged in and assigned an identification number
- a 10- to $100-\mathrm{mL}$ aliquot of the sample was amended with an E. coli carrying plasmid for spike and recovery procedures and filtered by vacuum through a 0.4-micrometer pore-size polycarbonate filter

- the filter was transferred to a vial containing acid washed glass beads and held at $-80{ }^{\circ} \mathrm{C}$ for further analysis.

Preserved filters were extracted by use of the GeneRite DNA-EZ extraction kit according to manufacturer's instructions, with minor modifications. Extracted DNA was stored at $-20{ }^{\circ} \mathrm{C}$ until analysis by quantitative polymerase chain reaction (qPCR). The qPCR analysis steps were as follows:

- Exogenous DNA (E. coli plasmid) was measured for spike-and-recovery efficiency. If recovery efficiency was less than 50 percent, the duplicate filter was extracted and used for analysis. Matrix inhibition was measured by spiking a known quantity of plasmidborne target sequence into the reaction mixture that also contained sample DNA extract. If the detection of spiked target was less than 95 percent, the sample was considered to exert matrix inhibition on the qPCR reaction. The sample was subsequently diluted and the highest-concentration dilution that did not exert matrix inhibition on the qPCR reaction was used for test reactions.

- Host-associated markers by qPCR were analyzed by using the appropriate dilution as indicated by matrix inhibition tests:

- General fecal contamination marker (AllBac; Layton and others, 2006)

- Human-associated marker (qHF183; Seurinck and others, 2005)

- Ruminant-associated marker (BoBac; Layton and others, 2006)

- Dog-associated marker (BacCan; Kildare and others, 2007)

Full analytical methods are available on request from the OWML. Contact information can be accessed at $h t t p: / /$ oh.water.usgs.gov/micro_contact.htm.

Preserved macroinvertebrate samples were sent to the USGS NWQL for enumeration and taxonomic identification according to USGS protocols (Moulton and others, 2000 , 2002). Generally, taxa were identified by the NWQL to genus or species; however, some taxa were identified to a higher taxonomic level, typically family. Ambiguous taxa were resolved by removing the higher taxonomic level (parent) or merging the lower taxonomic level (children) with the parent. If the abundance of the ambiguous parent was higher than the sum of the children's abundances, the children were deleted and their abundances were added to the parent. If the sum of the ambiguous children's abundances was higher, the 
children were retained and the parent was deleted (Cuffney and Brightbill, 2011). This method of resolving ambiguities is conservative and may result in reduced sample richness and abundance but retains sensitivity of the data to differences in urban intensity (Cuffney and others, 2007).

\section{Quality Control and Quality Assurance}

Quality-control samples, designed to ensure the integrity of the data collected by testing all aspects of the sample collection and analysis process (U.S. Geological Survey, variously dated), consisted of about 10 percent of all waterquality samples collected during this study. Quality-assurance procedures were utilized to ensure the precision and accuracy of the water-quality data included in this report. Qualitycontrol and quality-assurance results for data collected during previous studies are included in this report and are presented in previous reports (Christensen and others, 2010; Christensen and Krempa, 2012).

Various types of quality-control samples were collected for this study, and the type of quality-control sample chosen was dependent on the type of environmental sample being collected. Field replicate samples were collected to measure the amount of variability introduced during the sample collection and analysis process. Field blanks were used to determine if any contamination was introduced by sample collection and processing. Laboratory duplicates were analyzed to determine the amount of variability introduced during laboratory processing and analysis. Laboratory blanks were analyzed to determine if laboratory processing and analysis introduced any contamination to the samples. Laboratory spikes and accuracy checks were used to measure potential bias in the sampling analysis process for OMC, MST, and dry-weather screening samples. Field and laboratory replicates and blanks were collected and analyzed for base-flow and stormflow samples. Dry-weather screening samples utilized field replicates, laboratory duplicates and blanks, and laboratory spikes and accuracy checks to test sample collection, processing, and analysis. USGS standard water-quality sampling protocols (U.S. Geological Survey, variously dated) were followed when collecting and processing field and laboratory quality-control samples.

A total of 97 constituents were analyzed as environmental and replicate or duplicate samples for quality-control analysis in base-flow and stormflow samples. All constituents with at least four matching pairs of environmental and replicate or duplicate samples, with results greater than the minimum reporting level (MRL) for each constituent, are presented in table 4. The MRL is the lowest measured concentration of a constituent that may be reliably reported (Childress and others, 1999). The MRL for each constituent analyzed by the USGS NWQL was determined by the USGS NWQL and varied with time during the study period (U.S. Geological Survey Nation Water Quality Laboratory, 2014). The average relative percent difference between the environmental sample and replicate or duplicate sample concentration for most constituents (dryweather screening samples are discussed separately) was less than 10 percent (table 4 ). There were 8 constituents with differences between 10 and 20 percent, and 3 constituents with differences greater than 20 percent. E. Coli, total coliform, and SSC had differences ranging from 22.8 to 29.2 percent (table 4). For all constituents, the highest relative percentage differences of sample pairs typically occurred at or near the MRL for a constituent.

Simple linear regression analysis was used to compare the base-flow and stormflow environmental and replicate or duplicate quality-control samples (fig. 6). Any constituent results that were less than the MRL were not included in the linear regression analysis. All measured constituents compared well with most coefficients of determination $\left(R^{2}\right)$ values greater than 0.85 ; however, total mercury had an $R^{2}$ value of 0.77 . Although OMCs also compared well with $R^{2}$ values greater than 0.85 , because there were less than 10 paired values above the MRL for each OMC constituent, they have been excluded from figure 6 .

Generally, concentrations for most constituents analyzed in blank samples were at or below the MRL, indicating that sample collection and processing procedures were not a source of bias. Many values were reported as estimated values that were between the laboratory reporting limit (LRL) and the long term method detection limit (LT-MDL; Childress and others, 1999; Zaugg and others, 2002). The NWQL LRL for a constituent is calculated as twice the LT-MDL (Childress and others, 1999); however, there were 12 detections (9 estimated) of OMCs in 5 field blank samples, and 9 detections (5 estimated) of constituents other than OMCs in 7 field blank samples (table 5). The pesticides N,N-diethyl-meta-toluamide (DEET) and benzophenone were reported at low median concentrations of 0.287 and 0.170 micrograms per liter $(\mu \mathrm{g} / \mathrm{L})$, respectively. The detergent 4-nonylphenol and the flame retardant tris (2-butoxyethyl) phosphate also were detected at low median concentrations of 0.720 and $0.267 \mu \mathrm{g} / \mathrm{L}$, respectively. The other OMCs with detections in blank samples (bisphenol A, naphthalene, and tributyl phosphate) were reported as estimated concentrations. One field blank sample had detections for chloride and ammonia, and two others had detections for total coliform; however, the detections were only slightly above the MRL for chloride and ammonia, and low for total coliform. Four field blank samples had detections for four other constituents (total sodium, ammonia, arsenic, and cyanide), which were reported as estimated concentrations.

Additional quality-assurance procedures for water-quality samples are used at the USGS NWQL to quantify and assess all aspects of sample analysis, including bias, variability, method performance, and instrument sensitivity and calibration (Maloney, 2005). Deviations from the standard procedures of the laboratory (values less than the MRL or suspected interferences, for example) are reported as estimated values by all laboratories doing analyses for this study.

Multiple dilutions of bacteria samples from Independence streams were used to ensure a count was obtained within the 
Table 4. Summary of quality-control (replicate and duplicate) sample results for selected constituents in base-flow and stormflow water-quality samples at all Independence sites, June 2006 through September 2013.

[All Independence sites from table 2, fig. 1. mg/L, milligrams per liter; N, nitrogen; P, phosphorus; E. coli, Escherichia coli; MPN, most probable number; mL, milliliter; col, colonies; $\mu$ g/L, micrograms per liter; E, environmental sample; Q, replicate or duplicate sample]

\begin{tabular}{|c|c|c|c|c|c|c|c|c|c|c|c|}
\hline Statistic & $\begin{array}{c}\text { Total } \\
\text { dissolved } \\
\text { solids }\end{array}$ & $\begin{array}{l}\text { Sodium, } \\
\text { dissolved }\end{array}$ & $\begin{array}{l}\text { Sodium, } \\
\text { total }\end{array}$ & $\begin{array}{l}\text { Chloride, } \\
\text { dissolved }\end{array}$ & $\begin{array}{c}\text { Ammonia } \\
\text { plus organic } \\
\text { nitrogen, total }\end{array}$ & $\begin{array}{l}\text { Ammonia, } \\
\text { dissolved }\end{array}$ & $\begin{array}{c}\text { Nitrate plus } \\
\text { nitrite, } \\
\text { dissolved }\end{array}$ & $\begin{array}{c}\text { Nitrate, } \\
\text { dissolved }\end{array}$ & $\begin{array}{c}\text { Nitrite, } \\
\text { dissolved }\end{array}$ & $\begin{array}{c}\text { Total } \\
\text { organic } \\
\text { nitrogen }\end{array}$ & $\begin{array}{c}\text { Ortho- } \\
\text { phosphate, } \\
\text { dissolved }\end{array}$ \\
\hline Standard error & 13.3 & 1.05 & 0.87 & 1.38 & 0.24 & 0.03 & 0.02 & 0.03 & 0.00 & 0.30 & 0.01 \\
\hline $\begin{array}{l}\text { Average relative percentage } \\
\text { difference }\end{array}$ & 3.2 & 2.0 & 1.5 & 1.1 & 5.1 & 15.8 & 2.8 & 3.1 & 11.3 & 7.3 & 8.0 \\
\hline $\begin{array}{l}\text { Median relative percentage } \\
\text { difference }\end{array}$ & 2.5 & 1.0 & 0.9 & 0.3 & 2.8 & 5.7 & 0.6 & 0.7 & 0.7 & 5.7 & 4.2 \\
\hline Number of matched pairs & 29 & 29 & 29 & 29 & 29 & 18 & 28 & 28 & 29 & 18 & 24 \\
\hline Statistic & $\begin{array}{l}\text { Phosphorus, } \\
\text { dissolved }\end{array}$ & $\begin{array}{l}\text { Phosphorus, } \\
\text { total }\end{array}$ & $\begin{array}{c}\text { Total } \\
\text { nitrogen }\end{array}$ & $\begin{array}{c}\text { E. coli } \\
\text { (MPN/100 mL) }\end{array}$ & $\begin{array}{c}\text { Fecal } \\
\text { coliform } \\
\text { (col/100 mL) }\end{array}$ & $\begin{array}{c}\text { Total } \\
\text { coliform } \\
(\mathrm{MPN} / 100 \mathrm{~mL})^{2}\end{array}$ & $\begin{array}{l}\text { Aluminum, } \\
\text { total }\end{array}$ & $\begin{array}{l}\text { Cadmium, } \\
\text { total }\end{array}$ & $\begin{array}{l}\text { Chromium, } \\
\text { total }\end{array}$ & $\begin{array}{l}\text { Copper, } \\
\text { total }\end{array}$ & $\begin{array}{l}\text { Lead, } \\
\text { total }\end{array}$ \\
\hline Standard error & 0.02 & 0.13 & 0.29 & 3,619 & 2,372 & 241,982 & 1,542 & 0.03 & 2.18 & 6.51 & 4.71 \\
\hline $\begin{array}{l}\text { Average relative percentage } \\
\text { difference }\end{array}$ & 12.7 & 5.0 & 3.1 & 29.2 & 19.6 & 25.9 & 5.5 & 4.9 & 5.0 & 8.5 & 5.5 \\
\hline $\begin{array}{l}\text { Median relative percentage } \\
\text { difference }^{3}\end{array}$ & 4.0 & 1.9 & 1.1 & 26.1 & 16.7 & 22.2 & 2.1 & 4.3 & 2.9 & 4.1 & 1.1 \\
\hline Number of matched pairs & 25 & 27 & 28 & 25 & 16 & 25 & 29 & 16 & 22 & 21 & 29 \\
\hline Statistic & $\begin{array}{l}\text { Mercury, } \\
\text { total }\end{array}$ & $\begin{array}{l}\text { Zinc, } \\
\text { total }\end{array}$ & $\begin{array}{c}\text { Arsenic, } \\
\text { total }\end{array}$ & $\begin{array}{l}\text { Suspended } \\
\text { sediment }\end{array}$ & $\begin{array}{l}\text { Atrazine, } \\
\text { total }\end{array}$ & $\begin{array}{c}\text { Carbazole, } \\
\text { total }\end{array}$ & $\begin{array}{c}\text { Total } \\
N, N \text {-diethyl- } \\
m \text {-toluamide } \\
\text { (DEET) }\end{array}$ & $\begin{array}{l}\text { Caffeine, } \\
\text { total }\end{array}$ & $\begin{array}{l}\text { Pyrene, } \\
\text { total }\end{array}$ & & \\
\hline Standard error & 0.02 & 15.3 & 0.40 & 100.0 & 0.03 & 0.01 & 0.07 & 0.03 & 0.07 & & \\
\hline $\begin{array}{l}\text { Average relative percentage } \\
\text { difference }{ }^{3}\end{array}$ & 13.0 & 5.7 & 5.0 & 22.8 & 17.1 & 7.0 & 13.1 & 9.7 & 19.0 & & \\
\hline $\begin{array}{l}\text { Median relative percentage } \\
\text { difference }^{3}\end{array}$ & 6.6 & 2.2 & 2.9 & 17.3 & 18.1 & 6.5 & 7.7 & 9.0 & 20.8 & & \\
\hline Number of matched pairs & 13 & 25 & 29 & 37 & 4 & 3 & 9 & 4 & 4 & & \\
\hline
\end{tabular}

${ }^{1}$ Total nitrogen equals ammonia plus nitrite plus nitrate plus organic nitrogen.

${ }^{2}$ For the purposes of this report, most probable number per 100 milliliters is considered to be comparable to colonies per 100 milliliters.

${ }^{3}$ Relative percentage differences are calculated from data that may contain values that are estimated. Values less than the minimum reporting level were not included in the statistical analysis. Relative percent difference $=[(E-Q) * 100] /[(E+Q) / 2]$. 

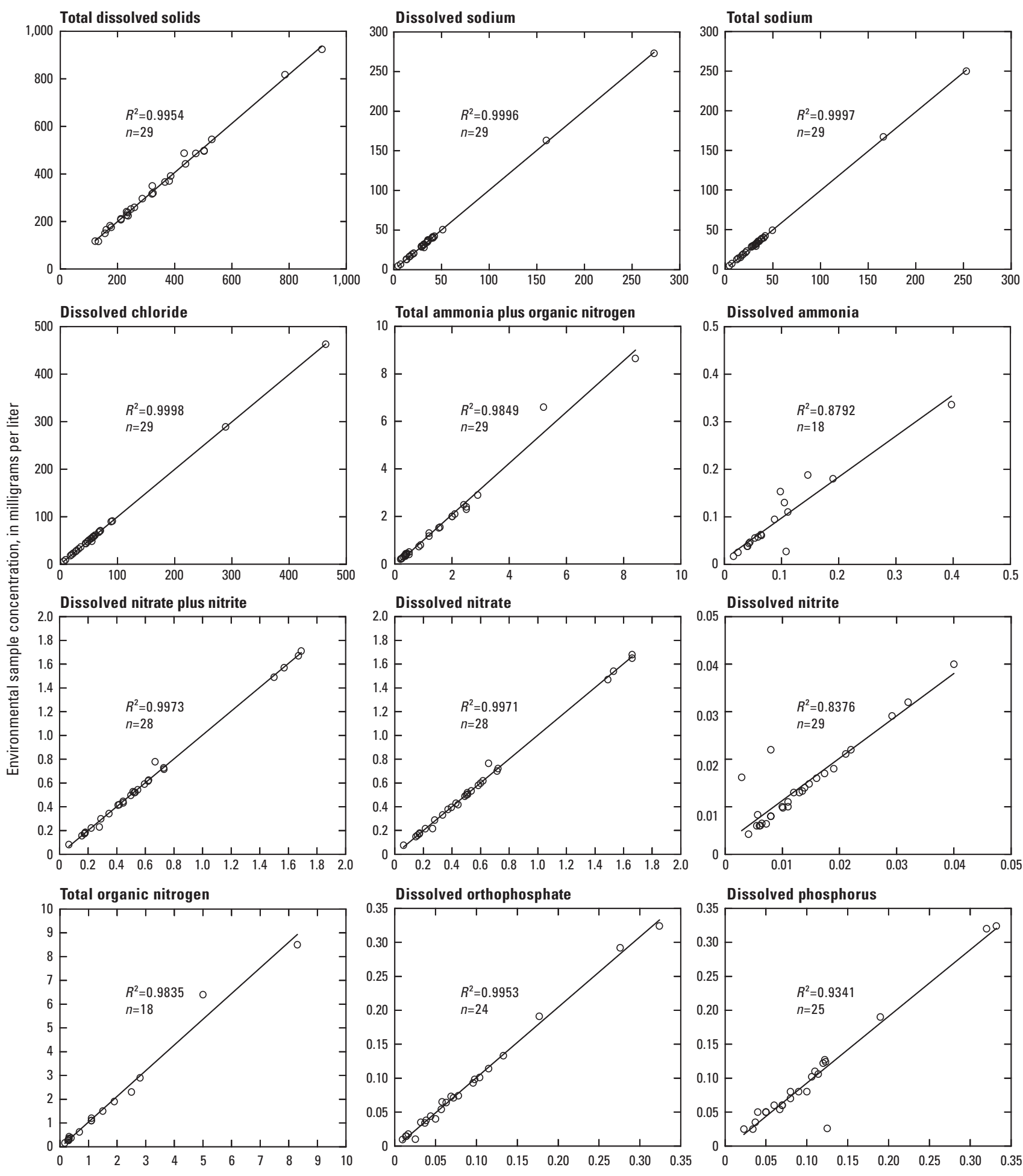

Replicate or duplicate sample concentration, in milligrams per liter

EXPLANATION

$R^{2}$ Coefficient of determination

$n \quad$ Number of replicate and duplicate pairs-Values may overlap

Figure 6. Quality-assurance data for nutrients and select constituents in field replicate or laboratory duplicate sample pairs. 

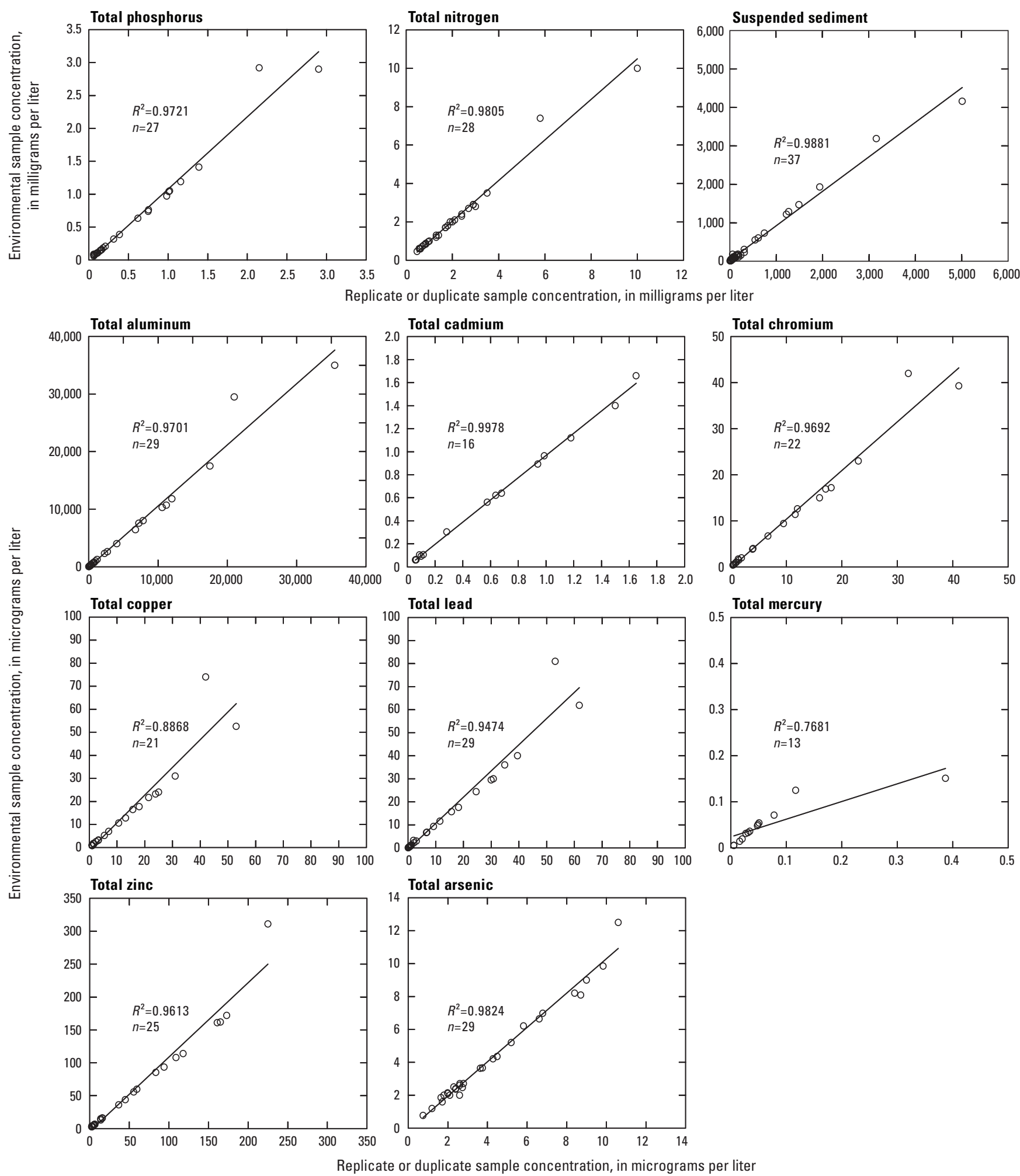

\section{EXPLANATION}

$R^{2}$ Coefficient of determination

$n \quad$ Number of replicate and duplicate pairs-Values may overlap

Figure 6. Quality-assurance data for nutrients and select constituents in field replicate or laboratory duplicate sample pairs. -Continued 
Table 5. Summary of detections of selected water-quality constituents and common organic micro-constituents in blank water samples at all Independence sites, June 2005 through September 2013.

[All Independence sites from table 2, fig. 1. mg/L, milligrams per liter; N, nitrogen; MPN, most probable number; mL, milliliters; $\mu \mathrm{g} / \mathrm{L}$, micrograms per liter; --, not sampled; LT-MDL, long term method detection level; na, not available]

\begin{tabular}{|c|c|c|c|c|c|c|c|c|c|c|c|c|c|}
\hline \multirow[b]{2}{*}{ Statistic } & \multicolumn{6}{|c|}{ Other selected constituents } & \multicolumn{7}{|c|}{ Common organic micro-constituents } \\
\hline & $\begin{array}{l}\text { Total } \\
\text { sodium } \\
\text { (mg/L) }\end{array}$ & $\begin{array}{l}\text { Chloride, } \\
\text { dissolved } \\
\text { (mg/L) }\end{array}$ & $\begin{array}{c}\text { Ammonia, } \\
\text { dissolved } \\
\text { (mg/L as } N)\end{array}$ & $\begin{array}{c}\text { Total } \\
\text { coliform } \\
(\mathrm{MPN} / 100 \mathrm{~mL})^{1}\end{array}$ & $\begin{array}{c}\text { Arsenic, } \\
\text { total } \\
\text { ( } \mu \mathrm{g} / \mathrm{L})\end{array}$ & $\begin{array}{c}\text { Cyanide, } \\
\text { (mg/L) }\end{array}$ & $\begin{array}{c}\text { Total } \\
\text { N,N-diethyl- } \\
\text { m-toluamide } \\
\text { (DEET) } \\
\text { ( } \mathrm{gg} / \mathrm{L})\end{array}$ & $\begin{array}{c}\text { Total } \\
\text { 4-nonyl- } \\
\text { phenol } \\
(\mu \mathrm{g} / \mathrm{L})\end{array}$ & $\begin{array}{c}\text { Total } \\
\text { benzo- } \\
\text { phenone } \\
\text { ( } \mu \mathrm{g} / \mathrm{L})\end{array}$ & $\begin{array}{c}\text { Total } \\
\text { bisphenol A } \\
(\mu \mathrm{g} / \mathrm{L})\end{array}$ & $\begin{array}{c}\text { Total } \\
\text { naphthalene } \\
(\mu \mathrm{g} / \mathrm{L})\end{array}$ & $\begin{array}{c}\text { Total } \\
\text { tributyl } \\
\text { phosphate } \\
(\mu \mathrm{g} / \mathrm{L})\end{array}$ & $\begin{array}{c}\text { Total } \\
\text { tris(2- } \\
\text { butoxyethyl) } \\
\text { phosphate } \\
(\mu \mathrm{g} / \mathrm{L})\end{array}$ \\
\hline Samples $^{2}$ & 8 & 8 & 8 & 6 & 8 & 7 & 5 & 5 & 5 & 5 & 5 & 5 & 5 \\
\hline Detections $^{3}$ & 1 & 1 & 2 & 2 & 1 & 2 & 3 & 1 & 3 & 1 & 2 & 1 & 1 \\
\hline Minimum $^{4}$ & 0.06 & 0.141 & 0.01 & 3 & 0.10 & 0.003 & 0.020 & 0.720 & 0.090 & 0.007 & 0.063 & 0.037 & 0.267 \\
\hline Maximum $^{4}$ & -- & -- & 0.02 & 7 & -- & 0.005 & 0.359 & -- & 0.300 & -- & 0.100 & -- & -- \\
\hline Average $^{4}$ & -- & -- & 0.01 & 5 & -- & 0.004 & 0.222 & -- & 0.187 & -- & 0.082 & -- & -- \\
\hline Median $^{4}$ & -- & -- & 0.01 & 5 & -- & 0.004 & 0.287 & -- & 0.170 & -- & 0.082 & -- & -- \\
\hline LT-MDL & 0.12 & 0.04 & 0.02 & 1 & 0.40 & na & 0.04 & 1.6 & 0.08 & 0.04 & 0.220 & 0.064 & 0.640 \\
\hline
\end{tabular}

${ }^{1}$ For the purposes of this report, most probable number per 100 milliliters is considered to be comparable to colonies per 100 milliliters.

${ }^{2}$ Number of samples analyzed for each selected constituent or common organic micro-constituent.

${ }^{3}$ Number of samples with detections of each selected constituent or common organic micro-constituent.

${ }^{4}$ Minimum, maximum, average, and median values are calculated from data that may contain values that are estimated. Values less than the minimum reporting level were not included in the statistical analysis. 

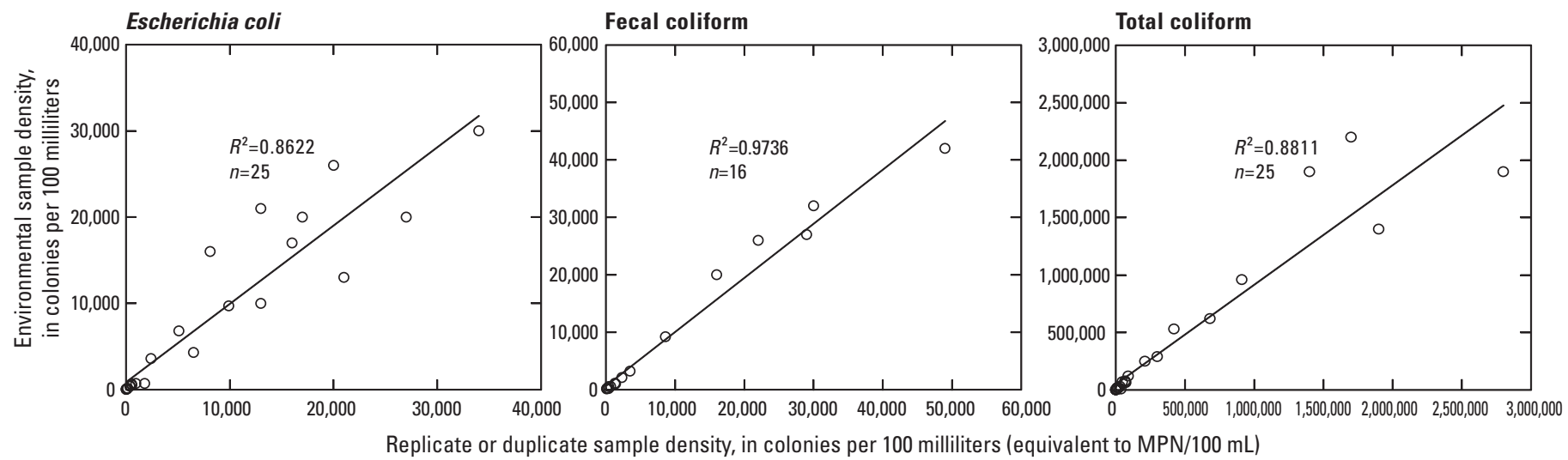

EXPLANATION

$R^{2}$ Coefficient of determination

$n$ Number of replicate and duplicate

pairs-Values may overlap

Figure 7. Quality-assurance data for fecal indicator bacteria in field replicate or laboratory duplicate sample pairs.

optimal range for reporting bacteria densities. Standard USGS procedures were used to estimate any bacteria concentrations outside the optimal range (U.S. Geological Survey, variously dated). Replicate samples also were collected and enumerated for FIB. Bacteria replicates compared well with $R^{2}$ values of 0.86 for E. Coli, 0.97 for fecal coliform, and 0.88 for total coliform (fig. 7).

Samples for MST collected in WY 2007 were quality assured by comparing $E$. coli samples originating from dogs, geese, and humans to those in the geographically specific genotype library. Samples from known sources in the geographically specific genotype library were updated biannually. If the samples were correctly identified, then the library was considered to still be valid (A.C. Carson, oral commun., 2009).

Laboratory quality-control samples for MST samples collected from WY 2008 through WY 2013 included filtration blanks, extraction blanks, and no-template controls. Low-level detections of MST markers less than the laboratory determined level of quantification were present in a small number of blank samples. These detections were used to determine the lower detection limits for each marker. Average blank concentrations by laboratory sample run and method are presented in table 6 .

Quality assurance for each sample run included the following processes or procedures:

1. All analyses were done in duplicate.

2. Each analytical run included a 6-point standard curve and an analysis blank (no-template control).

3. Each filtration run included a procedure blank with the addition of spike-and-recovery control.

4. Each extraction run included an extraction blank to test for cross contamination.
To guard against false-positive results, a detection threshold was established for each qPCR method. The level of detection (LoD) was defined as the 95-percent confidence interval around the detections on blank samples. Results for samples that register the presence of a constituent lower than the upper range observed for blank samples are reported as below detection limit (bdl); however, low-level quantification can be unreliable. To guard against interpretation of unreliable results, a level of quantification (LoQ) was established based on the lowest concentration that is reliably detected for each qPCR method. Results for samples that register the presence of bacterial DNA higher than the upper range observed for blank samples, but lower than the quantification limit, are reported as detected not quantified (dnq) and the estimated concentration value is provided. In addition, eight quality-control field sample replicates were collected (table 7).

Simple linear regression analysis was used to compare the dry-weather screening environmental and quality-control samples (fig. 8). Any sample results below the MRL for a constituent were not included in the statistical analysis. Three of the four constituents analyzed (total chlorine, phenols, and anionic surfactants) show high correlation, with $R^{2}$ values of $0.99,0.90$, and 0.98 , respectively. All three, however, had one outlying sample pair with a higher concentration than the other sample pairs. When these outlying pairs are removed from the regression data, anionic surfactants still exhibit high correlation $\left(R^{2}=0.90\right)$ and chlorine shows moderate correlation $\left(R^{2}=0.48\right)$, but phenols show low correlation $\left(R^{2}=0.02\right)$. These lower correlations indicate that the reproducibility of chlorine and phenols analyses decreases at low concentrations. Most (67 percent) of the total dissolved copper analyses were at or below the provisional MRL $(0.04 \mathrm{mg} / \mathrm{L})$ and total dissolved copper analyses showed poor correlation, with an $R^{2}$ value of 0.02 The recovery values for spike samples of total dissolved copper were generally less than 10 percent of full recovery 
Table 6. Average blank sample concentrations for microbial source tracking samples by initial sample collection date and batch processing data group.

[copies/100 mL, copies per 100 milliliters; B. Theta, Bacteroides thetaiotaomicron; NTC, no-template control qPCR blank; --, no data; Filtration, filtration blank; Extraction, extraction blank; LoD, level of detection; LoQ, level of quantification]

\begin{tabular}{|c|c|c|c|c|c|}
\hline Blank type & $\begin{array}{c}\text { AllBac }^{1} \\
\text { copies/100 mL } \\
\text { (number of blanks) }\end{array}$ & $\begin{array}{c}\text { HF183 }^{2} \\
\text { copies/100 mL } \\
\text { (number of blanks) }\end{array}$ & $\begin{array}{c}\text { B. Theta } \\
\text { copies/100 mL } \\
\text { (number of blanks) }\end{array}$ & $\begin{array}{c}\text { BacCan }^{4} \\
\text { copies/100 mL } \\
\text { (number of blanks) }\end{array}$ & $\begin{array}{c}\text { BoBac }^{5} \\
\text { copies/100 mL } \\
\text { (number of blanks) }\end{array}$ \\
\hline \multicolumn{6}{|c|}{ 6/13/2008-9/23/2008 } \\
\hline NTC & $60(2)$ & $1(2)$ & $1(1)$ & $9(2)$ & -- \\
\hline Filtration & $134(9)$ & $1(9)$ & $1(9)$ & $9(9)$ & -- \\
\hline Extraction & $113(4)$ & $1(11)$ & $1(4)$ & $9(2)$ & -- \\
\hline \multicolumn{6}{|c|}{ 10/22/2008-8/19/2009 } \\
\hline NTC & $44(2)$ & $1(2)$ & $1(2)$ & $9(2)$ & -- \\
\hline Filtration & $336(14)$ & $5(14)$ & $1(14)$ & $18(14)$ & -- \\
\hline Extraction & $239(4)$ & $2(4)$ & $1(4)$ & $14(4)$ & -- \\
\hline \multicolumn{6}{|c|}{$3 / 4 / 2010-9 / 1 / 2010$} \\
\hline \multicolumn{6}{|c|}{ 11/3/2010-8/19/2011 } \\
\hline NTC & $50(2)$ & $1(2)$ & -- & $9(2)$ & $51(2)$ \\
\hline Filtration & $115(12)$ & $2(12)$ & -- & $10(12)$ & $92(12)$ \\
\hline Extraction & $109(3)$ & $1(3)$ & -- & $9(3)$ & $51(3)$ \\
\hline \multicolumn{6}{|c|}{ 9/15/2011-6/11/2012 } \\
\hline NTC & $44(3)$ & $1(3)$ & -- & $9(2)$ & $53(3)$ \\
\hline Filtration & $70(11)$ & $71(9)$ & -- & $20(8)$ & $68(11)$ \\
\hline Extraction & $70(4)$ & $102(4)$ & -- & $11(3)$ & $57(4)$ \\
\hline \multicolumn{6}{|c|}{ 11/29/2012-9/19/2013 } \\
\hline
\end{tabular}

${ }^{1}$ AllBac, assay for general fecal contamination (Layton and others, 2006).

${ }^{2} \mathrm{qHF} 183$, assay for human-associated fecal contamination (Seurinck and others, 2005).

${ }^{3} B$. Theta, assay for human-associated fecal contamination (Carson and others, 2005).

${ }^{4} \mathrm{BacCan}$, assay for canine-associated fecal contamination (Kildare and others, 2007).

${ }^{5} \mathrm{BoBac}$, assay for ruminant-associated fecal contamination (Layton and others, 2006).

(data on file at the USGS Water Science Center office in Lee's Summit). Total dissolved copper analyses were discontinued during the 2011 WY. Spike sample analyses for each dry-weather screening analyte (total chlorine, total dissolved copper, phenols, and anionic surfactants) were done before and at the conclusion of each annual sampling period by the same technicians who analyzed the environmental samples. Dry-weather screening results in this report are considered to be semiquantitative.
Given collection, identification, and enumeration constraints, replicates for macroinvertebrate samples were not collected. Macroinvertebrate sample collection and enumeration are expensive, labor intensive, and time consuming. The MDNR determined that collection of an additional macroinvertebrate sample from a different reach of the same stream improved impairment detection by only 9.3 percent (Rabeni and others, 1997) and when duplicate samples were analyzed 
Table 7. Microbial source tracking replicate sample pairs.

[Sample ID, laboratory identification number; E. coli, Escherichia coli; MPN/100 mL, most probable number per 100 milliliters; copies/100 mL, copies per 100 milliters; B. Theta, Bacteroides thetaiotaomicron; S, stormflow; --, no data; nd, not detected; na, not available (sample not collected); <, less than; bdl, below detection limit; B, base flow; dnq, concentration is below the limit of quantification but above the limit of detection; E, estimated; $\sim$, duplicate qPCR results do not agree]

\begin{tabular}{|c|c|c|c|c|c|c|c|c|c|c|c|c|c|c|c|}
\hline $\begin{array}{c}\text { Sample } \\
\text { ID }\end{array}$ & Date & $\begin{array}{c}\text { Site number } \\
\text { (table 2, } \\
\text { fig. 1) }\end{array}$ & Flow & $\begin{array}{c}\text { E. coli } \\
\text { (MPN/ } \\
100 \mathrm{~mL} \text { ) }\end{array}$ & $\begin{array}{c}\text { E. coli } \\
\text { remarks }\end{array}$ & $\begin{array}{c}\text { AllBac }^{1} \\
\text { (copies/ } \\
100 \mathrm{~mL} \text { ) }\end{array}$ & $\begin{array}{c}\text { AllBac } \\
\text { remarks }\end{array}$ & $\begin{array}{c}\text { HF1832 }^{2} \\
\text { (copies/ } \\
100 \mathrm{~mL} \text { ) }\end{array}$ & $\begin{array}{c}\text { HF183 } \\
\text { remarks }\end{array}$ & $\begin{array}{c}\text { B. Theta } \\
\text { (copies/ } \\
100 \mathrm{~mL} \text { ) } \\
\end{array}$ & $\begin{array}{l}\text { B. Theta } \\
\text { remarks }\end{array}$ & $\begin{array}{c}\text { BacCan }^{4} \\
\text { (copies/ } \\
100 \mathrm{~mL} \text { ) } \\
\end{array}$ & $\begin{array}{l}\text { BacCan } \\
\text { remarks }\end{array}$ & $\begin{array}{c}\text { BoBac }^{5} \\
\text { (copies/ } \\
100 \mathrm{~mL} \text { ) }\end{array}$ & $\begin{array}{c}\text { BoBac } \\
\text { remarks }\end{array}$ \\
\hline $1330-02$ & $11 / 6 / 2008$ & 7 & $\mathrm{~S}$ & 30,000 & -- & $23,100,000$ & -- & 11,200 & -- & -- & nd & 48,100 & -- & na & na \\
\hline $1330-03$ & $11 / 6 / 2008$ & 7 & $\mathrm{~S}$ & -- & -- & $19,400,000$ & -- & 19,800 & -- & $<5,070$ & bdl & 56,700 & -- & na & na \\
\hline 1521-04 & $6 / 30 / 2009$ & 5 & B & na & na & 949,000 & -- & $<2,240$ & bdl & -- & nd & $<3,120$ & bdl & na & na \\
\hline $1521-05$ & $6 / 30 / 2009$ & 5 & B & na & na & 637,000 & -- & $<2,240$ & bdl & -- & nd & $<3,120$ & bdl & na & na \\
\hline 1538-05 & $7 / 12 / 2009$ & 9 & $\mathrm{~S}$ & 13,000 & -- & $9,280,000$ & -- & 37,300 & dnq & -- & nd & $<31,200$ & bdl & na & na \\
\hline $1538-06$ & $7 / 12 / 2009$ & 9 & $\mathrm{~S}$ & -- & -- & $10,700,000$ & -- & $<22,400$ & bdl & $<30,400$ & bdl & 139,000 & $\mathrm{E} \sim$ & na & na \\
\hline $1712-06$ & $4 / 20 / 2010$ & 2 & B & 140 & -- & $8,500,000$ & -- & $<5,600$ & bdl & -- & nd & $<15,600$ & bdl & na & na \\
\hline $1712-07$ & $4 / 20 / 2010$ & 2 & B & -- & -- & $7,900,000$ & -- & 3,730 & -- & -- & nd & $<1,560$ & bdl & na & na \\
\hline $1726-06$ & $5 / 19 / 2010$ & 3 & $\mathrm{~S}$ & 1,200 & -- & $2,990,000$ & -- & 6,920 & dnq & -- & nd & 6,880 & -- & na & na \\
\hline $1726-07$ & $5 / 19 / 2010$ & 3 & $\mathrm{~S}$ & -- & -- & $5,250,000$ & -- & 9,380 & -- & -- & nd & 21,700 & -- & na & na \\
\hline $1760-07$ & $7 / 20 / 2010$ & 7 & B & 650 & -- & $8,870,000$ & -- & $<2,800$ & bdl & -- & nd & $<3,900$ & bdl & na & na \\
\hline $1760-08$ & $7 / 20 / 2010$ & 7 & B & -- & -- & $11,300,000$ & -- & $<2,800$ & bdl & -- & nd & $<3,900$ & bdl & na & na \\
\hline $1789-01$ & $9 / 1 / 2010$ & 9 & $\mathrm{~S}$ & 20,000 & -- & $14,100,000$ & -- & 152,000 & dnq & -- & nd & $<62,400$ & bdl & na & na \\
\hline 1789-02 & $9 / 1 / 2010$ & 9 & $\mathrm{~S}$ & -- & -- & $13,600,000$ & -- & $<112,000$ & bdl & -- & nd & $<156,000$ & bdl & na & na \\
\hline 1948-01 & $8 / 19 / 2011$ & 3 & $\mathrm{~S}$ & 16,000 & -- & $27,300,000$ & -- & 27,600 & -- & na & na & 7,280 & dnq & 6,650 & -- \\
\hline 1948-02 & 8/19/2011 & 3 & $\mathrm{~S}$ & 8,100 & -- & $10,300,000$ & -- & 27,600 & -- & na & na & $<3,900$ & bdl & 4,280 & $\mathrm{E} \sim$ \\
\hline
\end{tabular}

${ }^{1}$ AllBac, assay for general fecal contamination (Layton and others, 2006).

${ }^{2} \mathrm{qHF} 183$, assay for human-associated fecal contamination (Seurinck and others, 2005).

${ }^{3} B$. Theta, assay for human-associated fecal contamination (Carson and others, 2005).

${ }^{4} \mathrm{BacCan}$, assay for canine-associated fecal contamination (Kildare and others, 2005).

${ }^{5}$ BoBac, assay for ruminant-associated fecal contamination (Layton and others, 2006). 


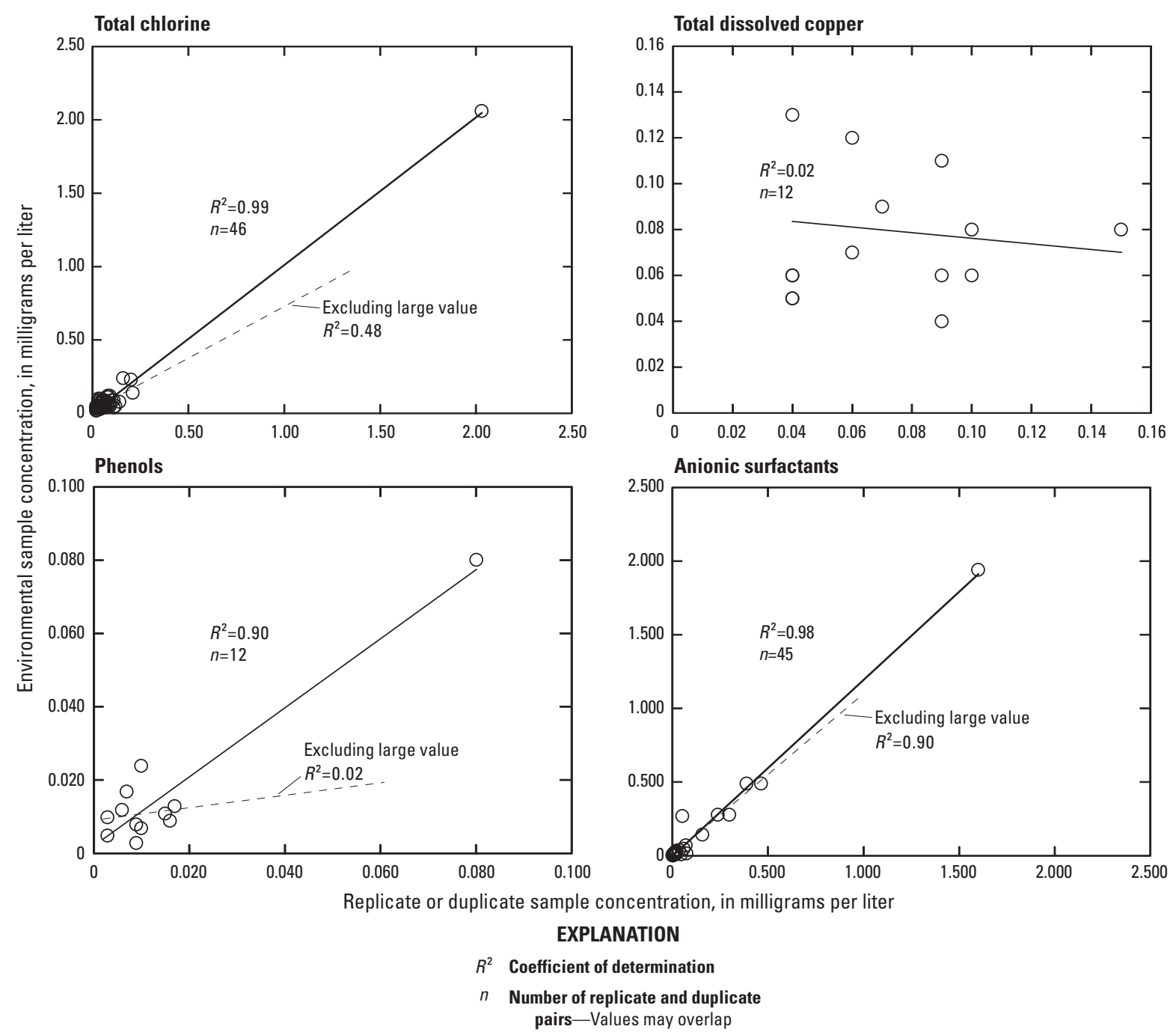

Figure 8. Quality-assurance data for dry-weather screening samples in field replicate or laboratory duplicate sample pairs.

they were identified to the same impairment category 95 percent of the time (Sarver and others, 2002). Therefore, a taxon-based approach to quality control and quality assurance was used at the USGS NWQL (Grotheer and others, 2000; Moulton and others, 2000, 2002). Quality-assurance measures included repeat identification of new specimens by a different taxonomist and random reviews for a minimum of 10 percent of all identifications.

Taxonomic identifications at the NWQL laboratory were compared to the Integrated Taxonomic Information System (ITIS) database. Taxa listed as invalid or not found in the IT IS database were either corrected or flagged and alternative authority noted. Taxonomic keys and specimens are maintained at the USGS NWQL in Lakewood, Colo. Additional information on quality-control and quality-assurance procedures for data presented in this report can be found in Christensen and Krempa (2012), and for the USGS NWQL at $h t t p: / /$ nwql.usgs.gov/Public/quality.shtml.
The accuracy and comparability of biotic indices and other tolerance-based metrics rely on the assigned tolerance values. Tolerance values from published sources generally are used, including Hilsenhoff $(1977,1988)$, Huggins and Moffet (1988), Lenat (1993), Bode and others (2002), and Klemm and others (2002). State and national listings may vary because some tolerance values are regionally adjusted to better represent local tolerance. Tolerance values are less accurate when applied to streams outside of the geographic area from which the values were established (Blocksom and Winters, 2006). Missouri's taxa tolerance listing uses values that are representative and applicable to the study area and continues to be refined (Sarver, 2005); therefore, tolerance values from the Missouri taxa listings (Sarver, 2005) were used, or if unavailable, assigned from established regional tolerance values (Cuffney and Brightbill, 2011). Greater than 93 percent of identified taxa in samples were assigned tolerance values (table 8, http://pubs.usgs.gov/ds/0915/downloads/ ds915_table08.xlsx). 


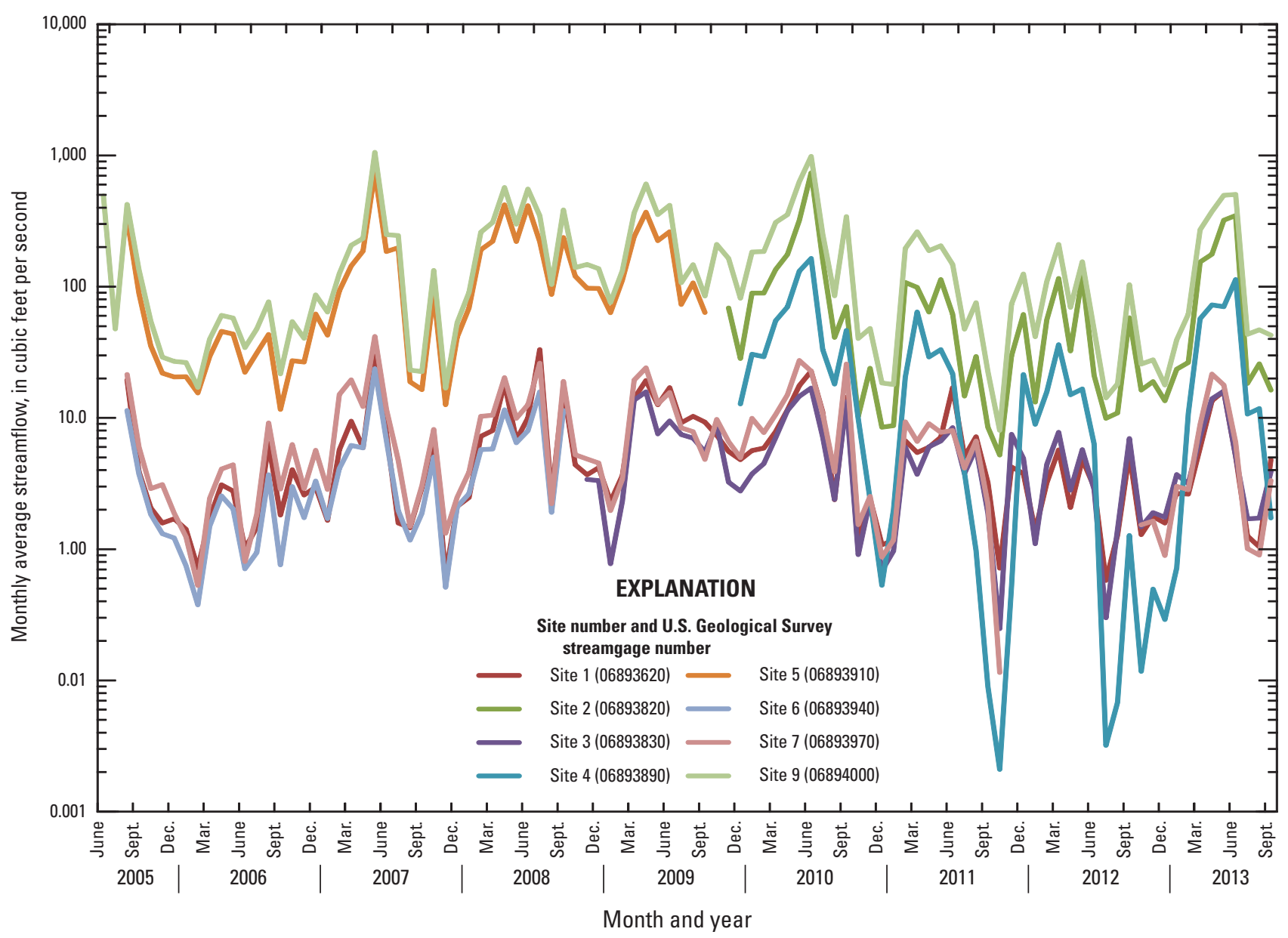

Figure 9. Monthly average streamflow by site, June 2005 through September 2013.

\section{Water-Quality Data}

Water-quality data for Independence streams were collected from base-flow and stormflow samples at eight streamgage sites (sites 1 through 7 and 9; table 2; fig. 1) and from two ungaged sites (sites 8 and 11). Physical and chemical properties, TDS, sodium, chloride, nutrients, metals, OMCs, pesticides in streambed sediment and surface water, FIB, MST, and SSC data were collected. Dry-weather screening was done within the boundaries of each of the stream basins in Independence to identify possible contamination from point source discharges.

\section{Continuous Streamflow and Water-Quality Measurements}

Continuous water-quality data were collected at eight streamgage sites (sites 1 through 7 and 9; table 2; fig. 1) over various time periods during the study. From July 2005 through September 2013, continuous streamflow data were collected at sites 1, 7, and 9. Continuous streamflow data were collected at sites 5 and 6 beginning in July 2005, but were discontinued in WY 2009 at site 5 and in WY 2008 at site 6. Continuous streamflow data were collected at site 2 from October 2009 through September 2013, at site 3 from October 2008 through September 2013, and at site 4 from November 2009 through September 2013.

Monthly average streamflow was calculated for the eight streamgages (sites 1 through 7 and 9; table 2; fig. 1), and varied from $0.02 \mathrm{ft}^{3} / \mathrm{s}$ at site 4 in October 2011 to $1,055 \mathrm{ft}^{3} / \mathrm{s}$ at site 9 in May 2007 (fig. 9). Streamflow at all sites was lowest during the fall (August through November) of 2011 and summer (July through August) of 2012.

Annual and monthly precipitation for WY 2006 were lower than in any other year from 2005 to 2013 . The precipitation measured at NWS cooperative station 234158 (fig. 1) in Independence during CY 2006 was $66.6 \mathrm{~cm}$. All other years from CY 2005 to CY 2013 measured from $75.5 \mathrm{~cm}$ to $145.9 \mathrm{~cm}$ (National Climatic Data Center, 2014a). The percentage deviations of precipitation and streamflow at Lake City (site 9; table 2; fig. 1) during the study period as compared with the 27-year average indicate there is a strong positive correlation between local precipitation and streamflow (fig. 10). The CYs 2005, 2006, 2011, and 2012 had less than average precipitation and streamflow than the 27 -year average (with 


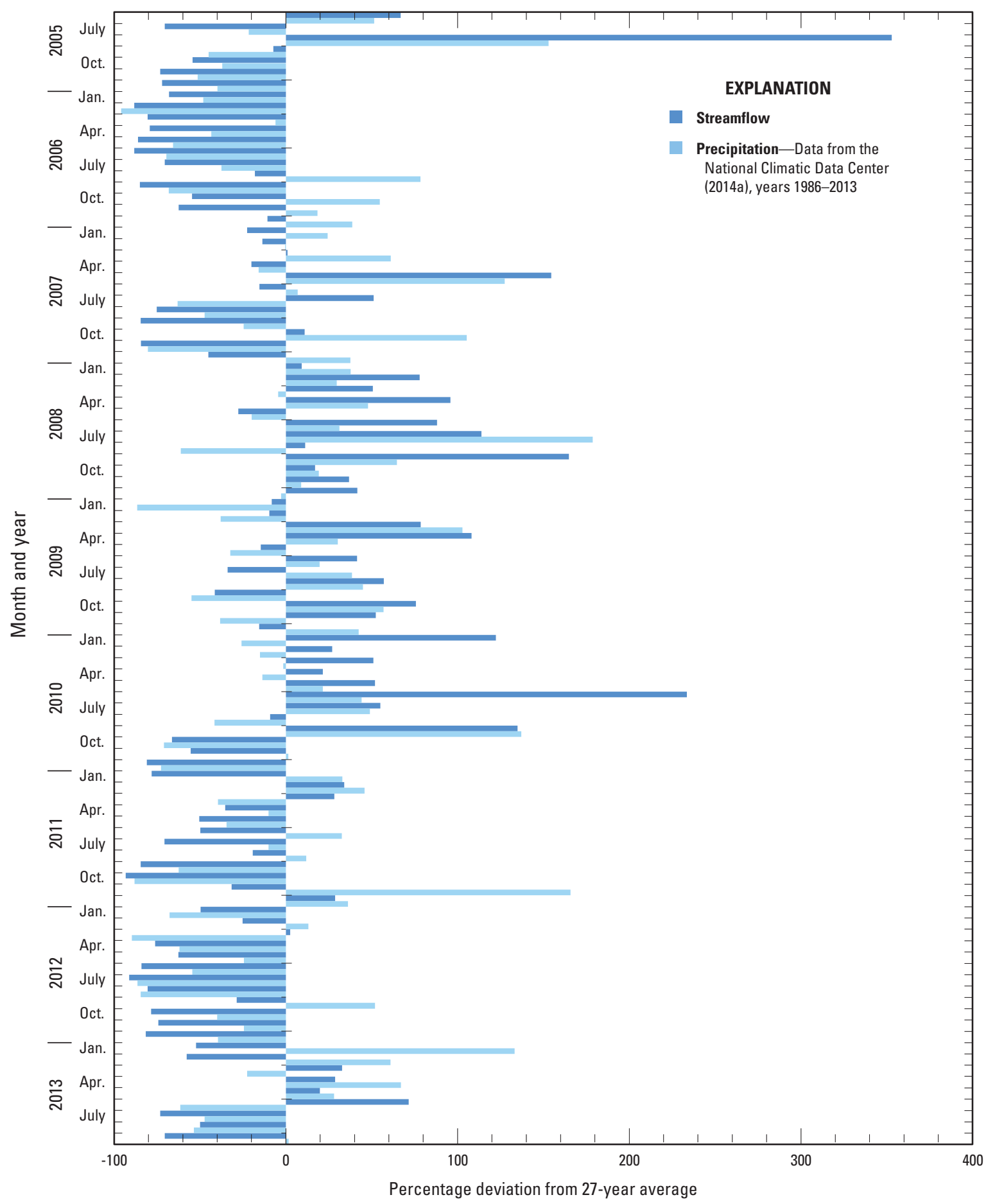

Figure 10. Percentage deviations from the 27-year monthly average streamflow at Little Blue River near Lake City, Missouri, compared with the 27-year monthly average precipitation measured and recorded at Independence, Missouri, June 2005 through September 2013.

the exception of August 2005 and November 2011), whereas most months from CYs 2008 through 2010 had greater than average precipitation and streamflow. The CYs 2007 and 2013 were divided between months of lower than average and higher than average precipitation and streamflow.
Seven sites (sites 1 through 5, 7 and 9; table 2; fig. 1) were equipped with CWQMs either for part or all of the study period. Sites 5, 7, and 9 were installed at the beginning of the study period in July 2005. Site 5 was discontinued and the CWQM removed in October 2009. Site 7 suffered from frequent shallow water depths and severe sediment deposition, 

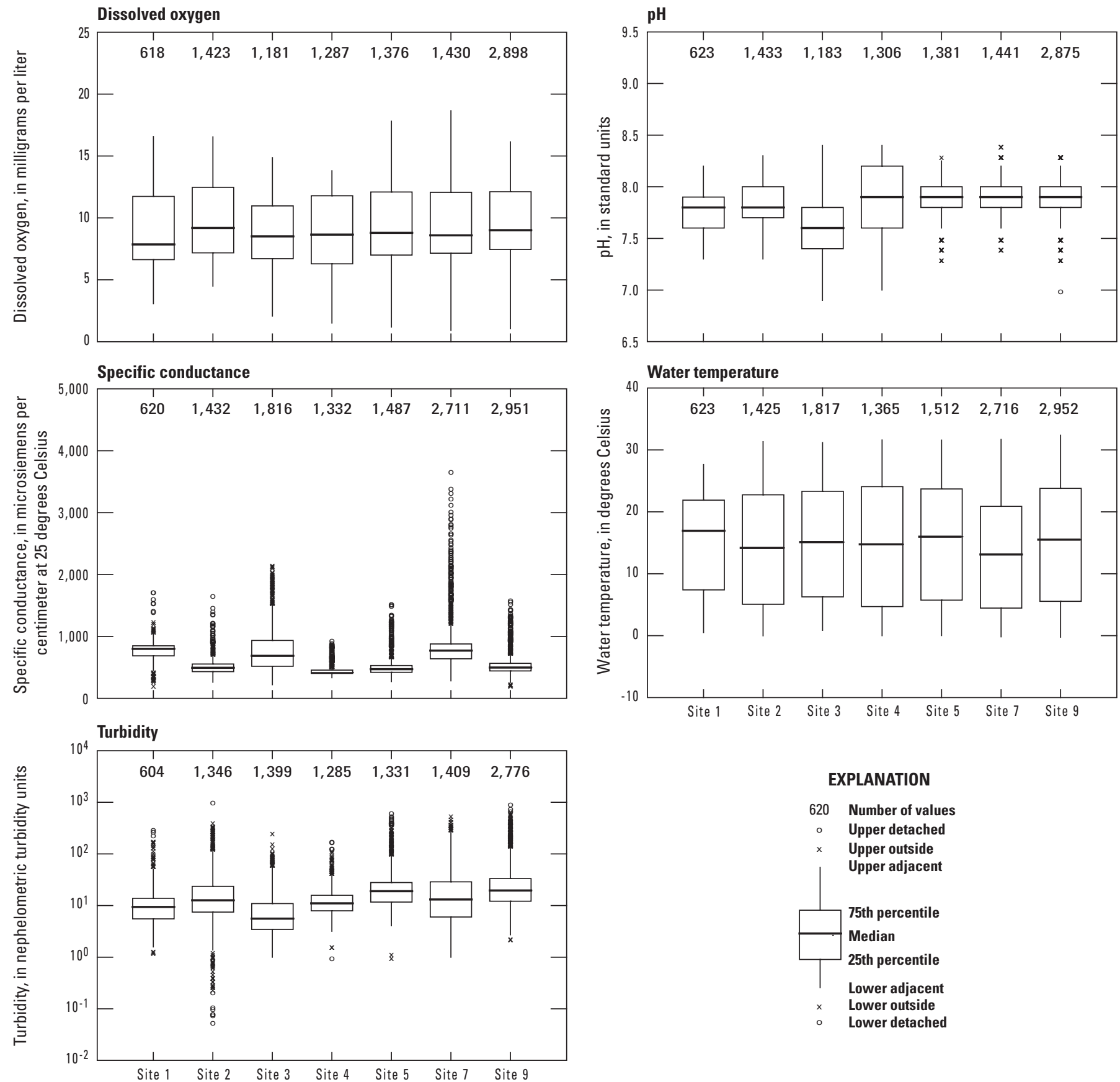

Figure 11. Boxplots of computed daily average values of dissolved oxygen, $\mathrm{pH}$, specific conductance, water temperature, and turbidity at continuous water-quality monitoring sites in Independence, Missouri.

forcing the relocation of the streamgage and CWQM downstream in August 2007. The CWQM was repositioned closer to the bank in November 2009, and the culvert was replaced in November 2010. The CWQM at site 7 was also temporarily discontinued from June to November 2010. Sites 1 through 4 were installed in December 2011 (site 1), October 2009 (site 2), October 2008 (site 3), and December 2009 (site 4). Dissolved oxygen, $\mathrm{pH}$, specific conductance, water temperature, and turbidity were recorded in 15-minute intervals. The sensors installed at each site varied during the course of the study period. Beginning with CWQM installation and through the end of the study period in September 2013, sites 1, 2, and 4 had all sensors installed (dissolved oxygen, $\mathrm{pH}$, specific conductance, water temperature, and turbidity). The sensors for dissolved oxygen, $\mathrm{pH}$, and turbidity were removed from site 3 in January 2012 and turbidity was reinstated in December 2012 (WY 2013). Site 7 recorded all values until November 2008 , only specific conductance and water temperature 
from November 2008 until January 2010 and from November 2010 to September 2012, and then all sensors were reinstated from October 2012 to September 2013. Daily values were computed from the measured data and the summarized data are presented by site in the boxplots in figure 11 .

For streams such as the Little Blue River that are designated as warm-water fisheries in Missouri, the MDNR standard for AQL for dissolved oxygen is $5 \mathrm{mg} / \mathrm{L}$ or greater (Missouri Department of Natural Resources, 2014b). This standard was used to determine compliance of dissolved oxygen on streams equipped with CWQMs. Daily average dissolved oxygen concentrations were at or below $5 \mathrm{mg} / \mathrm{L}$ less than 1 percent of the time for the Little Blue River sites (sites 2, 5, and 9; fig. 12) and nearly 10 percent of the time for site 4 . Daily average dissolved oxygen values ranged from a minimum of $0.9 \mathrm{mg} / \mathrm{L}$ to a maximum of $18.6 \mathrm{mg} / \mathrm{L}$ (fig. 11 , 12), both recorded at site 7 .

The $\mathrm{pH}$ of surface water typically ranges from 6.5 to 8.5 standard units (Hem, 1992). The $\mathrm{pH}$ standards for AQL as set forth by the MDNR require that the $\mathrm{pH}$ of surface waters not be outside a range of 6.5 to 9.0 standard units (Missouri Department of Natural Resources, 2014b). No daily values for $\mathrm{pH}$ in Independence streams were outside the Missouri AQL range of 6.5 to 9.0 (fig. 11, 12), although a few continuous values for site 3 (table 2; fig. 1) were recorded above 9.0 standard units. Daily $\mathrm{pH}$ values ranged from 6.9 standard units at site 3 to 8.4 standard units at sites 4 and 7 .

Specific conductance of streamflow is a surrogate measurement for ionized constituent concentration and can be affected by several factors, including amount of precipitation and runoff, point-source contamination, and underlying soil and rock composition. The State of Missouri does not have a designated guideline or standard for specific conductance of stream waters. The duration curve of recorded daily specific conductance values is shown in figure 12 . The daily average values of specific conductance ranged from a minimum of 221 microsiemens per centimeter at $25^{\circ} \mathrm{C}(\mu \mathrm{S} / \mathrm{cm}$ at $25^{\circ} \mathrm{C}$; hereafter referred to as $\mu \mathrm{S} / \mathrm{cm}$ ) at site 3 (table 2; fig. 1) to a maximum of $3,680 \mu \mathrm{S} / \mathrm{cm}$ at site 7 (fig. 11). The range of recorded specific conductance daily average values was generally higher for the smaller streams in Independence (sites 1, 3, and 7) than for the larger stream sites on the Little Blue River and the East Fork of the Little Blue River (sites 2, 4, and 9).

For warm-water streams in the State of Missouri, the AQL standard for water temperature is $32.2{ }^{\circ} \mathrm{C}(90$ degrees Fahrenheit $\left[{ }^{\circ} \mathrm{F}\right]$; Missouri Department of Natural Resources, 2014b). Daily average values of water temperature ranged from $-0.2^{\circ} \mathrm{C}$ at site 7 (fig. 11 ) to $32.4^{\circ} \mathrm{C}$ at site 9 (table 2; fig. 1). The duration curve shown on figure 12 for daily average water temperatures recorded from the CWQMs in Independence streams indicates that the Missouri AQL was only exceeded less than 1 percent of the time. The continuous water-quality data, however, indicate more frequent exceedance, but only of short duration (less than 10 hours) at site 7 during the summer of WY 2006 and sites 3 and 4 during summer WY 2010.
Turbidity in water can have a variety of sources, such as fine sediment, suspended organic matter, plankton or other microscopic organisms, organic acids, and dyes (American Society of Testing Materials International, 2002). Turbidity was measured to determine the clarity of the water and to be used as an indicator of the stream ecological condition and health. The study area in Independence is covered by EPA level III ecoregion 40 guidelines (U.S. Environmental Protection Agency, 2000). The recommended guideline for turbidity is 15.5 nephelometric turbidity units (NTU). The 15.5-NTU guideline is considered a reference only and was used merely for comparison to the measured data to determine if the data were considered to be high. Daily average turbidity exceeded the U.S. Environmental Protection Agency (EPA) recommended guideline between 15 and 60 percent of the time (fig. 12). Most measured turbidity values that exceeded the recommended 15.5-NTU guideline for turbidity of stream water were recorded during periods of high flow. Both the maximum (1,054 NTU) and minimum (0.0 NTU) daily average turbidity values for sites with CWQMs installed during the study period were recorded at Lee's Summit Road (site 2; fig. 11). The maximum turbidity sensor range reported by the sensor manufacturer is 1,000 NTU; however, individual sensors used in this study recorded maximum values ranging from about 1,200 to 1,500 NTU that were considered valid, depending on the individual sensor. On occasion during this study, the maximum individual turbidity sensor values were exceeded so that daily average turbidity values may have been higher than reported on some days.

\section{Instantaneous Base-Flow Water Quality}

From June 2006 to September 2013, 175 base-flow waterquality samples were collected at 10 sites (sites 1 through 9 and 11; table 9, http://pubs.usgs.gov/ds/0915/downloads/ ds915_table09.xlsx). Base-flow samples were collected at five sites (sites 1, 5, 6, 7, and 9) beginning in June of 2006. Site 5 was discontinued in WY 2009, and site 6 was discontinued in WY 2008 when the gage was removed, but was reinstated as a sample site in WY 2010. Five other current (2014) sample sites began collection in WY 2008 (site 3), WY 2009 (site 4), WY 2010 (sites 2 and 8), and WY 2012 (site 11). Site 8 was subsequently discontinued in WY 2011. Most of the samples were split between the spring and early summer season (73 samples) and the winter season (71 samples), with the remainder (31 samples) collected during the fall transitional season. Streamflow, physical and chemical properties, TDS, sodium, chloride, nutrients, metals, cyanide, dissolved mercury, OMCs, pesticides in streambed sediment and surface water, FIB, and SSC data were collected. FIB results are discussed in the Fecal Indicator Bacteria, Microbial Source Tracking, and Suspended Sediment section later in this report. Results from individual base-flow samples are presented in appendix 1. 
Instantaneous measurements of physical and chemical properties taken at the time of base-flow sampling in Independence streams varied within the normal range for environmental waters (Hem, 1992; table 9). Dissolved oxygen varied from $3.1 \mathrm{mg} / \mathrm{L}$ to $17.2 \mathrm{mg} / \mathrm{L}$. The range of $\mathrm{pH}$ was narrow and varied from slightly acidic at 6.3 standard units to a slightly alkaline value of 8.4 standard units. Specific conductance values for all base-flow samples ranged between $319 \mu \mathrm{S} / \mathrm{cm}$ and $2,100 \mu \mathrm{S} / \mathrm{cm}$. Water samples taken during the warmer months of May to September typically had low specific conductance values that did not exceed $1,000 \mu \mathrm{S} / \mathrm{cm}$. Two sets of samples taken during the winter season had higher specific conductance values than most of the other samples. One set of samples collected on December 5, 2006, had a specific conductance range of between $873 \mu \mathrm{S} / \mathrm{cm}$ and $1,720 \mu \mathrm{S} / \mathrm{cm}$ and another set of base-flow samples taken on March 3, 2013, had a range of $438 \mu \mathrm{S} / \mathrm{cm}$ to $1,900 \mu \mathrm{S} / \mathrm{cm}$. All but one sample during the March 3, 2013, sampling had specific conductance values between $1,320 \mu \mathrm{S} / \mathrm{cm}$ and $1,900 \mu \mathrm{S} / \mathrm{cm}$. Water temperature for all base-flow samples ranged from $-0.1^{\circ} \mathrm{C}$ to $31.1^{\circ} \mathrm{C}$ and turbidity from 0.3 NTU to $300 \mathrm{NTU}$ (table 9).

\section{Instantaneous Stormflow Water Quality}

From June 2005 through September 2013, 205 stormflow water-quality samples were collected at 10 sites (sites 1 through 9 and 11; table 10, http://pubs.usgs.gov/ds/0915/ downloads/ds915_table10.xlsx). Sites 1, 5, 6, 7, and 9 were collected beginning in June of 2005. Site 5 was discontinued in WY 2009, and site 6 was discontinued in WY 2008 when the gage was removed but was reinstated as a sample site in WY 2010. Five other sample sites began collection later in the study, in WY 2008 (site 3), WY 2009 (site 2), WY 2010 (sites 4 and 8), and WY 2012 (site 11). During the summer months, 80 stormflow samples were collected, 66 during winter months, and 59 during the fall transitional season. Streamflow, physical and chemical properties, TDS, sodium, chloride, nutrients, total metals, cyanide, dissolved mercury, OMCs, pesticides in surface water, FIB, and SSC data were collected. FIB results are discussed in the Fecal Indicator Bacteria, Microbial Source Tracking, and Suspended Sediment section later in this report. Results from individual stormflow samples are presented in appendix 2 (http://pubs.usgs.gov/ds/0915/ downloads/ds915_Appendix02.xlsx).

Instantaneous measurements of physical and chemical properties in Independence streams taken at the time of stormflow sampling, either in situ or from the collected sample in the laboratory, varied within the normal range for environmental waters (Hem, 1992; table 10). Dissolved oxygen ranged from $5.9 \mathrm{mg} / \mathrm{L}$ to $15.7 \mathrm{mg} / \mathrm{L}$ (table 10 ). The $\mathrm{pH}$ ranged from near neutral at 6.6 standard units to slightly alkaline at 8.3 standard units. Specific conductance ranged from $101 \mu \mathrm{S} / \mathrm{cm}$ to $2,160 \mu \mathrm{S} / \mathrm{cm}$. Water temperatures that were either measured in the stream at the time of sampling or a calculated average from measured CWQM data for the time period during sampling ranged from $0.1{ }^{\circ} \mathrm{C}$ to $28.3{ }^{\circ} \mathrm{C}$ (table 10). Turbidity in stormflow samples ranged from 5 NTU to 4,840 NTU.

\section{Select Inorganic Constituents}

Total dissolved solids measured in base-flow samples ranged from $187 \mathrm{mg} / \mathrm{L}$ to $1,190 \mathrm{mg} / \mathrm{L}$ (table 9). The median TDS value for most sites was close to the median for all sites of $441 \mathrm{mg} / \mathrm{L}$, and ranged from $250 \mathrm{mg} / \mathrm{L}$ at site 4 (table 2; fig. 1) to $531 \mathrm{mg} / \mathrm{L}$ at site 7 . The Little Blue River sites (sites 2, 5, and 9) typically had lower median TDS values than the smaller Independence streams (sites 1, 3, 6, 7, 8, and 11), although site 4 had a lower median value than that of the main stem Little Blue River sites.

Minimum (61 mg/L) and maximum (1,200 mg/L) measured TDS values in stormflow were similar to values collected during base-flow conditions (table 10). The median TDS value for stormflow $(211 \mathrm{mg} / \mathrm{L}$; table 10) was less than that of base flow (441 mg/L; table 9), and the median TDS values for stormflow at each site (sites 1 through 9) were lower than base-flow values and ranged from $153 \mathrm{mg} / \mathrm{L}$ to $241 \mathrm{mg} / \mathrm{L}$ (table 10). The Little Blue River sites (sites 2, 5, and 9) had comparable values to those measured on the smaller streams in Independence (sites 1, 3, 4, 6, 7, and 8).

Daily average streamflow, estimated annual load, and estimated annual flow-weighted concentrations of select constituents measured at sites 1 through 9, along with the regression models used to calculate each value, are listed in table 11. The highest estimated annual load of TDS was 72,600 megagrams (Mg) at site 9 in WY 2010. The estimated annual load of TDS and annual average streamflow was highest at site 9 for all years from WY 2006 to 2013. The estimated annual flow-weighted concentration of TDS ranged from $134 \mathrm{mg} / \mathrm{L}$ at site 2 in WY 2013 to 1,123 mg/L at site 1 in WY 2006. Site 1 had the highest estimated annual flow-weighted concentration of TDS in all WYs except 2009, when it was highest at site 3 (table 11).

Chloride concentrations in base-flow samples ranged from $16.9 \mathrm{mg} / \mathrm{L}$ to $459 \mathrm{mg} / \mathrm{L}$ (table 9). Fifteen chloride concentrations measured in Independence streams at sites 1 through 9 and 11 during individual sampling events in December 2006, January 2010 and 2011, and March 2013 (appendix 1) were higher than the chronic standard for AQL of $230 \mathrm{mg} / \mathrm{L}$ previously established for Missouri streams. The recently updated (January 2014) Missouri AQL standard for chloride (Missouri Department of Natural Resources, 2014 b) is based on the hardness of the water sampled. The latest standard will not be used for this study because it was updated more recently than the study period and no hardness data were collected for any samples prior to November 2012. Site 3 also had measured chloride concentrations more than $230 \mathrm{mg} / \mathrm{L}$ during February 2009 and 2011, and March 2010. No measured chloride concentrations exceeded the Missouri acute standard for AQL of $860 \mathrm{mg} / \mathrm{L}$ (Missouri Department of Natural Resources, 2014b). 

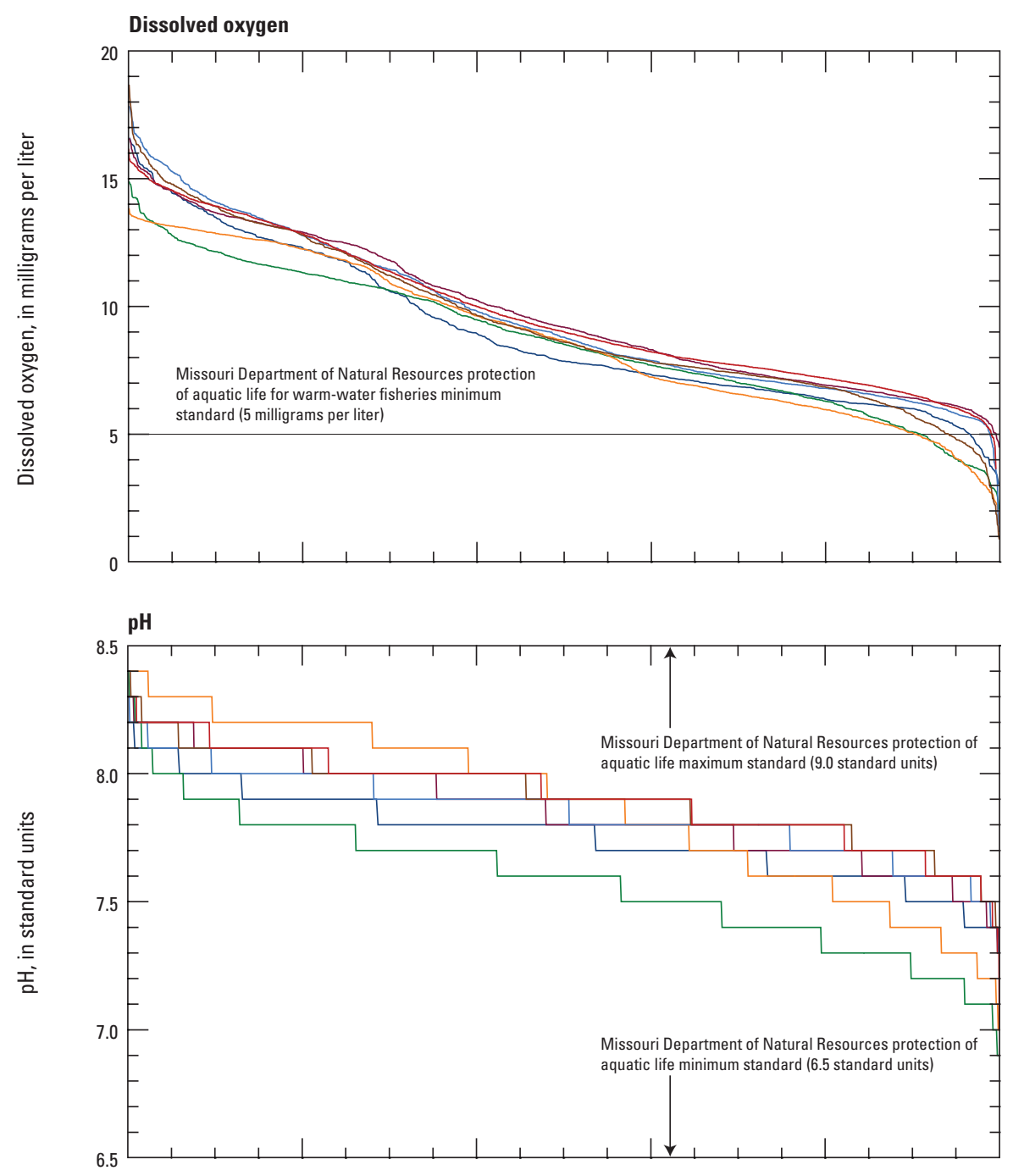

EXPLANATION

Site number and U.S. Geological Survey streamgage number-Table 2; fig. 1

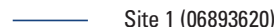
Site $2(06893820)$ Site $3(06893830)$ Site 4 (06893890) Site $5(06893910)$ Site 7 (06893970) Site 9 (06894000)

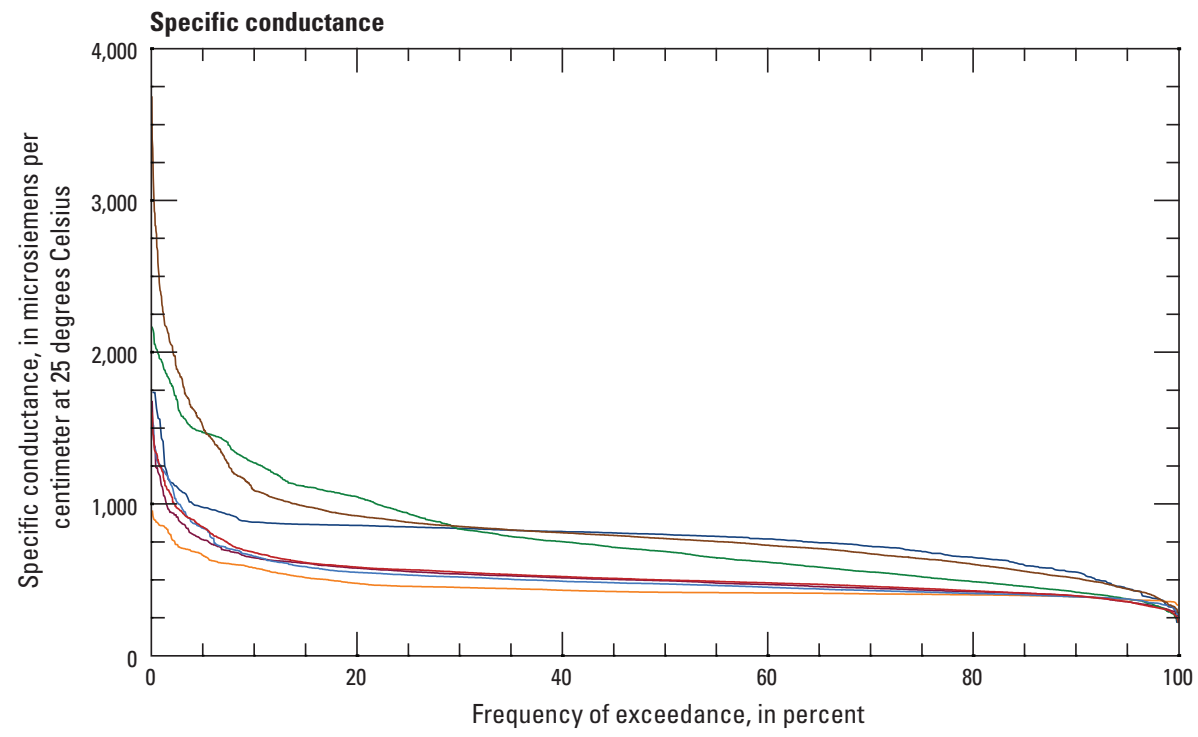

Figure 12. Frequency of exceedance of daily average dissolved oxygen, $\mathrm{pH}$, specific conductance, water temperature, and turbidity at sampling sites equipped with continuous water-quality monitors in Independence, Missouri. Period of record at individual sites varies. 

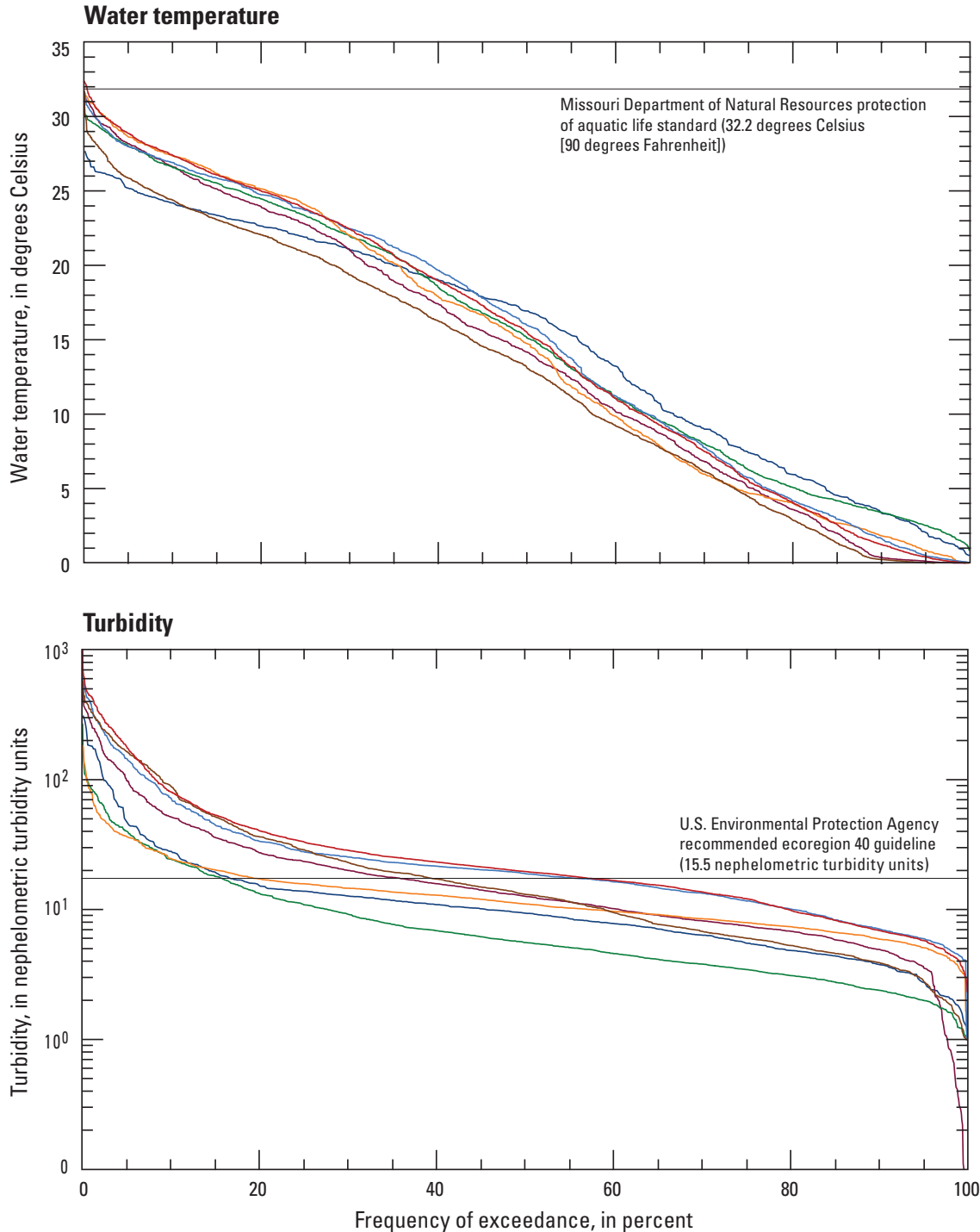

\section{EXPLANATION}

Site number and U.S. Geological Surve streamgage number-Table 2; fig. 1

Site 1 (06893620) Site 2 (06893820) Site $3(06893830)$ Site $4(06893890)$ Site $5(06893910)$ Site $7(06893970)$ Site $9(06894000)$

Figure 12. Frequency of exceedance of daily average dissolved oxygen, $\mathrm{pH}$, specific conductance, water temperature, and turbidity at sampling sites equipped with continuous water-quality monitors in Independence, Missouri. Period of record at individual sites varies. - Continued

Measured chloride concentrations in stormflow ranged from $3.4 \mathrm{mg} / \mathrm{L}$ to $508 \mathrm{mg} / \mathrm{L}$ (table 10 ). The highest concentration of chloride measured in stormflow samples occurred in February 2011 at site 3 (appendix 2). No measured chloride concentrations exceeded the Missouri acute AQL standard of $860 \mathrm{mg} / \mathrm{L}$ (Missouri Department of Natural Resources, 2014b). There were 11 measured chloride concentrations in stormflow that exceeded the Missouri chronic standard for $\mathrm{AQL}$ of $230 \mathrm{mg} / \mathrm{L}$ for chloride. Five of the highest chloride values were recorded at site 7 (appendix 2).

The estimated annual load of chloride was highest at downstream site 9 for all WYs from 2006 to 2013 (table 11). The highest estimated annual chloride load was $14,100 \mathrm{Mg}$ at site 9 in WY 2010. The estimated annual flow-weighted chloride concentrations were highest at site 7 for the first three years of record (WYs 2006 to 2008), but were highest at site 3 when the site was installed in WY 2009 to WY 2013. The highest estimated annual flow-weighted concentration for chloride was $152 \mathrm{mg} / \mathrm{L}$ in WY 2013 at site 3. Site 7 had the second highest annual flow-weighted chloride concentrations for all years after the installation of site 3 .

\section{Nutrients}

Concentrations of nutrients in base-flow samples, including total $\mathrm{N}$ and $\mathrm{P}$, are summarized in table 9. Site 11 (table 2; fig. 1) had the highest median concentrations for total $\mathrm{N}$ $(2.2 \mathrm{mg} / \mathrm{L})$ and $\mathrm{P}(0.152 \mathrm{mg} / \mathrm{L})$. All other sites ranged from 0.5 to $1.5 \mathrm{mg} / \mathrm{L}$ for total $\mathrm{N}$ and 0.045 to $0.131 \mathrm{mg} / \mathrm{L}$ for total $\mathrm{P}$. Median total organic $\mathrm{N}$ and dissolved nitrate account for 84 percent of the median total $\mathrm{N}$ concentration in all base-flow 
Table 11. Regression models for estimating annual loads, flow-weighted concentrations, and densities of selected sampled water-quality constituents.

$\left[n\right.$, number of samples; $R^{2}$, coefficient of determination; RMSE, root mean squared error; $\mathrm{ft}$ /s, cubic feet per second; ln, natural logarithm; L, instantaneous (daily) load; $\ln (\mathrm{Q})$, $\ln ($ streamflow) minus center of $\ln \left(\right.$ streamflow); $\ln \left(\mathrm{Q}^{2}\right)$, In of streamflow squared; T, decimal time minus center of decimal time; $\mathrm{T}^{2}$, decimal time squared; sin, sine; cos, cosine; --, no data; E. coli, Escherichia coli; mL, milliliters; for purposes of load calculation, recorded zero average daily streamflows were assigned a minimal value of $\left.0.01 \mathrm{ft}^{3} / \mathrm{s}\right]$

\begin{tabular}{|c|c|c|c|c|c|c|c|c|c|c|c|c|c|c|}
\hline \multirow{2}{*}{$\begin{array}{l}\text { Site number } \\
\text { (table 2; } \\
\text { fig. 1) }\end{array}$} & \multirow[b]{2}{*}{ Regression model } & \multirow[b]{2}{*}{$n$} & \multirow[b]{2}{*}{$R^{2}$} & \multirow[b]{2}{*}{ RMSE $^{1}$} & \multirow{2}{*}{$\begin{array}{c}\text { Sample average } \\
\text { daily } \\
\text { streamflow } \\
\left(\mathrm{ft}^{3} / \mathbf{s}\right)\end{array}$} & \multirow{2}{*}{$\begin{array}{c}\text { Study period of } \\
\text { record average } \\
\text { daily streamflow } \\
\left(\mathrm{ft}^{3} / \mathrm{s}\right)\end{array}$} & \multicolumn{8}{|c|}{ Average annual ${ }^{2}$ streamflow $\left(\mathrm{ft}^{3} / \mathrm{s}\right)$} \\
\hline & & & & & & & 2006 & 2007 & 2008 & 2009 & 2010 & 2011 & 2012 & 2013 \\
\hline \multicolumn{15}{|c|}{ Total dissolved solids } \\
\hline 1 & $\ln (\mathrm{L})=0.773 \ln (\mathrm{Q})-0.016 \ln \left(\mathrm{Q}^{2}\right)-0.019 \mathrm{~T}-0.16 \mathrm{~T}^{2}+0.166 \sin (2 \pi \mathrm{T})+0.139 \cos (2 \pi \mathrm{T})+9.36$ & 55 & 0.978 & 0.278 & 77.0 & 6.33 & 2.16 & 6.32 & 9.56 & 9.19 & 9.73 & 5.26 & 3.00 & 4.80 \\
\hline 2 & $\ln (\mathrm{L})=0.917 \ln (\mathrm{Q})+0.266 \sin (2 \pi \mathrm{T})+0.200 \cos (2 \pi \mathrm{T})+3.83$ & 28 & 0.977 & 0.240 & 198 & 88.7 & -- & -- & -- & -- & 170 & 45.4 & 44.5 & 96.8 \\
\hline 3 & $\ln (\mathrm{L})=0.939 \ln (\mathrm{Q})-0.012 \ln \left(\mathrm{Q}^{2}\right)+0.421 \sin (2 \pi \mathrm{T})+0.242 \cos (2 \pi \mathrm{T})+1.69$ & 34 & 0.992 & 0.245 & 62.2 & 5.53 & -- & -- & -- & 6.78 & 7.99 & 3.93 & 3.82 & 5.15 \\
\hline${ }^{5} 4$ & $\ln (\mathrm{L})=0.948 \ln (\mathrm{Q})+0.263$ & 26 & 0.993 & 0.179 & 22.8 & 27.2 & -- & -- & -- & -- & ${ }^{6} 57.9$ & 15.7 & 10.2 & 29.1 \\
\hline 5 & $\ln (\mathrm{L})=0.882 \ln (\mathrm{Q})+0.152 \sin (2 \pi \mathrm{T})+0.242 \cos (2 \pi \mathrm{T})+4.61$ & 26 & 0.979 & 0.222 & 533 & 130 & 28.6 & 146 & 184 & 151 & -- & -- & -- & -- \\
\hline 6 & $\ln (\mathrm{L})=0.796 \ln (\mathrm{Q})-0.018 \ln \left(\mathrm{Q}^{2}\right)+0.203 \sin (2 \pi \mathrm{T})+0.388 \cos (2 \pi \mathrm{T})+2.13$ & 38 & 0.972 & 0.358 & 97.6 & 4.44 & 1.48 & 5.14 & 6.39 & -- & -- & -- & -- & -- \\
\hline${ }^{5} 7$ & $\ln (\mathrm{L})=0.805 \ln (\mathrm{Q})-0.020 \ln \left(\mathrm{Q}^{2}\right)-0.052 \mathrm{~T}+0.252 \sin (2 \pi \mathrm{T})+0.377 \cos (2 \pi \mathrm{T})+2.32$ & 53 & 0.976 & 0.342 & 81.0 & 8.14 & 3.22 & 10.6 & 10.5 & 9.44 & 12.9 & 4.95 & -- & 5.83 \\
\hline 9 & $\ln (\mathrm{L})=0.907 \ln (\mathrm{Q})-0.024 \ln \left(\mathrm{Q}^{2}\right)+0.169 \sin (2 \pi \mathrm{T})+0.150 \cos (2 \pi \mathrm{T})+4.82^{5}$ & 54 & 0.980 & 0.227 & 541 & 178 & 41.3 & 202 & 259 & 226 & 314 & 105 & 81.2 & 163 \\
\hline \multicolumn{15}{|c|}{ Chloride } \\
\hline 1 & $\ln (\mathrm{L})=0.738 \ln (\mathrm{Q})-0.031 \ln \left(\mathrm{Q}^{2}\right)+0.405 \sin (2 \pi \mathrm{T})+0.460 \cos (2 \pi \mathrm{T})+0.434$ & 71 & 0.930 & 0.469 & 61.6 & 6.33 & 2.16 & 6.32 & 9.56 & 9.19 & 9.73 & 5.26 & 3.00 & 4.80 \\
\hline$s_{2}$ & $\ln (\mathrm{L})=1.02 \ln (\mathrm{Q})-0.059 \ln \left(\mathrm{Q}^{2}\right)+0.075 \mathrm{~T}+0.129 \mathrm{~T}^{2}+0.524 \sin (2 \pi \mathrm{T})+0.332 \cos (2 \pi \mathrm{T})+1.93$ & 33 & 0.934 & 0.455 & 176 & 88.7 & -- & -- & -- & -- & 170 & 45.4 & 44.5 & 96.8 \\
\hline 3 & $\ln (\mathrm{L})=0.942 \ln (\mathrm{Q})-0.017 \ln \left(\mathrm{Q}^{2}\right)+0.797 \sin (2 \pi \mathrm{T})+0.311 \cos (2 \pi \mathrm{T})+0.386$ & 45 & 0.972 & 0.433 & 47.5 & 5.53 & -- & -- & -- & 6.78 & 7.99 & 3.93 & 3.82 & 5.15 \\
\hline${ }^{5} 4$ & $\ln (\mathrm{L})=0.972 \ln (\mathrm{Q})+0.001 \ln \left(\mathrm{Q}^{2}\right)+0.044 \mathrm{~T}+0.077 \mathrm{~T}^{2}+0.114 \sin (2 \pi \mathrm{T})+0.044 \cos (2 \pi \mathrm{T})-1.37$ & 34 & 0.987 & 0.263 & 28.3 & 27.2 & -- & -- & -- & -- & ${ }^{6} 57.9$ & 15.7 & 10.2 & 29.1 \\
\hline 5 & $\ln (\mathrm{L})=0.841 \ln (\mathrm{Q})+0.356 \sin (2 \pi \mathrm{T})+0.522 \cos (2 \pi \mathrm{T})+2.855$ & 27 & 0.927 & 0.430 & 504 & 130 & 28.6 & 146 & 184 & 151 & -- & -- & -- & -- \\
\hline${ }^{5} 6$ & $\ln (\mathrm{L})=0.735 \ln (\mathrm{Q})-0.025 \ln \left(\mathrm{Q}^{2}\right)+0.555 \sin (2 \pi \mathrm{T})+0.502 \cos (2 \pi \mathrm{T})+0.071$ & 39 & 0.916 & 0.625 & 90.8 & 4.44 & 1.48 & 5.14 & 6.39 & -- & -- & -- & -- & -- \\
\hline 7 & $\ln (\mathrm{L})=0.763 \ln (\mathrm{Q})-0.028 \ln \left(\mathrm{Q}^{2}\right)+0.449 \sin (2 \pi \mathrm{T})+0.742 \cos (2 \pi \mathrm{T})+0.256$ & 60 & 0.924 & 0.600 & 74.1 & 8.14 & 3.22 & 10.6 & 10.5 & 9.44 & 12.9 & 4.95 & -- & 5.83 \\
\hline${ }^{59}$ & $\ln (\mathrm{L})=0.875 \ln (\mathrm{Q})-0.046 \ln \left(\mathrm{Q}^{2}\right)+0.396 \sin (2 \pi \mathrm{T})+0.292 \cos (2 \pi \mathrm{T})+2.94$ & 61 & 0.915 & 0.480 & 553 & 178 & 41.3 & 202 & 259 & 226 & 314 & 105 & 81.2 & 163 \\
\hline \multicolumn{15}{|c|}{ Ammonia } \\
\hline 1 & $\ln (\mathrm{L})=1.15 \ln (\mathrm{Q})+0.050 \ln \left(\mathrm{Q}^{2}\right)-0.033 \mathrm{~T}+0.434 \mathrm{~T}^{2}+0.762 \sin (2 \pi \mathrm{T})-0.321 \cos (2 \pi \mathrm{T})+9.36$ & 68 & 0.924 & 0.799 & 79.8 & 6.33 & 2.16 & 6.32 & 9.56 & 9.19 & 9.73 & 5.26 & 3.00 & 4.80 \\
\hline 72 & $\ln (\mathrm{L})=1.10 \ln (\mathrm{Q})-0.173 \ln \left(\mathrm{Q}^{2}\right)+0.642 \mathrm{~T}-5.01$ & 28 & 0.781 & 0.983 & 198 & 88.7 & -- & -- & -- & -- & 170 & 45.4 & 44.5 & 96.8 \\
\hline${ }^{73}$ & $\ln (\mathrm{L})=1.03 \ln (\mathrm{Q})+0.283 \mathrm{~T}-7.98^{7}$ & 34 & 0.878 & 1.11 & 62.2 & 5.53 & -- & -- & -- & 6.78 & 7.99 & 3.93 & 3.82 & 5.15 \\
\hline 4 & $\ln (\mathrm{L})=0.886 \ln (\mathrm{Q})-7.97$ & 27 & 0.888 & 0.722 & 22.7 & 27.2 & -- & -- & -- & -- & ${ }^{6} 57.9$ & 15.7 & 10.2 & 29.1 \\
\hline 5 & $\ln (\mathrm{L})=1.03 \ln (\mathrm{Q})-0.201 \mathrm{~T}+0.696 \sin (2 \pi \mathrm{T})+0.301 \cos (2 \pi \mathrm{T})-3.99$ & 27 & 0.884 & 0.732 & 539 & 130 & 28.6 & 146 & 184 & 151 & -- & -- & -- & -- \\
\hline${ }^{7} 6$ & $\ln (\mathrm{L})=1.06 \ln (\mathrm{Q})+0.727 \sin (2 \pi \mathrm{T})+0.107 \cos (2 \pi \mathrm{T})-6.42$ & 38 & 0.880 & 1.05 & 97.6 & 4.44 & 1.48 & 5.14 & 6.39 & -- & -- & -- & -- & -- \\
\hline${ }^{77}$ & $\ln (\mathrm{L})=1.14 \ln (\mathrm{Q})+0.646 \sin (2 \pi \mathrm{T})+0.211 \cos (2 \pi \mathrm{T})-8.02$ & 53 & 0.835 & 1.34 & 81.0 & 8.14 & 3.22 & 10.6 & 10.5 & 9.44 & 12.9 & 4.95 & -- & 5.83 \\
\hline${ }^{7} 9$ & $\ln (\mathrm{L})=1.26 \ln (\mathrm{Q})+0.033 \ln \left(\mathrm{Q}^{2}\right)-0.098 \mathrm{~T}+0.076 \mathrm{~T}^{2}+0.497 \sin (2 \pi \mathrm{T})+0.039 \cos (2 \pi \mathrm{T})-5.02$ & 55 & 0.856 & 0.981 & 555 & 178 & 41.3 & 202 & 259 & 226 & 314 & 105 & 81.2 & 163 \\
\hline
\end{tabular}


Table 11. Regression models for estimating annual loads, flow-weighted concentrations, and densities of selected sampled water-quality constituents.-Continued

[ $n$, number of samples; $R^{2}$, coefficient of determination; RMSE, root mean squared error; $\mathrm{ft} / \mathrm{s}$, cubic feet per second; $\ln$, natural logarithm; L, instantaneous (daily) load; $\ln (\mathrm{Q})$, $\ln ($ streamflow) minus center of $\ln \left(\right.$ streamflow); $\ln \left(\mathrm{Q}^{2}\right)$, ln of streamflow squared; T, decimal time minus center of decimal time; $\mathrm{T}^{2}$, decimal time squared; sin, sine; cos, cosine; --, no data; E. coli, Escherichia coli; $\mathrm{mL}$, milliliters; for purposes of load calculation, recorded zero average daily streamflows were assigned a minimal value of $0.01 \mathrm{ft}^{3} / \mathrm{s}$ ]

\begin{tabular}{|c|c|c|c|c|c|c|c|c|c|c|c|c|c|c|}
\hline \multirow{2}{*}{$\begin{array}{l}\text { Site number } \\
\text { (table 2; } \\
\text { fig. 1) }\end{array}$} & \multirow[b]{2}{*}{ Regression model } & \multirow[b]{2}{*}{$n$} & \multirow[b]{2}{*}{$R^{2}$} & \multirow[b]{2}{*}{ RMSE' $^{1}$} & \multirow{2}{*}{$\begin{array}{c}\text { Sample average } \\
\text { daily } \\
\text { streamflow } \\
\left(\mathbf{f t}^{3} / \mathbf{s}\right)\end{array}$} & \multirow{2}{*}{$\begin{array}{c}\text { Study period of } \\
\text { record average } \\
\text { daily streamflow } \\
\left(\mathrm{ft}^{3} / \mathrm{s}\right)\end{array}$} & \multicolumn{8}{|c|}{ Average annual ${ }^{2}$ streamflow $\left(\mathrm{ft}^{3} / \mathrm{s}\right)$} \\
\hline & & & & & & & 2006 & 2007 & 2008 & 2009 & 2010 & 2011 & 2012 & 2013 \\
\hline \multicolumn{15}{|c|}{ Nitrate plus nitrite } \\
\hline 1 & $\ln (\mathrm{L})=0.853 \ln (\mathrm{Q})+0.22 \ln \left(\mathrm{Q}^{2}\right)-0.023 \sin (2 \pi \mathrm{T})-0.178 \cos (2 \pi \mathrm{T})-3.93$ & 68 & 0.978 & 0.295 & 79.8 & 6.33 & 2.16 & 6.32 & 9.56 & 9.19 & 9.73 & 5.26 & 3.00 & 4.80 \\
\hline 2 & $\ln (\mathrm{L})=1.28 \ln (\mathrm{Q})-0.063 \ln \left(\mathrm{Q}^{2}\right)+0.256 \mathrm{~T}-2.69$ & 28 & 0.918 & 0.631 & 198 & 88.7 & -- & -- & -- & -- & 170 & 45.4 & 44.5 & 96.8 \\
\hline 3 & $\ln (\mathrm{L})=0.998 \ln (\mathrm{Q})-6.34$ & 34 & 0.917 & 0.863 & 62.2 & 5.53 & -- & -- & -- & 6.78 & 7.99 & 3.93 & 3.82 & 5.15 \\
\hline${ }^{84}$ & $\ln (\mathrm{L})=1.05 \ln (\mathrm{Q})-6.92$ & 27 & 0.865 & 0.958 & 22.7 & 27.2 & -- & -- & -- & -- & ${ }^{6} 57.9$ & 15.7 & 10.2 & 29.1 \\
\hline 5 & $\ln (\mathrm{L})=1.24 \ln (\mathrm{Q})-0.135 \mathrm{~T}+0.222 \sin (2 \pi \mathrm{T})+0.141 \cos (2 \pi \mathrm{T})-2.17$ & 27 & 0.955 & 0.469 & 539 & 130 & 28.6 & 146 & 184 & 151 & -- & -- & -- & -- \\
\hline 6 & $\ln (\mathrm{L})=0.999 \ln (\mathrm{Q})-4.10$ & 38 & 0.968 & 0.453 & 97.6 & 4.44 & 1.48 & 5.14 & 6.39 & -- & -- & -- & -- & -- \\
\hline${ }^{87}$ & $\ln (\mathrm{L})=1.01 \ln (\mathrm{Q})-4.74$ & 53 & 0.947 & 0.631 & 81.0 & 8.14 & 3.22 & 10.6 & 10.5 & 9.44 & 12.9 & 4.95 & -- & 5.83 \\
\hline 9 & $\ln (\mathrm{L})=1.20 \ln (\mathrm{Q})-1.97$ & 55 & 0.922 & 0.593 & 555 & 178 & 41.3 & 202 & 259 & 226 & 314 & 105 & 81.2 & 163 \\
\hline \multicolumn{15}{|c|}{ Organic nitrogen } \\
\hline 1 & $\ln (\mathrm{L})=1.50 \ln (\mathrm{Q})-0.041 \ln \left(\mathrm{Q}^{2}\right)-0.039 \mathrm{~T}+0.019 \mathrm{~T}^{2}+0.122 \sin (2 \pi \mathrm{T})-0.092 \cos (2 \pi \mathrm{T})-3.93$ & 68 & 0.988 & 0.399 & 79.8 & 6.33 & 2.16 & 6.32 & 9.56 & 9.19 & 9.73 & 5.26 & 3.00 & 4.80 \\
\hline 2 & $\ln (\mathrm{L})=1.47 \ln (\mathrm{Q})+0.111 \mathrm{~T}-0.302 \sin (2 \pi \mathrm{T})-0.119 \cos (2 \pi \mathrm{T})-2.05$ & 28 & 0.983 & 0.331 & 198 & 88.7 & -- & -- & -- & -- & 170 & 45.4 & 44.5 & 96.8 \\
\hline 3 & $\ln (\mathrm{L})=1.14 \ln (\mathrm{Q})+0.019 \ln \left(\mathrm{Q}^{2}\right)+0.057 \mathrm{~T}-5.13$ & 34 & 0.995 & 0.242 & 62.2 & 5.53 & -- & -- & -- & 6.78 & 7.99 & 3.93 & 3.82 & 5.15 \\
\hline 54 & $\ln (\mathrm{L})=1.10 \ln (\mathrm{Q})-0.368 \sin (2 \pi \mathrm{T})-0.119 \cos (2 \pi \mathrm{T})-6.08$ & 27 & 0.965 & 0.484 & 22.7 & 27.2 & -- & -- & -- & -- & ${ }^{6} 57.9$ & 15.7 & 10.2 & 29.1 \\
\hline 5 & $\ln (\mathrm{L})=1.43 \ln (\mathrm{Q})+0.048 \ln \left(\mathrm{Q}^{2}\right)-1.26$ & 27 & 0.976 & 0.369 & 539 & 130 & 28.6 & 146 & 184 & 151 & -- & -- & -- & -- \\
\hline 6 & $\ln (\mathrm{L})=1.35 \ln (\mathrm{Q})+0.051 \ln \left(\mathrm{Q}^{2}\right)-0.133 \mathrm{~T}-3.97$ & 38 & 0.985 & 0.442 & 97.6 & 4.44 & 1.48 & 5.14 & 6.39 & -- & -- & -- & -- & -- \\
\hline 7 & $\ln (\mathrm{L})=1.43 \ln (\mathrm{Q})+0.054 \ln \left(\mathrm{Q}^{2}\right)-4.84$ & 53 & 0.986 & 0.439 & 81.0 & 8.14 & 3.22 & 10.6 & 10.5 & 9.44 & 12.9 & 4.95 & -- & 5.83 \\
\hline 9 & $\ln (\mathrm{L})=1.46 \ln (\mathrm{Q})+0.055 \ln \left(\mathrm{Q}^{2}\right)-0.095 \sin (2 \pi \mathrm{T})-0.171 \cos (2 \pi \mathrm{T})-1.17$ & 55 & 0.981 & 0.361 & 555 & 178 & 41.3 & 202 & 259 & 226 & 314 & 105 & 81.2 & 163 \\
\hline \multicolumn{15}{|c|}{ Total phosphorous } \\
\hline 1 & $\ln (\mathrm{L})=1.41 \ln (\mathrm{Q})+0.061 \ln \left(\mathrm{Q}^{2}\right)-0.033 \mathrm{~T}+0.171 \mathrm{~T}^{2}-0.112 \sin (2 \pi \mathrm{T})-0.174 \cos (2 \pi \mathrm{T})-4.92$ & 68 & 0.986 & 0.408 & 79.8 & 6.33 & 2.16 & 6.32 & 9.56 & 9.19 & 9.73 & 5.26 & 3.00 & 4.80 \\
\hline 2 & $\ln (\mathrm{L})=1.74 \ln (\mathrm{Q})+0.269 \mathrm{~T}-0.684 \sin (2 \pi \mathrm{T})-0.164 \cos (2 \pi \mathrm{T})-3.48$ & 28 & 0.965 & 0.560 & 198 & 88.7 & -- & -- & -- & -- & 170 & 45.4 & 44.5 & 96.8 \\
\hline 3 & $\ln (\mathrm{L})=1.22 \ln (\mathrm{Q})+0.046 \ln \left(\mathrm{Q}^{2}\right)-0.044 \mathrm{~T}+0.070 \mathrm{~T}^{2}-0.184 \sin (2 \pi \mathrm{T})-0.105 \cos (2 \pi \mathrm{T})-4.92$ & 34 & 0.995 & 0.313 & 62.2 & 5.53 & -- & -- & -- & 6.78 & 7.99 & 3.93 & 3.82 & 5.15 \\
\hline 4 & $\ln (\mathrm{L})=1.18 \ln (\mathrm{Q})+0.018 \ln \left(\mathrm{Q}^{2}\right)-0.434 \mathrm{~T}-0.420 \mathrm{~T}^{2}-1.02 \sin (2 \pi \mathrm{T})+0.039 \cos (2 \pi \mathrm{T})-7.44$ & 27 & 0.881 & 0.907 & 22.7 & 27.2 & -- & -- & -- & -- & ${ }^{6} 57.9$ & 15.7 & 10.2 & 29.1 \\
\hline 5 & $\ln (\mathrm{L})=1.56 \mathrm{n}(\mathrm{Q})+0.059 \ln \left(\mathrm{Q}^{2}\right)-2.60$ & 27 & 0.957 & 0.541 & 539 & 130 & 28.6 & 146 & 184 & 151 & -- & -- & -- & -- \\
\hline 6 & $\ln (\mathrm{L})=1.41 \ln (\mathrm{Q})-0.057 \ln \left(\mathrm{Q}^{2}\right)-0.128 \mathrm{~T}-5.04$ & 38 & 0.980 & 0.534 & 97.6 & 4.44 & 1.48 & 5.14 & 6.39 & -- & -- & -- & -- & -- \\
\hline 7 & $\ln (\mathrm{L})=1.46 \ln (\mathrm{Q})+0.051 \ln \left(\mathrm{Q}^{2}\right)-0.197 \sin (2 \pi \mathrm{T})-0.278 \cos (2 \pi \mathrm{T})-5.44$ & 53 & 0.974 & 0.634 & 81.0 & 8.14 & 3.22 & 10.6 & 10.5 & 9.44 & 12.9 & 4.95 & -- & 5.83 \\
\hline 9 & $\ln (\mathrm{L})=1.68 \ln (\mathrm{Q})+0.071 \ln \left(\mathrm{Q}^{2}\right)-0.355 \sin (2 \pi \mathrm{T})-0.289 \cos (2 \pi \mathrm{T})-2.54$ & 55 & 0.967 & 0.549 & 555 & 178 & 41.3 & 202 & 259 & 226 & 314 & 105 & 81.2 & 163 \\
\hline
\end{tabular}


$\left[n\right.$, number of samples; $R^{2}$, coefficient of determination; RMSE, root mean squared error; $\mathrm{ft} / \mathrm{s}$, cubic feet per second; ln, natural logarithm; L, instantaneous (daily) load; ln(Q), ln(streamflow) minus center of $\ln \left(\right.$ streamflow); $\ln \left(\mathrm{Q}^{2}\right), \ln$ of streamflow squared; $\mathrm{T}$, decimal time minus center of decimal time; $\mathrm{T}^{2}$, decimal time squared; sin, sine; cos, cosine; --, no data; E. coli, Escherichia coli; mL, milliliters; for purposes of load calculation, recorded zero average daily streamflows were assigned a minimal value of $\left.0.01 \mathrm{ft}^{3} / \mathrm{s}\right]$

\begin{tabular}{|c|c|c|c|c|c|c|c|c|c|c|c|c|c|c|}
\hline \multirow{2}{*}{$\begin{array}{l}\text { Site number } \\
\text { (table 2; } \\
\text { fig. 1) }\end{array}$} & \multirow[b]{2}{*}{ Regression model } & \multirow{3}{*}{$n$} & \multirow[b]{2}{*}{$R^{2}$} & \multirow[b]{2}{*}{ RMSE $^{1}$} & \multirow{2}{*}{$\begin{array}{c}\text { Sample average } \\
\text { daily } \\
\text { streamflow } \\
\left(\mathrm{ft}^{3} / \mathrm{s}\right)\end{array}$} & \multirow{2}{*}{$\begin{array}{c}\text { Study period of } \\
\text { record average } \\
\text { daily streamflow } \\
\left(\mathrm{ft}^{3} / \mathrm{s}\right)\end{array}$} & \multicolumn{8}{|c|}{ Average annual' streamflow (ft $3 / \mathbf{s})$} \\
\hline & & & & & & & 2006 & 2007 & 2008 & 2009 & 2010 & 2011 & 2012 & 2013 \\
\hline \multicolumn{14}{|c|}{ Total nitrogen } & \\
\hline 1 & $\ln (\mathrm{L})=1.18 \ln (\mathrm{Q})-0.057 \ln \left(\mathrm{Q}^{2}\right)-0.035 \mathrm{~T}+0.066 \sin (2 \pi \mathrm{T})-0.150 \cos (2 \pi \mathrm{T})-2.91$ & 68 & 0.989 & 0.291 & 79.8 & 6.33 & 2.16 & 6.32 & 9.56 & 9.19 & 9.73 & 5.26 & 3.00 & 4.80 \\
\hline 2 & $\ln (\mathrm{L})=1.40 \ln (\mathrm{Q})+0.176 \mathrm{~T}-1.61$ & 28 & 0.979 & 0.332 & 198 & 88.7 & -- & -- & -- & -- & 170 & 45.4 & 44.5 & 96.8 \\
\hline 3 & $\ln (\mathrm{L})=1.12 \ln (\mathrm{Q})+0.012 \ln \left(\mathrm{Q}^{2}\right)+0.083 \mathrm{~T}-4.71$ & 34 & 0.995 & 0.227 & 62.2 & 5.53 & -- & -- & -- & 6.78 & 7.99 & 3.93 & 3.82 & 5.15 \\
\hline 4 & $\ln (\mathrm{L})=1.09 \ln (\mathrm{Q})-0.367 \sin (2 \pi \mathrm{T})-0.005 \cos (2 \pi \mathrm{T})-5.57$ & 27 & 0.957 & 0.528 & 22.7 & 27.2 & -- & -- & -- & -- & ${ }^{6} 57.9$ & 15.7 & 10.2 & 29.1 \\
\hline${ }^{5} 5$ & $\ln (\mathrm{L})=1.34 \ln (\mathrm{Q})-0.722$ & 27 & 0.974 & 0.357 & 539 & 130 & 28.6 & 146 & 184 & 151 & -- & -- & -- & -- \\
\hline 6 & $\ln (\mathrm{L})=1.22 \ln (\mathrm{Q})+0.026 \ln \left(\mathrm{Q}^{2}\right)-0.075 \mathrm{~T}-3.09$ & 38 & 0.986 & 0.382 & 97.6 & 4.44 & 1.48 & 5.14 & 6.39 & -- & -- & -- & -- & -- \\
\hline 7 & $\ln (\mathrm{L})=1.29 \ln (\mathrm{Q})+0.028 \ln \left(\mathrm{Q}^{2}\right)+0.088 \sin (2 \pi \mathrm{T})-0.173 \cos (2 \pi \mathrm{T})-3.65$ & 53 & 0.984 & 0.429 & 81.0 & 8.14 & 3.22 & 10.6 & 10.5 & 9.44 & 12.9 & 4.95 & -- & 5.83 \\
\hline 9 & $\ln (\mathrm{L})=1.38 \ln (\mathrm{Q})+0.043 \ln \left(\mathrm{Q}^{2}\right)-0.708$ & 55 & 0.975 & 0.38 & 555 & 178 & 41.3 & 202 & 259 & 226 & 314 & 105 & 81.2 & 163 \\
\hline \multicolumn{15}{|c|}{ E. coli (colonies $/ 100 \mathrm{~mL})^{9}$} \\
\hline 1 & $\ln (\mathrm{L})=1.89 \ln (\mathrm{Q})-0.182 \sin (2 \pi \mathrm{T})-0.898 \cos (2 \pi \mathrm{T})+13.8$ & 48 & 0.964 & 0.905 & 81.1 & 6.33 & 2.16 & 6.32 & 9.56 & 9.19 & 9.73 & 5.26 & 3.00 & 4.80 \\
\hline 2 & $\ln (\mathrm{L})=2.52 \ln (\mathrm{Q})-1.66 \sin (2 \pi \mathrm{T})-0.263 \cos (2 \pi \mathrm{T})+14.1$ & 25 & 0.907 & 1.31 & 188 & 88.7 & -- & -- & -- & -- & 170 & 45.4 & 44.5 & 96.8 \\
\hline 3 & $\ln (\mathrm{L})=1.54 \ln (\mathrm{Q})+0.072 \ln \left(\mathrm{Q}^{2}\right)+0.476 \mathrm{~T}+0.070 \mathrm{~T}^{2}-1.19 \sin (2 \pi \mathrm{T})-1.16 \cos (2 \pi \mathrm{T})+8.70$ & 30 & 0.897 & 1.74 & 55.5 & 5.53 & -- & -- & -- & 6.78 & 7.99 & 3.93 & 3.82 & 5.15 \\
\hline 4 & $\ln (\mathrm{L})=0.872 \ln (\mathrm{Q})-0.125 \ln \left(\mathrm{Q}^{2}\right)-2.11 \sin (2 \pi \mathrm{T})-0.655 \cos (2 \pi \mathrm{T})+10.6$ & 24 & 0.673 & 1.55 & 21.9 & 27.2 & -- & -- & -- & -- & ${ }^{6} 57.9$ & 15.7 & 10.2 & 29.1 \\
\hline 5 & $\ln (\mathrm{L})=2.25 \ln (\mathrm{Q})-0.1 \mathrm{q} 5 \ln \left(\mathrm{Q}^{2}\right)-0.733 \sin (2 \pi \mathrm{T})-0.326 \cos (2 \pi \mathrm{T})+15.9$ & 25 & 0.936 & 1.01 & 547 & 130 & 28.6 & 146 & 184 & 151 & -- & -- & -- & -- \\
\hline 6 & $\ln (\mathrm{L})=1.73 \ln (\mathrm{Q})-0.105 \mathrm{~T}-0.773 \sin (2 \pi \mathrm{T})-1.06 \cos (2 \pi \mathrm{T})+13.3$ & 35 & 0.964 & 0.930 & 91.9 & 4.44 & 1.48 & 5.14 & 6.39 & -- & -- & -- & -- & -- \\
\hline 7 & $\ln (\mathrm{L})=1.82 \ln (\mathrm{Q})-0.616 \sin (2 \pi \mathrm{T})-1.02 \cos (2 \pi \mathrm{T})+13.1$ & 45 & 0.958 & 1.00 & 89.9 & 8.14 & 3.22 & 10.6 & 10.5 & 9.44 & 12.9 & 4.95 & -- & 5.83 \\
\hline 9 & $\ln (\mathrm{L})=2.35 \ln (\mathrm{Q})-1.16 \sin (2 \pi \mathrm{T})-0.757 \cos (2 \pi \mathrm{T})+15.1$ & 50 & 0.918 & 1.26 & 618 & 178 & 41.3 & 202 & 259 & 226 & 314 & 105 & 81.2 & 163 \\
\hline \multicolumn{15}{|c|}{ Suspended sediment } \\
\hline 1 & $\ln (\mathrm{L})=1.62 \mathrm{n}(\mathrm{Q})+0.054 \ln \left(\mathrm{Q}^{2}\right)-0.072 \mathrm{~T}+1.36$ & 58 & 0.961 & 0.742 & 71.3 & 6.33 & 2.16 & 6.32 & 9.56 & 9.19 & 9.73 & 5.26 & 3.00 & 4.80 \\
\hline 2 & $\ln (\mathrm{L})=2.04 \ln (\mathrm{Q})-0.604 \sin (2 \pi \mathrm{T})-0.123 \cos (2 \pi \mathrm{T})+2.65$ & 28 & 0.948 & 0.807 & 198 & 88.7 & -- & -- & -- & -- & 170 & 45.4 & 44.5 & 96.8 \\
\hline 3 & $\ln (\mathrm{L})=1.24 \ln (\mathrm{Q})-0.798$ & 33 & 0.945 & 0.861 & 64.1 & 5.53 & -- & -- & -- & 6.78 & 7.99 & 3.93 & 3.82 & 5.15 \\
\hline 4 & $\ln (\mathrm{L})=1.25 \ln (\mathrm{Q})-0.0003\left(\mathrm{Q}^{2}\right)+0.480 \mathrm{~T}-0.582 \mathrm{~T}^{2}-0.972 \sin (2 \pi \mathrm{T})+0.0358 \cos (2 \pi \mathrm{T})-1.34$ & 26 & 0.811 & 1.28 & 22.8 & 27.2 & -- & -- & -- & -- & ${ }^{6} 57.9$ & 15.7 & 10.2 & 29.1 \\
\hline 5 & $\ln (\mathrm{L})=1.77 \ln (\mathrm{Q})+0.078 \ln \left(\mathrm{Q}^{2}\right)-0.150 \mathrm{~T}+3.81$ & 26 & 0.965 & 0.569 & 533 & 130 & 28.6 & 146 & 184 & 151 & -- & -- & -- & -- \\
\hline 6 & $\ln (\mathrm{L})=1.56 \ln (\mathrm{Q})+0.057 \ln \left(\mathrm{Q}^{2}\right)-0.137 \mathrm{~T}+1.62$ & 36 & 0.964 & 0.812 & 95.6 & 4.44 & 1.48 & 5.14 & 6.39 & -- & -- & -- & -- & -- \\
\hline 7 & $\ln (\mathrm{L})=1.65 \ln (\mathrm{Q})+0.170 \sin (2 \pi \mathrm{T})-0.400 \cos (2 \pi \mathrm{T})+1.39$ & 51 & 0.957 & 0.910 & 82.4 & 8.14 & 3.22 & 10.6 & 10.5 & 9.44 & 12.9 & 4.95 & -- & 5.83 \\
\hline 9 & $\ln (\mathrm{L})=2.00 \ln (\mathrm{Q})+0.055 \ln \left(\mathrm{Q}^{2}\right)-0.194 \sin (2 \pi \mathrm{T})-0.406 \cos (2 \pi \mathrm{T})+3.98$ & 53 & 0.947 & 0.852 & 614 & 178 & 41.3 & 202 & 259 & 226 & 314 & 105 & 81.2 & 163 \\
\hline
\end{tabular}


Table 11. Regression models for estimating annual loads, flow-weighted concentrations, and densities of selected sampled water-quality constituents.-Continued

[ $n$, number of samples; $R^{2}$, coefficient of determination; RMSE, root mean squared error; $\mathrm{ft}^{3} / \mathrm{s}$, cubic feet per second; $\ln$, natural logarithm; L, instantaneous (daily) load; $\ln (\mathrm{Q})$, $\ln (\mathrm{streamflow}) \mathrm{minus}$ center of $\ln \left(\right.$ streamflow); $\ln \left(\mathrm{Q}^{2}\right)$, ln of streamflow squared; T, decimal time minus center of decimal time; $\mathrm{T}^{2}$, decimal time squared; sin, sine; cos, cosine; --, no data; E. coli, Escherichia coli; mL, milliliters; for purposes of load calculation, recorded zero average daily streamflows were assigned a minimal value of $\left.0.01 \mathrm{ft}^{3} / \mathrm{s}\right]$

\begin{tabular}{|c|c|c|c|c|c|c|c|c|c|c|c|c|c|c|c|c|}
\hline \multirow{2}{*}{$\begin{array}{c}\text { Site number } \\
\text { (table 2; } \\
\text { fig. 1) }\end{array}$} & \multicolumn{8}{|c|}{ Estimated annual $^{2}$ load $^{3}$} & \multicolumn{8}{|c|}{ Estimated annual ${ }^{2}$ flow-weighted concentration ${ }^{4}$} \\
\hline & 2006 & 2007 & 2008 & 2009 & 2010 & 2011 & 2012 & 2013 & 2006 & 2007 & 2008 & 2009 & 2010 & 2011 & 2012 & 2013 \\
\hline \multicolumn{17}{|c|}{ Total dissolved solids } \\
\hline 1 & 2,166 & 3,041 & 3,790 & 3,421 & 3,553 & 2,402 & 2,607 & 2,647 & 1,123 & 539 & 444 & 417 & 409 & 511 & 973 & 617 \\
\hline 2 & -- & -- & -- & -- & 22,400 & 9,320 & 8,340 & 11,600 & -- & -- & -- & -- & 148 & 230 & 210 & 134 \\
\hline 3 & -- & -- & -- & 2,570 & 2,900 & 1,550 & 1,550 & 2,150 & -- & -- & -- & 424 & 406 & 442 & 454 & 467 \\
\hline${ }^{5} 4$ & -- & -- & -- & -- & -- & 3,140 & 2,090 & 5,570 & -- & -- & -- & -- & -- & 224 & 230 & 214 \\
\hline 5 & 8,130 & 31,700 & 40,400 & 36,100 & -- & -- & -- & -- & 318 & 242 & 245 & 268 & -- & -- & -- & -- \\
\hline 6 & 523 & 1,410 & 1,640 & -- & -- & -- & -- & -- & 395 & 307 & 287 & -- & -- & -- & -- & -- \\
\hline${ }^{5} 7$ & 1,410 & 4,270 & 3,640 & 3,440 & 4,190 & 1,830 & -- & 1,810 & 490 & 452 & 387 & 408 & 363 & 414 & -- & 348 \\
\hline 9 & 11,700 & 46,800 & 61,000 & 56,700 & 72,600 & 29,500 & 23,400 & 40,600 & 317 & 259 & 264 & 281 & 259 & 315 & 323 & 279 \\
\hline \multicolumn{17}{|c|}{ Chloride } \\
\hline 1 & 130 & 300 & 361 & 410 & 459 & 257 & 201 & 265 & 67.4 & 53.2 & 42.2 & 50.0 & 52.8 & 54.7 & 74.8 & 61.8 \\
\hline $5_{2}$ & -- & -- & -- & -- & 7,360 & 2,460 & 2,570 & 7,070 & -- & -- & -- & -- & 48.5 & 60.7 & 64.5 & 81.8 \\
\hline 3 & -- & -- & -- & 799 & 865 & 479 & 472 & 699 & -- & -- & -- & 132.0 & 121.2 & 136.5 & 138.0 & 152.0 \\
\hline${ }^{5} 4$ & -- & -- & -- & -- & -- & 542 & 378 & 1,310 & -- & -- & -- & -- & -- & 38.7 & 41.4 & 50.4 \\
\hline 5 & 1,650 & 5,950 & 7,560 & 7,020 & -- & -- & -- & -- & 64.6 & 45.5 & 45.8 & 52.0 & -- & -- & -- & -- \\
\hline${ }^{5} 6$ & 108 & 296 & 328 & -- & -- & -- & -- & -- & 81.7 & 64.5 & 57.3 & -- & -- & -- & -- & -- \\
\hline 7 & 239 & 851 & 727 & 729 & 950 & 450 & -- & 503 & 83.1 & 90.1 & 77.0 & 86.5 & 82.4 & 101.8 & -- & 96.6 \\
\hline $5_{9}$ & 2,370 & 9,300 & 12,100 & 11,600 & 14,100 & 6,460 & 5,170 & 8,360 & 64.3 & 51.6 & 52.2 & 57.5 & 50.3 & 68.9 & 71.1 & 57.4 \\
\hline \multicolumn{17}{|c|}{ Ammonia } \\
\hline 1 & 0.160 & 0.792 & 0.721 & 0.566 & 0.518 & 0.317 & 0.140 & 0.424 & 0.083 & 0.140 & 0.084 & 0.069 & 0.060 & 0.067 & 0.052 & 0.099 \\
\hline $7_{2}$ & -- & -- & -- & -- & 1.84 & 1.48 & 2.51 & 8.42 & -- & -- & -- & -- & 0.012 & 0.037 & 0.063 & 0.097 \\
\hline${ }^{73}$ & -- & -- & -- & 0.189 & 0.304 & 0.197 & 0.245 & 0.427 & -- & -- & -- & 0.031 & 0.043 & 0.056 & 0.072 & 0.093 \\
\hline 4 & -- & -- & -- & -- & -- & 0.880 & 0.601 & 1.47 & -- & -- & -- & -- & -- & 0.063 & 0.066 & 0.057 \\
\hline 5 & 2.20 & 12.2 & 11.4 & 7.95 & -- & -- & -- & -- & 0.086 & 0.093 & 0.069 & 0.059 & -- & -- & -- & -- \\
\hline${ }^{7} 6$ & 0.131 & 0.681 & 0.663 & -- & -- & -- & -- & -- & 0.099 & 0.148 & 0.116 & -- & -- & -- & -- & -- \\
\hline${ }^{77}$ & 0.123 & 0.784 & 0.583 & 0.589 & 0.698 & 0.277 & -- & 0.399 & 0.043 & 0.083 & 0.062 & 0.070 & 0.061 & 0.063 & -- & 0.077 \\
\hline 79 & 2.28 & 19.4 & 12.5 & 8.98 & 12.0 & 3.53 & 2.96 & 12.8 & 0.062 & 0.108 & 0.054 & 0.044 & 0.043 & 0.038 & 0.041 & 0.088 \\
\hline
\end{tabular}


Table 11. Regression models for estimating annual loads, flow-weighted concentrations, and densities of selected sampled water-quality constituents.-Continued

$\left[n\right.$, number of samples; $R^{2}$, coefficient of determination; RMSE, root mean squared error; $\mathrm{ft} / \mathrm{s}$, cubic feet per second; ln, natural logarithm; L, instantaneous (daily) load; $\ln (\mathrm{Q})$, $\ln ($ streamflow) minus center of $\ln \left(\right.$ streamflow); $\ln \left(\mathrm{Q}^{2}\right)$, ln of streamflow squared; T, decimal time minus center of decimal time; $\mathrm{T}^{2}$, decimal time squared; sin, sine; cos, cosine; --, no data; E. coli, Escherichia coli; mL, milliliters; for purposes of load calculation, recorded zero average daily streamflows were assigned a minimal value of $\left.0.01 \mathrm{ft}^{3} / \mathrm{s}\right]$

\begin{tabular}{|c|c|c|c|c|c|c|c|c|c|c|c|c|c|c|c|c|}
\hline \multirow{2}{*}{$\begin{array}{l}\text { Site number } \\
\text { (table 2; } \\
\text { fig. 1) }\end{array}$} & \multicolumn{8}{|c|}{ Estimated annual ${ }^{2}$ load $^{3}$} & \multicolumn{8}{|c|}{ Estimated annual ${ }^{2}$ flow-weighted concentration ${ }^{4}$} \\
\hline & 2006 & 2007 & 2008 & 2009 & 2010 & 2011 & 2012 & 2013 & 2006 & 2007 & 2008 & 2009 & 2010 & 2011 & 2012 & 2013 \\
\hline \multicolumn{17}{|c|}{ Nitrate plus nitrite } \\
\hline 1 & 1.35 & 3.81 & 5.67 & 5.65 & 6.08 & 3.34 & 1.94 & 2.96 & 0.700 & 0.675 & 0.664 & 0.688 & 0.700 & 0.711 & 0.724 & 0.691 \\
\hline 2 & -- & -- & -- & -- & 58.7 & 18.2 & 23.2 & 71.4 & -- & -- & -- & -- & 0.387 & 0.449 & 0.584 & 0.826 \\
\hline 3 & -- & -- & -- & 1.21 & 1.42 & 0.698 & 0.682 & 0.915 & -- & -- & -- & 0.200 & 0.199 & 0.199 & 0.200 & 0.199 \\
\hline${ }^{84}$ & -- & -- & -- & -- & -- & 3.38 & 2.15 & 6.63 & -- & -- & -- & -- & -- & 0.241 & 0.236 & 0.255 \\
\hline 5 & 7.59 & 67.7 & 64.4 & 43.6 & -- & -- & -- & -- & 0.297 & 0.518 & 0.391 & 0.323 & -- & -- & -- & -- \\
\hline 6 & 0.874 & 3.03 & 3.77 & -- & -- & -- & -- & -- & 0.661 & 0.660 & 0.661 & -- & -- & -- & -- & -- \\
\hline${ }^{87}$ & 1.37 & 4.95 & 4.94 & 4.40 & 6.03 & 2.30 & -- & 2.72 & 0.476 & 0.524 & 0.525 & 0.522 & 0.523 & 0.520 & -- & 0.522 \\
\hline 9 & 11.8 & 94.6 & 115 & 93.8 & 140.0 & 37.6 & 28.1 & 68.1 & 0.320 & 0.524 & 0.497 & 0.465 & 0.499 & 0.401 & 0.388 & 0.468 \\
\hline \multicolumn{17}{|c|}{ Organic nitrogen } \\
\hline 1 & 1.99 & 14.2 & 22.8 & 10.9 & 10.4 & 6.41 & 1.90 & 4.96 & 1.03 & 2.52 & 2.67 & 1.33 & 1.20 & 1.36 & 0.71 & 1.16 \\
\hline 2 & -- & -- & -- & -- & 299 & 37.6 & 47.9 & 178 & -- & -- & -- & -- & 1.97 & 0.93 & 1.21 & 2.06 \\
\hline 3 & -- & -- & -- & 3.65 & 4.59 & 2.15 & 2.32 & 3.41 & -- & -- & -- & 0.603 & 0.643 & 0.613 & 0.680 & 0.741 \\
\hline$s_{4}$ & -- & -- & -- & -- & -- & 8.47 & 5.20 & 18.3 & -- & -- & -- & -- & -- & 0.605 & 0.571 & 0.703 \\
\hline 5 & 14.2 & 300 & 251 & 156 & -- & -- & -- & -- & 0.556 & 2.29 & 1.52 & 1.16 & -- & -- & -- & -- \\
\hline 6 & 1.28 & 8.76 & 8.67 & -- & -- & -- & -- & -- & 0.968 & 1.91 & 1.52 & -- & -- & -- & -- & -- \\
\hline 7 & 2.80 & 22.8 & 22.5 & 12.2 & 19.6 & 4.50 & -- & 7.32 & 0.97 & 2.41 & 2.39 & 1.45 & -- & 1.02 & -- & 1.41 \\
\hline 9 & 24.30 & 601 & 521 & 328 & 646 & 92.7 & 68.8 & 262 & 0.659 & 3.33 & 2.25 & 1.63 & 2.30 & 0.989 & 0.949 & 1.80 \\
\hline \multicolumn{17}{|c|}{ Total phosphorous } \\
\hline 1 & 0.81 & 4.26 & 8.84 & 3.71 & 3.77 & 2.34 & 0.76 & 1.67 & 0.420 & 0.755 & 1.035 & 0.452 & 0.434 & 0.498 & 0.284 & 0.390 \\
\hline 2 & -- & -- & -- & -- & 132 & 10.7 & 22.1 & 100 & -- & -- & -- & -- & 0.871 & 0.264 & 0.556 & 1.157 \\
\hline 3 & -- & -- & -- & 0.625 & 0.704 & 0.285 & 0.364 & 0.643 & -- & -- & -- & 0.103 & 0.099 & 0.081 & 0.107 & 0.140 \\
\hline 4 & -- & -- & -- & -- & -- & 1.55 & 1.57 & 3.35 & -- & -- & -- & -- & -- & 0.111 & 0.173 & 0.129 \\
\hline 5 & 3.67 & 130 & 91.0 & 51.4 & -- & -- & -- & -- & 0.144 & 0.993 & 0.552 & 0.381 & -- & -- & -- & -- \\
\hline 6 & 0.444 & 3.56 & 3.39 & -- & -- & -- & -- & -- & 0.336 & 0.776 & 0.594 & -- & -- & -- & -- & -- \\
\hline 7 & 1.49 & 9.45 & 12.0 & 5.40 & 9.88 & 2.13 & & 3.17 & 0.518 & 1.000 & 1.274 & 0.641 & 0.857 & 0.482 & -- & 0.609 \\
\hline 9 & 7.70 & 359 & 305 & 135 & 348 & 28.7 & 25.2 & 115 & 0.209 & 1.990 & 1.319 & 0.669 & 1.241 & 0.306 & 0.348 & 0.790 \\
\hline
\end{tabular}


Table 11. Regression models for estimating annual loads, flow-weighted concentrations, and densities of selected sampled water-quality constituents.-Continued

[ $n$, number of samples; $R^{2}$, coefficient of determination; RMSE, root mean squared error; $\mathrm{ft}^{3} / \mathrm{s}$, cubic feet per second; $\ln$, natural logarithm; $\mathrm{L}$, instantaneous (daily) load; $\ln (\mathrm{Q})$, $\ln (\mathrm{streamflow})$ minus center of $\ln \left(\right.$ streamflow); $\ln \left(\mathrm{Q}^{2}\right)$, ln of streamflow squared; T, decimal time minus center of decimal time; $\mathrm{T}^{2}$, decimal time squared; sin, sine; cos, cosine; --, no data; E. coli, Escherichia coli; mL, milliliters; for purposes of load calculation, recorded zero average daily streamflows were assigned a minimal value of $\left.0.01 \mathrm{ft}^{3} / \mathrm{s}\right]$

\begin{tabular}{|c|c|c|c|c|c|c|c|c|c|c|c|c|c|c|c|c|}
\hline \multirow{2}{*}{$\begin{array}{c}\text { Site number } \\
\text { (table 2; } \\
\text { fig. 1) }\end{array}$} & \multicolumn{8}{|c|}{ Estimated annual ${ }^{2}$ load $^{3}$} & \multicolumn{8}{|c|}{ Estimated annual ${ }^{2}$ flow-weighted concentration ${ }^{4}$} \\
\hline & 2006 & 2007 & 2008 & 2009 & 2010 & 2011 & 2012 & 2013 & 2006 & 2007 & 2008 & 2009 & 2010 & 2011 & 2012 & 2013 \\
\hline \multicolumn{17}{|c|}{ Total nitrogen } \\
\hline 1 & 6.65 & 19.2 & 37.7 & 21.5 & 22.6 & 14.4 & 8.2 & 12.0 & 3.45 & 3.40 & 4.42 & 2.62 & 2.60 & 3.07 & 3.05 & 2.80 \\
\hline 2 & -- & -- & -- & -- & 360 & 62.2 & 75.9 & 294 & -- & -- & -- & -- & 2.37 & 1.54 & 1.91 & 3.40 \\
\hline 3 & -- & -- & -- & 4.93 & 6.34 & 3.12 & 3.41 & 5.12 & -- & -- & -- & 0.814 & 0.889 & 0.889 & 1.000 & 1.11 \\
\hline 4 & -- & -- & -- & -- & -- & 12.3 & 7.86 & 25.2 & -- & -- & -- & -- & -- & 0.878 & 0.864 & 0.969 \\
\hline $5_{5}$ & 22.9 & 296 & 318 & 221 & -- & -- & -- & -- & 0.897 & 2.26 & 1.93 & 1.64 & -- & -- & -- & -- \\
\hline 6 & 2.57 & 12.8 & 14.1 & -- & -- & -- & -- & -- & 1.94 & 2.79 & 2.47 & -- & -- & -- & -- & -- \\
\hline 7 & 5.01 & 30.4 & 29.4 & 20.8 & 30.5 & 8.82 & -- & 12.9 & 1.74 & 3.22 & 3.12 & 2.47 & 2.65 & 2.00 & -- & 2.48 \\
\hline 9 & 36.7 & 659 & 611 & 440 & 757 & 142 & 104 & 331 & 1.00 & 3.65 & 2.64 & 2.18 & 2.70 & 1.51 & 1.43 & 2.27 \\
\hline \multicolumn{17}{|c|}{ E. coli (colonies $/ 100 \mathrm{~mL})^{9}$} \\
\hline 1 & 254,000 & $1,960,000$ & $6,530,000$ & $1,880,000$ & $2,230,000$ & $1,680,000$ & 282,000 & 738,000 & 13,168 & 34,729 & 76,490 & 22,908 & 25,665 & 35,766 & 10,526 & 17,217 \\
\hline 2 & -- & -- & -- & -- & $146,000,000$ & $2,060,000$ & $12,400,000$ & $31,900,000$ & -- & -- & -- & -- & 96,303 & 5,087 & 31,218 & 36,896 \\
\hline 3 & -- & -- & -- & 38,700 & 110,000 & 55,400 & 123,000 & 105,000 & -- & -- & -- & 639 & 1,542 & 1,579 & 3,606 & 2,283 \\
\hline 4 & -- & -- & -- & -- & -- & 85,800 & 29,900 & 112,000 & -- & -- & -- & -- & -- & 613 & 329 & 431 \\
\hline 5 & 597,000 & $17,800,000$ & $26,800,000$ & $10,000,000$ & -- & -- & -- & -- & 2,338 & 13,615 & 16,275 & 7,411 & -- & -- & -- & -- \\
\hline 6 & 103,000 & 567,000 & $1,350,000$ & -- & -- & -- & -- & -- & 7,793 & 12,353 & 23,658 & -- & -- & -- & -- & -- \\
\hline 7 & 483,000 & $1,910,000$ & $4,490,000$ & $1,240,000$ & $2,970,000$ & 560,000 & -- & 659,000 & 16,797 & 20,216 & 47,704 & 14,710 & 25,762 & 12,669 & -- & 12,658 \\
\hline 9 & $1,940,000$ & $86,700,000$ & $168,000,000$ & $29,300,000$ & $126,000,000$ & $4,000,000$ & $8,670,000$ & $27,000,000$ & 5,261 & 48,064 & 72,637 & 14,518 & 44,935 & 4,266 & 11,957 & 18,549 \\
\hline \multicolumn{17}{|c|}{ Suspended sediment } \\
\hline 1 & 471 & 4,030 & 8,060 & 2,980 & 2,820 & 1,700 & 411 & 905 & 244 & 714 & 944 & 363 & 325 & 362 & 153 & 211 \\
\hline 2 & -- & -- & -- & -- & 250,000 & 10,300 & 16,700 & 80,900 & -- & -- & -- & -- & 1,649 & 254 & 420 & 936 \\
\hline 3 & -- & -- & -- & 470 & 555 & 240 & 248 & 348 & -- & -- & -- & 77.6 & 77.8 & 68.4 & 72.7 & 75.7 \\
\hline 4 & -- & -- & -- & -- & -- & 998 & 960 & 922 & -- & -- & -- & -- & -- & 71.3 & 105 & 35.4 \\
\hline 5 & 2,560 & 194,000 & 80,800 & 33,700 & -- & -- & -- & -- & 100 & 1,484 & 491 & 250 & -- & -- & -- & -- \\
\hline 6 & 390 & 4,470 & 4,020 & -- & -- & -- & -- & -- & 295 & 974 & 704 & -- & -- & -- & -- & -- \\
\hline 7 & 1,650 & 14,500 & 13,600 & 8,260 & 12,900 & 2,970 & -- & 5,170 & 574 & 1,535 & 1,445 & 980 & 1,119 & 672 & -- & 993 \\
\hline 9 & 7,010 & 808,000 & 523,000 & 219,000 & 635,000 & 35,100 & 30,000 & 206,000 & 190 & 4,479 & 2,261 & 1,085 & 2,265 & 374 & 414 & 1,415 \\
\hline
\end{tabular}

'RMSE is calculated from the estimated residual variance of the model.

${ }^{2}$ Water year, October 1 of previous year through September 30 .

${ }^{3}$ Estimated loads are given in metric tons (megagram) except for E. coli loads, which are in billions of colonies.

${ }^{4}$ Estimated flow-weighted concentrations are given in milligrams per liter $(\mathrm{mg} / \mathrm{L})$ except for $E$. coli concentrations that are in colonies per 100 milliliters.

${ }^{5}$ Model does not meet the Turnbull-Weiss normality test criteria for Adjusted Maximum Likelihood Estimation (AMLE) method. Least Absolute Deviation (LAD) method used to estimate loads.

${ }^{6}$ Streamflow measurements begin on November 20, 2009.

${ }^{7}$ Model does not meet the Turnbull-Weiss normality test criteria due to the large proportion of censored values. Visual inspection indicates acceptable distribution of the residuals.

${ }^{8}$ Model does not meet the Turnbull-Weiss normality test criteria for the AMLE method. Less than values were assigned concentration values equal to the detection limit of $0.04 \mathrm{mg} / \mathrm{L}$ before applying the LAD method.

${ }^{9}$ For purposes of this report, colonies per $100 \mathrm{~mL}$ is considered equivalent to most probable number per $100 \mathrm{~mL}$. 
samples, with total organic $\mathrm{N}$ accounting for 37 percent and dissolved nitrate for 46 percent (table 9). Median dissolved $\mathrm{P}$ accounted for 68 percent of median total $P$ for base-flow samples (table 9). Sites 1 and 11 had the highest measured values for nitrate plus nitrite, nitrate, nitrite, total N, orthophosphate, and dissolved and total $\mathrm{P}$ in base-flow samples (appendix 1).

Median dissolved $\mathrm{P}$ was 68 percent of median total $\mathrm{P}$ for baseflow samples.

Concentrations of nutrients, including total $\mathrm{N}$ and $\mathrm{P}$, in stormflow are summarized in table 10. Sites 1 and 7 had the highest median concentrations $(3.2 \mathrm{mg} / \mathrm{L})$ of total $\mathrm{N}$ in stormflow, and median total $\mathrm{N}$ concentrations at all other sites ranged between $1.2 \mathrm{mg} / \mathrm{L}$ and $2.8 \mathrm{mg} / \mathrm{L}$. During the study period, total organic $\mathrm{N}$ and dissolved nitrate accounted for 98 percent of the median total $\mathrm{N}$ in stormflow samples, with 78 percent being total organic $\mathrm{N}$ and 20 percent being dissolved nitrate. Although the highest total $\mathrm{P}$ concentration $(1.29 \mathrm{mg} / \mathrm{L}$ as $\mathrm{P})$ in stormflow samples was measured at site 11 , there was only one sample collected at that site during the study period so no median value was calculated. Site 7 had the highest median total P concentration $(1.19 \mathrm{mg} / \mathrm{L})$ in stormflow samples and median total $\mathrm{P}$ at all other sites ranged from 0.188 to $0.851 \mathrm{mg} / \mathrm{L}$ (table 10 ). Median dissolved P accounted for only about 13 percent of median total $\mathrm{P}$ in stormflow samples (table 10). Site 7 had the highest measured concentrations for total $\mathrm{N}$ and total $\mathrm{P}$, ammonia plus organic $\mathrm{N}$, and total organic $\mathrm{N}$ (appendix 2). These concentrations were all recorded from one May 2006 sample that also had a high SSC $(71,600 \mathrm{mg} / \mathrm{L})$. The lowest median concentration of total $\mathrm{N}$ $(1.2 \mathrm{mg} / \mathrm{L})$ in stormflow samples was measured at sites 3 and 4 , and site 3 also had the lowest median concentration of total $\mathrm{P}(0.188 \mathrm{mg} / \mathrm{L})$.

The EPA proposed provisional nutrient standards for level III ecoregion 40 streams, including those in Independence are $0.86 \mathrm{mg} / \mathrm{L}$ for total $\mathrm{N}$ and $0.09 \mathrm{mg} / \mathrm{L}$ for total P(U.S. Environmental Protection Agency, 2000). Nutrient concentrations in base-flow samples from the smaller streams in Independence (sites 1, 3, 4, 6, 7, 8, and 11) exceeded the EPA standards for total $\mathrm{N}$ in 52 percent of samples and total $\mathrm{P}$ in 48 percent of samples (appendix 1). Base-flow nutrient concentrations at the Little Blue River sites (Lee's Summit Road, site 2; 39th Street, site 5; and Lake City, site 9) exceeded the EPA standards for total $\mathrm{N}$ in 24 percent of samples and total $\mathrm{P}$ in 30 percent of samples.

Nutrient concentrations in stormflow on the smaller streams (sites 1, 3, 4, 6, 7, 8, and 11) exceeded the EPA provisional standards for total N $(0.86 \mathrm{mg} / \mathrm{L}$; U.S. Environmental Protection Agency, 2000) in about 93 percent of samples and total $\mathrm{P}(0.09 \mathrm{mg} / \mathrm{L})$ in about 94 percent of samples (appendix 2). Nutrient concentrations in stormflow at the Little Blue River sites (sites 2, 5, and 9) exceeded the EPA provisional standards for total $\mathrm{N}$ in about 92 percent of samples and total $\mathrm{P}$ in about 97 percent of samples.

Site 9 had the highest estimated annual loads during most years for nutrient constituents (total $\mathrm{N}$, total organic $\mathrm{N}$, nitrate plus nitrite, ammonia, and total $\mathrm{P}$ ) and the highest annual average daily streamflow (table 11). The only exception was the estimated annual load of nitrate plus nitrite, which was higher at site 2 in 2013. The estimated annual load of all nutrient constituents consistently increased each year from 2011 to 2013 at site 2, but decreased at site 9 from 2011 to 2012 and then increased in 2013.

The estimated annual flow-weighted concentrations for most nutrient constituents were highest at sites 1 or 9 for the period of WYs 2006 to 2011, and highest at sites 1 or 2 from WYs 2012 to 2013. Exceptions to this were estimated annual flow-weighted concentrations for ammonia during all years except WYs 2011 and 2013, and total P during WY 2006. Site 6 had the highest estimated annual flow-weighted concentration of ammonia for all years of operation of the site (WYs 2006 to 2008). From WYs 2012 to 2013, the estimated annual flow-weighted concentrations of nutrient constituents (total N, total organic $\mathrm{N}$, nitrate plus nitrite, ammonia, and total $\mathrm{P}$ ) were higher on the Little Blue River at site 2 than downstream at site 9. Site 1 had the highest estimated annual flow-weighted concentration for at least one nutrient constituent nearly onehalf the time from WYs 2006 to 2013. In WY 2011, all estimated annual flow-weighted concentrations for nutrients were highest at site 1 . Nitrate plus nitrite was consistently higher at site 1, except in WY 2013. The highest estimated annual flow-weighted concentrations for the study period from WYs 2006 to 2013 for most nutrient constituents were highest during WYs 2007 and 2008. The only exception was nitrate plus nitrite, which was highest during WYs 2012 and 2013. Sites 3 and 4, beginning with their installment in WYs 2009 and 2011, had the lowest estimated annual flow-weighted concentrations during most years and for most nutrient constituents, except ammonia in WYs 2012 and 2013.

\section{Total Recoverable Metals}

Total recoverable aluminum, cadmium, chromium, copper, lead, zinc, arsenic, and dissolved mercury were analyzed in base-flow and stormflow samples from sites 1 through 9 and 11. Total recoverable metals are determined from an unfiltered sample that includes both dissolved and suspended material. The Missouri AQL standards are only for dissolved metals rather than total recoverable metals (except for mercury, which is a dissolved metals standard), and are $\mathrm{pH}$ and hardness dependent and therefore vary by sample (Missouri Department of Natural Resources, 2014b). Hardness was not analyzed in base-flow or stormflow samples collected for the project during WYs 2005 to 2013. The total recoverable metals results were therefore unable to be compared to the Missouri AQL standards. Concentrations for most total recoverable metals, except aluminum, in base-flow samples were generally low and were less than $5 \mu \mathrm{g} / \mathrm{L}$ (appendix 1). Concentrations for most total recoverable metals, except aluminum, in stormflow generally were higher but were less than $80 \mu \mathrm{g} / \mathrm{L}$ (appendix 2).

Among trace elements analyzed in base-flow and stormflow samples, total recoverable aluminum concentrations were 
Table 12. Categories of common organic micro-constituents detected in urban streams.

[PAH, polycyclic aromatic hydrocarbon; categories adopted from Zaugg and others, 2002; Lee and others, 2005; Wilkison and others, 2006]

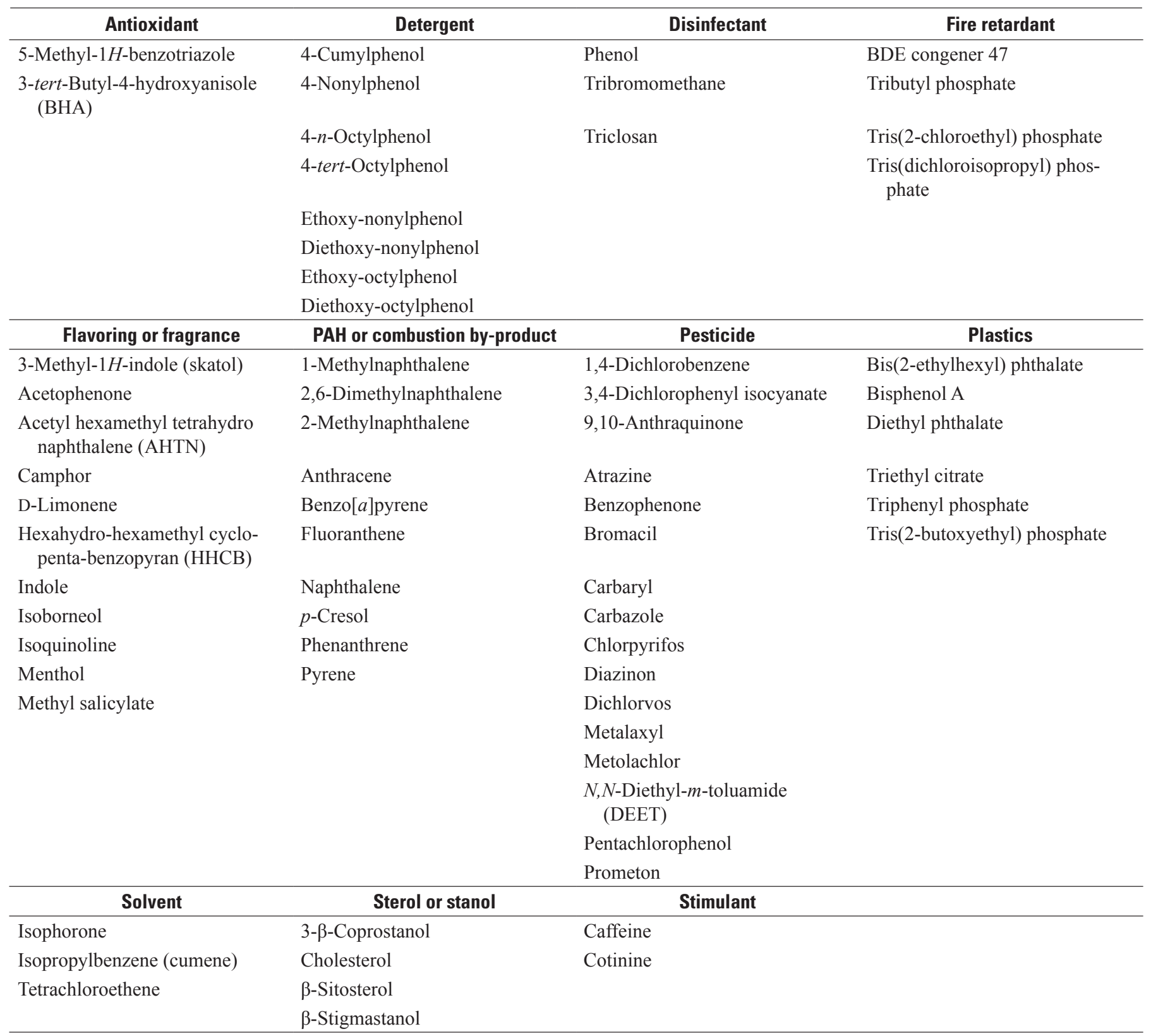

highest. Total recoverable aluminum concentrations ranged from $7 \mu \mathrm{g} / \mathrm{L}$ to $1,420 \mu \mathrm{g} / \mathrm{L}$ in base flow (table 9), and $8.5 \mu \mathrm{g} / \mathrm{L}$ to $170,000 \mu \mathrm{g} / \mathrm{L}$ in stormflow (table 10 ), at least two orders of magnitude greater than the combined total of all other metals. The highest concentration of total recoverable aluminum $(170,000 \mu \mathrm{g} / \mathrm{L})$ was measured in a stormflow sample from site 7 in March 2006, which also had the highest SSC (appendix 2). In October 2007, dissolved metals were analyzed in one set of stormflow samples in addition to total recoverable metals. The dissolved metals concentrations were lower than the total recoverable metals concentrations, and did not exceed
Missouri standards for AQL (Missouri Department of Natural Resources, 2014b).

\section{Common Organic Micro-Constituents and Pesticides in Streambed Sediment and Surface Water}

At sites 1 through 9 and 11 (table 2; fig. 1), 71 base-flow samples were analyzed between June 2006 and July 2013 for 11 categories of OMCs (table 12). Four categories of OMCs were detected in 50 percent or more of base-flow samples; 
polyaromatic hydrocarbons (PAHs) and combustion products (66 percent), pesticides (100 percent), plastics (52 percent), and sterols and stanols (72 percent; table 13). Most detections of OMCs were not quantified because they were at or near the NWQL LRL (appendix 1). Pesticides detected in at least one-half of all base-flow samples were atrazine (76 percent), DEET (76 percent) and prometon (59 percent); 3,4-dichlorophenyl isocyanate also was detected about one-half of the time (49 percent; appendix 1). The sterol or stanol cholesterol also was detected in low concentrations in 72 percent of base-flow samples. All other OMCs were detected less than one-half of the time. The median concentration of total OMCs of all base-flow samples was $0.06 \mu \mathrm{g} / \mathrm{L}$, with a minimum combined concentration of $0.003 \mu \mathrm{g} / \mathrm{L}$ and a maximum of $53.3 \mu \mathrm{g} / \mathrm{L}$ (table 13).

Common organic microconstituents were analyzed in 130 stormflow samples collected from Independence streams from June 2005 to September 2013 (table 14). The median total OMC concentration for all stormflow samples $(0.13 \mu \mathrm{g} / \mathrm{L})$ was higher than that of base-flow $(0.06 \mu \mathrm{g} / \mathrm{L}$; table 13). Five categories of OMCs had detections more than 90 percent of the time; PAHs and combustion products (97 percent), pesticides (100 percent), plastics (95 percent), sterols or stanols (90 percent), and stimulants (94 percent). Most detections of OMCs in stormflow were less than $2 \mu \mathrm{g} / \mathrm{L}$ or less than the NWQL LRL for the constituent and not quantified (appendix 2). The most commonly detected pesticides were DEET (95 percent) and 9,10-anthraquinone (96 percent), and the most commonly detected PAHs or combustion products were fluoranthene ( 94 percent) and pyrene ( 92 percent; data on file at the USGS Water Science Center in Lee's Summit). The stimulant caffeine was also detected 93 percent of the time. The pesticide 3,4-dichlorophenyl isocyanate had the highest median concentration $(0.48 \mu \mathrm{g} / \mathrm{L})$ and was detected 73 percent of the time. The PAH or combustion product fluoranthene had the highest median concentration $(0.26 \mu \mathrm{g} / \mathrm{L})$ and was the most frequently detected. The detergent diethoxynonylphenol (all isomers) had the highest median concentration $(1.12 \mu \mathrm{g} / \mathrm{L})$ of all OMCs, and was detected in 28 percent of samples (appendix 2). Sites 1 and 6 had the highest median detections of total OMCs in stormflow $(0.16 \mu \mathrm{g} / \mathrm{L}$, table 14$)$. The combined minimum concentration of all OMCs in stormflow was $0.002 \mu \mathrm{g} / \mathrm{L}$ and the combined maximum was $26.4 \mu \mathrm{g} / \mathrm{L}$. All stormflow samples had at least one quantified detection of at least one OMC compound (appendix 2).

Fourteen base-flow samples were analyzed for pesticides (table 15) in streambed sediment at all sites in July 2010, two sites (sites 2 and 9) in April 2011, and two sites (sites 1 and 9) in September 2012 and July 2013. One-half of the constituents analyzed (11 of 22) had detections in one or more samples and trans-chlordane had the most detections (table 16). Of the sites sampled in July 2010, sites 3 and 4 had no pesticide detections (appendix 1).

Two base-flow samples and 17 stormflow samples were analyzed for pesticides in water. Base-flow samples were analyzed for two sites on the Little Blue River (sites 2 and
9) in April 2011. Stormflow samples were analyzed for all sites (sites 1 through 9 and 11) in September 2010; sites 3 and 9 in June 2011, and sites 1 and 9 in August and November 2011 and June 2012 and 2013. Twenty-six constituents were analyzed (table 15), and none had measureable detections in either base flow or stormflow because all results were less than the NWQL LRL of the compound (appendix 2).

\section{Fecal Indicator Bacteria, Microbial Source Tracking, and Suspended Sediment}

Fecal indicator bacteria were analyzed in 159 base-flow and 168 stormflow samples collected from June 2005 to September 2013. E. coli, fecal coliform, and total coliform bacteria were analyzed at sites 1 through 9 and 11 between June 2005 and September 2013. Fecal coliform analysis was discontinued at the end of July 2010. Median E. Coli densities measured in base-flow samples ranged from $19 \mathrm{MPN} / 100 \mathrm{~mL}$ at site 3 to $410 \mathrm{MPN} / 100 \mathrm{~mL}$ at site 7 (table 9). Median fecal coliform densities in base-flow samples collected in June 2006 through July 2010 at sites 1 through 11 ranged from $4 \mathrm{col} / 100$ $\mathrm{mL}$ at site 3 to $530 \mathrm{col} / 100 \mathrm{~mL}$ at site 1 , and median total coliform densities ranged from 2,950 MPN/100 mL at site 2 to $33,000 \mathrm{MPN} / 100 \mathrm{~mL}$ at site 11 . The Little Blue River sites (sites 2, 5, and 9) had lower median FIB densities, including E. Coli, than sites 1, 6, 7, 8, and 11 (table 9), except site 3 , which is directly downstream from the spillway of a small lake, and site 4, located about 1.5 kilometers downstream from Blue Springs Lake.

Median E. Coli densities measured in stormflow samples at sites with multiple samples (sites 1 through 9) in August 2005 through September 2013 ranged from $1,200 \mathrm{MPN} / 100 \mathrm{~mL}$ at site 3 to $31,000 \mathrm{MPN} / 100 \mathrm{~mL}$ at site 1 (table 10). Median fecal coliform densities measured from August 2005 through July 2010 at sites 1 through 9 during stormflow ranged from $960 \mathrm{col} / 100 \mathrm{~mL}$ at site 3 to $42,000 \mathrm{col} / 100 \mathrm{~mL}$ at site 1 . Median total coliform densities ranged from $57,000 \mathrm{MPN} / 100 \mathrm{~mL}$ at site 3 to $1,190,000 \mathrm{MPN} / 100 \mathrm{~mL}$ at site 1 . Although site 11 had lower median measured $E$. Coli and total coliform concentrations than the lowest median concentrations given above, site 11 was not used for comparison because only one stormflow sample was collected during the study. The Little Blue River sites (sites 2, 5 and 9) had lower median FIB densities in stormflow than the smaller Independence streams (sites 1, 6 through 8, and 11) except sites 3 and 4 (table 10).

Estimated annual loads of $E$. Coli ranged from 29,900 billion colonies at site 4 during WY 2012 to 168,000,000 billion colonies at site 9 during WY 2008 (table 11). The estimated annual load of $E$. Coli was highest at site 9 during WYs 2006 through 2009 and 2011, and highest at site 2, located upstream from site 9 during WYs 2010, 2012, and 2013. Sites 2 and 9 both had higher annual daily average streamflow than the other Independence sites. Site 7 had the highest estimated annual flow-weighted concentration of 
Table 13. Summary of constituent concentrations by category of total common organic micro-constituents by site in base-flow samples, June 2006 through September 2013.

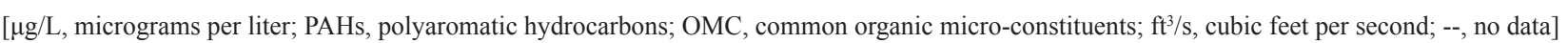

\begin{tabular}{|c|c|c|c|c|c|c|c|c|c|c|c|c|c|c|}
\hline $\begin{array}{l}\text { Site number } \\
\text { and number } \\
\text { of samples } \\
\text { (table 2; } \\
\text { fig. 1) }\end{array}$ & Statistic & $\begin{array}{c}\text { Total } \\
\text { antioxidants } \\
(\mu \mathrm{g} / \mathrm{L})\end{array}$ & $\begin{array}{c}\text { Total } \\
\text { detergents } \\
(\mu \mathrm{g} / \mathrm{L})\end{array}$ & $\begin{array}{c}\text { Total } \\
\text { disinfectants } \\
(\mu \mathrm{g} / \mathrm{L})\end{array}$ & $\begin{array}{c}\text { Total } \\
\text { fire } \\
\text { retardants } \\
(\mu \mathrm{g} / \mathrm{L})\end{array}$ & $\begin{array}{c}\text { Total } \\
\text { flavorings } \\
\text { and } \\
\text { fragrances } \\
\text { ( } \mu \mathrm{g} / \mathrm{L})\end{array}$ & $\begin{array}{c}\text { Total } \\
\text { PAHs and } \\
\text { combustion } \\
\text { products } \\
(\mu \mathrm{g} / \mathrm{L})\end{array}$ & $\begin{array}{c}\text { Total } \\
\text { pesticides } \\
(\mu \mathrm{g} / \mathrm{L})\end{array}$ & $\begin{array}{c}\text { Total } \\
\text { plastics } \\
\text { ( } \mu \mathrm{g} / \mathrm{L})\end{array}$ & $\begin{array}{c}\text { Total } \\
\text { solvents } \\
\text { ( } \mu \mathrm{g} / \mathrm{L})\end{array}$ & $\begin{array}{l}\text { Total } \\
\text { sterols and } \\
\text { stanols } \\
(\mu \mathrm{g} / \mathrm{L})\end{array}$ & $\begin{array}{c}\text { Total } \\
\text { stimulants } \\
(\mu \mathrm{g} / \mathrm{L})\end{array}$ & $\begin{array}{c}\text { Total } \\
\text { OMC } \\
(\mu \mathrm{g} / \mathrm{L})\end{array}$ & $\begin{array}{l}\text { Streamflow }{ }^{1} \\
\quad\left(\mathrm{ft}^{3} / \mathrm{s}\right)\end{array}$ \\
\hline \multirow[t]{6}{*}{ All (71) } & Detections $^{2}$ & 6 & 30 & 7 & 33 & 26 & 47 & 71 & 37 & 20 & 51 & 31 & 69 & -- \\
\hline & $\begin{array}{l}\text { Total individual } \\
\text { constituents detected }\end{array}$ & 6 & 40 & 7 & 45 & 32 & 135 & 303 & 57 & 20 & 107 & 40 & 792 & -- \\
\hline & Minimum $^{4}$ & 0.06 & 0.04 & 0.02 & 0.01 & 0.003 & 0.004 & 0.004 & 0.01 & 0.004 & 0.11 & 0.02 & 0.003 & 0 \\
\hline & Maximum $^{4}$ & 0.60 & 2.26 & 0.14 & 0.10 & 0.14 & 0.52 & 53.30 & 2.24 & 0.02 & 2.61 & 0.30 & 53.3 & 168 \\
\hline & Average $^{4}$ & 0.21 & 0.37 & 0.08 & 0.05 & 0.02 & 0.04 & 0.35 & 0.29 & 0.01 & 0.59 & 0.09 & 0.27 & 16 \\
\hline & Median $^{4}$ & 0.08 & 0.22 & 0.08 & 0.05 & 0.02 & 0.02 & 0.06 & 0.11 & 0.01 & 0.43 & 0.06 & 0.06 & 3.3 \\
\hline \multirow[t]{5}{*}{$1(12)$} & Detections ${ }^{2}$ & 2 & 8 & 2 & 4 & 5 & 10 & 12 & 9 & 2 & 9 & 6 & 12 & -- \\
\hline & Minimum $^{4}$ & 0.07 & 0.04 & 0.02 & 0.02 & 0.003 & 0.004 & 0.004 & 0.02 & 0.004 & 0.17 & 0.03 & 0.003 & 0.32 \\
\hline & Maximum $^{4}$ & 0.08 & 1.18 & 0.14 & 0.10 & 0.14 & 0.52 & 2.30 & 2.24 & 0.01 & 1.62 & 0.11 & 2.30 & 4.9 \\
\hline & Average $^{4}$ & 0.07 & 0.38 & 0.08 & 0.05 & 0.03 & 0.07 & 0.16 & 0.35 & 0.01 & 0.56 & 0.07 & 0.20 & 1.9 \\
\hline & Median $^{4}$ & 0.07 & 0.24 & 0.08 & 0.04 & 0.02 & 0.03 & 0.06 & 0.13 & 0.01 & 0.42 & 0.06 & 0.07 & 1.2 \\
\hline \multirow[t]{5}{*}{$2(5)$} & Detections $^{2}$ & 0 & 2 & 0 & 2 & 1 & 5 & 5 & 0 & 2 & 2 & 2 & 5 & -- \\
\hline & Minimum $^{4}$ & -- & 0.06 & -- & 0.04 & 0.02 & 0.01 & 0.01 & -- & 0.01 & 0.11 & 0.04 & 0.01 & 5.1 \\
\hline & Maximum $^{4}$ & -- & 0.12 & -- & 0.06 & 0.02 & 0.13 & 1.42 & -- & 0.01 & 0.37 & 0.04 & 1.42 & 87 \\
\hline & Average $^{4}$ & -- & 0.09 & -- & 0.05 & 0.02 & 0.03 & 0.12 & -- & 0.01 & 0.20 & 0.04 & 0.09 & 26 \\
\hline & Median $^{4}$ & -- & 0.09 & -- & 0.04 & 0.02 & 0.01 & 0.04 & -- & 0.01 & 0.15 & 0.04 & 0.04 & 21 \\
\hline \multirow[t]{5}{*}{$3(7)$} & Detections ${ }^{2}$ & 1 & 3 & 2 & 5 & 1 & 5 & 7 & 5 & 3 & 7 & 6 & 5 & -- \\
\hline & Minimum $^{4}$ & 0.08 & 0.23 & 0.07 & 0.01 & 0.09 & 0.01 & 0.01 & 0.01 & 0.01 & 0.23 & 0.03 & 0.01 & 0 \\
\hline & Maximum $^{4}$ & 0.08 & 1.08 & 0.11 & 0.07 & 0.09 & 0.03 & 2.84 & 1.05 & 0.02 & 2.61 & 0.29 & 2.84 & 22 \\
\hline & Average $^{4}$ & 0.08 & 0.66 & 0.09 & 0.05 & 0.09 & 0.02 & 0.15 & 0.27 & 0.02 & 0.86 & 0.13 & 0.26 & 2.2 \\
\hline & Median $^{4}$ & 0.08 & 0.66 & 0.09 & 0.06 & 0.09 & 0.02 & 0.05 & 0.17 & 0.02 & 0.60 & 0.11 & 0.06 & 0.87 \\
\hline \multirow[t]{5}{*}{$4(5)$} & Detections ${ }^{2}$ & 0 & 2 & 0 & 2 & 3 & 3 & 5 & 1 & 3 & 4 & 1 & 5 & -- \\
\hline & Minimum $^{4}$ & -- & 0.11 & -- & 0.03 & 0.01 & 0.01 & 0.02 & 0.05 & 0.01 & 0.13 & 0.05 & 0.01 & 0.02 \\
\hline & Maximum $^{4}$ & -- & 0.16 & -- & 0.09 & 0.02 & 0.10 & 0.66 & 0.17 & 0.01 & 0.82 & 0.05 & 0.82 & 36 \\
\hline & Average $^{4}$ & -- & 0.13 & -- & 0.05 & 0.01 & 0.03 & 0.11 & 0.11 & 0.01 & 0.38 & 0.05 & 0.13 & 10 \\
\hline & Median $^{4}$ & -- & 0.13 & -- & 0.03 & 0.01 & 0.01 & 0.06 & 0.11 & 0.01 & 0.32 & 0.05 & 0.06 & 4.6 \\
\hline
\end{tabular}


Table 13. Summary of constituent concentrations by category of total common organic micro-constituents by site in base-flow samples, June 2006 through September 2013 . Continued

[ $\mu \mathrm{g} / \mathrm{L}$, micrograms per liter; PAHs, polyaromatic hydrocarbons; OMC, common organic micro-constituents; $\mathrm{ft}^{3} / \mathrm{s}$, cubic feet per second; --, no data]

\begin{tabular}{|c|c|c|c|c|c|c|c|c|c|c|c|c|c|c|}
\hline $\begin{array}{l}\text { Site number } \\
\text { and number } \\
\text { of samples } \\
\text { (table 2; } \\
\text { fig. 1) }\end{array}$ & Statistic & $\begin{array}{c}\text { Total } \\
\text { antioxidants } \\
(\mu \mathrm{g} / \mathrm{L})\end{array}$ & $\begin{array}{c}\text { Total } \\
\text { detergents } \\
(\mu \mathrm{g} / \mathrm{L})\end{array}$ & $\begin{array}{c}\text { Total } \\
\text { disinfectants } \\
(\mu \mathrm{g} / \mathrm{L})\end{array}$ & $\begin{array}{c}\text { Total } \\
\text { fire } \\
\text { retardants } \\
(\mu \mathrm{g} / \mathrm{L})\end{array}$ & $\begin{array}{c}\text { Total } \\
\text { flavorings } \\
\text { and } \\
\text { fragrances } \\
\text { ( } \mu \mathrm{g} / \mathrm{L})\end{array}$ & $\begin{array}{c}\text { Total } \\
\text { PAHs and } \\
\text { combustion } \\
\text { products } \\
(\mu \mathrm{g} / \mathrm{L})\end{array}$ & $\begin{array}{c}\text { Total } \\
\text { pesticides } \\
(\mu \mathrm{g} / \mathrm{L})\end{array}$ & $\begin{array}{c}\text { Total } \\
\text { plastics } \\
\text { ( } \mu \mathrm{g} / \mathrm{L})\end{array}$ & $\begin{array}{c}\text { Total } \\
\text { solvents } \\
\text { ( } \mu \mathrm{g} / \mathrm{L})\end{array}$ & $\begin{array}{l}\text { Total } \\
\text { sterols and } \\
\text { stanols } \\
(\mu \mathrm{g} / \mathrm{L})\end{array}$ & $\begin{array}{c}\text { Total } \\
\text { stimulants } \\
(\mu \mathrm{g} / \mathrm{L})\end{array}$ & $\begin{array}{c}\text { Total } \\
\text { OMC } \\
\text { ( } \mu \mathrm{g} / \mathrm{L})\end{array}$ & $\begin{array}{c}\text { Streamflow } \\
\left(\mathrm{ft}^{3} / \mathrm{s}\right)\end{array}$ \\
\hline \multirow[t]{5}{*}{$5(7)$} & Detections $^{2}$ & 0 & 2 & 0 & 2 & 2 & 3 & 7 & 5 & 2 & 3 & 2 & 7 & -- \\
\hline & Minimum $^{4}$ & -- & 0.13 & -- & 0.02 & 0.01 & 0.01 & 0.01 & 0.01 & 0.01 & 0.32 & 0.04 & 0.01 & 8.5 \\
\hline & Maximum $^{4}$ & -- & 0.37 & -- & 0.06 & 0.05 & 0.05 & 4.33 & 1.80 & 0.01 & 1.24 & 0.06 & 4.33 & 90 \\
\hline & Average $^{4}$ & -- & 0.25 & -- & 0.04 & 0.02 & 0.03 & 0.29 & 0.40 & 0.01 & 0.88 & 0.05 & 0.28 & 24 \\
\hline & Median $^{4}$ & -- & 0.25 & -- & 0.05 & 0.01 & 0.03 & 0.08 & 0.08 & 0.01 & 0.94 & 0.05 & 0.06 & 19 \\
\hline \multirow[t]{5}{*}{$6(9)$} & Detections $^{2}$ & 1 & 4 & 2 & 6 & 5 & 7 & 9 & 7 & 2 & 5 & 2 & 9 & -- \\
\hline & Minimum $^{4}$ & 0.38 & 0.09 & 0.08 & 0.02 & 0.003 & 0.004 & 0.01 & 0.01 & 0.01 & 0.14 & 0.07 & 0.003 & 0.20 \\
\hline & Maximum $^{4}$ & 0.38 & 1.44 & 0.09 & 0.07 & 0.07 & 0.15 & 53.30 & 1.29 & 0.02 & 2.56 & 0.22 & 53.30 & 14 \\
\hline & Average $^{4}$ & 0.38 & 0.40 & 0.08 & 0.05 & 0.03 & 0.03 & 1.59 & 0.32 & 0.01 & 0.81 & 0.13 & 0.68 & 2.0 \\
\hline & Median $^{4}$ & 0.38 & 0.21 & 0.08 & 0.05 & 0.02 & 0.02 & 0.07 & 0.08 & 0.01 & 0.50 & 0.11 & 0.07 & 1.4 \\
\hline \multirow[t]{5}{*}{$7(11)$} & Detections $^{2}$ & 1 & 5 & 1 & 4 & 5 & 6 & 11 & 3 & 2 & 10 & 4 & 11 & -- \\
\hline & Minimum $^{4}$ & 0.06 & 0.05 & 0.03 & 0.02 & 0.003 & 0.004 & 0.01 & 0.04 & 0.01 & 0.16 & 0.03 & 0.003 & 0.03 \\
\hline & Maximum $^{4}$ & 0.06 & 2.26 & 0.03 & 0.06 & 0.03 & 0.11 & 2.91 & 0.49 & 0.01 & 2.35 & 0.07 & 2.91 & 7.6 \\
\hline & Average $^{4}$ & 0.06 & 0.60 & 0.03 & 0.04 & 0.01 & 0.02 & 0.16 & 0.20 & 0.01 & 0.60 & 0.05 & 0.23 & 2.1 \\
\hline & Median $^{4}$ & 0.06 & 0.20 & 0.03 & 0.04 & 0.01 & 0.01 & 0.05 & 0.13 & 0.01 & 0.46 & 0.06 & 0.06 & 1.6 \\
\hline \multirow[t]{5}{*}{$8(2)$} & Detections $^{2}$ & 0 & 0 & 0 & 1 & 2 & 1 & 2 & 2 & 0 & 2 & 2 & 2 & -- \\
\hline & Minimum $^{4}$ & -- & -- & -- & 0.04 & 0.02 & 0.09 & 0.02 & 0.02 & -- & 0.12 & 0.02 & 0.015 & -- \\
\hline & Maximum $^{4}$ & -- & -- & -- & 0.04 & 0.02 & 0.09 & 0.08 & 0.62 & -- & 0.46 & 0.30 & 0.62 & -- \\
\hline & Average $^{4}$ & -- & -- & -- & 0.04 & 0.02 & 0.09 & 0.05 & 0.32 & -- & 0.24 & 0.12 & 0.14 & -- \\
\hline & Median $^{4}$ & -- & -- & -- & 0.04 & 0.02 & 0.09 & 0.05 & 0.32 & -- & 0.19 & 0.05 & 0.07 & -- \\
\hline \multirow[t]{5}{*}{$9(12)$} & Detections ${ }^{2}$ & 1 & 3 & 0 & 7 & 2 & 6 & 12 & 5 & 4 & 9 & 6 & 12 & -- \\
\hline & Minimum $^{4}$ & 0.60 & 0.09 & -- & 0.01 & 0.02 & 0.01 & 0.01 & 0.01 & 0.01 & 0.17 & 0.04 & 0.01 & 9.6 \\
\hline & Maximum $^{4}$ & 0.60 & 0.37 & -- & 0.10 & 0.02 & 0.05 & 4.21 & 0.44 & 0.01 & 0.87 & 0.23 & 4.21 & 168 \\
\hline & Average $^{4}$ & 0.60 & 0.24 & -- & 0.05 & 0.02 & 0.02 & 0.21 & 0.15 & 0.01 & 0.41 & 0.11 & 0.17 & 53 \\
\hline & Median $^{4}$ & 0.60 & 0.25 & -- & 0.05 & 0.02 & 0.02 & 0.07 & 0.13 & 0.01 & 0.32 & 0.07 & 0.06 & 29 \\
\hline
\end{tabular}


Table 13. Summary of constituent concentrations by category of total common organic micro-constituents by site in base-flow samples, June 2006 through September 2013.Continued

[ $\mu \mathrm{g} / \mathrm{L}$, micrograms per liter; PAHs, polyaromatic hydrocarbons; OMC, common organic micro-constituents; fts/s, cubic feet per second; --, no data]

\begin{tabular}{|c|c|c|c|c|c|c|c|c|c|c|c|c|c|c|}
\hline $\begin{array}{l}\text { Site number } \\
\text { and number } \\
\text { of samples } \\
\text { (table 2; } \\
\text { fig. 1) }\end{array}$ & Statistic & $\begin{array}{c}\text { Total } \\
\text { antioxidants } \\
(\mu \mathrm{g} / \mathrm{L})\end{array}$ & $\begin{array}{c}\text { Total } \\
\text { detergents } \\
(\mu \mathrm{g} / \mathrm{L})\end{array}$ & $\begin{array}{c}\text { Total } \\
\text { disinfectants } \\
(\mu \mathrm{g} / \mathrm{L})\end{array}$ & $\begin{array}{c}\text { Total } \\
\text { fire } \\
\text { retardants } \\
(\mu \mathrm{g} / \mathrm{L})\end{array}$ & $\begin{array}{c}\text { Total } \\
\text { flavorings } \\
\text { and } \\
\text { fragrances } \\
\text { ( } \mu \mathrm{g} / \mathrm{L})\end{array}$ & $\begin{array}{c}\text { Total } \\
\text { PAHs and } \\
\text { combustion } \\
\text { products } \\
(\mu \mathrm{g} / \mathrm{L})\end{array}$ & $\begin{array}{c}\text { Total } \\
\text { pesticides } \\
(\mu \mathrm{g} / \mathrm{L})\end{array}$ & $\begin{array}{c}\text { Total } \\
\text { plastics } \\
(\mu \mathrm{g} / \mathrm{L})\end{array}$ & $\begin{array}{c}\text { Total } \\
\text { solvents } \\
\text { ( } \mu \mathrm{g} / \mathrm{L} \text { ) }\end{array}$ & $\begin{array}{c}\text { Total } \\
\text { sterols and } \\
\text { stanols } \\
(\mu \mathrm{g} / \mathrm{L})\end{array}$ & $\begin{array}{c}\text { Total } \\
\text { stimulants } \\
(\mu \mathrm{g} / \mathrm{L})\end{array}$ & $\begin{array}{c}\text { Total } \\
\text { OMC } \\
(\mu \mathrm{g} / \mathrm{L})\end{array}$ & $\begin{array}{c}\text { Streamflow } 1 \\
\quad\left(\mathrm{ft}^{3} / \mathbf{s}\right)\end{array}$ \\
\hline \multirow[t]{5}{*}{$11(1)$} & Detections $^{2}$ & 0 & 1 & 0 & 0 & 0 & 1 & 1 & 0 & 0 & 0 & 0 & 1 & -- \\
\hline & Minimum $^{4}$ & -- & 0.10 & -- & -- & -- & 0.01 & 0.03 & -- & -- & -- & -- & 0.01 & 0.50 \\
\hline & Maximum $^{4}$ & -- & 0.10 & -- & -- & -- & 0.01 & 0.11 & -- & -- & -- & -- & 0.11 & 0.70 \\
\hline & Average $^{4}$ & -- & 0.10 & -- & -- & -- & 0.01 & 0.07 & -- & -- & -- & -- & 0.06 & 0.60 \\
\hline & Median $^{4}$ & -- & 0.10 & -- & -- & -- & 0.01 & 0.07 & -- & -- & -- & -- & 0.07 & 0.60 \\
\hline
\end{tabular}

${ }^{1}$ Streamflow calculated from an established stage-discharge relation for the site at the time of sampling.

${ }^{2}$ Number of samples with one or more detections of OMC greater than the method detection level. OMC categories may have more than one OMC detected per sample

${ }^{3}$ Total number of individual OMCs detected. Detections of individual OMCs are presented in the appendixes.

${ }^{4}$ Minimum, maximum, average, and median values are calculated from data that may contain estimated values. Values less than the minimum reporting level were not included in the statistical analysis. 
Table 14. Summary of constituent concentrations by category of total common organic micro-constituents by site in stormflow samples, June 2005 through September 2013.

[ $\mu \mathrm{g} / \mathrm{L}$, micrograms per liter; PAHs, polyaromatic hydrocarbons; OMC, common organic micro-constituents; $\mathrm{ft}^{3} / \mathrm{s}$, cubic feet per second; --, no data]

\begin{tabular}{|c|c|c|c|c|c|c|c|c|c|c|c|c|c|c|}
\hline $\begin{array}{l}\text { Site number } \\
\text { and number } \\
\text { of samples } \\
\text { (table 2; } \\
\text { fig. 1) }\end{array}$ & Statistic & $\begin{array}{c}\text { Total } \\
\text { antioxidants } \\
(\mu \mathrm{g} / \mathrm{L})\end{array}$ & $\begin{array}{c}\text { Total } \\
\text { detergents } \\
(\mu \mathrm{g} / \mathrm{L})\end{array}$ & $\begin{array}{c}\text { Total } \\
\text { disinfectants } \\
(\mu \mathrm{g} / \mathrm{L})\end{array}$ & $\begin{array}{c}\text { Total } \\
\text { fire } \\
\text { retardants } \\
(\mu \mathrm{g} / \mathrm{L})\end{array}$ & $\begin{array}{c}\text { Total } \\
\text { flavorings } \\
\text { and } \\
\text { fragrances } \\
(\mu \mathrm{g} / \mathrm{L})\end{array}$ & $\begin{array}{c}\text { Total } \\
\text { PAHs and } \\
\text { combustion } \\
\text { products } \\
(\mu \mathrm{g} / \mathrm{L})\end{array}$ & $\begin{array}{c}\text { Total } \\
\text { pesticides } \\
(\mu \mathrm{g} / \mathrm{L})\end{array}$ & $\begin{array}{c}\text { Total } \\
\text { plastics } \\
(\mu \mathrm{g} / \mathrm{L})\end{array}$ & $\begin{array}{c}\text { Total } \\
\text { solvents } \\
\text { ( } \mu \mathrm{g} / \mathrm{L})\end{array}$ & $\begin{array}{l}\text { Total } \\
\text { sterols and } \\
\text { stanols } \\
(\mu \mathrm{g} / \mathrm{L})\end{array}$ & $\begin{array}{c}\text { Total } \\
\text { stimulants } \\
(\mu \mathrm{g} / \mathrm{L})\end{array}$ & $\begin{array}{l}\text { Total } \\
\text { OMC } \\
(\mu \mathrm{g} / \mathrm{L})\end{array}$ & $\begin{array}{l}\text { Streamflow } 1 \\
\quad\left(\mathrm{ft}^{3} / \mathbf{s}\right)\end{array}$ \\
\hline \multirow[t]{6}{*}{ All (130) } & Detections $^{2}$ & 45 & 92 & 47 & 101 & 79 & 126 & 130 & 123 & 59 & 117 & 122 & 130 & -- \\
\hline & $\begin{array}{l}\text { Total individual constituents } \\
\text { detected }^{3}\end{array}$ & 45 & 187 & 53 & 177 & 165 & 795 & 981 & 352 & 62 & 271 & 147 & 3235 & -- \\
\hline & Minimum $^{4}$ & 0.08 & 0.02 & 0.02 & 0.02 & 0.003 & 0.004 & 0.002 & 0.01 & 0.01 & 0.06 & 0.03 & 0.002 & 3.10 \\
\hline & Maximum $^{4}$ & 1.10 & 3.27 & 0.54 & 2.07 & 1.10 & 4.68 & 20.40 & 6.21 & 0.13 & 26.40 & 3.32 & 26.40 & 8,030 \\
\hline & Average $^{4}$ & 0.28 & 0.51 & 0.12 & 0.09 & 0.12 & 0.20 & 0.37 & 0.28 & 0.03 & 1.26 & 0.26 & 0.36 & 434 \\
\hline & Median $^{4}$ & 0.22 & 0.33 & 0.09 & 0.07 & 0.07 & 0.07 & 0.13 & 0.16 & 0.02 & 0.78 & 0.17 & 0.13 & 152 \\
\hline \multirow[t]{5}{*}{$1(24)$} & Detections $^{2}$ & 14 & 21 & 13 & 20 & 21 & 24 & 24 & 23 & 14 & 24 & 22 & 24 & -- \\
\hline & Minimum $^{4}$ & 0.13 & 0.04 & 0.04 & 0.02 & 0.01 & 0.01 & 0.01 & 0.01 & 0.01 & 0.06 & 0.04 & 0.01 & 20 \\
\hline & Maximum $^{4}$ & 1.10 & 3.27 & 0.50 & 0.19 & 1.10 & 4.62 & 19.00 & 6.21 & 0.13 & 13.00 & 3.32 & 19.00 & 644 \\
\hline & Average $^{4}$ & 0.36 & 0.71 & 0.14 & 0.09 & 0.15 & 0.30 & 0.59 & 0.35 & 0.03 & 1.99 & 0.61 & 0.54 & 133 \\
\hline & Median $^{4}$ & 0.28 & 0.50 & 0.09 & 0.08 & 0.09 & 0.10 & 0.15 & 0.17 & 0.03 & 1.16 & 0.26 & 0.16 & 77 \\
\hline \multirow[t]{5}{*}{$2(6)$} & Detections $^{2}$ & 2 & 3 & 3 & 5 & 5 & 6 & 6 & 6 & 4 & 6 & 6 & 6 & -- \\
\hline & Minimum $^{4}$ & 0.17 & 0.04 & 0.04 & 0.02 & 0.01 & 0.01 & 0.02 & 0.02 & 0.01 & 0.19 & 0.04 & 0.01 & 104 \\
\hline & Maximum $^{4}$ & 0.19 & 1.05 & 0.09 & 0.34 & 0.26 & 0.36 & 0.56 & 2.52 & 0.04 & 1.34 & 0.20 & 2.52 & 2,750 \\
\hline & Average $^{4}$ & 0.18 & 0.30 & 0.07 & 0.08 & 0.09 & 0.10 & 0.13 & 0.38 & 0.02 & 0.61 & 0.10 & 0.20 & 594 \\
\hline & Median $^{4}$ & 0.18 & 0.18 & 0.08 & 0.05 & 0.06 & 0.08 & 0.11 & 0.14 & 0.02 & 0.56 & 0.10 & 0.10 & 162 \\
\hline \multirow[t]{5}{*}{$3(11)$} & Detections $^{2}$ & 7 & 7 & 3 & 9 & 6 & 11 & 11 & 11 & 5 & 11 & 11 & 11 & -- \\
\hline & Minimum $^{4}$ & 0.08 & 0.03 & 0.04 & 0.02 & 0.02 & 0.004 & 0.01 & 0.01 & 0.01 & 0.06 & 0.03 & 0.004 & 31 \\
\hline & Maximum $^{4}$ & 0.30 & 1.17 & 0.10 & 0.11 & 0.04 & 0.31 & 0.49 & 0.85 & 0.03 & 4.27 & 0.42 & 4.27 & 338 \\
\hline & Average $^{4}$ & 0.20 & 0.33 & 0.07 & 0.06 & 0.03 & 0.05 & 0.12 & 0.23 & 0.02 & 1.22 & 0.19 & 0.24 & 126 \\
\hline & Median $^{4}$ & 0.22 & 0.28 & 0.05 & 0.05 & 0.03 & 0.02 & 0.09 & 0.15 & 0.02 & 1.06 & 0.19 & 0.08 & 125 \\
\hline
\end{tabular}


Table 14. Summary of constituent concentrations by category of total common organic micro-constituents by site in stormflow samples, June 2005 through September 2013.Continued

[ $\mu \mathrm{g} / \mathrm{L}$, micrograms per liter; PAHs, polyaromatic hydrocarbons; OMC, common organic micro-constituents; $\mathrm{ft}^{3} / \mathrm{s}$, cubic feet per second; --, no data]

\begin{tabular}{|c|c|c|c|c|c|c|c|c|c|c|c|c|c|c|}
\hline $\begin{array}{l}\text { Site number } \\
\text { and number } \\
\text { of samples } \\
\text { (table 2; } \\
\text { fig. 1) }\end{array}$ & Statistic & $\begin{array}{c}\text { Total } \\
\text { antioxidants } \\
(\mu \mathrm{g} / \mathrm{L})\end{array}$ & $\begin{array}{c}\text { Total } \\
\text { detergents } \\
(\mu \mathrm{g} / \mathrm{L})\end{array}$ & $\begin{array}{c}\text { Total } \\
\text { disinfectants } \\
(\mu \mathrm{g} / \mathrm{L})\end{array}$ & $\begin{array}{l}\text { Total } \\
\text { fire } \\
\text { retardants } \\
(\mu \mathrm{g} / \mathrm{L})\end{array}$ & $\begin{array}{c}\text { Total } \\
\text { flavorings } \\
\text { and } \\
\text { fragrances } \\
(\mu \mathrm{g} / \mathrm{L})\end{array}$ & $\begin{array}{c}\text { Total } \\
\text { PAHs and } \\
\text { combustion } \\
\text { products } \\
\text { ( } \mu \mathrm{g} / \mathrm{L})\end{array}$ & $\begin{array}{c}\text { Total } \\
\text { pesticides } \\
(\mu \mathrm{g} / \mathrm{L})\end{array}$ & $\begin{array}{c}\text { Total } \\
\text { plastics } \\
(\mu \mathrm{g} / \mathrm{L})\end{array}$ & $\begin{array}{c}\text { Total } \\
\text { solvents } \\
\text { ( } \mu \mathrm{g} / \mathrm{L})\end{array}$ & $\begin{array}{l}\text { Total } \\
\text { sterols and } \\
\text { stanols } \\
(\mu \mathrm{g} / \mathrm{L})\end{array}$ & $\begin{array}{c}\text { Total } \\
\text { stimulants } \\
(\mu \mathrm{g} / \mathrm{L})\end{array}$ & $\begin{array}{l}\text { Total } \\
\text { OMC } \\
\text { ( } \mu \mathrm{g} / \mathrm{L})\end{array}$ & $\begin{array}{c}\text { Streamflow }{ }^{1} \\
\left(\mathrm{ft}^{3} / \mathbf{s}\right)\end{array}$ \\
\hline \multirow[t]{5}{*}{$4(5)$} & Detections $^{2}$ & 0 & 3 & 2 & 2 & 2 & 3 & 5 & 3 & 3 & 5 & 3 & 5 & -- \\
\hline & Minimum $^{4}$ & -- & 0.04 & 0.03 & 0.03 & 0.01 & 0.01 & 0.02 & 0.03 & 0.01 & 0.28 & 0.03 & 0.01 & 11 \\
\hline & Maximum $^{4}$ & -- & 0.87 & 0.05 & 0.07 & 0.03 & 0.02 & 0.76 & 0.55 & 0.02 & 1.87 & 0.05 & 1.87 & 278 \\
\hline & Average $^{4}$ & -- & 0.34 & 0.04 & 0.05 & 0.02 & 0.01 & 0.14 & 0.20 & 0.01 & 0.71 & 0.03 & 0.20 & 74 \\
\hline & Median $^{4}$ & -- & 0.23 & 0.04 & 0.05 & 0.02 & 0.01 & 0.07 & 0.13 & 0.02 & 0.62 & 0.03 & 0.05 & 30 \\
\hline \multirow[t]{5}{*}{$5(19)$} & Detections $^{2}$ & 2 & 14 & 4 & 13 & 11 & 18 & 19 & 17 & 5 & 15 & 18 & 19 & -- \\
\hline & Minimum $^{4}$ & 0.20 & 0.04 & 0.05 & 0.04 & 0.004 & 0.004 & 0.01 & 0.01 & 0.01 & 0.20 & 0.06 & 0.004 & 72 \\
\hline & Maximum $^{4}$ & 0.23 & 1.74 & 0.48 & 0.25 & 0.33 & 1.03 & 2.60 & 0.75 & 0.03 & 1.70 & 0.44 & 2.60 & 5,500 \\
\hline & Average $^{4}$ & 0.21 & 0.46 & 0.16 & 0.08 & 0.09 & 0.13 & 0.31 & 0.22 & 0.02 & 0.78 & 0.19 & 0.26 & 702 \\
\hline & Median $^{4}$ & 0.21 & 0.32 & 0.06 & 0.08 & 0.06 & 0.07 & 0.14 & 0.15 & 0.02 & 0.75 & 0.18 & 0.13 & 308 \\
\hline \multirow[t]{5}{*}{$6(16)$} & Detections $^{2}$ & 5 & 12 & 6 & 14 & 10 & 16 & 16 & 16 & 7 & 14 & 15 & 16 & -- \\
\hline & Minimum $^{4}$ & 0.21 & 0.02 & 0.04 & 0.02 & 0.01 & 0.004 & 0.01 & 0.01 & 0.01 & 0.15 & 0.04 & 0.004 & 14.00 \\
\hline & Maximum $^{4}$ & 0.48 & 1.44 & 0.54 & 0.32 & 0.58 & 4.65 & 20.40 & 1.90 & 0.04 & 3.44 & 0.58 & 20.40 & 1,000 \\
\hline & Average $^{4}$ & 0.31 & 0.46 & 0.19 & 0.11 & 0.09 & 0.37 & 0.63 & 0.36 & 0.02 & 0.98 & 0.25 & 0.44 & 172 \\
\hline & Median $^{4}$ & 0.24 & 0.34 & 0.14 & 0.08 & 0.04 & 0.14 & 0.16 & 0.20 & 0.03 & 0.84 & 0.20 & 0.16 & 60.50 \\
\hline \multirow[t]{5}{*}{$7(24)$} & Detections $^{2}$ & 10 & 17 & 9 & 18 & 14 & 24 & 24 & 23 & 13 & 21 & 23 & 24 & -- \\
\hline & Minimum $^{4}$ & 0.16 & 0.04 & 0.02 & 0.02 & 0.003 & 0.01 & 0.002 & 0.01 & 0.01 & 0.14 & 0.04 & 0.002 & 3.10 \\
\hline & Maximum $^{4}$ & 0.81 & 1.95 & 0.28 & 2.07 & 0.50 & 1.87 & 6.20 & 2.20 & 0.05 & 26.40 & 0.79 & 26.40 & 770 \\
\hline & Average $^{4}$ & 0.33 & 0.58 & 0.11 & 0.13 & 0.13 & 0.18 & 0.38 & 0.27 & 0.03 & 1.61 & 0.24 & 0.38 & 162 \\
\hline & Median $^{4}$ & 0.23 & 0.38 & 0.09 & 0.07 & 0.09 & 0.09 & 0.15 & 0.20 & 0.03 & 0.78 & 0.19 & 0.15 & 83 \\
\hline \multirow[t]{5}{*}{$8(2)$} & Detections $^{2}$ & 1 & 1 & 0 & 1 & 1 & 2 & 2 & 1 & 0 & 2 & 2 & 2 & -- \\
\hline & Minimum $^{4}$ & 0.09 & 0.19 & -- & 0.02 & 0.02 & 0.01 & 0.01 & 0.01 & -- & 0.08 & 0.03 & 0.01 & -- \\
\hline & Maximum $^{4}$ & 0.09 & 0.19 & -- & 0.11 & 0.02 & 0.04 & 1.19 & 1.48 & -- & 0.54 & 0.11 & 1.48 & -- \\
\hline & Average $^{4}$ & 0.09 & 0.19 & -- & 0.07 & 0.02 & 0.02 & 0.17 & 0.41 & -- & 0.29 & 0.07 & 0.17 & -- \\
\hline & Median $^{4}$ & 0.09 & 0.19 & -- & 0.07 & 0.02 & 0.01 & 0.06 & 0.03 & -- & 0.20 & 0.07 & 0.05 & -- \\
\hline
\end{tabular}


Table 14. Summary of constituent concentrations by category of total common organic micro-constituents by site in stormflow samples, June 2005 through September $2013 .-$ Continued

[ $\mu \mathrm{g} / \mathrm{L}$, micrograms per liter; PAHs, polyaromatic hydrocarbons; OMC, common organic micro-constituents; $\mathrm{ft}^{3} / \mathrm{s}$, cubic feet per second; --, no data]

\begin{tabular}{|c|c|c|c|c|c|c|c|c|c|c|c|c|c|c|}
\hline $\begin{array}{l}\text { Site number } \\
\text { and number } \\
\text { of samples } \\
\text { (table 2; } \\
\text { fig. 1) }\end{array}$ & Statistic & $\begin{array}{c}\text { Total } \\
\text { antioxidants } \\
(\mu \mathrm{g} / \mathrm{L})\end{array}$ & $\begin{array}{c}\text { Total } \\
\text { detergents } \\
(\mu \mathrm{g} / \mathrm{L})\end{array}$ & $\begin{array}{c}\text { Total } \\
\text { disinfectants } \\
(\mu \mathrm{g} / \mathrm{L})\end{array}$ & $\begin{array}{l}\text { Total } \\
\text { fire } \\
\text { retardants } \\
(\mu \mathrm{g} / \mathrm{L})\end{array}$ & $\begin{array}{c}\text { Total } \\
\text { flavorings } \\
\text { and } \\
\text { fragrances } \\
(\mu \mathrm{g} / \mathrm{L}) \\
\end{array}$ & $\begin{array}{c}\text { Total } \\
\text { PAHs and } \\
\text { combustion } \\
\text { products } \\
(\mu \mathrm{g} / \mathrm{L})\end{array}$ & $\begin{array}{c}\text { Total } \\
\text { pesticides } \\
(\mu \mathrm{g} / \mathrm{L})\end{array}$ & $\begin{array}{c}\text { Total } \\
\text { plastics } \\
\text { ( } \mu \mathrm{g} / \mathrm{L})\end{array}$ & $\begin{array}{c}\text { Total } \\
\text { solvents } \\
\text { ( } \mu \mathrm{g} / \mathrm{L})\end{array}$ & $\begin{array}{l}\text { Total } \\
\text { sterols and } \\
\text { stanols } \\
(\mu \mathrm{g} / \mathrm{L})\end{array}$ & $\begin{array}{c}\text { Total } \\
\text { stimulants } \\
(\mu \mathrm{g} / \mathrm{L})\end{array}$ & $\begin{array}{l}\text { Total } \\
\text { OMC } \\
(\mu \mathrm{g} / \mathrm{L})\end{array}$ & $\begin{array}{c}\text { Streamflow } \\
\left(\mathrm{ft}^{3} / \mathbf{s}\right)\end{array}$ \\
\hline \multirow[t]{5}{*}{$9(23)$} & Detections $^{2}$ & 4 & 14 & 7 & 19 & 9 & 22 & 23 & 23 & 8 & 19 & 22 & 23 & -- \\
\hline & Minimum $^{4}$ & 0.09 & 0.03 & 0.03 & 0.02 & 0.01 & 0.01 & 0.01 & 0.01 & 0.01 & 0.11 & 0.03 & 0.01 & 134 \\
\hline & Maximum $^{4}$ & 0.14 & 1.31 & 0.19 & 0.22 & 0.45 & 1.39 & 8.10 & 0.54 & 0.05 & 1.30 & 0.42 & 8.10 & 8,030 \\
\hline & Average $^{4}$ & 0.12 & 0.32 & 0.09 & 0.07 & 0.14 & 0.14 & 0.28 & 0.17 & 0.02 & 0.56 & 0.12 & 0.22 & 1,163 \\
\hline & Median ${ }^{4}$ & 0.12 & 0.26 & 0.07 & 0.06 & 0.12 & 0.06 & 0.11 & 0.15 & 0.02 & 0.53 & 0.11 & 0.11 & 520 \\
\hline
\end{tabular}

${ }^{1}$ Average streamflow for the sampled storm interval.

${ }^{2}$ Number of samples with one or more detections of OMC greater than the method detection level. OMC categories may have more than one OMC detected per sample.

${ }^{3}$ Total number of individual OMCs detected. Detections of individual OMCs are presented in the appendixes.

${ }^{4}$ Minimum, maximum, average, and median values are calculated from data that may contain estimated values. Values less than the minimum reporting level were not included in the statistical analysis. 
Table 15. Pesticide constituents analyzed in streambed sediment and surface-water samples.

[DDT, dichlorodiphenyltrichloroethane; HCH, hexachlorocyclohexane; DDD, dichlorodiphenyl dichloroethane; DDE, dichlorodiphenyldichloroethylene]

\begin{tabular}{|c|c|c|c|}
\hline \multicolumn{4}{|c|}{ Pesticides analyzed in streambed sediment samples (dry weight, in micrograms per kilogram) } \\
\hline Aldrin & Heptachlor epoxide & $p, p^{\prime}$-DDT & Aroclor 1260 \\
\hline$\alpha$-Endosulfan & Heptachlor & $p, p^{\prime}$-Methor & \\
\hline$\beta-\mathrm{HCH}$ & Lindane & trans-Chlor & \\
\hline cis-Chlordane & Mirex & trans-Nona & \\
\hline \multicolumn{4}{|c|}{ Pesticides analyzed in unfiltered surface-water samples (in micrograms per liter) } \\
\hline Aldrin & $\delta$-HCH & Lindane & Aroclor 1221 \\
\hline$\alpha$-Endosulfan & Dieldrin & $p, p$-DDD & Aroclor 1232 \\
\hline$\alpha-\mathrm{HCH}$ & Endosulfan sulfate & $p, p$ '-DDE & Aroclor 1248 \\
\hline cis-Chlordane & Heptachlor & Aroclor 101 & \\
\hline
\end{tabular}

E. coli during WY 2006, and site 9 had the highest flowweighted concentration during WY 2007. Site 1 had the highest flow-weighted concentrations in WYs 2008, 2009, and 2011, and site 2 had the highest flow-weighted concentrations in WYs 2010, 2012, and 2013. The lowest estimated annual flow-weighted concentrations of $E$. Coli were measured at site 5 in WYs 2006 and 2008, site 6 in WY 2007, and site 3 in WYs 2009 and 2010. Site 4 had the lowest estimated annual flow-weighted concentrations of $E$. Coli of all the sites for all three years of collection there (WYs 2011 to 2013). The estimated annual flow-weighted concentrations of $E$. Coli measured on the Little Blue River at site 2 in WY 2011, site 5 in WY 2006, and at site 9 during WYs 2006 and 2011 were less than one-half of the lowest concentration measured in any other year at those sites.

The MST results for WY 2007 collected at two Little Blue River sites (sites 5 and 9) were combined to compare with the smaller Independence streams. Samples from sites 6 and 7, and the Little Blue River sites (5 and 9) were analyzed for host sources of $E$. coli bacteria during one base-flow and stormflow samplings in August and October 2007 (table 17). Additional stormflow samples were collected at sites 5 and 9 in May 2007 and at site 1 in October 2007. Site 6 had the highest percentage of human sources of $E$. coli ( 26.7 percent) for base-flow samples. Percentages of $E$. coli from human sources in stormflow samples in the three smaller streams (sites 1,6 , and 7) were higher (20.0 to 27.8 percent) than for sites 5 and 9 .

E. coli and MST markers were analyzed using libraryindependent methods in 119 base-flow, 89 stormflow, and 4 snowmelt samples collected from June 2008 through September 2013. MST samples were collected at sites 1 through 9 and 11. In addition, 48 fecal source samples were collected between September 2011 and May 2013 from human, ruminant, dog, and several domestic and wild animal sources. Twelve sewage influent samples also were collected from September 2011 through May 2013 (table 18).

E. coli was detected in 112 of 119 base-flow samples (E. coli was not analyzed in 5 samples), all 89 stormflow samples, and all 4 snowmelt samples for which MST markers also were analyzed (table 19, http://pubs.usgs.gov/ds/0915/ downloads/ds915_table19.xlsx). AllBac, a general marker used to indicate the presence of fecal material in bacterial sources, was detected in all samples. B.theta, a human marker, was detected and quantifiable in 4 base-flow and 9 stormflow samples out of 45 analyzed. HF183, a human marker, was detected in 60 of 119 samples and quantifiable in 37 samples; BacCan, a canine marker, was detected in 22 of 119 samples and quantifiable in 12 samples; and BoBac, a ruminant marker, was detected in 41 of 71 samples and quantifiable in 37 samples. For stormflow samples, HF183 was detected in 73 of 89 samples and quantifiable in 57 samples; BacCan was detected in 57 of 89 samples and quantifiable in 39 samples; and BoBac was detected in 41 of 46 samples and quantifiable in 31 samples. HF183 was detected, but not quantified, in two of four snowmelt samples; BacCan was detected, but not quantified, in two samples; and BoBac was detected and quantified in all four snowmelt samples.

During the recreation season, about 45 percent of baseflow samples and about 98 percent of stormflow samples exceeded the Missouri standard (Missouri Department of Natural Resources, 2014b) for whole-body contact recreation for $E$. coli of 206 colony forming units per 100 milliliters (CFU/100 mL) (table 19). E. coli and host-associated genetic markers (human, canine, and ruminant) were detected more frequently and at higher concentrations during stormflow than 
Table 16. Summary of selected pesticides detected in streambed sediment samples during base flow at all Independence sites, July 2010 through July 2013.

$\left[\mu \mathrm{g} / \mathrm{kg}\right.$, micrograms per kilogram; $p, p^{\prime}$-DDD, $p, p^{\prime}$-dichlorodiphenyl dichloroethane; $p, p^{\prime}$-DDE, $p, p^{\prime}$ '-dichlorodiphenyldichloroethylene; $p, p^{\prime}$-DDT, $p, p^{\prime}$-dichlorodiphenyltrichloroethane; all Independence sites from table 2, fig. 1]

\begin{tabular}{|c|c|c|c|c|c|c|c|c|c|c|c|}
\hline Statistic & $\begin{array}{c}\text { cis- } \\
\text { Chlordane } \\
(\mu \mathrm{g} / \mathrm{kg})\end{array}$ & $\begin{array}{l}\text { Dieldrin } \\
\text { ( } \mu \mathrm{g} / \mathrm{kg})\end{array}$ & $\begin{array}{l}\text { Heptachlor } \\
\text { epoxide } \\
(\mu \mathrm{g} / \mathrm{kg})\end{array}$ & $\begin{array}{c}p, p^{\prime}-\text { DDD } \\
(\mu \mathrm{g} / \mathrm{kg})\end{array}$ & $\begin{array}{c}p, p^{\prime}-\mathrm{DDE} \\
(\mu \mathrm{g} / \mathrm{kg})\end{array}$ & $\begin{array}{c}p, p^{\prime}-\mathrm{DDT} \\
(\mu \mathrm{g} / \mathrm{kg})\end{array}$ & $\begin{array}{c}\text { trans- } \\
\text { Chlordane } \\
(\mu \mathrm{g} / \mathrm{kg})\end{array}$ & $\begin{array}{c}\text { trans- } \\
\text { Nonachlor } \\
(\mu \mathrm{g} / \mathrm{kg})\end{array}$ & $\begin{array}{c}\text { Aroclor } 1016 \\
\text { plus } \\
\text { Aroclor } 1242 \\
(\mu \mathrm{g} / \mathrm{kg})\end{array}$ & $\begin{array}{c}\text { Aroclor } 1254 \\
(\mu \mathrm{g} / \mathrm{kg})\end{array}$ & $\begin{array}{c}\text { Aroclor } 1260 \\
(\mu \mathrm{g} / \mathrm{kg})\end{array}$ \\
\hline Samples & 14 & 14 & 14 & 14 & 14 & 14 & 14 & 14 & 14 & 14 & 14 \\
\hline Detections $^{1}$ & 6 & 7 & 1 & 4 & 4 & 4 & 10 & 8 & 4 & 6 & 6 \\
\hline Minimum $^{2}$ & 0.80 & 0.270 & 4.20 & 2 & 1.00 & 0.560 & 0.280 & 0.430 & 4.700 & 5.400 & 5.00 \\
\hline Maximum $^{2}$ & 17.00 & 1.900 & 4.20 & 8 & 3.70 & 14.000 & 9.800 & 7.100 & 76.000 & 34.000 & 16.00 \\
\hline Average $^{2}$ & 6.00 & 1.057 & 4.20 & 4 & 1.80 & 4.478 & 2.984 & 2.711 & 24.175 & 13.100 & 10.70 \\
\hline Median $^{2}$ & 4.10 & 0.83 & 4.20 & 3.60 & 1.40 & 2.600 & 0.640 & 0.910 & 8.700 & 10.000 & 9.50 \\
\hline
\end{tabular}

${ }^{1}$ Number of samples with one or more detections of selected pesticide constituents.

${ }^{2}$ Minimum, maximum, average, and median values are calculated from data that may contain estimated values or less than the minimum reporting level. 
in base-flow conditions. Most of the estimated E. coli loads occurred during stormflow (table 11).

Median SSC for base-flow samples collected at sites 1 through 9 and 11 from WYs 2006 through 2013 ranged from $13 \mathrm{mg} / \mathrm{L}$ at site 2 to $63 \mathrm{mg} / \mathrm{L}$ at site 6 (table 9). The Little Blue River sites (sites 2, 5, and 9) had lower SSC concentrations than most of the smaller Independence streams (sites 1, 6, 7, 8, and 11) except for sites 3 and 4 located just downstream from lake spillways.

Median SSC measured at sites with multiple stormflow samples (sites 1 through 9) for WYs 2005 through 2013 ranged from $66 \mathrm{mg} / \mathrm{L}$ at site 3 to $1,130 \mathrm{mg} / \mathrm{L}$ at site 7 (table 10). Although site 11 had a higher measured SSC than site 7 , site 11 was not used for comparison because only one stormflow sample was collected there during the study period. The Little Blue River sites 2 and 9 had concentrations in the mid-range compared to those of the smaller streams draining Independence (sites 1, 3, 6, and 7). Site 5 had a median SSC of $211 \mathrm{mg} / \mathrm{L}$ but was discontinued in October 2009. Sites 1, 3, 4, and 8 had lower SSCs than sites 2 and 9, and sites 6 and 7 had higher median SSCs. The median SSC for site $2(732 \mathrm{mg} / \mathrm{L})$ was higher than downstream at site $9(643 \mathrm{mg} / \mathrm{L})$.

Estimated SSC annual loads ranged from $240 \mathrm{Mg}$ at site 3 in WY 2011 to $808,000 \mathrm{Mg}$ at site 9 in WY 2007 (table 11). Site 9 also had the highest annual daily average streamflow and estimated annual load of SSC during all years in the study period. The SSC estimated annual flow-weighted concentrations varied from $35 \mathrm{mg} / \mathrm{L}$ at site 4 in WY 2013 to 4,479 $\mathrm{mg} / \mathrm{L}$ at site 9 in WY 2007. The highest estimated annual flow-weighted concentrations were at site 7 in WYs 2006 and 2011, and site 9 in WYs 2007 through 2010 and 2013. Lee's Summit Road (site 2) had the highest estimated SSC annual flow-weighted concentration in WY 2012. Most sites measured during WY 2007, except for site 1, had the highest estimated annual flow-weighted SSC that WY among all WYs of measurement. Site 1 had the highest estimated annual flow-weighted SSC in WY 2008, sites 2 and 3 in WY 2010, and site 4 in WY 2012. Most sites measured during
WY 2006, except for site 1, had the lowest estimated annual flow-weighted SSC that WY among all WYs of measurement. Site 1 had the lowest estimated annual flow-weighted SSC in WY 2012, sites 2 and 3 in WY 2011, and site 4 in WY 2013.

\section{Dry-Weather Screening}

Dry-weather screening was done by the USGS and Independence WPC Department personnel during WYs 2006 through 2013 in most basins within Independence except Fire Prairie Creek (table 2; fig. 2). Any measureable inflow, discharge, or tributary flow to the selected stream was sampled. Two basins, Rock Creek (table 20; fig. 13) and Spring Branch Creek, were sampled four times from WYs 2006 to 2013.

Adair Creek was sampled three times, and all remaining basins (Crackerneck, Mill, Sugar, Bundschu, Burr Oak, and West Fire Prairie Creeks, and East Fork Little Blue and Little Blue Rivers) were sampled one or two times. A total of 1,052 samples (table 20) were collected from area stream basins for analysis of total chlorine, total dissolved copper, phenols, and anionic surfactants. Total chlorine was analyzed in 1,049 samples; phenols in 1,035 samples; and anionic surfactants in 1,048 samples (table 20; fig. 14). Total dissolved copper was discontinued as an analyte after WY 2010 and was analyzed in 803 samples; however, 39 sample results were not included in any statistical analysis because the presence of total dissolved copper was detected above the MDL but the samples had no visual color.

Sources for most dry-weather screening analyte detections that exceeded a guideline or standard could not be determined, and when determined were considered to be de minimus (minimal) from a source such as car washing or lawn watering. Eight detections were determined to have a source such as a straight pipe discharge or broken water/septic line and corrective action was taken by Independence WPC. About 207 samples (19.7 percent) were at or above a defined standard or guideline for each constituent. A total of

Table 17. Presumptive host sources of Escherichia coli in samples collected May through October 2007.

[Christensen and others, 2010. E. coli, Escherichia coli; B, base flow; S, stormflow]

\begin{tabular}{|c|c|c|c|c|c|c|}
\hline \multirow{2}{*}{$\begin{array}{l}\text { Site number } \\
\text { (table 2; fig. 1) }\end{array}$} & \multirow{2}{*}{ Date } & \multirow{2}{*}{$\begin{array}{l}\text { Streamflow } \\
\text { condition }\end{array}$} & \multirow{2}{*}{$\begin{array}{c}\text { E. coli } \\
\text { (number of colonies) }\end{array}$} & \multicolumn{3}{|c|}{ Presumptive host source (percentage of total colonies) } \\
\hline & & & & Dog and goose & Human & Unknown \\
\hline \multicolumn{7}{|c|}{ Base-flow samples } \\
\hline 6 & $8 / 7 / 2007$ & $\mathrm{~B}$ & 190 & 40.0 & 26.7 & 33.0 \\
\hline 7 & $8 / 7 / 2007$ & $\mathrm{~B}$ & 470 & 25.0 & 0.0 & 75.0 \\
\hline 5 and 9 & $8 / 7 / 2007$ & $\mathrm{~B}$ & 140 & 69.2 & 15.4 & 15.4 \\
\hline \multicolumn{7}{|c|}{ Stormflow samples } \\
\hline 5 and 9 & $5 / 8 / 2007$ & $\mathrm{~S}$ & 77,000 & 50.7 & 12.0 & 37.3 \\
\hline 1 & $10 / 18 / 2007$ & S & 35,800 & 50.0 & 20.0 & 30.0 \\
\hline 6 & $10 / 18 / 2007$ & $\mathrm{~S}$ & 18,000 & 33.3 & 27.8 & 38.9 \\
\hline 7 & $10 / 18 / 2007$ & $\mathrm{~S}$ & 21,000 & 50.0 & 22.2 & 28.0 \\
\hline 5 and 9 & $10 / 18 / 2007$ & $\mathrm{~S}$ & 40,000 & 38.2 & 14.5 & 47.3 \\
\hline
\end{tabular}


73 samples (6.9 percent) were over the State reportable/compliance level for total chlorine of $0.13 \mathrm{mg} / \mathrm{L}$ (table 20; Missouri Department of Natural Resources, 2006), which was used as a guideline in this report; nearly one-half (35 samples) of these samples were detected in the Spring Branch Creek basin. No Federal or State standard has been determined for dissolved copper in unfiltered (total) samples. There were, however, 226 detections ( 21.5 percent) that were higher than the EDL for total dissolved copper. For purposes of comparison in this report, the concentrations of phenols were considered to be equivalent to the concentration of the individual compound phenol, for which there is a Missouri State AQL chronic standard of $0.100 \mathrm{mg} / \mathrm{L}$ (Missouri Department of Natural Resources, 2014b). The Missouri State AQL chronic standard for phenol was recently updated (January 2014) to a standard of 0.256 (Missouri Department of Natural Resources, 2014b), but for purposes of this report the previous standard of $0.100 \mathrm{mg} / \mathrm{L}$ will be used. Only one sample (less than 1 percent) was measured at a level greater than the Missouri AQL of $0.100 \mathrm{mg} / \mathrm{L}$, from the Rock Creek basin in WY 2006. The most commonly detected surfactant (detergent) in base-flow samples was nonylphenol, a nonionic surfactant (appendix 1). There were 133 samples (12.6 percent) that were detected above the EPA freshwater standard for acute exposure for aquatic communities to nonylphenol of $0.028 \mathrm{mg} / \mathrm{L}$, which was used as guideline in this report; more than one-half of these samples were measured in the Rock Creek (44 samples) and Spring Branch Creek (41 samples) basins (table 20).

\section{Ecological Data}

Benthic macroinvertebrate samples were collected and habitat assessments were done at the nine base-flow and stormflow measuring sites in Independence (sites 1 through 9), one additional site in Independence (site 10), and two comparison sites (sites 12 and 13). Benthic macroinvertebrate samples were collected in March during WY 2007 through 2009, 2011, and 2013 for spring representation, and September during WY 2008, 2009, 2011, and 2012, and October 2010 for fall representation. Habitat assessments were done every other year beginning in WY 2008 (WYs 2008, 2010, and 2012).

\section{Macroinvertebrate Surveys}

Macroinvertebrate samples were processed, taxa enumerated, and taxa richness, abundance, and diversity metrics for macroinvertebrate samples were calculated using IDAS version 5.0 (Cuffney and Brightbill, 2011). Taxa by site and sampling date, as listed at the USGS NWQL, are presented in table 21 (http://pubs.usgs.gov/ds/0915/downloads/ds915 table21.xlsx).
Four metrics are used by the MDNR (Sarver, 2003a) in the calculation of the MSCI: RICH, EPTR, MBI, and SHANDIV (Sarver, 2003a). The range in the four metrics and the SCI for spring and fall samples for streams in Independence (sites 1 through 11) are shown in figure 15. Differences in the calculated SCI and component metrics for individual samples from previously published values (Christensen and Krempa, 2012) are not substantial and result from differences in resolving taxonomic ambiguities with the addition of more samples. Samples were collected during the spring and fall to account for seasonal variability in macroinvertebrate communities. Calculating SCI from a single season may not capture the range of ALS status of streams. The RICH and SHANDIV metrics values are noticeably higher during the spring, whereas the EPTR metric has higher values during the fall. The MBI metric seems similar in fall and spring. The total number of distinct taxa is higher and more diverse during the spring season. The number of Ephemeroptera, Plecoptera, and Trichoptera is higher and the overall condition of the streams, taking into account all metrics, is better during the fall season (table 22). The median tolerance of stream taxa is similar between the two seasons, with an MBI value of about 6 even though the tolerance of the taxa in the streams is somewhat broader in the fall than in the spring, with a greater abundance of lesser and greater-tolerant taxa (fig. 15; table 22).

Individual macroinvertebrate metric values and the SCI indices for samples by season along with selected field parameters are presented in table 22. Individual macroinvertebrate metric values varied substantially by site and year; however, seasonal median SCI scores for all Independence sites combined were the same despite some variability in component metrics (fig. 15). SCI scores indicated that 20 percent of spring Independence stream site samples met the criteria for full support of aquatic life and 80 percent were considered partially supportive, whereas fall samples for Independence sites indicated that 42 percent scored fully biologically supporting and 58 percent partially biologically supporting. No Independence stream sample had a non-supporting score using the criteria provided in table 3 .

\section{Habitat Assessments}

Stream habitat assessments were completed in the fall of 2008, 2010, and 2012, and in the spring of 2010 at each macroinvertebrate sampling site. A total possible score of 200 indicated ideal habitat. Habitat scores ranged from 65 (table 22) at site 7 in the spring of 2010 to 139 at the rural comparison site (site 13) in the spring of 2007, or between about 33 and 70 percent of the ideal score of 200. 
Table 18. Microbial source tracking marker concentrations for human and animal fecal source samples.

[ID, laboratory identification number; E. coli, Escherichia coli; MPN/gDW, most probable number per gram dry weight; copies/gDW, copies per gram dry weight; Human, individual human fecal source group; $\mathrm{OH}$, Ohio; e, exponent; --, no data; nd, not detected; bdl, below detection limit; <, less than; MO, Missouri; Livestock, livestock fecal source group; dnq, concentration is below the limit of quanitification but above the limit of detection; , duplicate qPCR results do not agree; E, estimated; Wildlife, wildlife fecal source group; Pet, pet fecal source group; MPN/100 mL, most probable number per 100 milliliters; copies/100 mL, copies per 100 milliliters; Mixed human, influent source sample group; >, greater than; na, not available (sample not collected)]

\begin{tabular}{|c|c|c|c|c|c|c|c|c|c|c|c|c|c|}
\hline $\begin{array}{c}\text { Laboratory } \\
\text { ID }\end{array}$ & Date & Source & Group & $\begin{array}{l}\text { E. coli } \\
\text { (MPN/ } \\
\text { gDW) }\end{array}$ & $\begin{array}{c}\text { E. coli } \\
\text { remark }\end{array}$ & $\begin{array}{c}\text { AllBac}^{1} \\
\text { (copies/ } \\
\text { gDW) }\end{array}$ & $\begin{array}{l}\text { AllBac } \\
\text { remark }\end{array}$ & $\begin{array}{c}\text { HF183 }^{2} \\
\text { (copies/ } \\
\text { gDW) }\end{array}$ & $\begin{array}{l}\text { HF183 } \\
\text { remark }\end{array}$ & $\begin{array}{c}\text { BacCan }^{3} \\
\text { (copies/ } \\
\text { gDW) }\end{array}$ & $\begin{array}{l}\text { BacCan } \\
\text { remark }\end{array}$ & $\begin{array}{c}\text { BoBac }^{4} \\
\text { (copies/ } \\
\text { gDW) }\end{array}$ & $\begin{array}{l}\text { BoBac } \\
\text { remark }\end{array}$ \\
\hline \multicolumn{14}{|c|}{ Human fecal samples } \\
\hline 2299-01 & $4 / 15 / 2013$ & Human OH Female 36 & Human & $6.00 \mathrm{e}+09$ & -- & $3.23 \mathrm{e}+11$ & -- & $1.51 \mathrm{e}+08$ & -- & -- & nd & -- & nd \\
\hline 2299-02 & $4 / 15 / 2013$ & Human OH Female 28 & Human & $1.00 \mathrm{e}+08$ & -- & $4.17 \mathrm{e}+11$ & -- & -- & bdl & -- & nd & -- & nd \\
\hline 2299-03 & $4 / 15 / 2013$ & Human OH Male 58 & Human & $8.80 \mathrm{e}+07$ & -- & $6.63 \mathrm{e}+11$ & -- & $5.19 \mathrm{e}+10$ & -- & -- & nd & -- & nd \\
\hline 2299-04 & $4 / 15 / 2013$ & Human OH Male 17 & Human & $9.40 \mathrm{e}+03$ & $<$ & $8.72 \mathrm{e}+11$ & -- & $3.05 \mathrm{e}+07$ & -- & -- & nd & -- & nd \\
\hline 2299-05 & $4 / 15 / 2013$ & Human MO Male 46 & Human & $1.40 \mathrm{e}+04$ & -- & $2.14 \mathrm{e}+12$ & -- & $3.12 \mathrm{e}+07$ & -- & -- & nd & $1.43 \mathrm{e}+11$ & -- \\
\hline 2299-06 & $4 / 15 / 2013$ & Human MO Male 21 & Human & $4.50 \mathrm{e}+07$ & -- & $5.46 \mathrm{e}+11$ & -- & $8.93 \mathrm{e}+10$ & -- & -- & nd & -- & nd \\
\hline 2299-07 & $4 / 15 / 2013$ & Human MO Male 56 & Human & $3.70 \mathrm{e}+06$ & -- & $8.07 \mathrm{e}+11$ & -- & $1.38 \mathrm{e}+08$ & -- & -- & nd & -- & nd \\
\hline 2299-08 & $4 / 15 / 2013$ & Human MO Male 52 & Human & $1.40 \mathrm{e}+04$ & $<$ & $3.18 \mathrm{e}+11$ & -- & -- & bdl & -- & nd & -- & nd \\
\hline 2299-09 & $4 / 15 / 2013$ & Human MO Male 50 & Human & $2.70 \mathrm{e}+08$ & -- & $1.29 \mathrm{e}+12$ & -- & $8.96 \mathrm{e}+07$ & -- & -- & nd & -- & nd \\
\hline $2300-01$ & $4 / 16 / 2013$ & Human MO Male 24 & Human & $1.60 \mathrm{e}+04$ & -- & $1.01 \mathrm{e}+12$ & -- & $8.68 \mathrm{e}+08$ & -- & -- & nd & -- & nd \\
\hline $2300-02$ & $4 / 16 / 2013$ & Human MO Male 35 & Human & $6.70 \mathrm{e}+08$ & -- & $5.62 \mathrm{e}+11$ & -- & $5.29 \mathrm{e}+07$ & -- & $2.17 \mathrm{e}+10$ & -- & $1.49 \mathrm{e}+10$ & -- \\
\hline $2300-03$ & $4 / 16 / 2013$ & Human MO Male 50-55 & Human & $9.30 \mathrm{e}+07$ & -- & $2.79 \mathrm{e}+12$ & -- & $1.42 \mathrm{e}+11$ & -- & -- & nd & -- & nd \\
\hline 2300-04 & $4 / 16 / 2013$ & Human MO Male 57 & Human & $3.20 \mathrm{e}+08$ & -- & $2.60 \mathrm{e}+12$ & -- & $1.08 \mathrm{e}+11$ & -- & -- & nd & -- & nd \\
\hline \multicolumn{14}{|c|}{ Ruminant fecal samples } \\
\hline 1998-03 & $10 / 24 / 2011$ & Cow number 1 & Livestock & $3.46 \mathrm{e}+04$ & -- & $4.03 \mathrm{e}+11$ & -- & $1.42 \mathrm{e}+06$ & -- & $2.33 \mathrm{e}+07$ & -- & $6.82 \mathrm{e}+10$ & -- \\
\hline 1998-04 & $10 / 24 / 2011$ & Cow number 2 & Livestock & $4.85 \mathrm{e}+03$ & -- & $3.68 \mathrm{e}+11$ & -- & $1.83 \mathrm{e}+06$ & -- & $6.13 \mathrm{e}+06$ & -- & $5.23 \mathrm{e}+10$ & -- \\
\hline 1998-05 & $10 / 24 / 2011$ & Cow number 3 & Livestock & $5.62 \mathrm{e}+04$ & -- & $2.99 \mathrm{e}+11$ & -- & $1.09 \mathrm{e}+06$ & -- & $1.72 \mathrm{e}+07$ & -- & $5.49 \mathrm{e}+10$ & -- \\
\hline 1998-06 & $10 / 24 / 2011$ & Cow number 4 & Livestock & $1.20 \mathrm{e}+08$ & -- & $1.81 \mathrm{e}+11$ & -- & $7.36 \mathrm{e}+05$ & -- & $2.13 \mathrm{e}+06$ & -- & $3.10 \mathrm{e}+10$ & -- \\
\hline 1998-07 & $10 / 24 / 2011$ & Cow number 5 & Livestock & $2.26 \mathrm{e}+08$ & -- & $1.25 \mathrm{e}+11$ & -- & -- & bdl & $4.08 \mathrm{e}+06$ & -- & $2.17 \mathrm{e}+10$ & -- \\
\hline 1998-08 & $10 / 24 / 2011$ & Cow number 6 & Livestock & $5.97 \mathrm{e}+06$ & -- & $2.80 \mathrm{e}+11$ & -- & $2.72 \mathrm{e}+05$ & dnq $\sim$ & $1.07 \mathrm{e}+06$ & $\mathrm{E} \sim$ & $4.05 \mathrm{e}+10$ & -- \\
\hline 1998-09 & $10 / 24 / 2011$ & Cow number 7 & Livestock & $3.02 \mathrm{e}+03$ & -- & $2.45 \mathrm{e}+11$ & -- & -- & bdl & $9.29 \mathrm{e}+06$ & -- & $4.12 \mathrm{e}+10$ & -- \\
\hline 1998-10 & $10 / 24 / 2011$ & Cow number 8 & Livestock & $9.67 \mathrm{e}+04$ & -- & $2.55 \mathrm{e}+11$ & -- & $8.65 \mathrm{e}+05$ & $\mathrm{E} \sim$ & $3.14 \mathrm{e}+06$ & -- & $2.37 \mathrm{e}+10$ & -- \\
\hline 1985-06 & 9/22/2011 & Deer number 1 & Wildlife & $4.13 \mathrm{e}+08$ & -- & $1.45 \mathrm{e}+10$ & -- & -- & bdl & $4.09 \mathrm{e}+06$ & -- & $7.08 \mathrm{e}+08$ & -- \\
\hline $1985-15$ & $9 / 22 / 2011$ & Deer number 10 & Wildlife & $5.33 \mathrm{e}+06$ & -- & $3.15 \mathrm{e}+11$ & -- & $1.25 \mathrm{e}+06$ & -- & $2.14 \mathrm{e}+07$ & -- & $1.22 \mathrm{e}+10$ & -- \\
\hline $1985-16$ & $9 / 22 / 2011$ & Deer number 11 & Wildlife & $7.06 \mathrm{e}+06$ & -- & $5.98 \mathrm{e}+10$ & -- & $4.40 \mathrm{e}+05$ & -- & $3.26 \mathrm{e}+05$ & dnq & $3.67 \mathrm{e}+09$ & -- \\
\hline 1985-10 & $9 / 22 / 2011$ & Deer number 5 & Wildlife & $3.32 \mathrm{e}+06$ & -- & $1.78 \mathrm{e}+11$ & -- & $3.46 \mathrm{e}+08$ & -- & $7.71 \mathrm{e}+07$ & -- & $9.06 \mathrm{e}+09$ & -- \\
\hline 1985-11 & $9 / 22 / 2011$ & Deer number 6 & Wildlife & $3.02 \mathrm{e}+06$ & -- & $1.15 \mathrm{e}+11$ & -- & $3.83 e+06$ & -- & $4.74 \mathrm{e}+07$ & -- & $8.98 \mathrm{e}+09$ & -- \\
\hline $1985-14$ & 9/22/2011 & Deer number 9 & Wildlife & $1.10 \mathrm{e}+06$ & -- & $2.38 \mathrm{e}+10$ & -- & $4.07 \mathrm{e}+05$ & -- & $4.48 \mathrm{e}+05$ & -- & $2.07 \mathrm{e}+09$ & -- \\
\hline
\end{tabular}


[ID, laboratory identification number; E. coli, Escherichia coli; MPN/gDW, most probable number per gram dry weight; copies/gDW, copies per gram dry weight; Human, individual human fecal source group; $\mathrm{OH}$, Ohio; e, exponent; --, no data; nd, not detected; bdl, below detection limit; <, less than; MO, Missouri; Livestock, livestock fecal source group; dnq, concentration is below the limit of quanitification but above the limit of detection; , duplicate qPCR results do not agree; E, estimated; Wildlife, wildlife fecal source group; Pet, pet fecal source group; MPN/100 mL, most probable number per 100 milliliters; copies/100 mL, copies per 100 milliliters; Mixed human, influent source sample group; >, greater than; na, not available (sample not collected)]

\begin{tabular}{|c|c|c|c|c|c|c|c|c|c|c|c|c|c|}
\hline $\begin{array}{c}\text { Laboratory } \\
\text { ID }\end{array}$ & Date & Source & Group & $\begin{array}{l}\text { E. coli } \\
\text { (MPN/ } \\
\text { gDW) }\end{array}$ & $\begin{array}{r}\text { E. coli } \\
\text { remark }\end{array}$ & $\begin{array}{c}\text { AllBac }^{1} \\
\text { (copies/ } \\
\text { gDW) }\end{array}$ & $\begin{array}{l}\text { AllBac } \\
\text { remark }\end{array}$ & $\begin{array}{c}\text { HF183² }^{2} \\
\text { (copies/ } \\
\text { gDW) }\end{array}$ & $\begin{array}{c}\text { HF183 } \\
\text { remark }\end{array}$ & $\begin{array}{c}\text { BacCan }^{3} \\
\text { (copies/ } \\
\text { gDW) }\end{array}$ & $\begin{array}{l}\text { BacCan } \\
\text { remark }\end{array}$ & $\begin{array}{c}\text { BoBac }^{4} \\
\text { (copies/ } \\
\text { gDW) }\end{array}$ & $\begin{array}{l}\text { BoBac } \\
\text { remark }\end{array}$ \\
\hline \multicolumn{14}{|c|}{ Canine fecal samples } \\
\hline $1985-01$ & $9 / 22 / 2011$ & Dog number 1 & Pet & $1.47 \mathrm{e}+07$ & -- & $1.17 \mathrm{e}+11$ & -- & $2.58 \mathrm{e}+06$ & -- & -- & nd & $1.39 \mathrm{e}+09$ & -- \\
\hline $2110-01$ & $7 / 10 / 2012$ & Dog number 1 & Pet & $7.87 \mathrm{e}+07$ & -- & $1.81 \mathrm{e}+11$ & -- & $7.67 \mathrm{e}+05$ & $\mathrm{E} \sim$ & $2.71 \mathrm{e}+08$ & -- & $3.88 \mathrm{e}+09$ & -- \\
\hline 1985-02 & 9/22/2011 & Dog number 2 & Pet & $9.96 \mathrm{e}+09$ & -- & $4.97 \mathrm{e}+11$ & -- & $1.01 \mathrm{e}+07$ & -- & $8.63 \mathrm{e}+10$ & -- & $4.56 \mathrm{e}+09$ & -- \\
\hline $2110-02$ & $7 / 10 / 2012$ & Dog number 2 & Pet & $9.24 \mathrm{e}+06$ & -- & $8.55 \mathrm{e}+11$ & -- & $3.03 \mathrm{e}+07$ & -- & $2.05 \mathrm{e}+11$ & -- & $1.80 \mathrm{e}+09$ & -- \\
\hline 1985-03 & $9 / 22 / 2011$ & Dog number 3 & Pet & $2.66 \mathrm{e}+09$ & -- & $3.40 \mathrm{e}+11$ & -- & $2.43 \mathrm{e}+07$ & -- & $4.01 \mathrm{e}+09$ & -- & $1.46 \mathrm{e}+09$ & -- \\
\hline $2110-03$ & $7 / 10 / 2012$ & Dog number 3 & Pet & $5.57 \mathrm{e}+00$ & -- & $8.88 \mathrm{e}+09$ & -- & -- & bdl & $5.47 \mathrm{e}+07$ & -- & $5.50 \mathrm{e}+08$ & -- \\
\hline $1985-04$ & $9 / 22 / 2011$ & Dog number 4 & Pet & $8.43 \mathrm{e}+00$ & -- & $2.60 \mathrm{e}+11$ & -- & $2.01 \mathrm{e}+06$ & -- & $5.46 \mathrm{e}+09$ & -- & $1.39 \mathrm{e}+09$ & -- \\
\hline 2110-04 & $7 / 10 / 2012$ & Dog number 4 & Pet & $1.06 \mathrm{e}+10$ & -- & $8.00 \mathrm{e}+11$ & -- & $8.93 \mathrm{e}+06$ & -- & -- & bdl & -- & bdl \\
\hline \multicolumn{14}{|c|}{ Other fecal samples } \\
\hline $2310-01$ & $5 / 8 / 2013$ & Chicken & Livestock & $1.60 \mathrm{e}+09$ & -- & $3.18 \mathrm{e}+07$ & -- & -- & bdl & -- & nd & $1.19 \mathrm{e}+05$ & dnq \\
\hline $2310-02$ & $5 / 8 / 2013$ & Chicken & Livestock & $1.30 \mathrm{e}+08$ & -- & $1.98 \mathrm{e}+06$ & -- & -- & nd & -- & nd & $3.42 \mathrm{e}+04$ & -- \\
\hline $2310-03$ & $5 / 8 / 2013$ & Cat & Pet & $5.60 \mathrm{e}+05$ & -- & $1.22 \mathrm{e}+11$ & -- & -- & nd & -- & nd & $4.01 \mathrm{e}+09$ & -- \\
\hline $2310-04$ & $5 / 8 / 2013$ & Turkey & Wildlife & $1.00 \mathrm{e}+02$ & -- & -- & bdl & -- & nd & -- & nd & -- & nd \\
\hline $2310-05$ & $5 / 8 / 2013$ & Mouse & Wildlife & $1.40 \mathrm{e}+05$ & -- & $1.56 \mathrm{e}+10$ & -- & -- & nd & $4.50 \mathrm{e}+05$ & -- & -- & nd \\
\hline $2310-06$ & $5 / 8 / 2013$ & Mouse & Wildlife & $1.40 \mathrm{e}+04$ & -- & $2.41 \mathrm{e}+10$ & -- & -- & nd & $3.88 \mathrm{e}+05$ & -- & -- & nd \\
\hline $1985-05$ & $9 / 22 / 2011$ & Goose & Wildlife & $1.50 \mathrm{e}+03$ & -- & $2.65 \mathrm{e}+07$ & -- & $4.01 \mathrm{e}+05$ & $\mathrm{E} \sim$ & -- & bdl & $2.22 \mathrm{e}+05$ & $\operatorname{dnq} \sim$ \\
\hline 1998-01 & $10 / 24 / 2011$ & Goose number 1 & Wildlife & $9.45 \mathrm{e}+00$ & $<$ & -- & bdl & $2.06 \mathrm{e}+06$ & -- & -- & nd & -- & nd \\
\hline 1998-02 & $10 / 24 / 2011$ & Goose number 2 & Wildlife & $1.14 \mathrm{e}+01$ & $<$ & $2.57 \mathrm{e}+07$ & -- & -- & nd & -- & nd & -- & nd \\
\hline $2310-07$ & $5 / 8 / 2013$ & Goose & Wildlife & $2.80 \mathrm{e}+01$ & $<$ & $7.79 \mathrm{e}+05$ & $\mathrm{E} \sim$ & -- & nd & -- & nd & -- & nd \\
\hline $2310-08$ & $5 / 8 / 2013$ & Rabbit & Wildlife & $9.60 \mathrm{e}+09$ & -- & $1.68 \mathrm{e}+08$ & -- & -- & nd & -- & nd & -- & nd \\
\hline 2313-01 & $5 / 14 / 2013$ & Horse & Livestock & $8.10 \mathrm{e}+08$ & -- & $3.18 \mathrm{e}+09$ & -- & -- & bdl & $4.19 \mathrm{e}+03$ & -- & -- & nd \\
\hline $2313-02$ & $5 / 14 / 2013$ & Horse & Livestock & $5.40 \mathrm{e}+06$ & -- & $1.29 \mathrm{e}+10$ & -- & -- & bdl & -- & bdl & -- & nd \\
\hline
\end{tabular}


Table 18. Microbial source tracking marker concentrations for human and animal fecal source samples.-Continued

[ID, laboratory identification number; E. coli, Escherichia coli; MPN/gDW, most probable number per gram dry weight; copies/gDW, copies per gram dry weight; Human, individual human fecal source group; $\mathrm{OH}$, Ohio; e, exponent; --, no data; nd, not detected; bdl, below detection limit; <, less than; MO, Missouri; Livestock, livestock fecal source group; dnq, concentration is below the limit of quanitification but above the limit of detection; , duplicate qPCR results do not agree; E, estimated; Wildlife, wildlife fecal source group; Pet, pet fecal source group; MPN/100 mL, most probable number per 100 milliliters; copies/100 mL, copies per 100 milliliters; Mixed human, influent source sample group; >, greater than; na, not available (sample not collected)]

\begin{tabular}{|c|c|c|c|c|c|c|c|c|c|c|c|c|c|}
\hline $\begin{array}{c}\text { Laboratory } \\
\text { ID }\end{array}$ & Date & Source & Group & $\begin{array}{c}\text { E. coli } \\
\text { (MPN/ } \\
100 \mathrm{~mL})\end{array}$ & $\begin{array}{c}\text { E. coli } \\
\text { remark }\end{array}$ & $\begin{array}{c}\text { AllBac}^{1} \\
\text { (copies/ } \\
100 \mathrm{~mL} \text { ) }\end{array}$ & $\begin{array}{l}\text { AllBac } \\
\text { remark }\end{array}$ & $\begin{array}{c}\text { HF183² }^{2} \\
\text { (copies/ } \\
100 \mathrm{~mL} \text { ) }\end{array}$ & $\begin{array}{c}\text { HF183 } \\
\text { remark }\end{array}$ & $\begin{array}{c}\text { BacCan }^{3} \\
\text { (copies/ } \\
100 \mathrm{~mL} \text { ) }\end{array}$ & $\begin{array}{l}\text { BacCan } \\
\text { remark }\end{array}$ & $\begin{array}{c}\text { BoBac }^{4} \\
\text { (copies/ } \\
100 \mathrm{~mL} \text { ) }\end{array}$ & $\begin{array}{l}\text { BoBac } \\
\text { remark }\end{array}$ \\
\hline \multicolumn{14}{|c|}{ Influent samples } \\
\hline $1976-05$ & $9 / 15 / 2011$ & Human influent & Mixed human & $2.40 \mathrm{e}+06$ & $>$ & $3.76 \mathrm{e}+09$ & -- & $1.27 \mathrm{e}+08$ & -- & $3.56 \mathrm{e}+06$ & -- & $8.04 \mathrm{e}+06$ & -- \\
\hline $2022-02$ & $12 / 1 / 2011$ & Human influent & Mixed human & na & na & $1.42 \mathrm{e}+09$ & -- & $7.06 \mathrm{e}+07$ & -- & $8.80 \mathrm{e}+05$ & -- & $4.16 \mathrm{e}+06$ & -- \\
\hline 2033-07 & $1 / 19 / 2012$ & Human influent & Mixed human & na & na & $5.84 \mathrm{e}+09$ & -- & $1.77 \mathrm{e}+08$ & -- & $5.37 \mathrm{e}+06$ & -- & $6.28 \mathrm{e}+06$ & -- \\
\hline 2060-01 & $5 / 22 / 2012$ & Human influent & Mixed human & $5.50 \mathrm{e}+05$ & -- & $1.28 \mathrm{e}+10$ & -- & $4.13 \mathrm{e}+08$ & -- & $1.23 \mathrm{e}+07$ & -- & $2.05 \mathrm{e}+07$ & -- \\
\hline 2223-02 & $9 / 18 / 2012$ & Human influent & Mixed human & $6.10 \mathrm{e}+06$ & -- & $1.24 \mathrm{e}+10$ & -- & $1.09 \mathrm{e}+09$ & -- & $1.06 \mathrm{e}+07$ & -- & $2.99 \mathrm{e}+07$ & -- \\
\hline $2266-01$ & $11 / 29 / 2012$ & Human influent & Mixed human & $2.60 \mathrm{e}+07$ & -- & $5.83 \mathrm{e}+09$ & -- & $2.45 \mathrm{e}+08$ & -- & $6.95 \mathrm{e}+06$ & -- & $2.50 \mathrm{e}+07$ & -- \\
\hline $2281-07$ & $2 / 6 / 2013$ & Human influent & Mixed human & $5.00 \mathrm{e}+06$ & -- & $7.17 \mathrm{e}+09$ & -- & $2.48 \mathrm{e}+08$ & -- & $9.40 \mathrm{e}+06$ & -- & $3.02 \mathrm{e}+07$ & -- \\
\hline $2286-02$ & $3 / 5 / 2013$ & Human influent & Mixed human & $1.00 \mathrm{e}+06$ & -- & $3.20 \mathrm{e}+09$ & -- & $1.31 \mathrm{e}+08$ & -- & $4.32 \mathrm{e}+06$ & -- & $2.19 \mathrm{e}+07$ & -- \\
\hline 2297-01 & 4/9/2013 & Human influent & Mixed human & $1.30 \mathrm{e}+06$ & -- & $4.10 \mathrm{e}+09$ & -- & $1.31 \mathrm{e}+08$ & -- & $4.16 \mathrm{e}+06$ & -- & $2.34 \mathrm{e}+07$ & -- \\
\hline $2299-10$ & $4 / 15 / 2013$ & Human influent & Mixed human & $1.10 \mathrm{e}+06$ & -- & $2.19 \mathrm{e}+09$ & -- & $1.05 \mathrm{e}+08$ & -- & $1.39 \mathrm{e}+06$ & -- & $1.30 \mathrm{e}+07$ & -- \\
\hline 2306-01 & $4 / 23 / 2013$ & Human influent & Mixed human & $1.40 \mathrm{e}+06$ & -- & $6.62 \mathrm{e}+09$ & -- & $3.44 \mathrm{e}+08$ & -- & $4.83 \mathrm{e}+06$ & -- & $2.58 \mathrm{e}+07$ & -- \\
\hline 2319-01 & $5 / 29 / 2013$ & Human influent & Mixed human & $1.30 \mathrm{e}+06$ & -- & $3.83 \mathrm{e}+09$ & -- & $2.40 \mathrm{e}+08$ & -- & $4.34 \mathrm{e}+06$ & -- & $2.97 \mathrm{e}+07$ & -- \\
\hline
\end{tabular}

${ }^{1}$ AllBac, assay for general fecal contamination (Layton and others, 2006).

${ }^{2} \mathrm{HF} 183$, assay for human-associated fecal contamination (Seurinck and others, 2005).

${ }^{3} \mathrm{BacCan}$, assay for canine-associated fecal contamination (Kildare and others, 2005).

${ }^{4} \mathrm{BoBac}$, assay for ruminant-associated fecal contamination (Layton and others, 2006). 


\section{Hydrological, Water-Quality, and Ecological Data for Streams in Independence, Missouri}

Table 20. Summary of dry-weather screening constituent detections in streams in Independence, Missouri, water years 2006 through 2013.

[Water year, from October 1 of previous year to September 30; mg/L, milligrams per liter; All basins, combination of all data for all streams; EDL, estimated detection limit; MDL, method detection limit; results are semiquantitative]

\begin{tabular}{|c|c|c|c|c|c|}
\hline $\begin{array}{c}\text { Sample } \\
\text { water year }\end{array}$ & Statistic & $\begin{array}{c}\text { Total } \\
\text { chlorine } \\
\text { (mg/L) }\end{array}$ & $\begin{array}{c}\text { Total } \\
\text { dissolved } \\
\text { copper } \\
\text { (mg/L) } \\
\end{array}$ & $\begin{array}{c}\text { Phenols } \\
\text { (mg/L) }\end{array}$ & $\begin{array}{l}\text { Anionic } \\
\text { surfactant } \\
\text { (mg/L) }\end{array}$ \\
\hline \multicolumn{6}{|c|}{ All basins (table 2; fig. 2)-1,052 samples collected } \\
\hline \multirow[t]{10}{*}{ 2006-2013 } & Analyses & 1,049 & 803 & 1,035 & 1,048 \\
\hline & Detections $^{1}$ & 983 & 226 & 601 & 726 \\
\hline & Percent deleted ${ }^{2}$ & 0.38 & 4.98 & 1.62 & 0.38 \\
\hline & Minimum $^{3}$ & 0.02 & 0.04 & 0.002 & 0.002 \\
\hline & Maximum $^{3}$ & 7.00 & 0.49 & 0.200 & 12.100 \\
\hline & Average $^{3}$ & 0.08 & 0.07 & 0.007 & 0.043 \\
\hline & Median $^{3}$ & 0.06 & 0.06 & 0.004 & 0.011 \\
\hline & $\mathrm{EDL}^{4}$ & 0.02 & 0.04 & 0.002 & 0.002 \\
\hline & $\mathrm{MDL}^{5}$ & 0.05 & 0.05 & 0.005 & 0.010 \\
\hline & $\begin{array}{c}\text { Number above } \\
\text { guideline }^{6}\end{array}$ & 73 & 0 & 1 & 133 \\
\hline
\end{tabular}

\begin{tabular}{llcccc}
\hline \multicolumn{5}{c}{ Adair Creek Basin (table 2; fig. 2) } \\
\hline $\begin{array}{l}2007,2008, \\
2010\end{array}$ & Analyses & 197 & 197 & 197 & 197 \\
& Detections $^{1}$ & 176 & 53 & 121 & 182 \\
& Minimum $^{3}$ & 0.02 & 0.04 & 0.002 & 0.002 \\
& Maximum $^{3}$ & 1.89 & 0.22 & 0.019 & 0.278 \\
& Average $^{3}$ & 0.07 & 0.06 & 0.005 & 0.019 \\
& $\begin{array}{l}\text { Median }^{3} \\
\text { Number above } \\
\text { guideline }^{6}\end{array}$ & 0.05 & 0.05 & 0.003 & 0.012 \\
& 7 & 0 & 0 & 14
\end{tabular}

\begin{tabular}{|c|c|c|c|c|c|}
\hline \multicolumn{6}{|c|}{ East Fork Little Blue River Basin (table 2; fig. 2) } \\
\hline 2009 & Analyses & 4 & 4 & 4 & 4 \\
\hline & Detections $^{1}$ & 4 & 2 & 1 & 4 \\
\hline & Minimum $^{3}$ & 0.08 & 0.04 & 0.02 & 0.01 \\
\hline & Maximum $^{3}$ & 0.11 & 0.06 & 0.02 & 0.02 \\
\hline & Average $^{3}$ & 0.10 & 0.05 & 0.02 & 0.02 \\
\hline & Median $^{3}$ & 0.10 & 0.05 & 0.02 & 0.02 \\
\hline & $\begin{array}{c}\text { Number above } \\
\text { guideline }^{6}\end{array}$ & 0 & 0 & 0 & 0 \\
\hline
\end{tabular}

\begin{tabular}{|c|c|c|c|c|c|}
\hline \multicolumn{6}{|c|}{ Crackerneck Creek Basin (table 2; fig. 2) } \\
\hline 2006,2013 & Analyses & 49 & 49 & 49 & 49 \\
\hline & Detections $^{1}$ & 45 & 1 & 18 & 41 \\
\hline & Minimum $^{3}$ & 0.02 & 0.05 & 0.002 & 0.002 \\
\hline & Maximum $^{3}$ & 0.15 & 0.05 & 0.045 & 0.218 \\
\hline & Average $^{3}$ & 0.05 & 0.05 & 0.010 & 0.023 \\
\hline & Median $^{3}$ & 0.05 & 0.05 & 0.008 & 0.015 \\
\hline & $\begin{array}{c}\text { Number above } \\
\text { guideline }^{6}\end{array}$ & 1 & 0 & 0 & 12 \\
\hline
\end{tabular}

\begin{tabular}{llcccc}
\hline \multicolumn{5}{l}{ Spring Branch Creek Basin (table 2; fig. 2) } \\
\hline $\begin{array}{l}2006,2009, \\
2011, \\
2012\end{array}$ & Analyses & 258 & 258 & 258 & 258 \\
& & & & & \\
& Detections $^{1}$ & 245 & 39 & 146 & 233 \\
& Minimum $^{3}$ & 0.02 & 0.04 & 0.002 & 0.002 \\
& Maximum $^{3}$ & 0.43 & 0.18 & 0.033 & 1.940 \\
& Average $^{3}$ & 0.08 & 0.07 & 0.008 & 0.027 \\
& Median $^{3}$ & 0.07 & 0.06 & 0.006 & 0.011 \\
& Number above $^{\text {guideline }^{6}}$ & 35 & 0 & 0 & 41
\end{tabular}


Table 20. Summary of dry-weather screening constituent detections in streams in Independence, Missouri, water years 2006 through 2013.-Continued

[Water year, from October 1 of previous year to September 30; mg/L, milligrams per liter; All basins, combination of all data for all streams; EDL, estimated detection limit; MDL, method detection limit; results are semiquantitative]

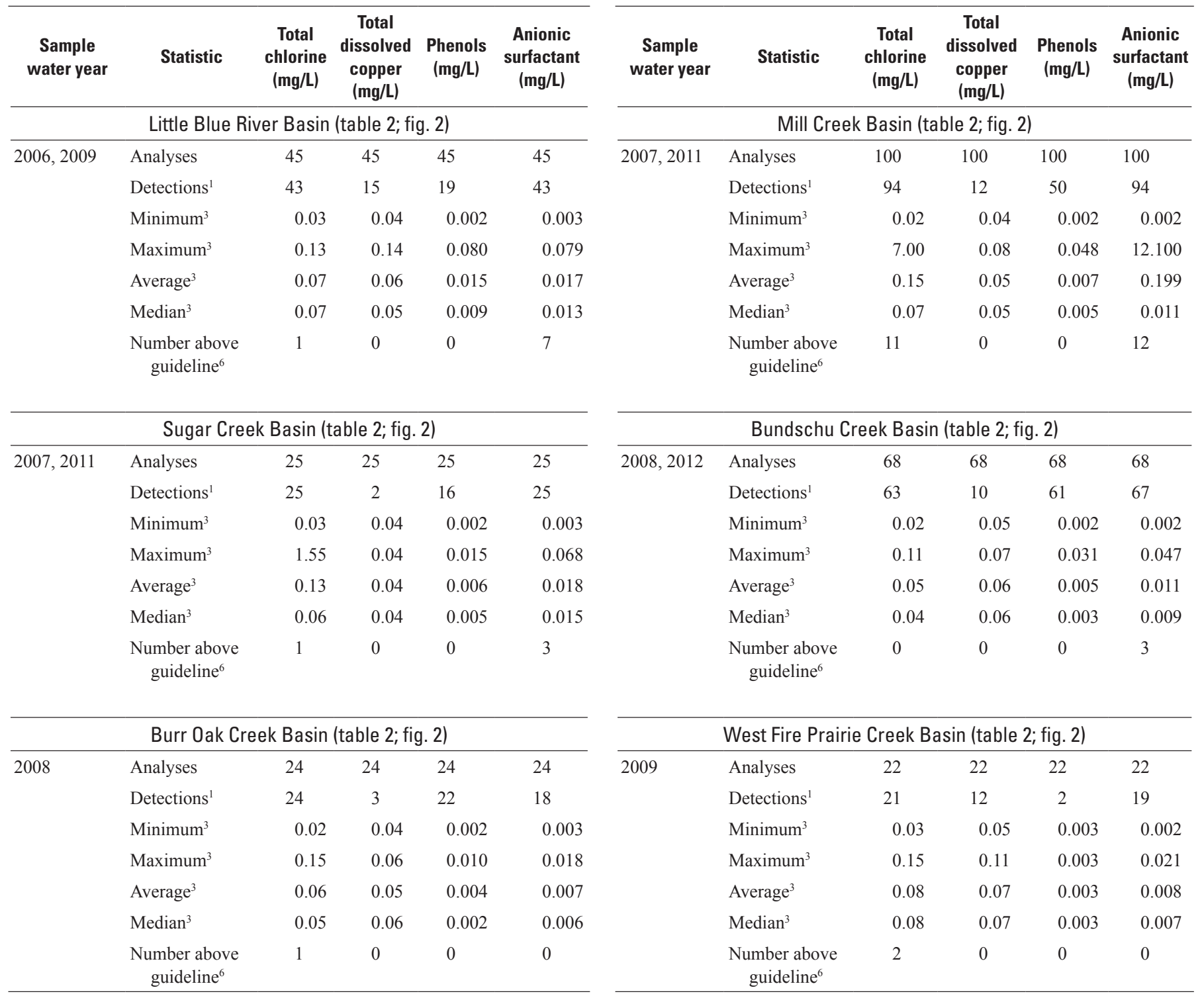

${ }^{1}$ Number of detections is the number of samples for each analyte with concentrations greater than the EDL.

${ }^{2}$ Percent of values deleted due to suspected interferences.

${ }^{3}$ Minimum, maximum, average, and median values are calculated from data that may contain estimated values. Values less than the provisional method detection limit were not included in the stastical analysis.

${ }^{4}$ The EDL is determine by Hach Company( $)$, the manufacturer of the analyte tests.

${ }^{5}$ The provisional MDL is determined by a comparison of the results of the environmental samples with the replicate and duplicate samples.

${ }^{6}$ Number of detections greater than a specific Federal or Missouri State standard or guideline. 


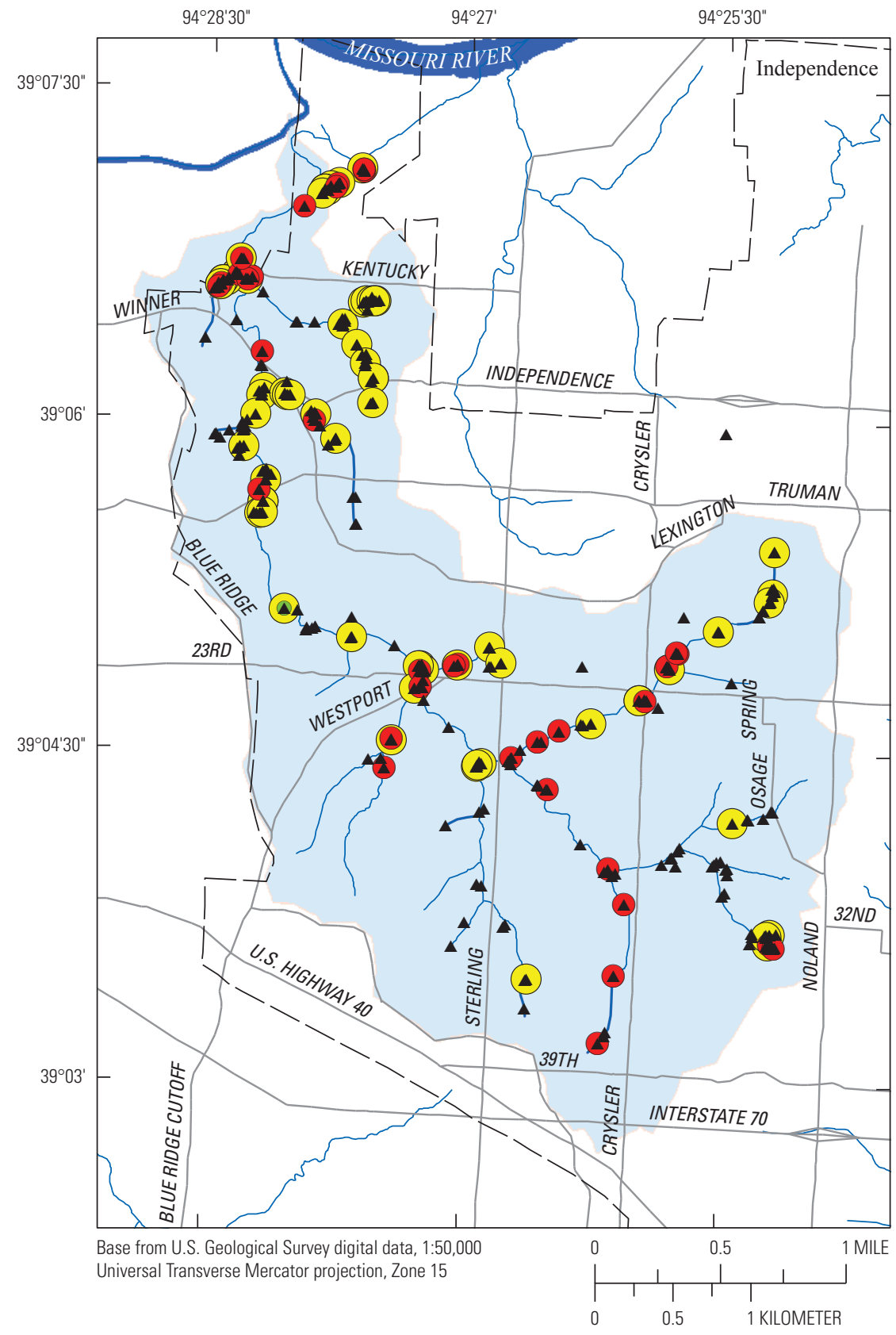

EXPLANATION

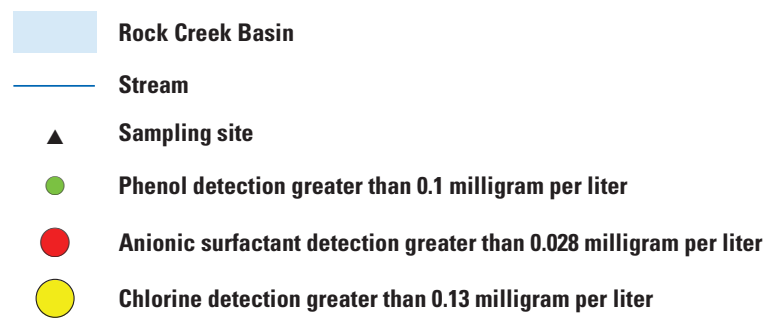

Figure 13. Dry-weather screening sampling sites and locations of constituent detections for selected stream basins in Independence, Missouri, water years 2006 through 2013. 


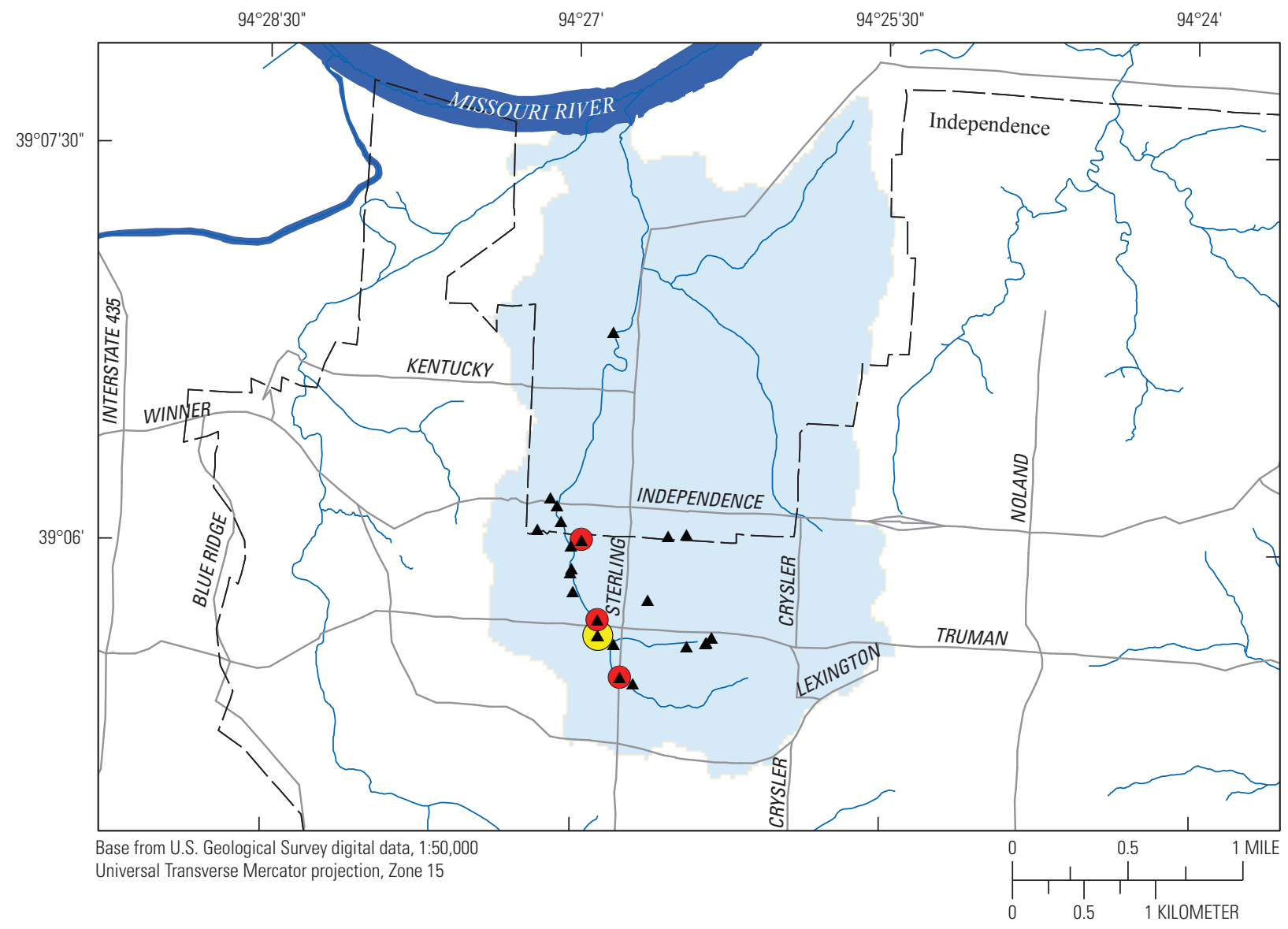

EXPLANATION

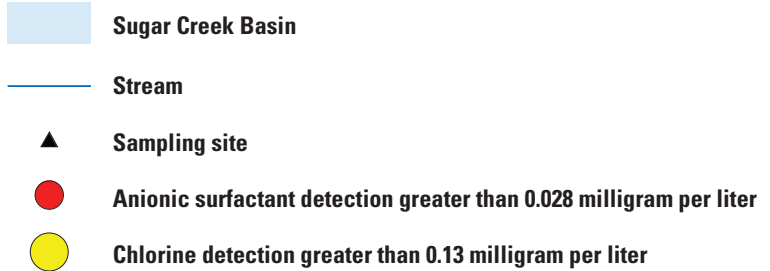

Figure 13. Dry-weather screening sampling sites and locations of constituent detections for selected stream basins in Independence, Missouri, water years 2006 through 2013.-Continued 


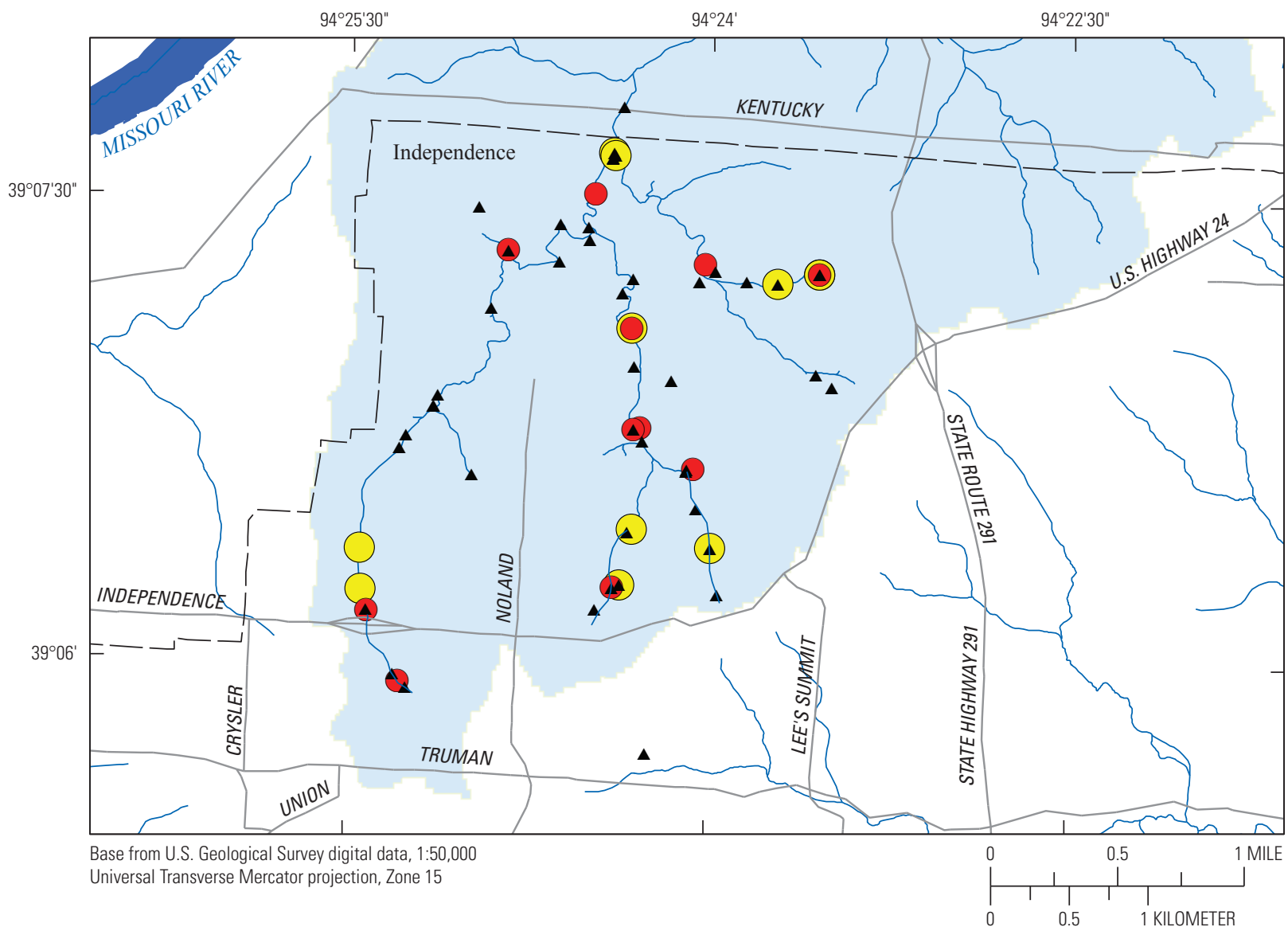

EXPLANATION

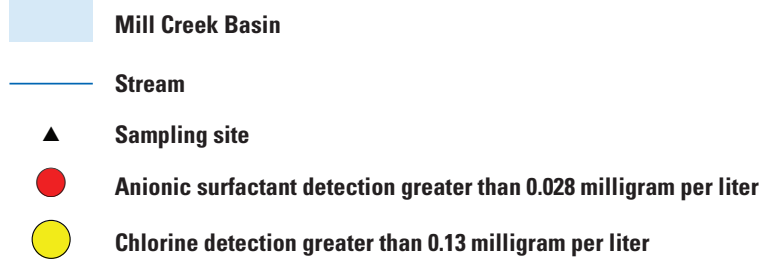

Figure 13. Dry-weather screening sampling sites and locations of constituent detections for selected stream basins in Independence, Missouri, water years 2006 through 2013._Continued 


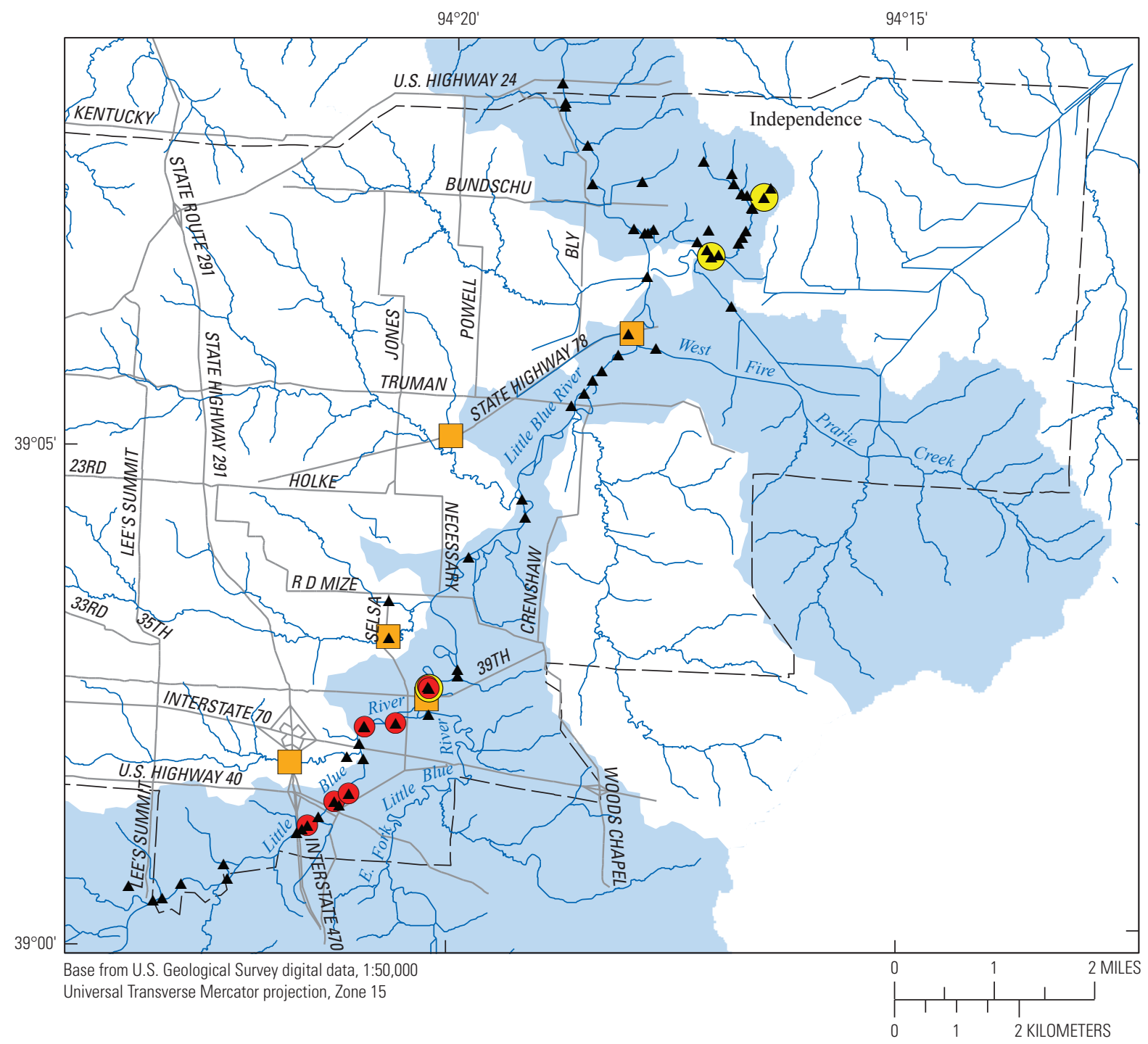

EXPLANATION

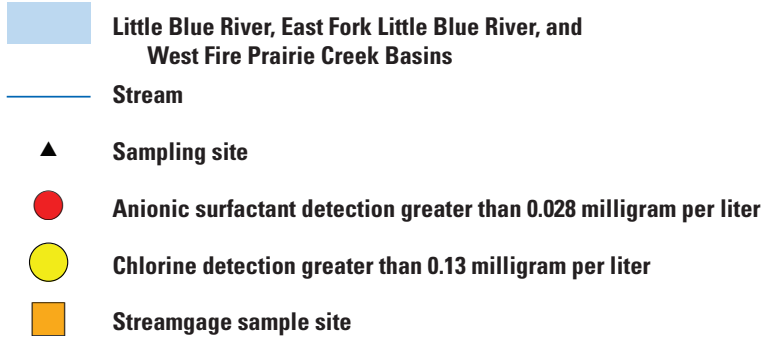

Figure 13. Dry-weather screening sampling sites and locations of constituent detections for selected stream basins in Independence, Missouri, water years 2006 through 2013.-Continued 


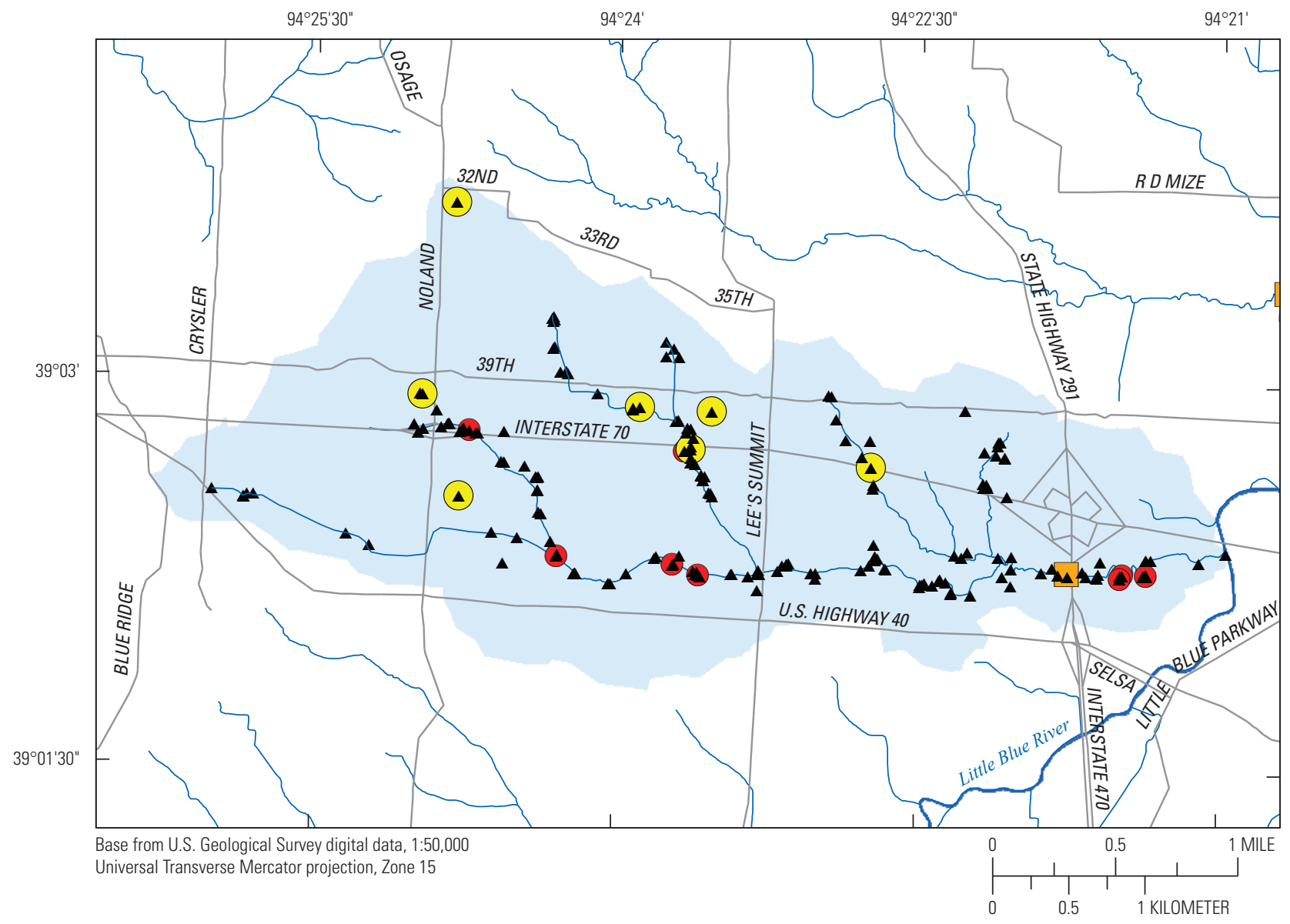

EXPLANATION

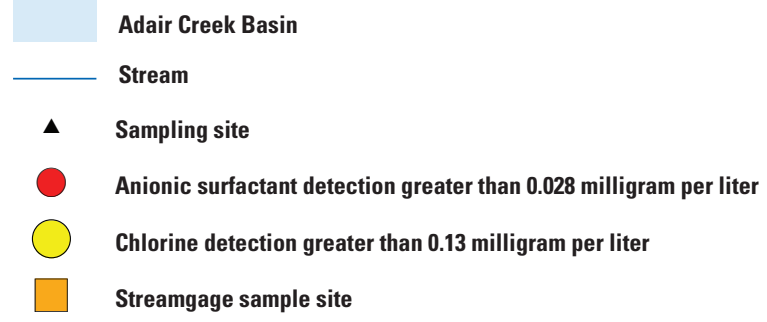

Figure 13. Dry-weather screening sampling sites and locations of constituent detections for selected stream basins in Independence, Missouri, water years 2006 through 2013.-Continued 


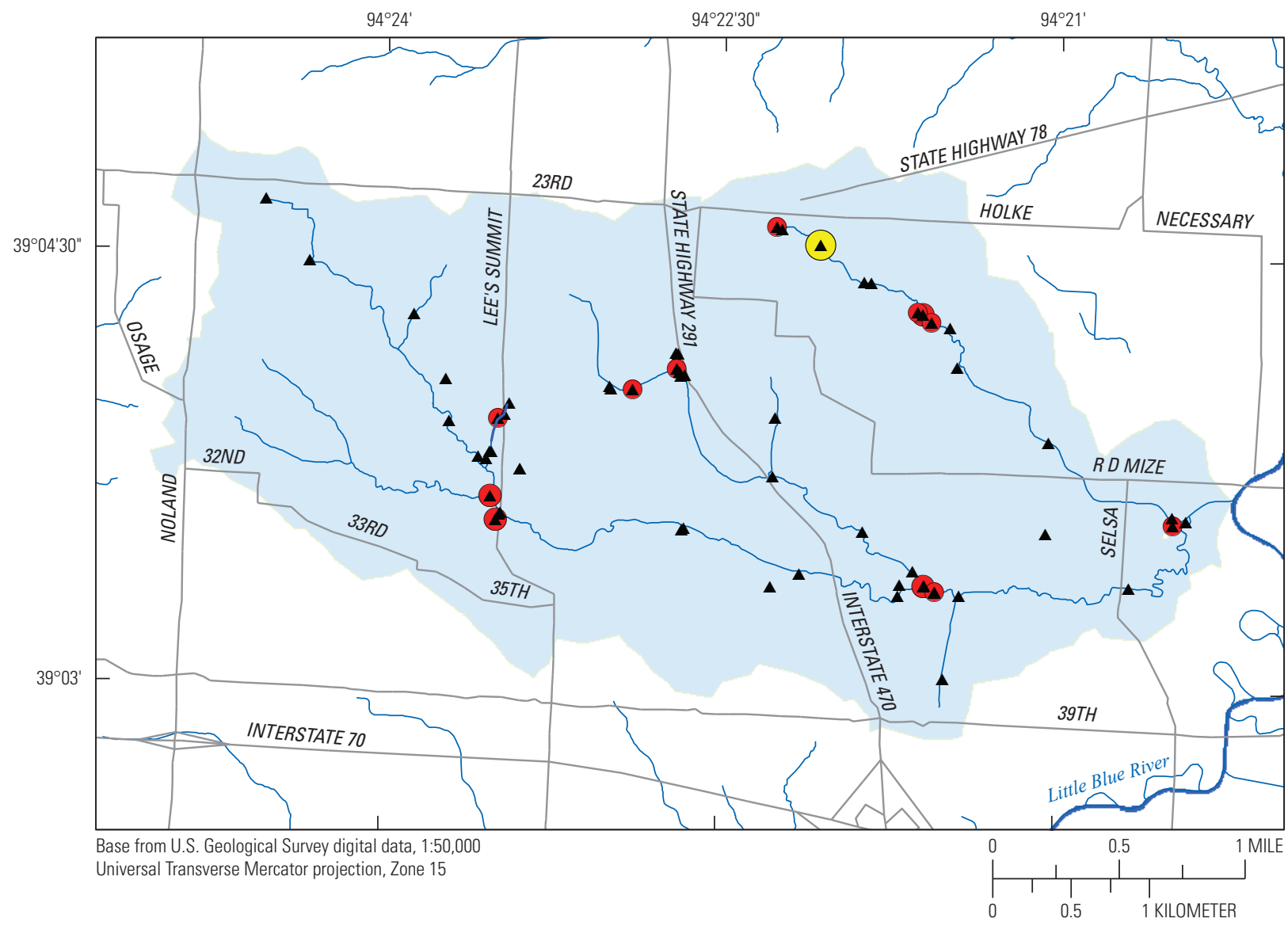

EXPLANATION

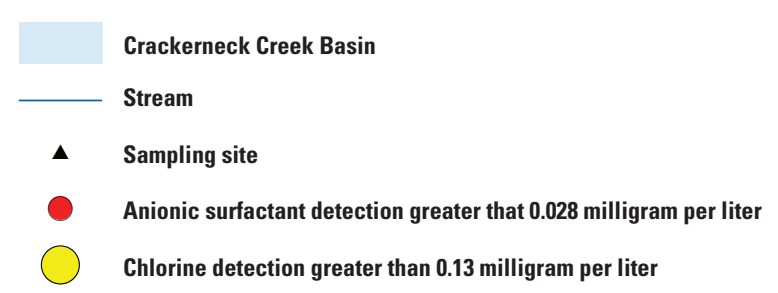

Figure 13. Dry-weather screening sampling sites and locations of constituent detections for selected stream basins in Independence, Missouri, water years 2006 through 2013. - Continued 


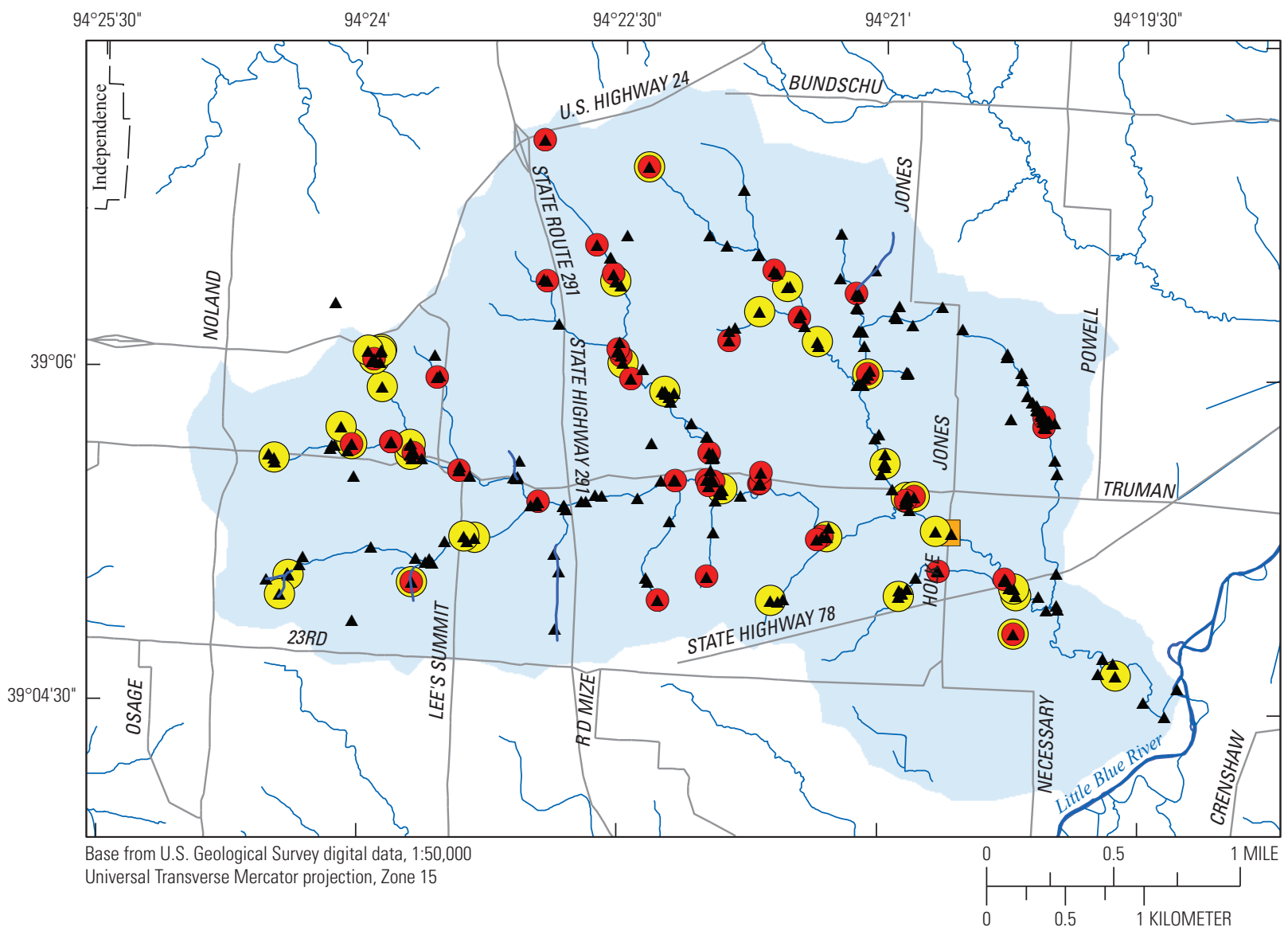

EXPLANATION

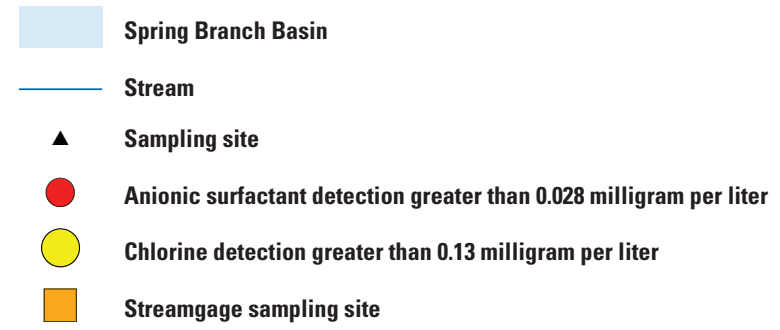

Figure 13. Dry-weather screening sampling sites and locations of constituent detections for selected stream basins in Independence, Missouri, water years 2006 through 2013.-Continued 


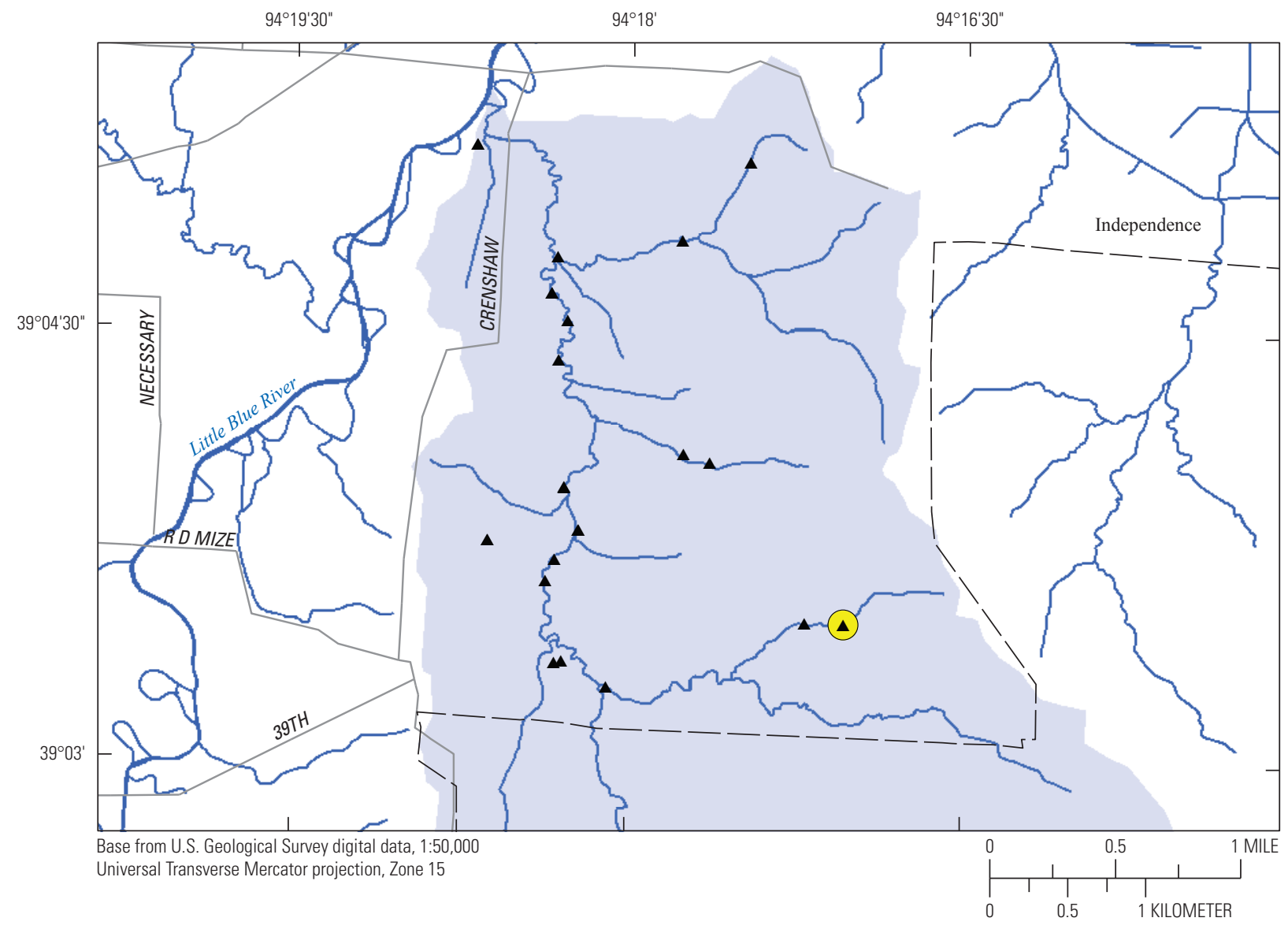

EXPLANATION

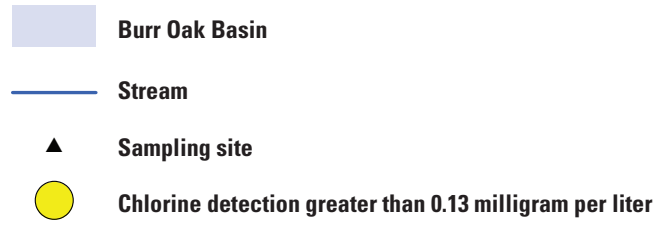

Figure 13. Dry-weather screening sampling sites and locations of constituent detections for selected stream basins in Independence, Missouri, water years 2006 through 2013.-Continued 


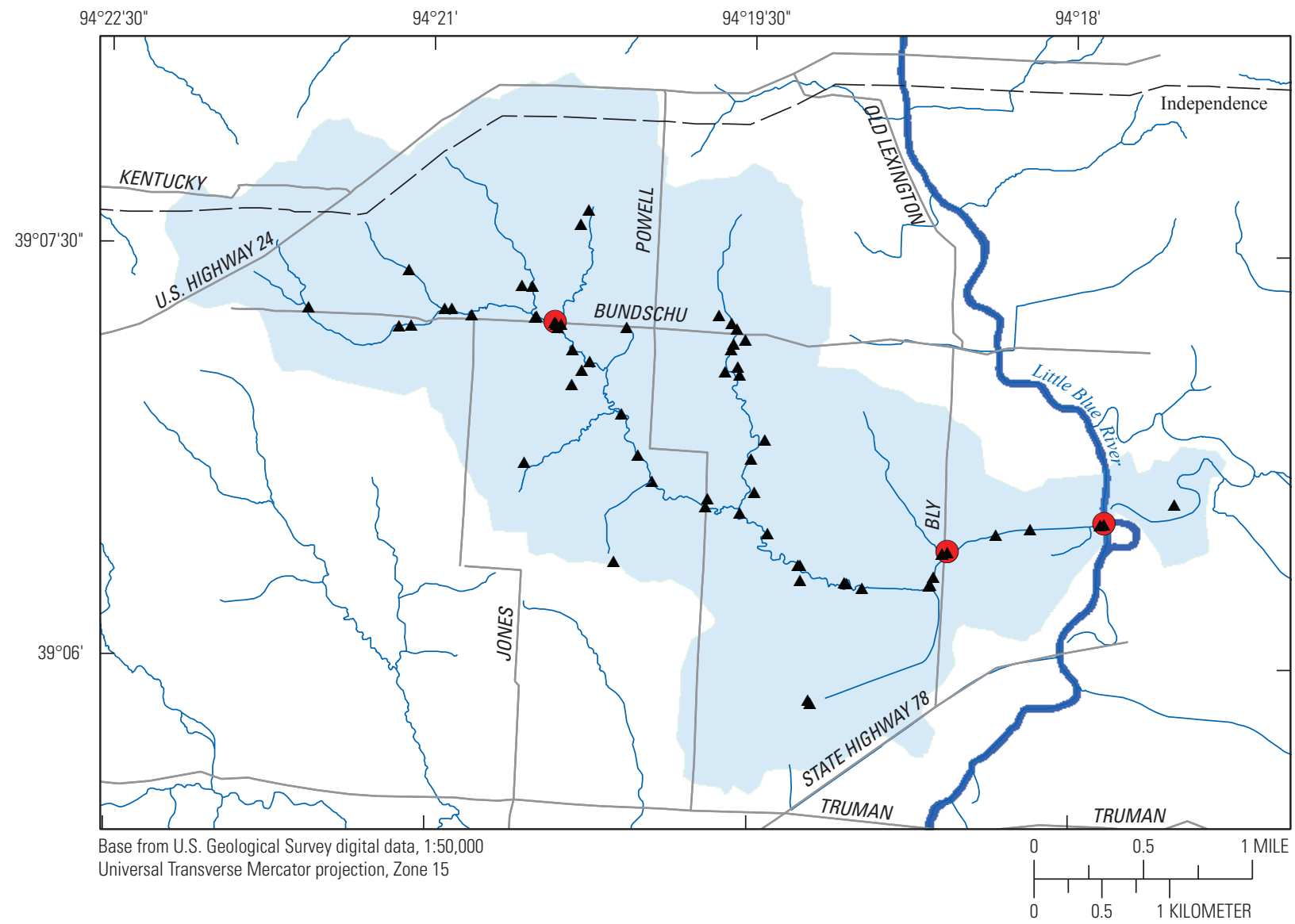

EXPLANATION

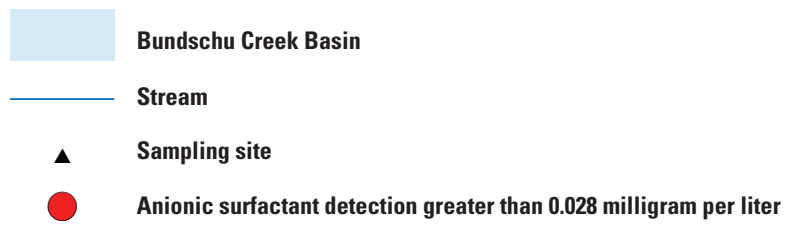

Figure 13. Dry-weather screening sampling sites and locations of constituent detections for selected stream basins in Independence, Missouri, water years 2006 through 2013.-Continued 

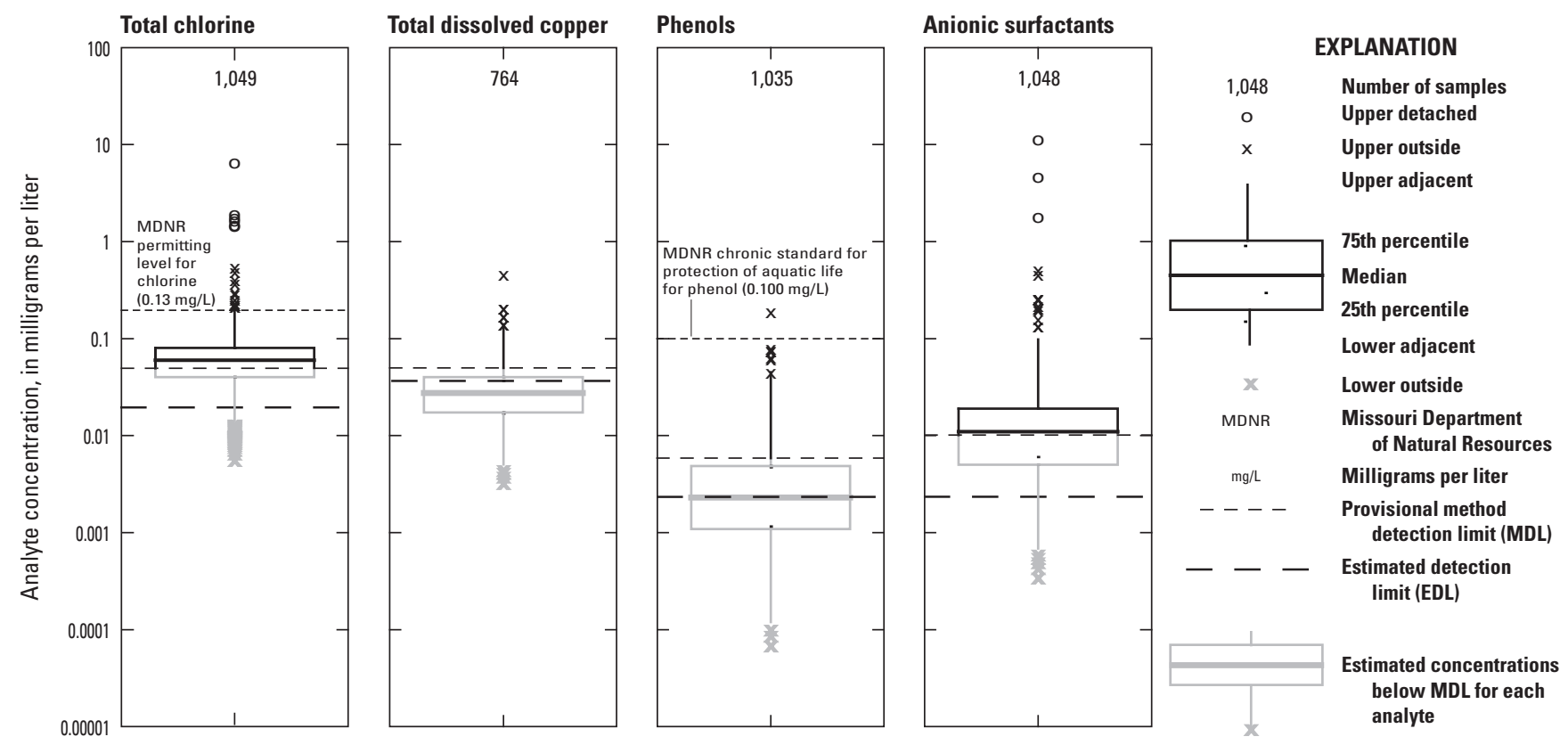

Figure 14. Boxplots of dry-weather screening constituent concentrations in streams in Independence, Missouri, water years 2006 through 2013. 

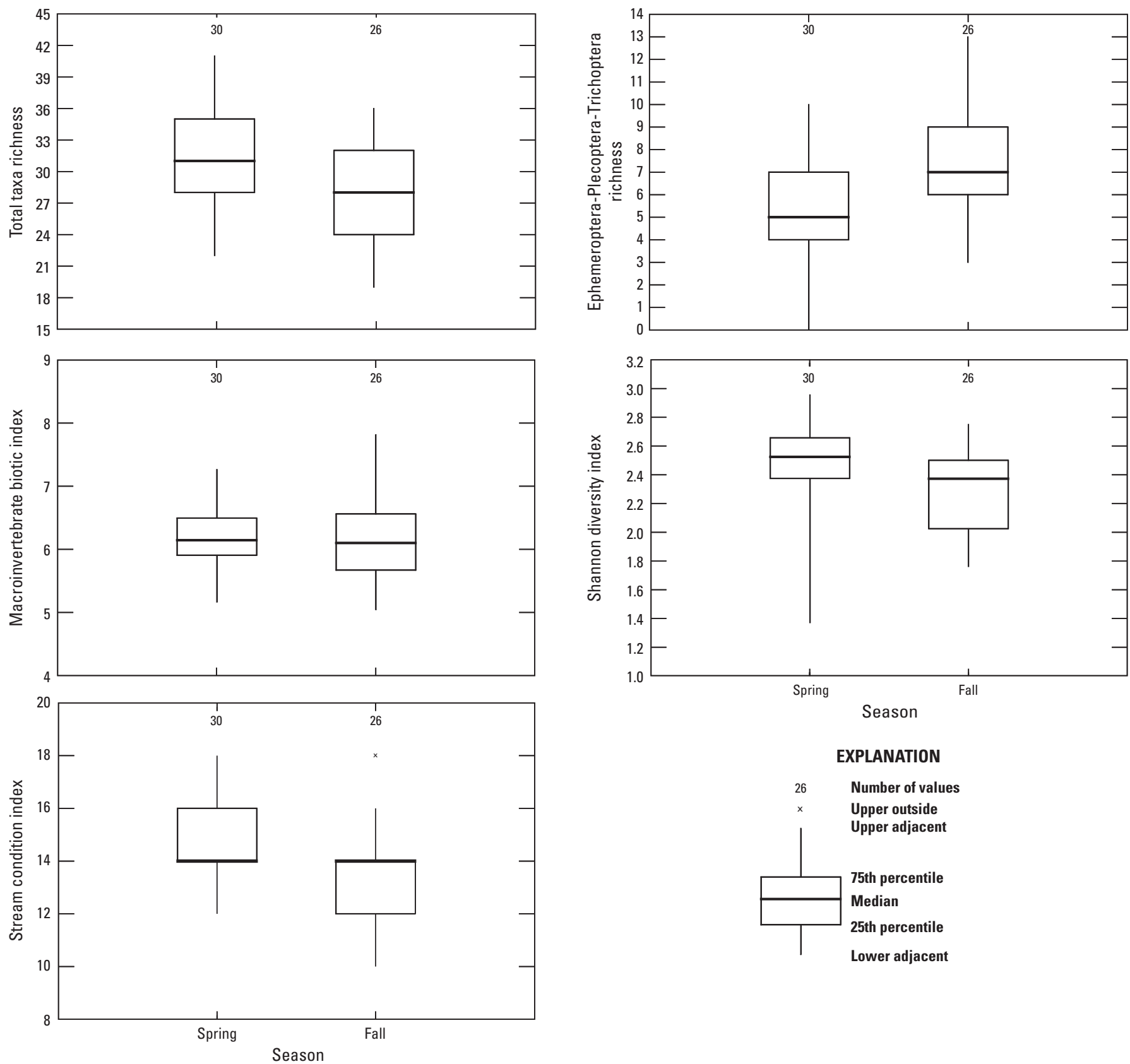

Figure 15. Macroinvertebrate taxa and individuals enumerated in samples from all sites, March 2007 through March 2013. 
Table 22. Habitat scores, dissolved oxygen, pH, specific conductance, water temperature, macroinvertebrate metrics used in the stream condition index, and aquatic-life support status for samples collected March 2007 through March 2013.

[STAID, station identification number; $\mathrm{mg} / \mathrm{L}$, milligrams per liter; $\mu \mathrm{S}$ at $25^{\circ} \mathrm{C}$, microsiemens per centimeter at 25 degrees Celsius; RICH, total taxa richness; EPTR, Ephemeroptera-Plecoptera-Trichoptera taxa richness; MBI, Macroinvertebrate Biotic Index; SHANDIV, Shannon Diversity Index; SCI, stream condition index; ALS, aquatic-life support status; --, no data; PBS, partially biologically supporting; FBS, fully biologically supporting; NBS, nonbiologically supporting]

\begin{tabular}{|c|c|c|c|c|c|c|c|c|c|c|c|c|c|c|c|c|c|}
\hline $\begin{array}{c}\text { Site } \\
\text { number } \\
\text { (table 2; } \\
\text { fig. 1) }\end{array}$ & STAID & $\begin{array}{c}\text { Sample } \\
\text { collection } \\
\text { date }\end{array}$ & $\begin{array}{c}\text { Habitat } \\
\text { score }\end{array}$ & $\begin{array}{c}\text { Dissolved } \\
\text { oxygen } \\
\text { (mg/L) }\end{array}$ & $\begin{array}{c}\text { pH } \\
\text { (standard } \\
\text { units) }\end{array}$ & $\begin{array}{c}\text { Specific } \\
\text { conductance } \\
\left(\mu \mathrm{S} \text { at } 25^{\circ} \mathrm{C}\right)\end{array}$ & $\begin{array}{c}\text { Water } \\
\text { temperature } \\
\left({ }^{\circ} \mathrm{C}\right)\end{array}$ & RICH & EPTR & MBI & SHANDIV & $\begin{array}{l}\text { RICH } \\
\text { Score }\end{array}$ & $\begin{array}{l}\text { EPTR } \\
\text { Score }\end{array}$ & $\begin{array}{l}\text { MBI } \\
\text { Score }\end{array}$ & $\begin{array}{l}\text { SHANDIV } \\
\text { Score }\end{array}$ & SCI ${ }^{1}$ & $\begin{array}{c}\text { ALS } \\
\text { rating }{ }^{2}\end{array}$ \\
\hline \multicolumn{18}{|c|}{ Spring samples } \\
\hline 1 & 06893620 & $3 / 20 / 2007$ & -- & 12.5 & 7.7 & 879 & 11.0 & 27 & 5 & 6.49 & 2.27 & 3 & 3 & 3 & 3 & 12 & PBS \\
\hline 1 & 06893620 & $3 / 26 / 2008$ & -- & 12.6 & 7.7 & 797 & 8.2 & 26 & 4 & 6.57 & 2.37 & 3 & 1 & 3 & 5 & 12 & PBS \\
\hline 1 & 06893620 & $3 / 17 / 2009$ & -- & 10.8 & 7.7 & 850 & 12.4 & 30 & 7 & 6.61 & 2.79 & 3 & 3 & 3 & 5 & 14 & PBS \\
\hline 1 & 06893620 & 4/19/2010 & 110 & 11.2 & 7.8 & 794 & 14.6 & -- & -- & -- & -- & -- & -- & -- & -- & -- & -- \\
\hline 1 & 06893620 & $3 / 15 / 2011$ & -- & 10.7 & 6.9 & 815 & 5.1 & 27 & 6 & 5.88 & 2.61 & 3 & 3 & 3 & 5 & 14 & PBS \\
\hline 1 & 06893620 & $3 / 20 / 2013$ & -- & 13.2 & 8.0 & 763 & 4.5 & 31 & 5 & 5.80 & 2.62 & 3 & 3 & 3 & 5 & 14 & PBS \\
\hline 1 & 06893620 & $3 / 21 / 2013$ & -- & 13.2 & 8.0 & 725 & 4.0 & 35 & 7 & 5.94 & 2.75 & 3 & 3 & 3 & 5 & 14 & PBS \\
\hline 2 & 06893820 & $4 / 14 / 2010$ & 90 & 12.3 & 7.6 & 620 & 18.3 & -- & -- & -- & -- & -- & -- & -- & -- & -- & -- \\
\hline 2 & 06893820 & $3 / 15 / 2011$ & -- & 12.4 & 8.0 & 868 & 5.0 & 37 & 10 & 6.13 & 2.62 & 5 & 5 & 3 & 5 & 18 & FBS \\
\hline 2 & 06893820 & $3 / 18 / 2013$ & -- & 11.8 & 8.2 & 562 & 5.3 & 36 & 10 & 5.99 & 2.96 & 3 & 5 & 3 & 5 & 16 & FBS \\
\hline 3 & 06893830 & $3 / 18 / 2009$ & & 14.4 & 7.6 & 855 & 10.5 & 31 & 5 & 6.88 & 2.69 & 3 & 3 & 3 & 5 & 14 & PBS \\
\hline 3 & 06893830 & 4/16/2010 & 73 & 9.0 & 8.2 & 961 & 20.1 & -- & -- & -- & -- & -- & -- & -- & -- & -- & -- \\
\hline 3 & 06893830 & $3 / 10 / 2011$ & & 13.0 & 7.7 & 1,240 & 5.4 & 28 & 2 & 6.05 & 2.57 & 3 & 1 & 3 & 5 & 12 & PBS \\
\hline 3 & 06893830 & $3 / 19 / 2013$ & -- & -- & -- & 1,190 & 7.1 & 26 & 2 & 5.17 & 2.10 & 3 & 1 & 5 & 3 & 12 & PBS \\
\hline 4 & 06893890 & $3 / 16 / 2011$ & -- & 13.0 & 7.2 & 401 & 6.4 & 37 & 4 & 7.00 & 2.70 & 5 & 1 & 3 & 5 & 14 & PBS \\
\hline 4 & 06893890 & $3 / 20 / 2013$ & -- & 13.0 & 8.4 & 446 & 5.8 & 22 & 0 & 6.07 & 1.37 & 3 & 1 & 3 & 3 & 10 & PBS \\
\hline 5 & 06893910 & $3 / 21 / 2007$ & & 11.2 & 7.9 & 538 & 11.2 & 34 & 5 & 6.31 & 2.38 & 3 & 3 & 3 & 5 & 14 & PBS \\
\hline 5 & 06893910 & $3 / 27 / 2008$ & & 12.4 & 7.9 & 485 & 7.7 & 36 & 7 & 6.30 & 2.43 & 3 & 3 & 3 & 5 & 14 & PBS \\
\hline 5 & 06893910 & $3 / 19 / 2009$ & & 15.8 & 7.8 & 489 & 9.3 & 41 & 7 & 6.30 & 2.65 & 5 & 3 & 3 & 5 & 16 & FBS \\
\hline 6 & 06893940 & $3 / 22 / 2007$ & -- & 8.9 & 7.1 & 807 & 13.8 & 31 & 5 & 6.66 & 2.66 & 3 & 3 & 3 & 5 & 14 & PBS \\
\hline 6 & 06893940 & $3 / 25 / 2008$ & -- & 14.2 & 7.8 & 820 & 8.0 & 30 & 4 & 6.00 & 2.37 & 3 & 1 & 3 & 5 & 12 & PBS \\
\hline 6 & 06893940 & $3 / 11 / 2011$ & -- & 11.4 & 7.4 & 808 & 4.9 & 31 & 4 & 6.40 & 2.54 & 3 & 1 & 3 & 5 & 12 & PBS \\
\hline 7 & 06893970 & $3 / 21 / 2007$ & & 11.0 & 8.0 & 873 & 11.6 & 26 & 4 & 7.26 & 2.37 & 3 & 1 & 3 & 5 & 12 & PBS \\
\hline 7 & 06893970 & $3 / 25 / 2008$ & & 15.1 & 7.9 & 846 & 7.4 & 28 & 4 & 6.85 & 2.30 & 3 & 1 & 3 & 5 & 12 & PBS \\
\hline 7 & 06893970 & 3/17/2009 & & -- & 7.8 & 832 & 10.2 & 32 & 7 & 6.29 & 2.51 & 3 & 3 & 3 & 5 & 14 & PBS \\
\hline 7 & 06893970 & $4 / 8 / 2010$ & 65 & 11.2 & 7.9 & 758 & 10.4 & -- & -- & -- & -- & -- & -- & -- & -- & -- & -- \\
\hline 7 & 06893970 & $3 / 10 / 2011$ & & 0.0 & 7.6 & 810 & 3.9 & 29 & 5 & 5.91 & 2.39 & 3 & 3 & 3 & 5 & 14 & PBS \\
\hline 7 & 06893970 & $3 / 19 / 2013$ & -- & 12.1 & 8.4 & 896 & 5.0 & 32 & 5 & 6.16 & 2.43 & 3 & 3 & 3 & 5 & 14 & PBS \\
\hline
\end{tabular}


Table 22. Habitat scores, dissolved oxygen, $\mathrm{pH}$, specific conductance, water temperature, macroinvertebrate metrics used in the stream condition index, and aquatic-life support status for samples collected March 2007 through March 2013.—Continued

[STAID, station identification number; $\mathrm{mg} / \mathrm{L}$, milligrams per liter; $\mu \mathrm{S}$ at $25^{\circ} \mathrm{C}$, microsiemens per centimeter at 25 degrees Celsius; RICH, total taxa richness; EPTR, Ephemeroptera-Plecoptera-Trichoptera taxa richness; MBI, Macroinvertebrate Biotic Index; SHANDIV, Shannon Diversity Index; SCI, stream condition index; ALS, aquatic-life support status; --, no data; PBS, partially biologically supporting; FBS, fully biologically supporting; NBS, nonbiologically supporting]

\begin{tabular}{|c|c|c|c|c|c|c|c|c|c|c|c|c|c|c|c|c|c|}
\hline $\begin{array}{c}\text { Site } \\
\text { number } \\
\text { (table 2; } \\
\text { fig. 1) }\end{array}$ & STAID & $\begin{array}{c}\text { Sample } \\
\text { collection } \\
\text { date }\end{array}$ & $\begin{array}{l}\text { Habitat } \\
\text { score }\end{array}$ & $\begin{array}{c}\text { Dissolved } \\
\text { oxygen } \\
\text { (mg/L) }\end{array}$ & $\begin{array}{c}\text { pH } \\
\text { (standard } \\
\text { units) }\end{array}$ & $\begin{array}{c}\text { Specific } \\
\text { conductance } \\
\left(\mu \mathrm{S} \text { at } 25^{\circ} \mathrm{C} \text { ) }\right.\end{array}$ & $\begin{array}{c}\text { Water } \\
\text { temperature } \\
\left({ }^{\circ} \mathrm{C}\right)\end{array}$ & RICH & EPTR & MBI & SHANDIV & $\begin{array}{l}\text { RICH } \\
\text { Score }\end{array}$ & $\begin{array}{l}\text { EPTR } \\
\text { Score }\end{array}$ & $\begin{array}{c}\text { MBI } \\
\text { Score }\end{array}$ & $\begin{array}{c}\text { SHANDIV } \\
\text { Score }\end{array}$ & SCI ${ }^{1}$ & $\begin{array}{c}\text { ALS } \\
\text { rating }{ }^{2}\end{array}$ \\
\hline \multicolumn{18}{|c|}{ Spring samples_-Continued } \\
\hline 8 & 06893990 & $4 / 16 / 2010$ & 75 & 9.1 & 8.0 & 544 & 16.3 & -- & -- & -- & -- & -- & -- & -- & -- & -- & -- \\
\hline 8 & 06893990 & $3 / 11 / 2011$ & -- & 12.2 & 7.6 & 685 & 5.3 & 40 & 9 & 5.98 & 2.51 & 5 & 3 & 3 & 5 & 16 & FBS \\
\hline 9 & 06894000 & $3 / 20 / 2007$ & & 10.0 & 8.0 & 535 & 11.3 & 34 & 10 & 6.19 & 2.16 & 3 & 5 & 3 & 3 & 14 & PBS \\
\hline 9 & 06894000 & $3 / 27 / 2008$ & & 12.4 & 7.8 & 523 & 7.7 & 32 & 9 & 5.89 & 2.55 & 3 & 3 & 3 & 5 & 14 & PBS \\
\hline 9 & 06894000 & $3 / 19 / 2009$ & & 15.3 & 7.7 & 543 & 10.2 & 29 & 10 & 5.82 & 2.70 & 3 & 5 & 3 & 5 & 16 & FBS \\
\hline 9 & 06894000 & $4 / 20 / 2010$ & 84 & 8.8 & 8.1 & 587 & 16.4 & -- & -- & -- & -- & -- & -- & -- & -- & -- & -- \\
\hline 9 & 06894000 & $3 / 16 / 2011$ & & 11.2 & 6.7 & 708 & 6.7 & 37 & 8 & 5.81 & 2.31 & 5 & 3 & 3 & 5 & 16 & FBS \\
\hline 9 & 06894000 & $3 / 18 / 2013$ & -- & 12.3 & 7.9 & 508 & 5.8 & 32 & 7 & 5.30 & 2.78 & 3 & 3 & 5 & 5 & 16 & FBS \\
\hline 12 & 06895090 & $3 / 22 / 2007$ & -- & 8.7 & 7.9 & 500 & 13.0 & 34 & 4 & 6.55 & 2.28 & 3 & 1 & 3 & 5 & 12 & PBS \\
\hline 12 & 06895090 & $3 / 26 / 2008$ & -- & 12.1 & 7.8 & 495 & 7.7 & 40 & 10 & 7.30 & 2.63 & 5 & 5 & 3 & 5 & 18 & FBS \\
\hline 12 & 06895090 & $4 / 13 / 2010$ & 89 & 8.6 & 7.8 & 514 & 17.1 & -- & -- & -- & -- & -- & -- & -- & -- & -- & -- \\
\hline 13 & 06921582 & $3 / 14 / 2007$ & 139 & 11.1 & 8.2 & 519 & 14.8 & 33 & 8 & 6.26 & 2.24 & 3 & 3 & 3 & 3 & 12 & PBS \\
\hline 13 & 06921582 & $3 / 14 / 2008$ & & 11.3 & 8.0 & 744 & 8.0 & 28 & 8 & 6.44 & 2.10 & 3 & 3 & 3 & 3 & 12 & PBS \\
\hline 13 & 06921582 & $3 / 23 / 2009$ & & 10.3 & 8.0 & 665 & 14.5 & 38 & 12 & 5.90 & 2.96 & 5 & 5 & 3 & 5 & 18 & FBS \\
\hline 13 & 06921582 & $4 / 14 / 2010$ & 132 & 11.3 & 7.8 & 531 & 17.5 & -- & -- & -- & -- & -- & -- & -- & -- & -- & -- \\
\hline 13 & 06921582 & $3 / 18 / 2011$ & -- & 9.1 & 7.7 & 456 & 12.3 & 32 & 8 & 6.28 & 2.53 & 3 & 3 & 3 & 5 & 14 & PBS \\
\hline \multicolumn{18}{|c|}{ Fall samples } \\
\hline 1 & 06893620 & $8 / 27 / 2008$ & 96 & 10.2 & 7.9 & 880 & 22.7 & -- & -- & -- & -- & -- & -- & -- & -- & -- & -- \\
\hline 1 & 06893620 & $9 / 23 / 2008$ & & 8.2 & 7.7 & 846 & 19.3 & 26 & 6 & 6.35 & 2.60 & 3 & 3 & 5 & 5 & 16 & FBS \\
\hline 1 & 06893620 & 9/17/2009 & & 7.9 & 7.6 & 812 & 19.1 & 28 & 7 & 6.02 & 2.54 & 3 & 3 & 5 & 5 & 16 & FBS \\
\hline 1 & 06893620 & $10 / 4 / 2010$ & 110 & 8.6 & 7.9 & 808 & 11.9 & 24 & 6 & 6.30 & 2.51 & 3 & 3 & 5 & 5 & 16 & FBS \\
\hline 1 & 06893620 & $9 / 12 / 2012$ & 112 & 6.3 & 7.4 & 628 & 19.7 & 26 & 6 & 6.32 & 2.42 & 3 & 3 & 5 & 5 & 16 & FBS \\
\hline 2 & 06893820 & $10 / 6 / 2010$ & 90 & 9.3 & 7.9 & 438 & 13.3 & 32 & 10 & 5.76 & 2.42 & 3 & 5 & 5 & 5 & 18 & FBS \\
\hline 2 & 06893820 & 9/13/2012 & 87 & 6.9 & -- & 457 & 20.7 & 33 & 13 & 5.50 & 2.34 & 3 & 5 & 5 & 3 & 16 & FBS \\
\hline 3 & 06893830 & $9 / 17 / 2009$ & & 7.0 & 7.5 & 469 & 22.5 & 23 & 3 & 5.66 & 1.81 & 3 & 1 & 5 & 3 & 12 & PBS \\
\hline 3 & 06893830 & $10 / 7 / 2010$ & 73 & 7.5 & 7.6 & 657 & 17.1 & 29 & 5 & 6.02 & 2.44 & 3 & 3 & 5 & 5 & 16 & FBS \\
\hline 3 & 06893830 & $9 / 18 / 2012$ & 94 & 5.8 & 7.5 & 616 & 17.0 & 32 & 8 & 5.25 & 2.31 & 3 & 3 & 5 & 3 & 14 & PBS \\
\hline 4 & 06893890 & $10 / 5 / 2010$ & -- & 6.8 & 7.8 & 365 & 19.3 & 28 & 6 & 7.63 & 2.50 & 3 & 3 & 3 & 5 & 14 & PBS \\
\hline
\end{tabular}


Table 22. Habitat scores, dissolved oxygen, pH, specific conductance, water temperature, macroinvertebrate metrics used in the stream condition index, and aquatic-life support status for samples collected March 2007 through March 2013.—Continued

[STAID, station identification number; $\mathrm{mg} / \mathrm{L}$, milligrams per liter; $\mu \mathrm{S}$ at $25^{\circ} \mathrm{C}$, microsiemens per centimeter at 25 degrees Celsius; RICH, total taxa richness; EPTR, Ephemeroptera-Plecoptera-Trichoptera taxa richness; MBI, Macroinvertebrate Biotic Index; SHANDIV, Shannon Diversity Index; SCI, stream condition index; ALS, aquatic-life support status; --, no data; PBS, partially biologically supporting; FBS, fully biologically supporting; NBS, nonbiologically supporting]

\begin{tabular}{|c|c|c|c|c|c|c|c|c|c|c|c|c|c|c|c|c|c|}
\hline $\begin{array}{c}\text { Site } \\
\text { number } \\
\text { (table 2; } \\
\text { fig. 1) }\end{array}$ & STAID & $\begin{array}{l}\text { Sample } \\
\text { collection } \\
\text { date }\end{array}$ & $\begin{array}{l}\text { Habitat } \\
\text { score }\end{array}$ & $\begin{array}{l}\text { Dissolved } \\
\text { oxygen } \\
\text { (mg/L) }\end{array}$ & $\begin{array}{c}\text { pH } \\
\text { (standard } \\
\text { units) }\end{array}$ & $\begin{array}{c}\text { Specific } \\
\text { conductance } \\
\left(\mu \mathrm{S} \text { at } 25^{\circ} \mathrm{C} \text { ) }\right.\end{array}$ & $\begin{array}{c}\text { Water } \\
\text { temperature } \\
\left({ }^{\circ} \mathrm{C}\right)\end{array}$ & RICH & EPTR & MBI & SHANDIV & $\begin{array}{l}\text { RICH } \\
\text { Score }\end{array}$ & $\begin{array}{l}\text { EPTR } \\
\text { Score }\end{array}$ & $\begin{array}{l}\text { MBI } \\
\text { Score }\end{array}$ & $\begin{array}{l}\text { SHANDIV } \\
\text { Score }\end{array}$ & SCI $^{1}$ & $\begin{array}{c}\text { ALS } \\
\text { rating }^{2}\end{array}$ \\
\hline \multicolumn{18}{|c|}{ Fall samples-Continued } \\
\hline 4 & 06893890 & $9 / 13 / 2012$ & 66 & 5.4 & 7.2 & 479 & 18.2 & 30 & 5 & 6.96 & 2.21 & 3 & 3 & 3 & 3 & 12 & PBS \\
\hline 5 & 06893910 & $9 / 2 / 2008$ & 88 & 6.2 & 7.9 & 465 & 25.6 & -- & -- & -- & -- & -- & -- & -- & -- & -- & -- \\
\hline 5 & 06893910 & $9 / 26 / 2008$ & -- & 6.8 & 7.7 & 413 & 21.6 & 24 & 8 & 5.93 & 2.21 & 3 & 3 & 5 & 3 & 14 & PBS \\
\hline 5 & 06893910 & $9 / 15 / 2009$ & -- & 9.4 & 7.6 & 395 & 22.1 & 22 & 9 & 5.05 & 2.03 & 3 & 3 & 5 & 3 & 14 & PBS \\
\hline 5 & 06893910 & $10 / 6 / 2010$ & 88 & 8.3 & 7.8 & 427 & 15.7 & 27 & 9 & 5.58 & 2.02 & 3 & 3 & 5 & 3 & 14 & PBS \\
\hline 6 & 06893940 & $9 / 25 / 2008$ & -- & 7.3 & 7.6 & 743 & 19.6 & 25 & 5 & 6.56 & 2.63 & 3 & 3 & 3 & 5 & 14 & PBS \\
\hline 6 & 06893940 & $9 / 18 / 2012$ & 77 & 6.4 & 8.0 & 791 & 17.1 & 33 & 6 & 5.35 & 1.91 & 3 & 3 & 5 & 3 & 14 & PBS \\
\hline 7 & 06893970 & $8 / 26 / 2008$ & 97 & 9.1 & 8.1 & 789 & 21.9 & -- & -- & -- & -- & -- & -- & -- & -- & -- & -- \\
\hline 7 & 06893970 & $9 / 23 / 2008$ & -- & 8.0 & 7.6 & 833 & 18.7 & 29 & 7 & 6.69 & 2.46 & 3 & 3 & 3 & 5 & 14 & PBS \\
\hline 7 & 06893970 & $9 / 16 / 2009$ & -- & 11.8 & 7.8 & 814 & 20.2 & 24 & 5 & 6.98 & 2.16 & 3 & 3 & 3 & 3 & 12 & PBS \\
\hline 7 & 06893970 & $10 / 7 / 2010$ & 65 & 8.4 & 8.0 & 787 & 13.7 & 29 & 8 & 6.29 & 2.41 & 3 & 3 & 5 & 5 & 16 & FBS \\
\hline 7 & 06893970 & $9 / 17 / 2012$ & 108 & 7.6 & 7.5 & 597 & 17.7 & 32 & 4 & 7.82 & 2.44 & 3 & 1 & 3 & 5 & 12 & PBS \\
\hline 8 & 06893990 & $10 / 4 / 2010$ & -- & 9.2 & 7.9 & 638 & 11.3 & 22 & 6 & 6.68 & 1.89 & 3 & 3 & 3 & 3 & 12 & PBS \\
\hline 9 & 06894000 & $9 / 2 / 2008$ & 90 & 5.8 & 7.8 & 492 & 25.6 & -- & -- & -- & -- & -- & -- & -- & -- & -- & -- \\
\hline 9 & 06894000 & 9/26/2008 & -- & 7.7 & 7.7 & 452 & 21.3 & 29 & 10 & 6.18 & 1.76 & 3 & 5 & 5 & 3 & 16 & FBS \\
\hline 9 & 06894000 & $9 / 15 / 2009$ & -- & 8.1 & 7.7 & 431 & 22.3 & 19 & 7 & 5.67 & 1.98 & 3 & 3 & 5 & 3 & 14 & PBS \\
\hline 9 & 06894000 & $10 / 5 / 2010$ & 84 & 9.0 & 8.0 & 466 & 15.4 & 36 & 11 & 5.90 & 2.67 & 3 & 5 & 5 & 5 & 18 & FBS \\
\hline 9 & 06894000 & 9/12/2012 & 95 & 7.0 & 7.7 & 551 & 22.6 & 26 & 9 & 5.89 & 1.91 & 3 & 3 & 5 & 3 & 14 & PBS \\
\hline 10 & 390259094201201 & 9/19/2012 & 77 & 8.6 & 7.4 & 528 & 18.2 & 33 & 10 & 6.37 & 2.75 & 3 & 5 & 5 & 5 & 18 & FBS \\
\hline 12 & 06895090 & $8 / 28 / 2008$ & 86 & 6.0 & 7.6 & 565 & 25.2 & -- & -- & -- & -- & -- & -- & -- & -- & -- & -- \\
\hline 12 & 06895090 & $9 / 24 / 2008$ & -- & 7.6 & 7.8 & 551 & 19.4 & 16 & 4 & 7.89 & 1.86 & 1 & 1 & 3 & 3 & 8 & NBS \\
\hline 12 & 06895090 & 9/16/2009 & -- & 9.3 & 7.5 & 550 & 20.2 & 24 & 5 & 6.80 & 2.14 & 3 & 3 & 3 & 3 & 12 & PBS \\
\hline 13 & 06921582 & $9 / 3 / 2008$ & 116 & 5.5 & -- & 948 & 22.3 & -- & -- & -- & -- & -- & -- & -- & -- & -- & -- \\
\hline 13 & 06921582 & $9 / 25 / 2008$ & -- & 7.8 & 7.9 & 710 & 19.8 & 30 & 11 & 6.22 & 2.20 & 3 & 5 & 5 & 3 & 16 & FBS \\
\hline 13 & 06921582 & $9 / 18 / 2009$ & -- & 8.5 & 7.7 & 601 & 19.6 & 33 & 12 & 6.08 & 2.03 & 3 & 5 & 5 & 3 & 16 & FBS \\
\hline 13 & 06921582 & $10 / 1 / 2010$ & 132 & 7.2 & 7.9 & 546 & 17.3 & 22 & 7 & 6.03 & 1.77 & 3 & 3 & 5 & 3 & 14 & PBS \\
\hline 13 & 06921582 & $9 / 14 / 2012$ & 123 & 6.8 & 8.1 & 481 & 18.1 & 31 & 6 & 6.35 & 2.58 & 3 & 3 & 5 & 5 & 16 & FBS \\
\hline
\end{tabular}

${ }^{1}$ The SCI is the sum of the RICH, EPTR, MBI, and SHANDIV scores.

${ }^{2}$ The ALS rating is based on the SCI. A score of 8 or less is NBS, a score of 10 to 14 is PBS, and a score of 16 to 20 is FBS. 


\section{Summary}

The U.S. Geological Survey (USGS) and the City of Independence, Missouri, Water Pollution Control (WPC) Department began a cooperative study in June 2005 to characterize and evaluate the water quality and ecological condition of urban streams within Independence. Continuous streamflow, physical and chemical properties, total dissolved solids (TDS), sodium, chloride, nutrients, total recoverable metals, dissolved mercury, common organic micro-constituents (OMCs), pesticides in streambed sediment and surface water, fecal indicator bacteria (FIB; Escherichia coli, fecal coliform, total coliform), microbial source tracking (MST), and suspended sediment concentration (SSC) data were collected and analyzed in base-flow and stormflow samples. Annual loads were calculated using these data to characterize contaminant sources to Independence receiving streams and their contributions to the Little Blue River, beginning June 2005 through September 2013. Annual loads were estimated for TDS, chloride, total nitrogen and select other nitrogen species, total phosphorus, Escherichia coli (E. coli), and SSC by using regression models. Annual dry-weather screenings were done beginning in water year (WY; time period from October 1 of the previous year to September 30 of the current year) 2006 in most basins in Independence to identify any point source discharges containing possible contaminants.

Continuous streamflow data were collected and automatic samplers were installed at eight sites; three sites on the Little Blue River (site 2, Little Blue River at Lee's Summit Road; site 5, Little Blue River at 39th Street; and site 9, Little Blue River near Lake City) and five smaller streams in Independence (site 1, Rock Creek; site 3, Adair Creek; site 4, East Fork Little Blue River; site 6, Crackerneck Creek; and site 7, Spring Branch Creek). Two ungaged sites on smaller streams also were sampled for base-flow and stormflow water quality: site 8, Burr Oak Creek; and site 11, Bundschu Creek. Two comparison sites were selected as control sites for habitat assessment and benthic macroinvertebrate samples: site 12, East Fork Crooked River; and site 13, South Grand River. One additional ungaged site within Independence (site 10, Cut-off meander near Lake City) also was selected for benthic macroinvertebrate sampling and habitat assessment. The summary sites will hereafter be referred to by site number (1 through 13). Water-surface elevation (stage) data were measured in 15-minute intervals and used to compute streamflow records. Streamflow measurements were made at all sampling sites at regular intervals.

Seven sites (sites 1 through 5, 7, and 9) were equipped with continuous water-quality monitors (CWQMs) either for part or all of the study period. Dissolved oxygen, $\mathrm{pH}$, specific conductance, water temperature, and turbidity were recorded in 15-minute intervals. Daily average dissolved oxygen values were at or below the Missouri standard for protection of aquatic life (AQL) less than 1 percent of the time on the Little Blue River (sites 2, 5, and 9) to as much as 10 percent of the time at site 4. No daily values of $\mathrm{pH}$ recorded in Independence streams were outside the Missouri AQL range. Daily $\mathrm{pH}$ values ranged between 6.9 standard units to 8.4 standard units. The daily average specific conductance values for Independence streams ranged between 221 microsiemens per centimeter $(\mu \mathrm{S} / \mathrm{cm})$ to $3,680 \mu \mathrm{S} / \mathrm{cm}$, and were generally higher on the smaller streams (sites 1, 3, and 7) than on the Little Blue River (sites 2, 5, and 9). The Missouri AQL standard for water temperature in streams was exceeded less than 1 percent of the time in Independence streams. The daily average water temperature values recorded at sites with CWQMs ranged from -0.2 degrees Celsius $\left({ }^{\circ} \mathrm{C}\right)$ to $32.4{ }^{\circ} \mathrm{C}$. Daily average turbidity exceeded the U.S. Environmental Protection Agency (EPA) recommended guideline between 15 and 60 percent of the time, and site 2 had both the minimum ( 0.0 NTU) and maximum (1,054 NTU) recorded daily turbidity value of all the sites.

From June 2005 to September 2013, there were a total of 175 base-flow and 205 stormflow water-quality samples collected at 10 sites in Independence (sites 1 through 9, and 11). Most of the base-flow samples were split between the spring and early summer season (73 samples) and the winter season (71 samples), with the remainder (31 samples) collected during the fall transitional season. The stormflow samples were primarily collected during the early summer season (80 samples), with the remaining samples split between the winter season (66 samples) and the fall transitional season (59 samples).

Base-flow and stormflow measurements of physical and chemical properties in Independence streams varied within the normal range for environmental waters. The minimum and maximum measured TDS in base flow (187 milligrams per liter $[\mathrm{mg} / \mathrm{L}]$ to $1,190 \mathrm{mg} / \mathrm{L}$ ) was similar to that of stormflow $(61 \mathrm{mg} / \mathrm{L}$ to $1,200 \mathrm{mg} / \mathrm{L})$. Most of the smaller streams (sites 1, 3 , and 6 through 8) had higher median base-flow TDS concentrations than the Little Blue River sites (sites 2, 5, and 9), but median stormflow TDS concentrations were similar among all sites. The median TDS value for all stormflow samples $(221 \mathrm{mg} / \mathrm{L})$ was less than that of all base-flow samples $(441 \mathrm{mg} / \mathrm{L})$. Measured chloride concentrations in base flow ranged from $16.9 \mathrm{mg} / \mathrm{L}$ to $459 \mathrm{mg} / \mathrm{L}$, and stormflow ranged from $3.4 \mathrm{mg} / \mathrm{L}$ to $508 \mathrm{mg} / \mathrm{L}$. Fifteen base-flow samples and 11 stormflow samples had measured chloride concentrations greater than the Missouri chronic standard for AQL, but none exceeded the Missouri acute standard for AQL. There were eight total recoverable metals (unfiltered sample that includes dissolved and suspended material) analyzed in base-flow and stormflow samples: aluminum, cadmium, chromium, copper, lead, zinc, arsenic, and dissolved mercury. Concentrations of aluminum were highest in both base-flow and stormflow samples, and ranged from 7 micrograms per liter $(\mu \mathrm{g} / \mathrm{L})$ to $1,420 \mu \mathrm{g} / \mathrm{L}$ in base-flow samples and from $8.5 \mu \mathrm{g} / \mathrm{L}$ to $170,000 \mu \mathrm{g} / \mathrm{L}$ in stormflow samples. Most total recoverable metals concentrations were generally less than the Missouri AQL for dissolved metals.

Daily average streamflow, estimated annual load, and estimated annual flow-weighted concentrations were computed 
for select constituents (TDS, chloride, select nutrient constituents, E. coli, and SSC) measured at each Independence site (sites 1 through 9). The highest estimated annual load of TDS was 72,600 megagrams (Mg) in WY 2010 and the highest estimated annual flow-weighted concentration of TDS was $1,123 \mathrm{mg} / \mathrm{L}$ in WY 2006. The highest estimated annual chloride load was 14,100 Mg in WY 2010 and the highest estimated annual flow-weighted concentration for chloride was $152 \mathrm{mg} / \mathrm{L}$ in WY 2013. The median total nitrogen (N) concentrations measured in base flow ranged from $0.5 \mathrm{mg} / \mathrm{L}$ to $2.2 \mathrm{mg} / \mathrm{L}$, and from $1.2 \mathrm{mg} / \mathrm{L}$ to $3.2 \mathrm{mg} / \mathrm{L}$ in stormflow. Median total phosphorus $(\mathrm{P})$ concentrations ranged from $0.045 \mathrm{mg} / \mathrm{L}$ to $0.152 \mathrm{mg} / \mathrm{L}$ in base flow, and from $0.04 \mathrm{mg} / \mathrm{L}$ to $1.29 \mathrm{mg} / \mathrm{L}$ in stormflow. The median total organic $\mathrm{N}$ and nitrate concentrations accounted for 84 percent of the median total $\mathrm{N}$ concentration in base-flow samples and 98 percent in stormflow samples. Median dissolved $\mathrm{P}$ accounted for 68 percent of the median total $\mathrm{P}$ concentration in base-flow samples and 13 percent in stormflow samples. Total $\mathrm{N}$ concentrations exceeded the EPA provisional nutrient standard in 52 percent of base flow and 93 percent of stormflow samples in the smaller streams (sites 1, 3, 4, 6 through 8), and 24 percent of base-flow and 92 percent of stormflow samples at the Little Blue River sites (sites 2, 5, and 9). Total P concentrations exceeded the EPA provisional nutrient standard in 48 percent of base-flow and 94 percent of stormflow samples on the smaller streams, and in 30 percent of base-flow and 97 percent of stormflow samples on the Little Blue River (sites 2, 5 and 9).

There were 71 base-flow samples and 130 stormflow samples from June 2005 to September 2013 that were analyzed for 11 categories of OMCs. Four categories (polyaromatic hydrocarbons [PAHs] and combustion products, pesticides, plastics, and sterols and stanols) were detected in at least 50 percent of base-flow samples, and the same four categories along with stimulants were detected in greater than 90 percent of stormflow samples. The overall median concentration of OMCs in all base-flow samples was $0.06 \mu \mathrm{g} / \mathrm{L}$, and in all stormflow samples was $0.13 \mu \mathrm{g} / \mathrm{L}$. The highest maximum concentration of OMCs in base flow measured at each site $(53.3 \mu \mathrm{g} / \mathrm{L})$ was higher than that of stormflow $(26.4 \mu \mathrm{g} / \mathrm{L})$. All stormflow samples had at least one quantified detection of at least one OMC compound.

Fourteen base-flow samples were analyzed for pesticides in streambed sediment. One-half of the analyzed constituents (11 of 22) had detections in one or more samples. Two baseflow samples and 17 stormflow samples were also analyzed for pesticides in surface water. Twenty-six constituents were analyzed, but none were detected in any base-flow or stormflow samples.

FIB were analyzed in 159 base-flow samples and 168 stormflow samples collected from June 2005 to September 2013. Median E. coli densities in base flow ranged from 19 most probable number per 100 milliliters (MPN/100 mL) to $410 \mathrm{MPN} / 100 \mathrm{~mL}$, and in stormflow from 1,200 MPN/100 mL to $31,000 \mathrm{MPN} / 100 \mathrm{~mL}$. Median fecal coliform densities in base flow ranged from 4 colonies per 100 milliliters (col/100 $\mathrm{mL}$ ) to $530 \mathrm{col} / 100 \mathrm{~mL}$, and in stormflow from $960 \mathrm{col} / 100$ $\mathrm{mL}$ to $42,000 \mathrm{col} / 100 \mathrm{~mL}$. Median total coliform densities in base flow ranged from $2,950 \mathrm{MPN} / 100 \mathrm{~mL}$ to $33,000 \mathrm{MPN} / 100 \mathrm{~mL}$, and in stormflow from 57,000 MPN/100 mL to $1,190,000 \mathrm{MPN} / 100 \mathrm{~mL}$. The Little Blue River sites (sites 2, 5, and 9) tended to have lower median FIB densities in both base-flow and stormflow than those measured on most of the smaller streams (sites 1, 6 through 8, and 11). The median SSC concentration for base-flow samples ranged from $13 \mathrm{mg} / \mathrm{L}$ to $63 \mathrm{mg} / \mathrm{L}$ and for stormflow from $66 \mathrm{mg} / \mathrm{L}$ to $1,130 \mathrm{mg} / \mathrm{L}$, and was generally lower on the Little Blue River sites than on most of the smaller streams (sites 1, 6 through 8 , and 11) during base flow, and mid-range for the Little Blue River sites between those measured in sites 1, 3, 6, and 7 during stormflow.

The highest estimated annual load of $E$. coli was $168,000,000$ billion colonies and the highest estimated annual flow-weighted concentration of $E$. coli was 96,303 billion colonies.. The highest estimated annual SSC load was $808,000 \mathrm{Mg}$, and the highest estimated annual flow-weighted concentration of SSC was $4,479 \mathrm{mg} / \mathrm{L}$.

E. coli and MST markers were analyzed using libraryindependent methods in 119 base-flow, 89 stormflow, and 4 snowmelt samples from June 2008 through September 2013. MST samples were collected at 10 sites (sites 1 through 9 and 11). In addition, 48 fecal source samples were collected between September 2011 and May 2013 from human, ruminant, dog, and several domestic and wild animal sources (cat, chicken, cow, deer, goose, horse, mouse, rabbit, and wild turkey). Twelve sewage influent samples also were collected from September 2011 through May 2013.

E. coli were detected in 112 of 119 base-flow samples ( $E$. coli was not analyzed in 5 samples), all 89 stormflow samples, and all 4 snowmelt samples, for which MST markers also were analyzed. During the recreation season, about 45 percent of base-flow samples and about 98 percent of stormflow samples exceeded the Missouri standard for E. coli. E. coli and hostsource bacteria (human, canine, and ruminant) as determined by MST were detected more frequently and at higher concentrations during stormflow. Most of the estimated E. coli loads occur during stormflow.

Dry-weather screening was done by the USGS and Independence WPC Department personnel during WYs 2006 through 2013 in most basins within the city limits. Any measureable inflow, discharge, or tributary flow to the selected stream was sampled. Two basins (Rock Creek and Spring Branch Creek) were sampled four times, one (Adair Creek) was sampled three times, and the remaining eight basins (Crackerneck, Mill, Sugar, Bundschu, Burr Oak, and West Fire Prairie Creeks, and East Fork Little Blue and Little Blue Rivers) were sampled one or two times. A total of 1,052 samples were collected from area stream basins for analysis of total chlorine, total dissolved copper, phenols, and anionic surfactants. Eight detections were determined to have a source such as a straight pipe discharge or broken water/septic line and 
corrective action was taken by Independence WPC. About 207 (19.7 percent) of samples were at or above a defined standard or guideline for each of the constituents. A total of 73 samples were above the standard for total chlorine, 1 sample was above the standard for phenols, and 133 samples were above the guideline for anionic surfactants. No Federal or State standard has been determined for dissolved copper in unfiltered (total) samples.

Individual macroinvertebrate metric values varied substantially by site and year; however, seasonal median stream condition index (SCI) scores for all Independence sites combined were the same despite some variability in component metrics. SCI scores indicated that 20 percent of spring Independence stream site samples met the criteria for full support of aquatic life and 80 percent were considered partially supportive, whereas 42 percent of fall samples were considered fully biologically supporting and 58 percent partially biologically supporting. No Independence stream sample had a non-supporting score.

This report presents all publishable data collected from June 2005 to September 2013 in streams and basins within the city limits of Independence, Missouri. The streamflow, waterquality, and ecological data collected during this study fulfill the municipal separate sewer system permit requirements for Independence and can be used to provide a baseline to determine the effectiveness of current (2014) and future best management practices within Independence.

\section{References Cited}

Adolphson, D.L., Arnold, T.L., Fitzpatrick, F.A., Harris, M.A., Richards, K.D., Scudder, B.C., and Stewart, J.S., 2001, Physical, chemical, and biological methods and data from the urban land-use-gradient study, Des Plaines and Fox River Basins, Illinois, 1999-2001: U.S. Geological Survey Open-File Report 01-459, 20 p.

Applied Maths NV, 2014, BioNumerics-The universal platform for databasing and analysis of all biological data: brochure, 16 p., accessed June 2014 at http://download. applied-maths.com/sites/default/files/download/brochure_ bn.pdf.

Arar, E.J., and Collins, G.B., 1997, U.S. Environmental Protection Agency Method 445.0, In vitro determination of chlorophyll a and pheophytin a in marine and freshwater algae by fluorescence, Revision 1.2: Cincinnati, Ohio, U.S. Environmental Protection Agency, National Exposure Research Laboratory, Office of Research and Development, $22 \mathrm{p}$.
Barbour, M.T., Gerritsen, J., Snyder, B.D., and Stribling, J.B., 1999, Rapid bioassessment protocols for use in streams and wadeable rivers-Periphyton, benthic Macroinvertebrates and fish (2d ed.): Washington, D.C., U.S. Environmental Protection Agency EPA 841-B-99-002, Office of Water, $322 \mathrm{p}$.

Blocksom, K.A., and Winters, L., 2006, The evaluation of methods for creating defensible, repeatable, objective and accurate tolerance values for aquatic taxa: Cincinnati, Ohio, U.S. Environmental Protection Agency, Office of Research and Development, National Exposure Research Laboratory, $52 \mathrm{p}$.

Bode, R.W., Novak, M.A., Abele, L.E., Heitzman, D.L., and Smith, A.J., 2002, Quality assurance work plan for biological stream monitoring in New York State: Albany, New York, New York State Department of Environmental Conservation, $122 \mathrm{p}$.

Carson, A.C., Christiansen, J.M., Yampara-Iquise, H., Benson, V.W., Baffaut, C., Davis, J.V., Broz, R.R., Kurtz, W.B., Rogers, W.M., and Fales, W.H., 2005, Specificity of a Bacteroides thetaiotaomicron marker for human feces: Applied and Environmental Microbiology, v. 71, no. 8, p. 4945-4949.

Carson, A.C., Shear, B.L., Ellershieck, M.R., and Asfaw, A., 2001, Identification of fecal Escherichia coli from humans and animals by ribotyping: Applied and Environmental Microbiology, v. 67, p. 1503-1507.

Carson, A.C., Shear, B.L., Ellershieck, M.R., and Schnell, J.D., 2003, Comparison of ribotyping and repetitive extragenic palindronic-PCR for identification of fecal Escherichia coli from humans and animals: Applied and Environmental Microbiology, v. 69, p. 1836-1839.

CHEMetrics, Incorporated, 2013, Technical Data Sheet, Phenols, 4-Aminoantipyrine Method: accessed June 2014 at http://www.chemetrics.com/products/pdf/phenols.pdf.

Childress, C.J.O., Foreman, W.T., Connor, B.F., and Maloney, T.J., 1999, New reporting procedures based on longterm method detection levels and some considerations for interpretations of water-quality data provided by the U.S. Geological Survey National Water Quality Laboratory: U.S. Geological Survey Open-File Report 99-193, 19 p., accessed June 2014 at $h t t p: / / w a t e r . u s g s . g o v / o w q / O F R \_99-$ 193/index.html.

Christensen, E.D., Harris, T.E., and Niesen, S.L., 2010, Water quality and ecological condition of urban streams in Independence, Missouri, June 2005 through December 2008: U.S. Geological Survey Scientific Investigations Report 2010-5074, 113 p. 
Christensen, E.D., and Krempa, H.M., 2012, Assessment of macroinvertebrate communities in adjacent urban stream basins, Kansas City, Missouri, metropolitan area, 2007 through 2011: U.S. Geological Survey Scientific Investigations Report 2012-5284, 45 p. and tables.

Cuffney, T.F., Bilger, M.D., and Haigler, A.M., 2007, Ambiguous taxa-Effects on the characterization and interpretation of invertebrate assemblages: Journal of the North American Benthological Society, v. 26, no. 2, p. 286-307.

Cuffney, T.F., Brightbill, R.A., May, J.T., and Waite, I.R., 2010, Responses of benthic macroinvertebrates to environmental changes associated with urbanization in nine metropolitan areas: Ecological Applications, v. 20, p. 1384-1401.

Cuffney, T.F., and Brightbill, R.A., 2011, User's manual for the National Water-Quality Assessment Program Invertebrate Data Analysis System (IDAS) software, version 5: U.S. Geological Survey Techniques and Methods, book 7, chap. C4, 126 p., accessed December 2014 at http://pubs. usgs.gov/tm/7c4/.

Cummings, K.S. and Graf, D.L., 2010, Mollusca: Bivalvia, in Thorp, J.H. and Covich, A.P., eds., Ecology and classification of North American freshwater invertebrates (3rd ed.): Academic Press, San Diego, California, p. 309-384.

Dombek, P.E., Johnson, L.K., Zimmerley, S.T., and Sadowsky, M.J., 2000, Use of repetitive DNA sequences and the PCR to differentiate Escherichia coli isolates from human and animal sources: Applied and Environmental Microbiology, v. 66, p. $2572-2577$.

Electronic Code of Federal Regulations, 2013, Protection of environment-EPA Administered Permit Programs-The National Pollutant Discharge Elimination System 122.26(b) (8): accessed June 2014 at http://www.gpo.gov/fdsys/pkg/ CFR-2013-title40-vol23/xml/CFR-2013-title40-vol23sec122-26.xml.

Fishman, M.J., ed., 1993, Methods of analysis by the U.S. Geological Survey National Water Quality LaboratoryDetermination of inorganic and organic constituents in water and fluvial sediments: U.S. Geological Survey OpenFile Report 93-125, 217 p.

Fishman, M.J., and Friedman, L.C., 1989, Methods for determination of inorganic substances in water and fluvial sediments: U.S. Geological Survey Techniques of WaterResources Investigations, book 5, chap. A1, 545 p.

Garbarino, J.R., and Damrau, D.L., 2001, Methods of analysis by the U.S. Geological Survey National Water Quality Laboratory; determination of organic plus inorganic mercury in filtered and unfiltered natural water with cold vapor; atomic fluorescence spectrometry: U.S. Geological Survey WaterResources Investigations Report 01-4132, 16 p.
Garbarino, J.R., Kanagy, L.K., and Cree, M.E., 2006, Determination of elements in natural-water, biota, sediment and soil samples using collision/reaction cell inductively coupled plasma-mass spectrometry: U.S. Geological Survey Techniques and Methods, book 5, chap. B1, 88 p.

Garbarino, J.R., and Struzeski, T.M., 1998, Methods of analysis by the U.S. Geological Survey National Water Quality Laboratory; determination of elements in whole-water digests using inductively coupled plasma; optical emission spectrometry and inductively coupled plasma-mass spectrometry: U.S. Geological Survey Open-File Report 98-165, $101 \mathrm{p}$.

Govedich, F.R., Bain, B.A., Moser, W.E., Gelder, S.R., Davies, R.W., and Brinkhurst, R.O., 2010, Annelida (Clitellata): Oligochaeta, Branchiobdellida, Hirudinida, and Acanthobdellida, in Thorp, J.H. and Covich, A.P., eds., Ecology and classification of North American freshwater invertebrates (3rd ed.): Academic Press, San Diego, California, p. 385-436.

Grotheer, S.A., Moulton, S.R., Carter, J.L., Cuffney, T.F., and Short, T.M., 2000, Quality-control of benthic macroinvertebrate identifications - A taxon-based approach, in North American Benthological Society Annual Meeting, Keystone Colorado, 2000, Abstracts: accessed July 2009 at http:// www. benthos.org/meeting/nabs2000/nabstracts2000.cfm/ id/233.

Guy, H.P., 1969, Laboratory theory and methods for sediment analysis: U.S. Geological Survey Techniques of WaterResources Investigations, book 5, chap. C1, 58 p.

Hach Company, 2004, DR/2400 spectrophotometer procedure manual: accessed June 2014, at http://www.hach.com/ dr-2400-portable-spectrophotometer-115-vac/product-down loads? $i d=7640439018 \&$ callback $=q s$.

Heimann, D.C., 1995, Physical, chemical, and biological characteristics of three reservoirs in west-central Missouri, 1991-93: U.S. Geological Survey Water-Resources Investigations Report 95-4120, 114 p.

Hem, J.D., 1992, Study and interpretation of chemical characteristics of natural water (3d ed): U.S. Geological Survey Water-Supply Paper 2254, 263 p.

Hilsenhoff, W.L., 1977, Use of arthropods to evaluate water quality of streams: Technical Bulletin, Wisconsin Department of Natural Resources, no. 100, p. 15.

Hilsenhoff, W.L., 1988, Rapid field assessment of organic pollution with a family-level biotic index: Journal of the North American Benthological Society, v. 7, p. 65-68. 
Hoffman, G.L., Fishman, M.J., and Garbarino, J.R., 1996, Methods of analysis by the U.S. Geological Survey National Water Quality Laboratory-In-bottle acid digestion of whole-water samples: U.S. Geological Survey Open-File Report 96-225, $28 \mathrm{p}$.

Huggins, D.G., and Moffett, M.F., 1988, Proposed biotic and habitat indices for use in Kansas streams: Lawrence, Kansas, Kansas Biological Survey Report No. 35, p. 128.

IDEXX Laboratories, 2009, Quanti-Tray procedure: accessed June 2014 at $h t t p: / / w w w . i d e x x . c o m / p u b w e b r e s o u r c e s / p d f /$ en_us/water/0602030.pdf.

Klemm, D.J., Blocksom, K.A., Thoeny, W.T., Fulk, F.A., Herlihy, A.T., Kaufmann, P.R., and Cormier, S.M., 2002, Methods development and use of macroinvertebrates as indicators of ecological conditions for streams in the MidAtlantic Highlands Region: Environmental Monitoring and Assessment, v. 78, p. 169-212.

Kildare, B.J., Leutenegger, C.M., McSwain, B.S., Bambic, D.G., Rajal, V.B., and Wuertz, S., 2007, 16S rRNA-based assays for quantitative detection of universal, human-, cow-, and dog-specific fecal Bacteroidales-A Bayesian approach: Water research, v. 41, no. 16, p. 3701-3715.

Kolpin, D.W., Furlong, E.T., Meyer, M.T., Thurman, E.M., Zaugg, S.D., Barber, L.B., and Buxton, H.T., 2002, Pharmaceuticals, hormones, and other organic wastewater contaminants in U.S. streams, 1999-2000-A national reconnaissance: Environmental Science and Technology, v. 36, p. $1202-1211$.

Layton, A., McKay, L., Williams, D., Garrett, V., Gentry, R., and Sayler, G., 2006, Development of Bacteroides 16S rRNA gene TaqMan-based real-time PCR assays for estimation of total, human, and bovine fecal pollution in water: Applied and Environmental Microbiology, v. 72, no. 6, p. 4214-4224.

Lee, C.J., Mau, D.P., and Rasmussen, T.J., 2005, Effects of nonpoint and selected point contamination sources on stream-water quality and relation to land use in Johnson County, northeastern Kansas, October 2002 through June 2004: U.S. Geological Survey Scientific Investigations Report 05-5144, $104 \mathrm{p}$.

Lee, K.E., Barber, L.B., Furlong, E.T., Cahill, J.D., Kolpin, D.W., Meyer, M.T., and Zaugg, S.D., 2004, Presence and distribution of organic wastewater compounds in wastewater, surface, ground, and drinking waters, Minnesota, 2000-02: U.S. Geological Survey Scientific Investigations Report 04-5138, $47 \mathrm{p}$.

Lenat, D.R., 1993, A biotic index for the southeastern United States-Derivation and list of tolerance values, with criteria for assigning water quality ratings: Journal of the North American Benthological Society, v. 12, no. 3, p. 279-290.
Maloney, T.J., ed., 2005, Quality management system, U.S. Geological Survey National Water Quality Laboratory: U.S. Geological Survey Open-File Report 2005-1263, version 1.3 , chapters and appendixes variously paged, accessed June 2014 at http://pubs.usgs.gov/of/2005/1263/.

Mid-America Regional Council and F.X. Browne Associates, Incorporated, 1983, Nationwide Urban Runoff ProgramKansas City Area Project, Technical Report, 242 p.

Missouri Department of Natural Resources, 2006, Missouri's water pollution control permits manual, accessed June 2014 at http://www.dnr.mo.gov/env/wpp/permits/manual/permitmanual.htm.

Missouri Department of Natural Resources, 2014a, Water quality, chap. 7 of Rules of Department of Natural Resources, Division 20- Clean Water Commission: 10 CSR 20-7), p. 1-48, accessed December 2014, at http://www.sos. mo.gov/adrules/csr/current/10csr/10c20-7b.pdf.

Missouri Department of Natural Resources, 2014b, Water quality, chap. 7 of Rules of Department of Natural Resources, Division 20-Clean Water Commission: 10 CSR 20-7, p. 49-151, accessed December 2014, at https://www. sos.mo.gov/adrules/csr/current/10csr/10c20-7a.pdf.

Moulton, S.R., II, Carter, J.L., Grotheer, S.A., Cuffney, T.S., and Short, T.M., 2000, Methods of analysis by the U.S. Geological Survey National Water Quality LaboratoryProcessing, taxonomy, and quality control of benthic macroinvertebrates samples: U.S. Geological Survey Open-File Report 00-212, 49 p.

Moulton, S.R., II, Kennen, J.G., Goldstein, R.M., and Hambrook, J.A., 2002, Revised protocols for sampling algal, invertebrate, and fish communities as part of the National Water-Quality Assessment Program: U.S. Geological Survey Open-File Report 02-150, 75 p.

Mueller, D.S., Wagner, C.R., Rehmel, M.S., Oberg, K.A., and Rainville, Francois, 2013, Measuring discharge with acoustic Doppler current profilers from a moving boat (ver. 2.0, December 2013): U.S. Geological Survey Techniques and Methods, book 3, chap. A22, 95 p., accessed June 2014 http://pubs.usgs.gov/tm/3a22/.

Musolff, A., Leschik, S., Möder, M., Strauch, G., Reinstorf, F., and Schirmer, F., 2009, Temporal and spatial patterns of micropollutants in urban receiving waters: Environmental Pollution, v. 157, no. 11, p. 3069-3077, accessed June 2014 at http://www.sciencedirect.com/science/article/pii/ S0269749109002619.

National Climatic Data Center, 2014a, Record of climatological observations, 1884-2013: accessed June 2014 at $h t t p: / /$ www.ncdc.noaa.gov/IPS/cd/cd.html;jsessionid $=0 D F A 31 D C$ 80F18CC294FBFC25EA49202A. 
National Climatic Data Center, 2014b, Data Tools: 1981-2010 Normals: accessed July 2014 at $h t t p: / / w w w . n c d c . n o a a . g o v /$ cdo-web/datatools/normals.

Noriega, M.C., Wydoski, D.S., and Foreman, W.T., 2004, Methods of analysis by the U.S. Geological Survey National Water Quality Laboratory-Determination of organochlorine pesticides and polychlorinated biphenyls in bottom and suspended sediment by gas chromatography with electroncapture detection: U.S. Geological Survey Water-Resources Investigations Report 03-4293, 46 p.

Oberg, K.A., Morlock, S.E., and Caldwell, W.S., 2005, Quality-assurance plan for discharge measurements using Acoustic Doppler Profilers: U.S. Geological Survey Scientific Investigations Report 2005-5183, 35 p.

Omernik, J.M., 1987. Ecoregions of the conterminous United States: Association of American Geographers, v. 77, p. $118-125$.

Patton, C.J., and Kryskalla, J.R., 2011, Colorimetric determination of nitrate plus nitrite in water by enzymatic reduction, automated discrete analyzer methods: U.S. Geological Survey Techniques and Methods, book 5, chap. B8, 34 p.

Patton, C.J., and Truitt, E.P., 1992, Methods of analysis by the U.S. Geological Survey National Water Quality Laboratory - Determination of total phosphorus by a Kjeldahl digestion method and an automated colorimetric finish that includes dialysis: U.S. Geological Survey Open-File Report 92-146, 39 p.

Patton, C.J., and Truitt, E.P., 2000, Methods of analysis by the U.S. Geological Survey National Water Quality Laboratory-Determination of ammonium plus organic nitrogen by a Kjeldahl digestion method and an automated photometric finish that includes digest cleanup by gas diffusion: U.S. Geological Survey Open-File Report 00-170, 31 p.

Peck, A.M., and Hornbuckle, K.C., 2006, Synthetic musk fragrances in urban and rural air of Iowa and the Great Lakes: Atmospheric Environment, v. 40, p. 6101-6111.

Rabeni, C.F., Sarver, R.J., Wang, N., Wallace, G.S., Wieland, M., and Petersen, J.T., 1997, Biological criteria for streams of Missouri, 273 p., accessed December 2014 at $h t t p: / / d n r$. mo.gov/env/esp/docs/BiologicalCriteriaMUFinalReport.pdf.

Rantz, S.E., and others, 1982, Measurement and computation of streamflow: Volumes 1 and 2: U.S. Geological Survey Water-Supply Paper 2175, 284 p.

Rouse, K., 2004, Assessing urban wetlands (CD 997925010)-Final report to the U.S. Environmental Protection Agency: Missouri Department of Natural Resources, Geologic Survey and Resource Assessment Division, Water Resources Program, 21 p., accessed June 2014 at http://dnr. mo.gov/env/wrc/docs/urban-wetlands.pdf.
Sarver, R.J., 2003a, Semi-quantitative macroinvertebrate stream bioassessment: Jefferson City, Missouri, Missouri Department of Natural Resources, Air and Lands Protection Division, Environmental Services Program, 24 p., accessed December 2014 at http://oewri.missouristate.edu/assets/ OEWRI/MDNR_Semi-Quantitative_Macroinvertebrate_ Stream_Bioassessment_Project_Procedure.pdf.

Sarver, R.J., 2003b, Stream habitat assessment: Jefferson City, Missouri, Missouri Department of Natural Resources, Air and Lands Protection Division, Environmental Services Program, 40 p., accessed December 2014 at $h t t p: / / c p c b$. ku.edu/media/cpcb/datalibrary/assets/library/techdocs/ Streamhab2003Aug.pdf.

Sarver, R.J., 2005, Taxonomic levels for macroinvertebrate identifications: Jefferson City, Missouri, Missouri Department of Natural Resources, Air and Lands Protection Division, Environmental Services Program, 30 p., accessed December 2014 at $h t t p: / / c p c b . k u . e d u / m e d i a / c p c b /$ datalibrary/assets/library/techdocs/Taxlevels2005May.pdf.

Sarver, R.J., Harlan, Stuart, Rabeni, Charles, and Sowa, S.P., 2002, Biological criteria for wadeble/perennial streams of Missouri: Jefferson City, Missouri, Missouri Department of Natural Resources, Air and Lands Protection Division, Environmental Services Program, 47 p., accessed December 2014 at http://www.dnr.mo.gov/env/esp/docs/BiologicalCrite riaforWadeableStreamsofMissouri.pdf.

Schalk, G.K., 1993, Quantity and quality of base flow and stormwater runoff in Independence, Missouri-October 1991 to February 1993: U.S. Geological Survey Open-File Report 93-495, 69 p.

Senior, L.A., and Cinotto, P.J., 2007, Effect of on-site wastewater disposal on quality of ground water and base flow-A pilot study in Chester County, southeastern Pennsylvania, 2005: U.S. Geological Survey Open-File Report 2007$1253,50 \mathrm{p}$.

Seurinck, S., Defoirdt, T., Verstraete, W., and Siciliano, S.D., 2005, Detection and quantification of the human-specific HF183 Bacteroides 16S rRNA genetic marker with realtime PCR for assessment of human fecal pollution in freshwater: Environmental Microbiology, v. 7, no. 2, p. 249-259.

Shannon, C.E., and Weaver, W.W., 1949, The mathematical theory of communication: Urbana, Illinois, University of Illinois Press, $125 \mathrm{p}$.

Tennessen, K.J., 2008, Odonata in Merritt, R. W., Cummins, K.W., and Berg, M.B., eds., An introduction to the aquatic insects of North America (4th ed.): Kendall Hunt, Dubuque, Iowa, p. 237-294. 
Ternes, T.A., and Joss, A., eds., 2006, Human pharmaceuticals, hormones and fragrances-The challenge of micropollutants in urban water management: International Water Association Publishing, London, 472 p.

Turnipseed, D.P., and Sauer, V.B., 2010, Discharge measurements at gaging stations: U.S. Geological Survey Techniques and Methods, book 3, chap. A8, 87 p., accessed December 2014 at http://pubs.usgs.gov/tm/tm3-a8/.

U.S. Army Corps of Engineers, [2014], Longview/Blue Springs Lakes, Missouri brochure: accessed June 2014 at http://www.nwk.usace.army.mil/Portals/29/docs/lakesites/ Longview/Longview-Brochure.pdf.

U.S. Census Bureau, State and County QuickFacts, Independence (city), Missouri: accessed June 2014 http://quickfacts. census.gov/qfd/states/29/2935000.html.

U.S. Environmental Protection Agency, 1978, Method 420.1, Phenolics (Spectrophotometric, Manual 4-AAP with distillation): accessed June 2014, at http://water.epa.gov/scitech/ methods/cwa/bioindicators/upload/2007_07_10_methods_ method_420_1.pdf.

U.S. Environmental Protection Agency, 1983, Results of the nationwide urban runoff program: Final report, v. 1, accessed June 2014 at http://www.epa.gov/npdes/pubs/ sw_nurp_vol_1_finalreport.pdf.

U.S. Environmental Protection Agency, 1997, Guidelines establishing test procedures for the analysis of pollutants (App. B, Part 136, Definition and procedures for the determination of the method detection limit): U.S. Code of Federal Regulations, Title 40, revised July 1, 1997, p. 343-346, accessed June 2014 at http://www.gpo.gov/fdsys/ pkg/CFR-2012-title40-vol24/pdf/CFR-2012-title40-vol24part136-appB.pdf.

U.S. Environmental Protection Agency, 2000, Ambient water quality criteria recommendations: Rivers and streams in nutrient ecoregion IX, EPA 822-B-00-019, [variously paged], accessed June 2014, at http://water. epa.gov/scitech/swguidance/standards/criteria/nutrients/ upload/2007_09_27_criteria_nutrient_ecoregions_rivers_ rivers_9.pdf.

U.S. Environmental Protection Agency, 2014, National recommended water quality criteria, aquatic life criteria table, accessed December 2014 at http://water.epa.gov/scitech/ swguidance/standards/criteria/current/index.cfm.

U.S. Environmental Protection Agency, 2013, SW-846 Online: accessed June 2014, at http://www.epa.gov/epawastel hazard/testmethods/sw846/online/index.htm.
U.S. Geological Survey, 2004, Policy on the use of the Flow Tracker for discharge measurements: Office of Surface Water Technical Memorandum 2004.04, accessed June 2014 at http://hydroacoustics.usgs.gov/memos/OSW2004-04.pdf.

U.S. Geological Survey, 2006, National land cover database, accessed December 2014 at http://www.mrlc.gov/nlcd06 data.php.

U.S. Geological Survey, 2009, USGS water data for Missouri: accessed June 2014 at http://waterdata.usgs.gov/mo/nwis/ inventory/?site_no $=06894000 \& a \mathrm{mp}$.

U.S. Geological Survey, [variously dated], National field manual for the collection of water-quality data: U.S. Geological Survey Techniques of Water-Resources Investigations, book 9, chaps. A1-A9, accessed June 2014 at http://pubs.water. usgs.gov/twri9A.

U.S. Geological Survey National Water Quality Laboratory, 2014, Quality assurance, accessed October 2014 at http:// wwwnwql.cr.usgs.gov/USGS_Quality.shtml.

Wagner, R.J., Boulger, R.W., Jr., Oblinger, C.J., and Smith, B.A., 2006, Guidelines and standard procedures for continuous water-quality monitors - Station operation, record computation, and data reporting: U.S. Geological Survey Techniques and Methods, book 1, chap. D3, 51 p. plus 8 attachments, accessed June 2014 at http://pubs.water.usgs. gov/tm 1 d 3 .

Wilkison, D.H., Armstrong, D.J., and Blevins, D.W., 2002, Effects of wastewater and combined sewer overflows on water quality in the Blue River Basin, Kansas City, Missouri and Kansas, July 1998-October 2000: U.S. Geological Survey Water-Resources Investigations Report 02-4107, $62 \mathrm{p}$.

Wilkison, D.H., Armstrong, D.J., Brown, R.E., Poulton, B.C., Cahill, J.D., and Zaugg, S.D., 2005, Water quality and biologic data for the Blue River Basin, Kansas City Metropolitan Area, Missouri and Kansas, October 2000 to October 2004: U.S. Geological Survey Data Series Report 127, 158 p., accessed June 2014 at http://pubs.usgs.gov/ $d s / 2005 / 127 /$.

Wilkison, D.H., Armstrong, D.J., and Hampton, S.A., 2009, Water-quality and ecological trends and patterns in the Blue River Basin, Kansas City Metropolitan Area, Missouri and Kansas, 1998 to 2007: U.S. Geological Survey Scientific Investigations Report 2009-5169, 211 p.

Wilkison, D.H., Armstrong, D.J., Norman, R.D., Poulton, B.C., Furlong, E.T., and Zaugg, S.D., 2006, Water quality in the Blue River Basin, Kansas City Metropolitan Area, Missouri and Kansas, July 1998 to October 2004: U.S. Geological Survey Scientific Investigations Report 2006-5147, $170 \mathrm{p}$. 
Zaugg, S.D., Smith, S.G., and Schroeder, M.P., 2006, Determination of wastewater compounds in whole water by continuous liquid-liquid extraction and capillary-column gas chromatography/mass spectrometry: U.S. Geological Survey Techniques and Methods, book 5, chap. B4, 30 p.

Zaugg, S.D., Smith, S.G., Schroeder, M.P., Barber, L.B., and Burkhardt, M.R., 2002, Methods of analysis by the U.S.

Geological Survey National Water Quality LaboratoryDetermination of wastewater compounds by polystyrenedivinyl-benzene solid-phase extraction and capillarycolumn gas chromotography/mass spectrometry: U.S. Geological Survey Water-Resources Investigations Report 01-4186, $37 \mathrm{p}$. 

Appendixes 1 and 2 
Appendix 1. Base-flow water-quality sample results for selected physical and chemical properties and constituents, June 2006 through September 2013 (http://pubs.usgs.gov/ds/0915/ downloads/ds915_Appendix01.xlsx).
Appendix 2. Stormflow water-quality sample results for selected physical and chemical properties and constituents, June 2005 through September 2013 (http://pubs.usgs.gov/ds/0915/ downloads/ds915_Appendix02.xlsx).
Publishing support provided by: Rolla Publishing Service Center

For more information concerning this publication, contact: Director, Missouri Water Science Center U.S. Geological Survey 1400 Independence Road, MS-100 Rolla, MO 65401

(573) 308-3667

Or visit the Missouri Water Science Center Web site at: http://mo.water.usgs.gov/ 

